REGINA MEYER BRANSKI

O PAPEL DA TECNOLOGIA DA INFORMAÇÃO NO PROCESSO
LOGÍSTICO: ESTUDO DE CASOS COM OPERADORES LOGÍSTICOS

São Paulo 
REGINA MEYER BRANSKI

\title{
O PAPEL DA TECNOLOGIA DA INFORMAÇÃO NO PROCESSO LOGÍSTICO: ESTUDO DE CASOS COM OPERADORES LOGÍSTICOS
}

\author{
Tese apresentada à Escola \\ Politécnica da Universidade de \\ São Paulo para obtenção do título \\ de Doutor em Engenharia
}

São Paulo 


\section{O PAPEL DA TECNOLOGIA DA INFORMAÇÃO NO PROCESSO LOGÍSTICO: ESTUDO DE CASOS COM OPERADORES LOGÍSTICOS}

Tese apresentada à Escola

Politécnica da Universidade de

São Paulo para obtenção do título de

Doutor em Engenharia

Área de Concentração:

Engenharia de Produção

Orientador: Prof. Dr. Livre-Docente Fernando José Barbin Laurindo

\section{São Paulo}


Este exemplar foi revisado e alterado em relação à versão original, sob responsabilidade única do autor e com a anuência de seu orientador.

São Paulo, 28 de junho de 2008.

Regina Meyer Branski

$\overline{\text { Fernando José Barbin Laurindo }}$

\section{Ficha Catalográfica}

Branski, Regina Meyer

O papel da Tecnologia da Informação no processo logístico:

estudo de casos com operadores logísticos / R. M. Branski - São Paulo, 2008. Edição Revisada.

$252 \mathrm{p}$.

Tese (Doutorado) - Escola Politécnica da Universidade de São

Paulo. Engenharia de Produção.

1. Tecnologia de Informação 2. Logística

I. Universidade de São Paulo. Escola Politécnica

Departamento de Engenharia de Produção II. T. 
DEDICATÓRIA

Aos meus filhos, Tomás e Laura,

pelas horas roubadas. 


\section{AGRADECIMENTOS}

Muitas pessoas foram importantes para o desenvolvimento deste trabalho.

Agradeço a experiência e o conhecimento transmitidos pelo meu orientador, Professor Dr. Fernando José Barbin Laurindo.

Agradeço, enormemente, ao Professor Dr. Orlando Fontes Lima Jr. do Laboratório de Aprendizagem em Logística e Transporte (LALT) da UNICAMP. Seu apoio e confiança foram fundamentais para a conclusão da pesquisa.

Agradeço ao Professor Dr. Mário Possas, amigo de longa data, pelas conversas mesmo em seus momentos de lazer.

Agradeço a todos os meus amigos. $\mathrm{O}$ apoio emocional foi tão importante quando o acadêmico. 


\section{RESUMO}

O conceito de logística vem, ao longo do tempo, agregando novos elementos e tornando-se mais complexo. Nos anos 50 restringia-se à distribuição física. Atualmente engloba a totalidade dos fluxos de material, produtos e informação entre diferentes empresas da cadeia de suprimentos. Neste contexto, organizações dos mais variados segmentos vêm terceirizando suas operações logísticas para empresas especializadas denominadas operadores logísticos. As tecnologias de informação (TI) têm um importante papel no desenvolvimento das atividades logísticas e no desempenho dos operadores: suas aplicações permitem a otimização do sistema logístico e o gerenciamento de forma integrada de seus diversos componentes. $\mathrm{O}$ objetivo da pesquisa é investigar como a TI vem sendo utilizada pelos operadores nos processos logísticos e como vem contribuindo para o estabelecimento de redes de valor. A metodologia utilizada foi o estudo de casos múltiplos. Foram investigados cinco operadores logísticos com atuação no mercado brasileiro, com diferentes posicionamentos estratégicos, operando em diferentes setores e de modo a cobrir de forma integral o processo logístico. Os resultados da pesquisa indicaram a necessidade do desenvolvimento de aplicativos customizados, capazes de atender as particularidades de cada operador e de gerar vantagens competitivas, e apontaram a importância do papel da TI para o estabelecimento das redes de valor.

Palavras-chave: tecnologia da informação, processo logístico, gestão integrada da logística, operadores logísticos e redes de valor. 


\begin{abstract}
The logistics concept has been changing, adding new elements and becoming more complex. In the fifties it was restricted to physical distribution only. Nowadays, it embraces the total flow of materials, products and information between the different companies of a supply chain. In this new scenario, organizations in all industries have outsourced their logistics operations to specialized companies called logistics operators. Information technologies (IT) have an important role in the development of logistics activities and in the logistics operator's performance: IT applications allow an optimal tuning of the logistics system and an integrated management of its several components. The purpose of this research is to investigate how the logistics operators are applying IT in the logistics process and how IT is contributing to the establishment of value networks. The methodology utilized was the multiple cases study. Five logistic operators that feature different strategic positions and operate with different industries in the Brazilian market were investigated. The sample was chosen so as to provide the information needed for an analysis of all stages of the logistic process. The results of the research indicate that customized applications, suited to the particularities of each operator, play an important role in the creation of competitive advantages, and suggest the centrality of IT in the creation of value networks.
\end{abstract}

Keywords: Information technology, logistic process, integrated logistic management, logistic operators, and value networks 


\section{LISTA DE ILUSTRAÇÕES}

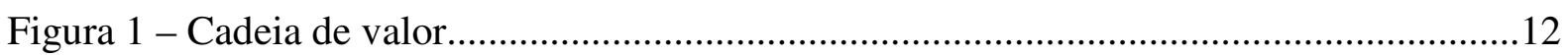

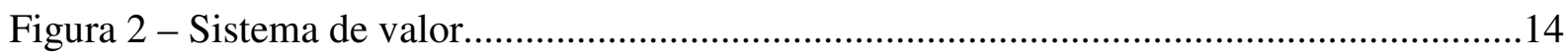

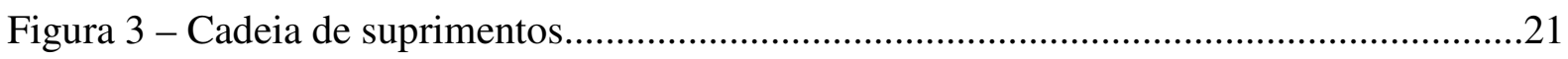

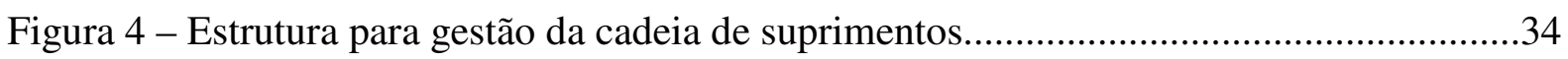

Figura 5 - Necessidades de informações logísticas ............................................................38

Figura 6 - Canais genéricos de distribuição....................................................................44

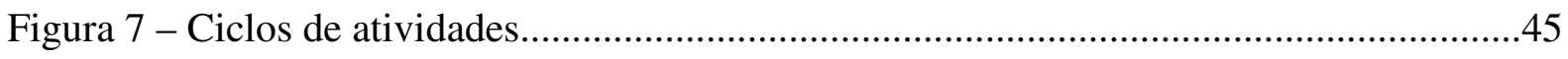

Figura 8 - Ciclos de atividades no processo logístico entre fornecedor e manufatura ............46

Figura 9 - Atividades da distribuição física ...................................................................47

Figura 10 - Atividades do ciclos de suprimentos ........................................................48

Figura 11 - Arquitetura da informação da empresa e infra-estrutura de TI ...........................69

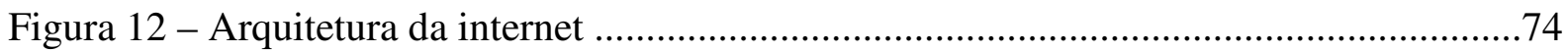

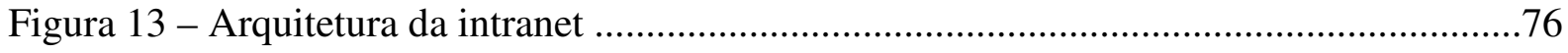

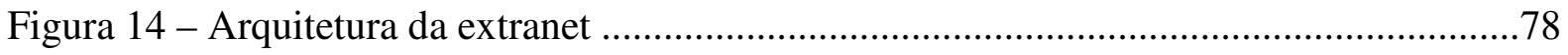

Figura 15 - Relação entre os sistemas de informação horizontais .......................................81

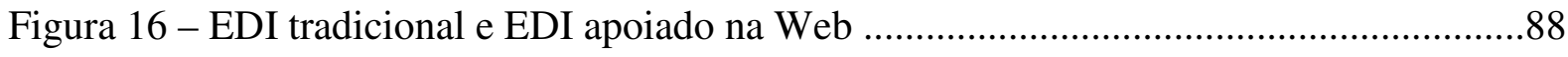

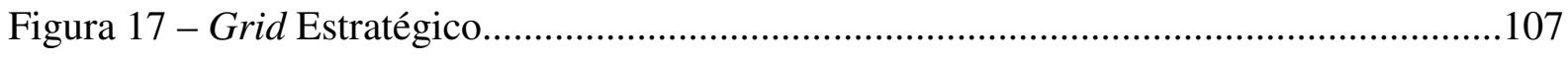

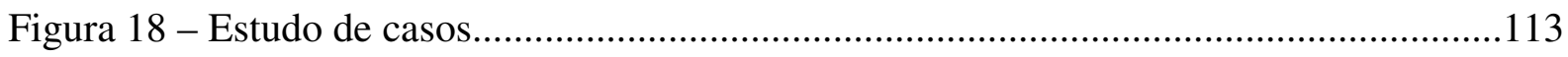

Figura 19 - Premissas e autores analisados (questão 1) ..................................................117

Figura 20 - Proposições e autores analisados (questão 2).................................................119

Figura 21 - Fluxo de materiais e produtos de OL 1 ..........................................................132

Figura 22 - Fluxo de informação do OL 1 ....................................................................134

Figura 23 - Fluxo de materiais e produtos do OL2 - fast-food ..........................................144

Figura 24 - Fluxo de Informação de OL 2 ….............................................................. 148

Figura 25 - Fluxos de materiais e produtos de OL 3 ........................................................156 


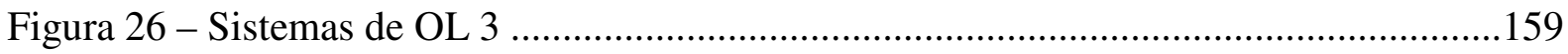

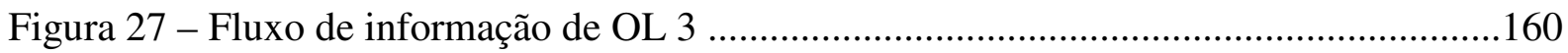

Figura 28 - Processo logístico do OL 4 Supply Chain .........................................................168

Figura 29 - Fluxo de informação do OL 4 Supply Chain .....................................................171

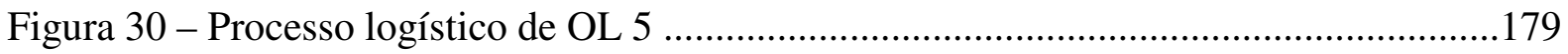

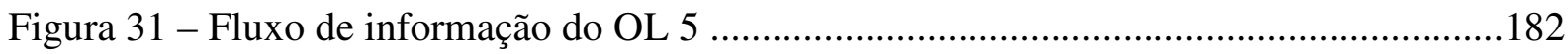

Figura 32 - Integração entre operadores e outros agentes da rede.....................................216

Figura 33 - Agentes e níveis de integração externa dos operadores estudados.....................219 


\section{LISTA DE QUADROS}

Quadro 1 - Estágios de integração para a gestão da cadeia de suprimentos.

Quadro 2 - Relação entre fatores negativos e os objetivos da SCM.

Quadro 3 - Atividades operacionais nas áreas de suprimentos, apoio à manufatura e

distribuição.

Quadro 4 - Influência do posicionamento estratégico sobre as estruturas. 80

Quadro 5 - Sistemas de informação verticais e funções. 103

Quadro 6 - Características das perspectivas de alinhamento estratégico. 106

Quadro 7 - Caracterização dos operadores logísticos. 190

Quadro 8 - TI no processo logístico. .195

Quadro 9 - TI no estabelecimento das redes de valor. 198

Quadro 10 - Principais resultados (Proposições 1, 2 e 3). .206

Quadro 11 - Principais resultados (Proposição 4). 


\section{LISTA DE ABREVIATURAS E SIGLAS}

3PL - Third-party logistics providers

4PL - Fourth-Party Logistics

ABML - Associação Brasileira de Movimentação e Logística

$\mathrm{BI}$ - Business Intelligence

CA - Centro de Apoio

CD - Centro de Distribuição

CEL - Centros Expressos de Logística

CEP - Centros Estratégicos de Peças

CPFR - Collaborative Planning, Forecasting and Replenishment

CR - Continuous Replenishment

CRM - Customer Relationship Management Systems

CRTC - Conhecimento Rodoviário de Transporte de Cargas

CSCMP - Council of Supply Chain Management Professionals

DDE - Declaração para Despacho de Exportação

DI - Declaração de importação

DMMS - Database Management Systems

DPR - Distribution Requirement Planning

DSS - Decision Support Systems

ECR - Efficient Consumer Response

EDI - Electronic Data Interchange

EDI - Electronic Data Interchange

EES - Executive Support System

ERP - Enterprise Resource Planning

FIFO - First In, First Out 
FTP - File Transfer Protocol

GEL - Gestão Estruturada da Logística

GIS - Geographic Information Systems

GPS - Geo-positioning Systems

INCOTERMS - International Commercial Terms

IOS - Information Organization Systems

IP - Internet Protocol

JIT - Just in time

KMS - Knowledge Management System

LAN - Local Área Network

LIFO - Last In, First Out

MIS - Management Information Systems

MRP - Materials Requirements Planning

MRP II - Manufacturing Resources Planning

OL 1 - Operador Logístico 1

OL 2 - Operador Logístico 2

OL 3 - Operador Logístico 3

OL 4 - Operador Logístico 4

OL 5 - Operador Logístico 5

PPR - Programas de Resposta Rápida

PROLOGS - Projeto Logístico

PSL - Prestador de Serviço Logístico

QR - Quick Response

RDIF - Radio Frequency Identification

RE - Registro de Exportação

RFF - Rede Fast Food 
RFP - Request for Proposal

SCM - Supply Chain Management

SFL - Sistema Fiscal Logístico

SI - Sistemas de Informação

SIL - Sistemas de Informação Logísticos

SISCOMEX - Sistema Integrado de Comércio Exterior

TCP - Transmission Control Protocol

TI - Tecnologia de Informação

TMS - Transportation Management Systems

TPS - Transaction Processing Systems

VAN - Vallue Added Network

VMI - Vendor Managed Inventory

VPN - Virtual Private Network

WAN - Wide Área Network

WMS - Warehouse Management System 


\section{SUMÁRIO}

INTRODUÇÃO, OBJETIVOS E JUSTIFICATIVA..........................................................1

\section{CAPÍTULO 1 - ESTRATÉGIA, REDES DE EMPRESA E REDES DE VALOR ...........8}

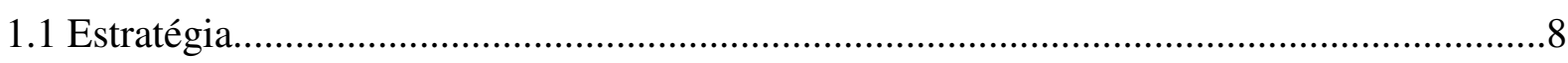

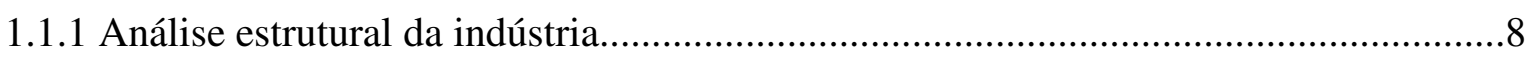

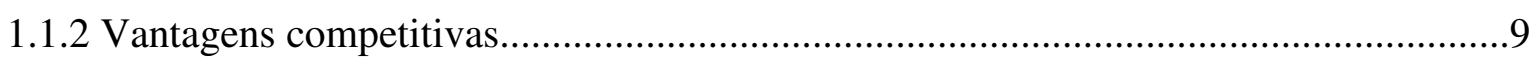

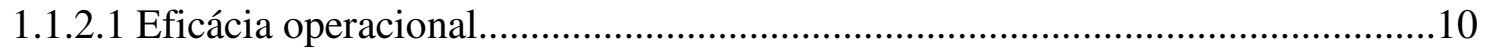

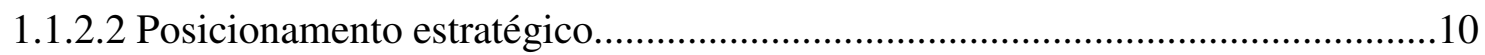

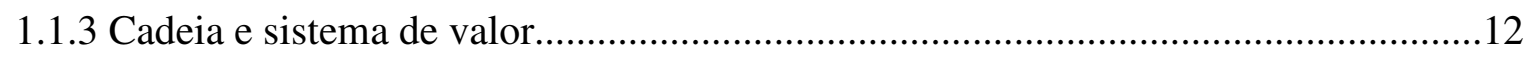

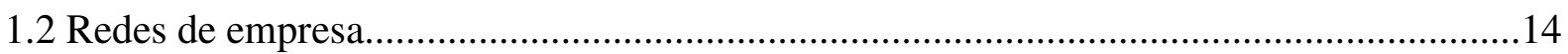

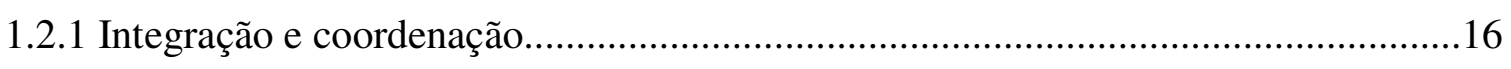

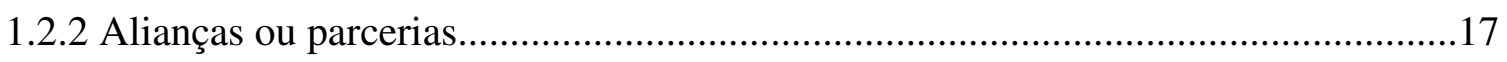

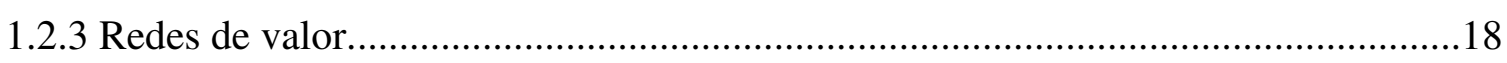

\section{CAPÍTULO 2 - CADEIA DE SUPRIMENTOS E SUPPLY CHAIN MANAGEMENT...20}

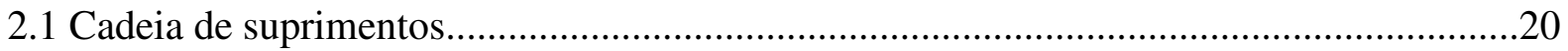

2.1.1 Dinâmica de operação da cadeia de suprimentos.....................................................22

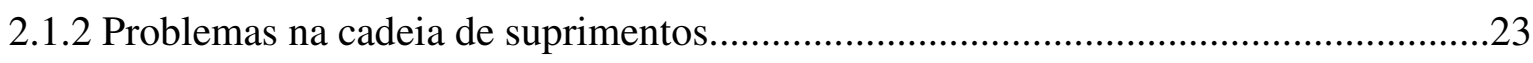

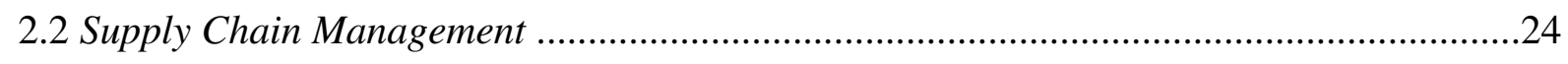

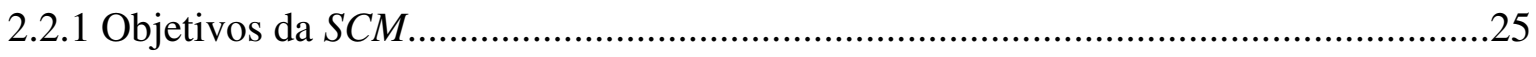

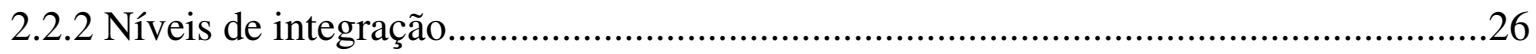

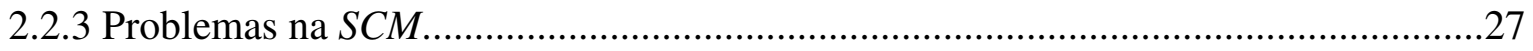

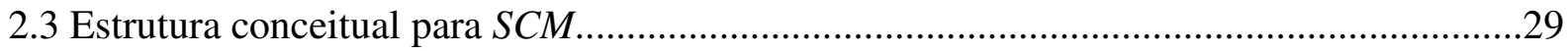

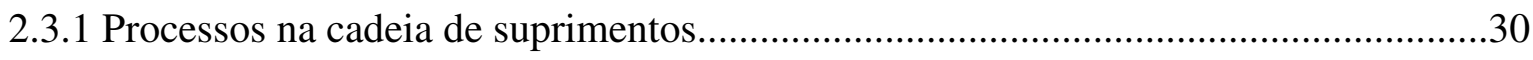

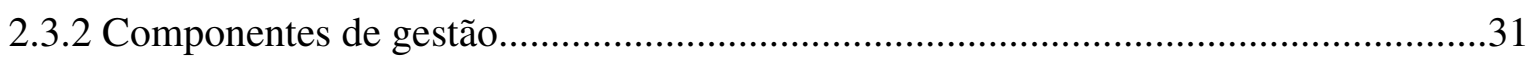

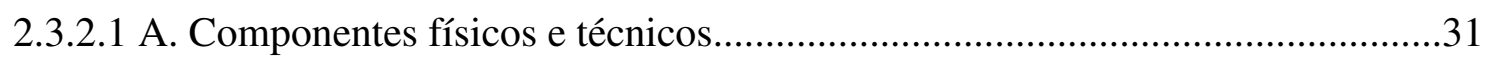

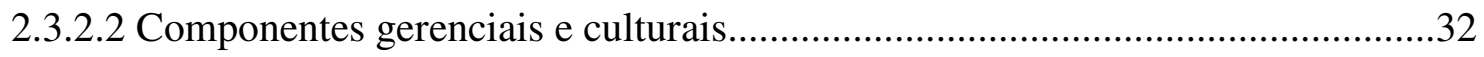

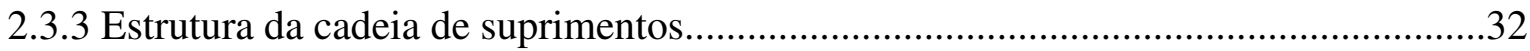


CAPÍTULO 3 - LOGÍSTICA E LOGÍSTICA INTEGRADA.............................................36

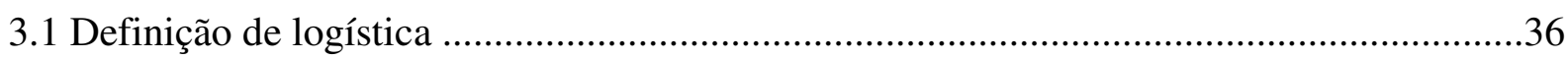

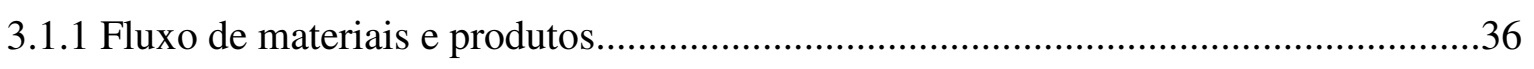

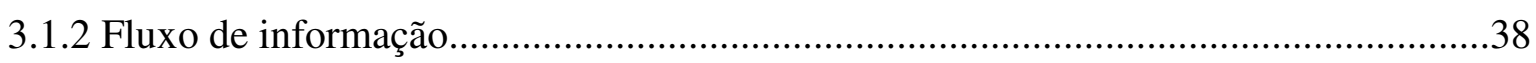

3.1.2.1 De planejamento e coordenação............................................................................39

3.1.2.2 Operacional.................................................................................................

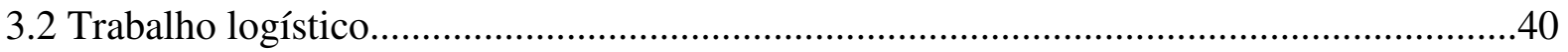

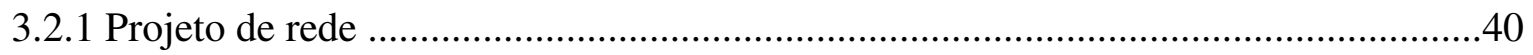

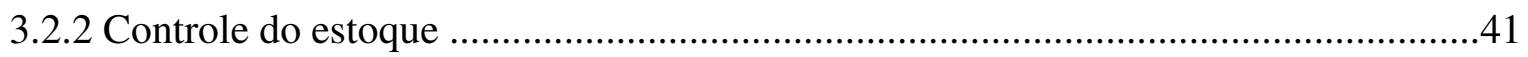

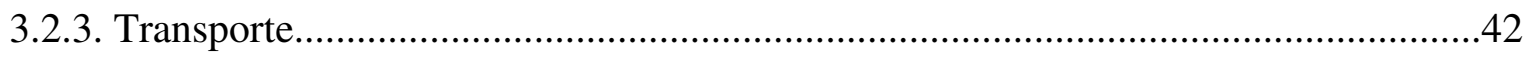

3.2.4 Armazenagem, manuseio de materiais e embalagem................................................42

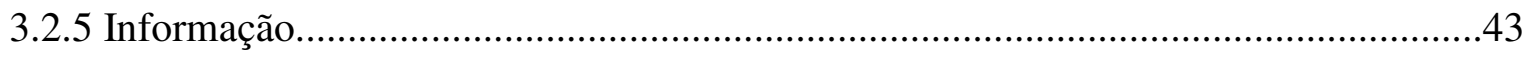

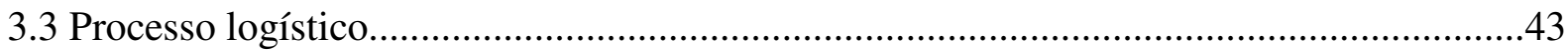

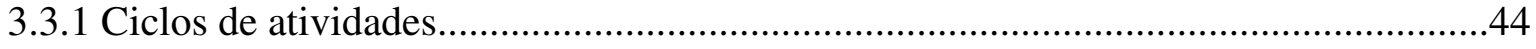

3.3.1.1 Ciclos de atividades da distribuição física.........................................................46

3.3.1.2 Ciclos de atividades de apoio à manufatura.........................................................47

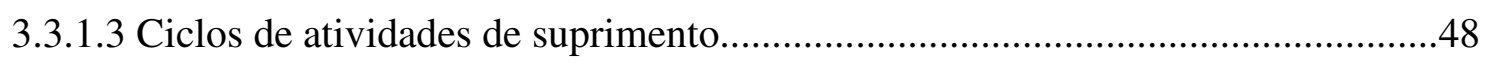

3.3.2 Ciclos de atividades globais................................................................................4

3.3.3 Semelhanças e diferenças entre os ciclos de atividades...............................................50

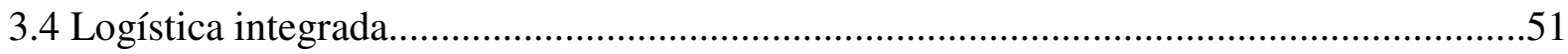

CAPÍTULO 4 - OPERADORES LOGÍSTICOS................................................................53

4.1 Terceirização das atividades Logísticas..........................................................................53

4.2 De operadores logísticos (3PLs) a integradores logísticos.................................................54

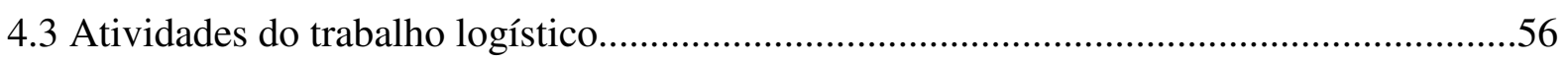

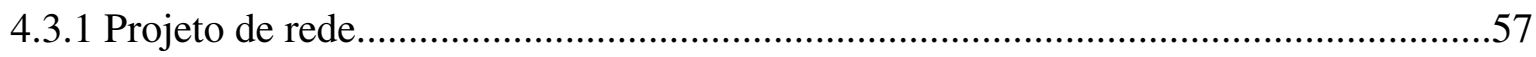

4.3.2 Armazenagem, manuseio e embalagem.................................................................57

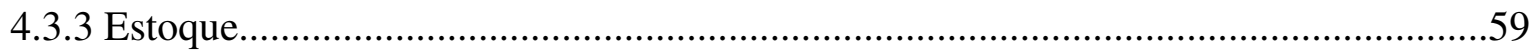

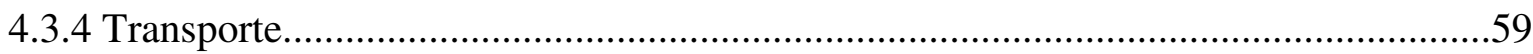

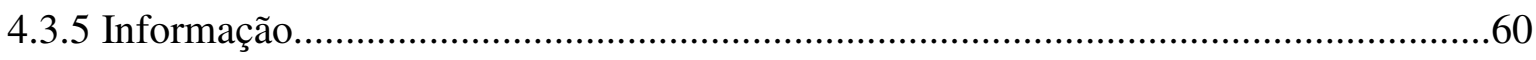

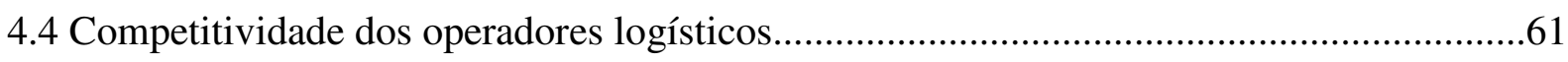

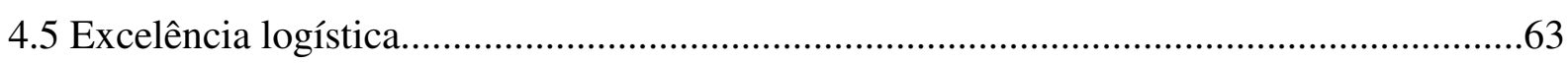




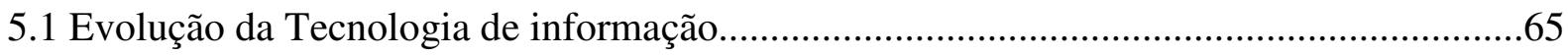

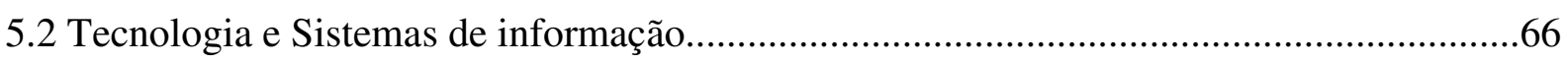

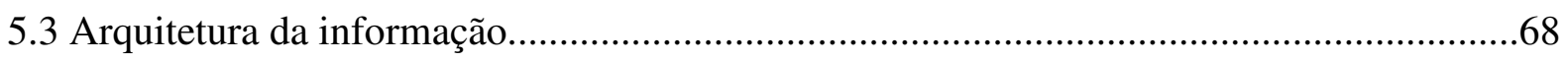

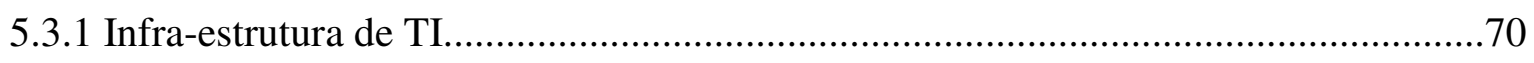

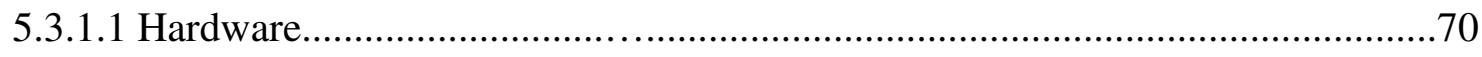

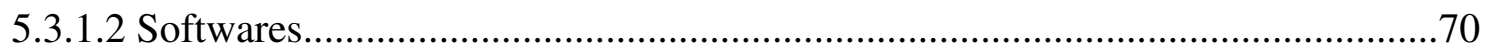

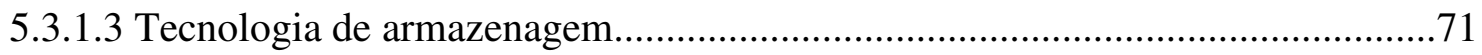

5.3.1.4 Redes de comunicação........................................................................... 72

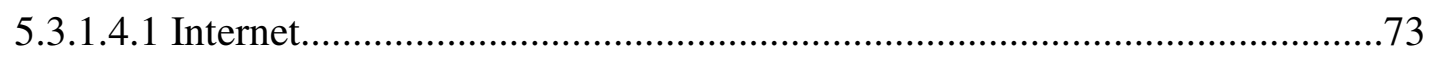

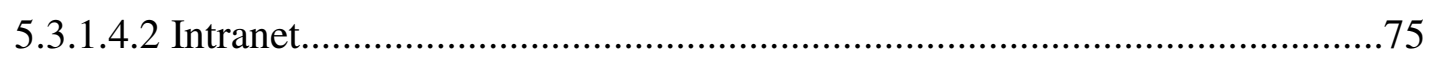

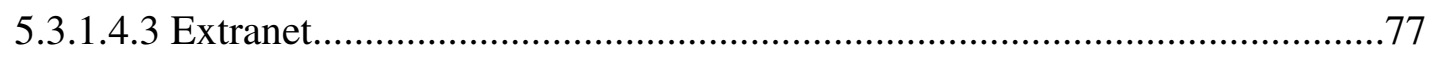

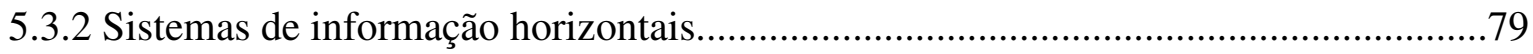

5.3.2.1 Relações entre os sistemas de informação horizontais........................................80

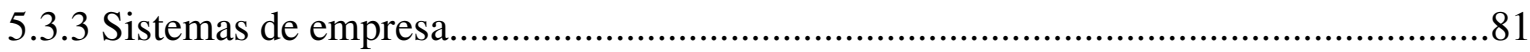

5.3.3.1 Sistemas Integrados de Gestão (Enterprise Resource Planning - ERP).............82

5.3.3.2 Gestão da cadeia de suprimentos e Negócios colaborativos.................................84

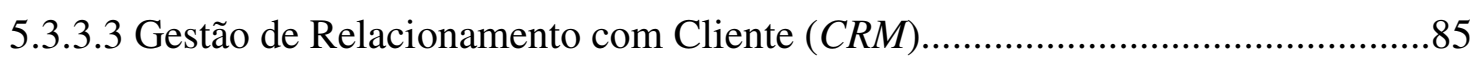

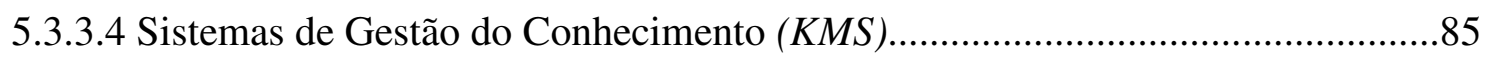

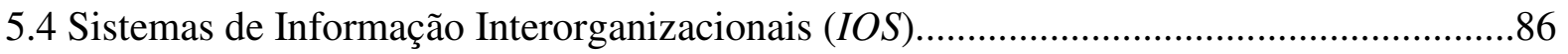

5.4.1 Intercâmbio eletrônico de dados (Electronic Data Interchange - EDI)......................86

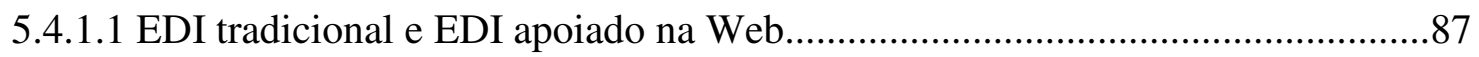

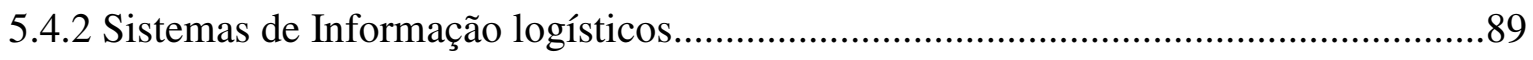

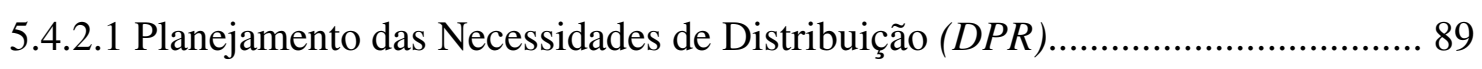

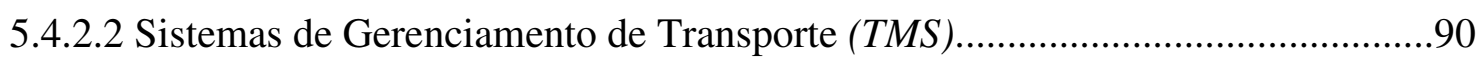

5.4.2.3 Sistemas de Gerenciamento de Armazéns (WMS)...........................................90

5.4.2.4 Sistemas de Informação Geográfica $($ GIS)........................................................91

5.4.2.5 Sistemas de Geo-posicionamento (GPS).......................................................91

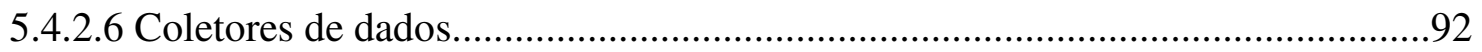

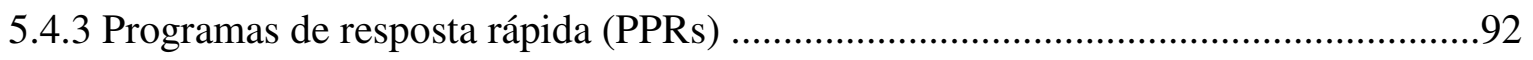

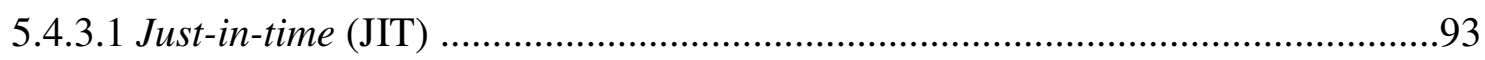

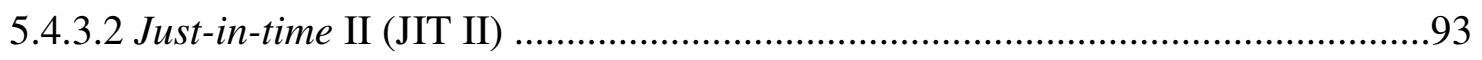

5.4.3.3 Planejamento das Necessidades de Material (MRP)........................................94

5.4.3.4 Planejamento dos Recursos de Produção (MRPII) ............................................94 
5.4.3.5 Resposta Rápida (Quick Response - QR).....................................................95

5.4.3.6 Reabastecimento Contínuo (Continuous Replenishment - CR) .........................95

5.4.3.7. Resposta Eficiente ao Consumidor $(E C R)$......................................................95

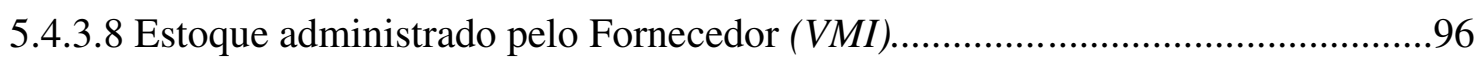

5.4.3.9 Planejamento colaborativo, previsão e reabastecimento (CPFR). .....................97

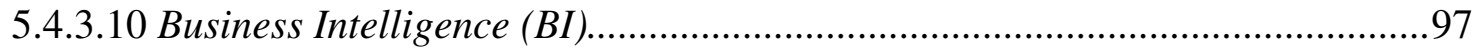

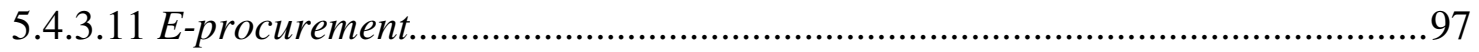

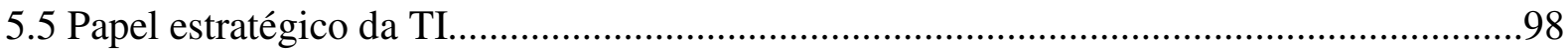

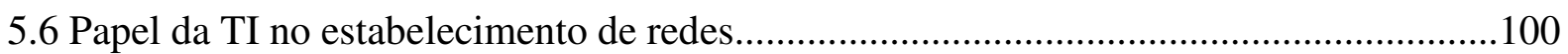

5.7 Relação entre TI e estratégia, metas, estrutura interna e estrutura

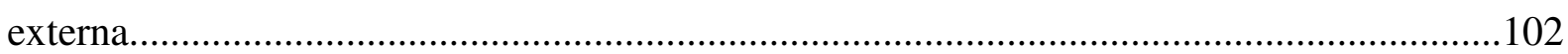

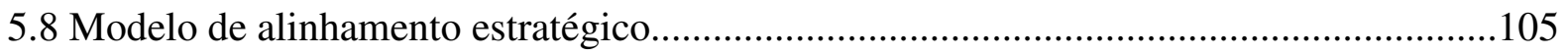

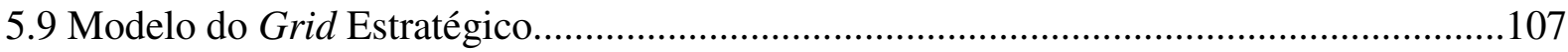

CAPÍTULO 6 - METODOLOGIA.....................................................................................109

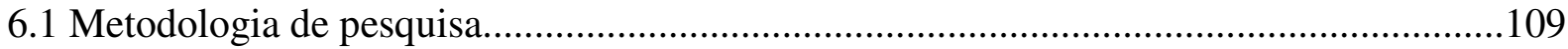

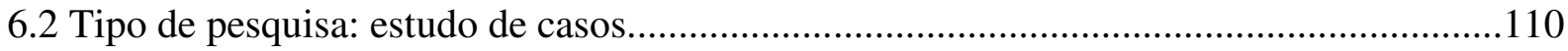

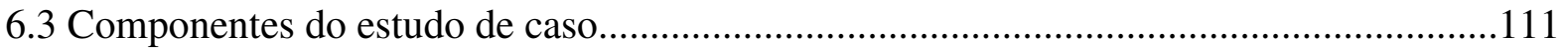

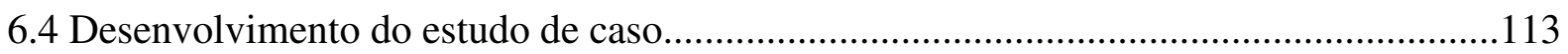

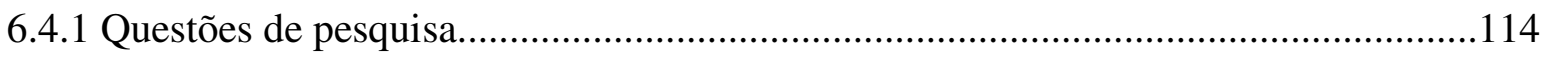

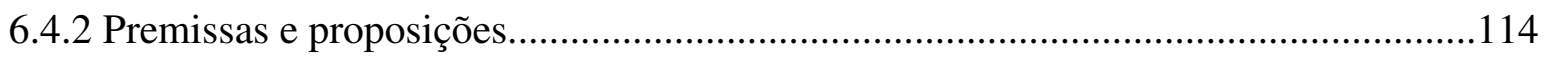

6.4.3 Unidades de análise: operadores logísticos..........................................................117

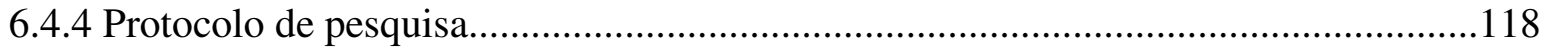

6.4.4.1 Coleta e tratamento dos dados......................................................................... 118

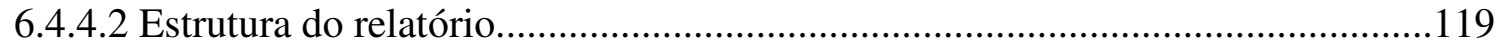

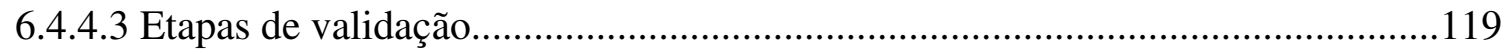

6.4.4.4 Ligação dos dados à proposição e critérios para a interpretação dos dados.......120

6.4.5 Limitações do Método........................................................................................... 120

CAPÍTULO 7 - INDÚSTRIA LOGÍSTICA E ESTUDO DE CASOS...............................124

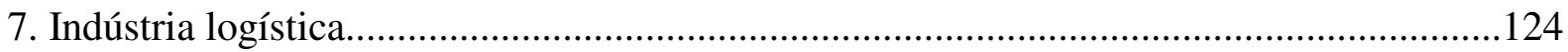

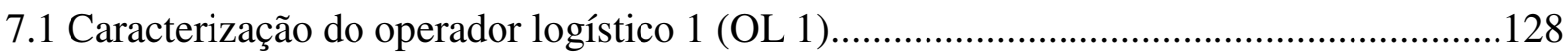

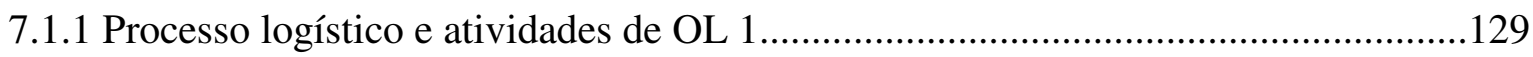


7.1.2 Fluxo de informação e TI no OL 1

7.1.3 Análise do papel da TI no apoio as atividades desenvolvidas

7.1.4 TI e a gestão integrada da logística.

7.2 Caracterização do operador logístico 2 (OL 2)............................................................139

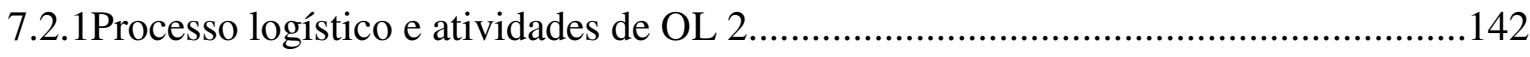

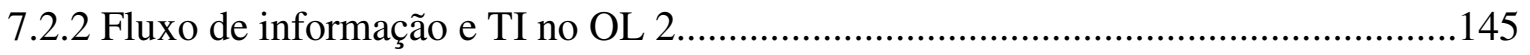

7.2.3 Análise do papel da TI no apoio as atividades desenvolvidas.................................150

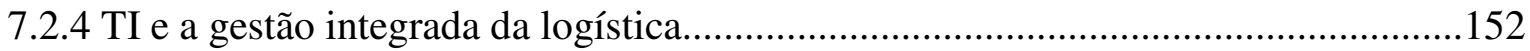

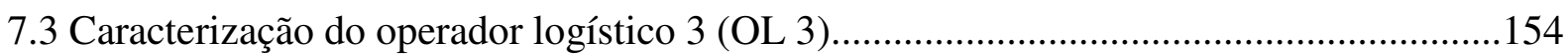

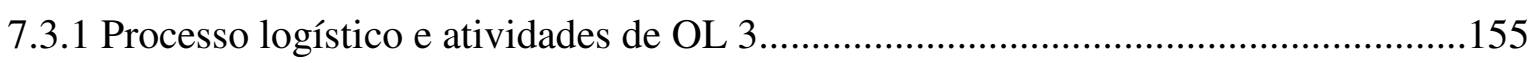

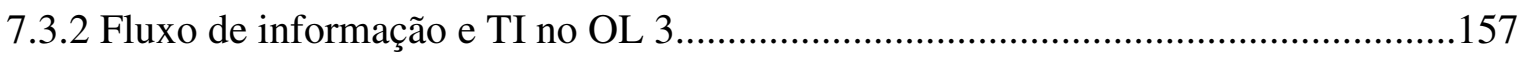

7.3.3 Análise do papel da TI no apoio as atividades desenvolvidas.................................161

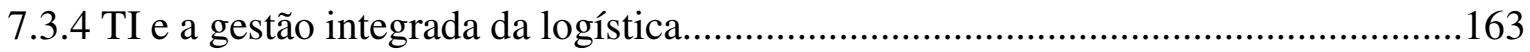

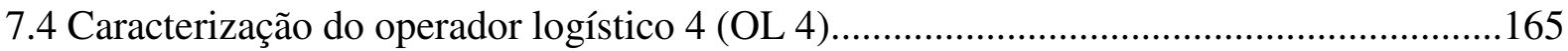

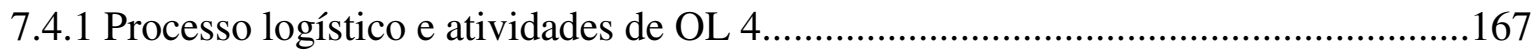

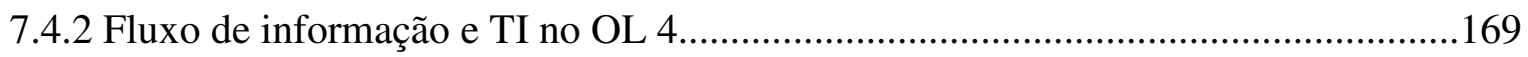

7.4.3 Análise do papel da TI no apoio as atividades desenvolvidas..................................172

7.4.4 TI e a gestão integrada da logística........................................................................ 175

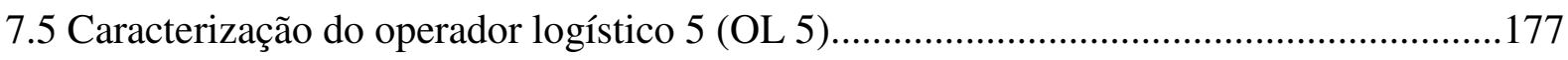

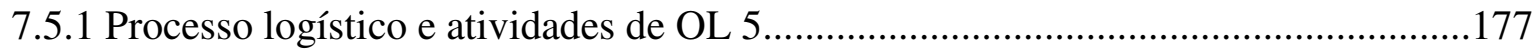

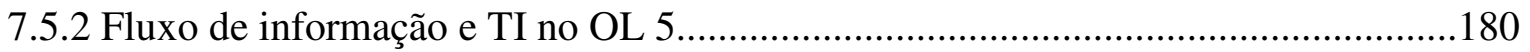

7.5.3 Análise do papel da TI no apoio as atividades desenvolvidas...............................185

7.5.4 TI e a gestão integrada da logística........................................................................ 187

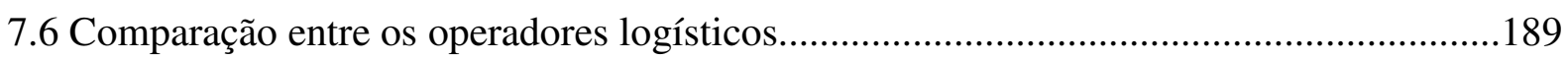

7.6.1 Caracterização dos operadores logísticos..............................................................190

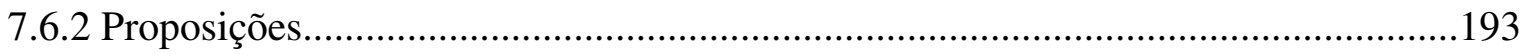

7.6.2.1 Processo logístico e atividades dos operadores................................................198

7.6.2.2 Fluxo de informação e TI nos operadores.......................................................199

7.6.2.3 Análise do papel da TI no apoio as atividades desenvolvidas........................200

7.6.2.4 A TI como base da gestão integrada da logística ..........................................203

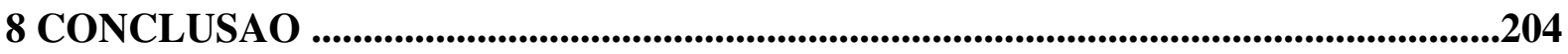

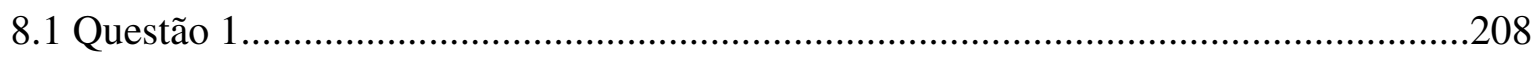

8.1.1 Análise da Proposição 1................................................................................210 


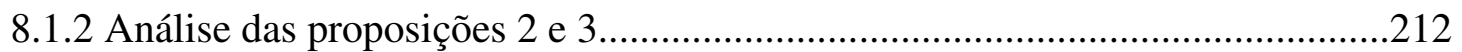

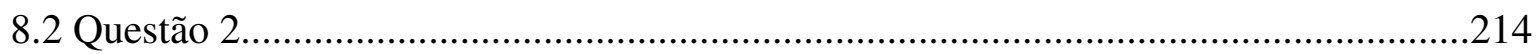

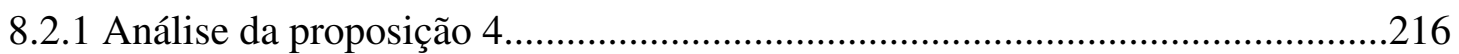

8.3 Proposta de um modelo para identificação dos níveis de integração externa...............218

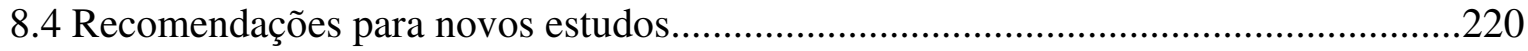

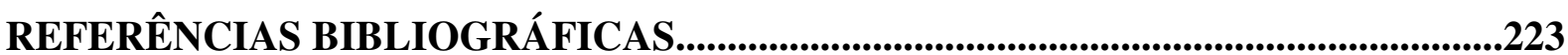

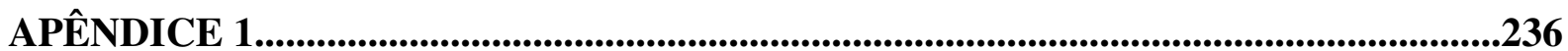

APÊNDICE 2 


\section{INTRODUÇÃO}

Desde o início dos 80, e mais intensamente nos anos 90, a visão empresarial sobre logística vem mudando. Um número crescente de empresas vem considerando a logística não como uma atividade operacional, um centro de custos, mas como atividade estratégica, uma ferramenta gerencial, fonte potencial de vantagem competitiva (FLEURY, 2000).

Logística é a parte do processo da cadeia de suprimentos que planeja, estabelece e controla os fluxos e estoques de matéria prima, produtos intermediários e acabados, serviços e informação desde a origem até o consumidor final (Council of Supply Chain Management Professionals).

Cadeia de suprimentos é o conjunto das organizações, recursos e atividades conectados e comprometidos com a criação, distribuição e venda de produtos acabados e serviços para o consumidor final. Envolve fornecedores de matéria-prima, plantas produtivas, centros de distribuição, varejistas, estoque em trânsito e produtos acabados. Inclui, ainda, o fluxo de informações de e para todos os agentes participantes (TURBAN; LEE; KING; CHUNG; 2002).

A crescente importância estratégica da logística decorre, sobretudo, das mudanças gerais que vem ocorrendo no ambiente dos negócios e que, progressivamente, estão contaminando as empresas e suas formas de operar. Para Rainbird (2004), há mudanças nos:

- Mercados: maior instabilidade do consumidor, elevada competição e incerteza, modismos, exigência por maior qualidade e serviços.

- Fatores estruturais: saturação e alta competitividade, aumento do poder dos compradores, diminuição do ciclo de vida dos produtos, baixa lucratividade, altas taxas de mudanças tecnológicas e a ampliação dos canais alternativos de distribuição.

- Foco: empresas estão mais voltadas para as redes de negócio e menos para as organizações individuais. As redes operam como uma única organização, buscando o melhor para o sistema como um todo.

Para enfrentar este ambiente de negócios cada vez mais complexo, o conceito de logística foi evoluindo ao longo do tempo, agregando elementos e tornando-se mais amplo. Nos anos 50 restringia-se à distribuição física. Na década de 70 incluiu a administração de materiais e suprimentos. A partir do final dos anos 70, a movimentação e armazenagem desde a aquisição de matéria prima até o consumo final. Atualmente o conceito engloba a totalidade 
dos fluxos de material e informação e, portanto, abrange as ligações entre diferentes empresas da cadeia de suprimentos.

$\mathrm{Na}$ base da ampliação do conceito de logística estão as possibilidades abertas pelo desenvolvimento tecnológico, com especial destaque para as Tecnologias de Informação (TI) (MCFARLAN, 1984; BOVET; MARTHA, 2001; COOPER, 1993; FLEURY; WANKE; FIGUEIREDO, 2000; BALLOU, 2007). Por TI entende-se às várias tecnologias convergentes e vinculadas que processam as informações que as empresas criam e utilizam. "Assim envolve, além de computadores, equipamentos de reconhecimento de dados, tecnologias de comunicações, automação de fábricas e outras modalidades de hardware e de serviços" (PORTER, 1999, p. 83).

A evolução da TI vem caminhando no sentido da diminuição no custo dos equipamentos, maior capacidade de processamento e softwares cada vez mais sofisticados. Este poder crescente dos computadores e aplicativos foi potencializado pelo desenvolvimento das telecomunicações que permitiu que as informações, processadas e armazenadas nos computadores, pudessem ser transmitidas entre as empresas por meio de redes (LAUDON; LAUDON, 2004; APPLEGATE, AUSTIN; MCFARLAN, 2003).

As possibilidades abertas pelo desenvolvimento da TI tornaram possível a integração e coordenação dos canais que coletam, transmitem e processam as informações e os canais físicos, como transportadoras, centros de distribuição, plantas industriais, etc. (LEWIS; TALALAYEVSKY, 2000). Por meio da integração, as informações podem ser compartilhadas entre os agentes. E, por meio da coordenação, as atividades e agentes da cadeia podem operar de forma sincronizada, como uma única organização (BOWERSOX; CLOSS, 2001; ASSUMPÇÃO, 2003; TURBAN; RAINER; POTTER, 2003).

A administração dos fluxos e estoques como um processo, integrando e coordenando as diversas atividades operacionais e priorizando a eficiência da cadeia como um todo foi denominada gestão integrada da logística. O paradigma fundamental da gestão logística é que o desempenho integrado produz melhores resultados que funções gerenciadas individualmente, sem coordenação entre si (RUTNER; LANGLEY, 2000).

A TI está, portanto, na base da gestão integrada da logística, oferecendo infra-estrutura de apoio e os diversos aplicativos que possibilitam a integração e coordenação dos agentes da cadeia, permitindo que as diferentes empresas possam operar como uma única organização (LAUDON; LAUDON, 2004).

Mas, o papel da TI vai além. A sincronização das atividades e o estabelecimento de fluxos contínuos, sem interrupções ou falhas, que resultam da integração e coordenação dos 
processos entre os agentes, permitem a racionalização das tarefas, a diminuição da necessidade de estoques e o aprimoramento dos serviços oferecidos aos clientes (BOWERSOX; CLOSS, 2001; CHANDRASHEKAR; SCHARY, 1999; ASSUMPÇÃO, 2003). Assim, além de ferramenta de apoio, a TI tem também grande potencial para agregar valor aos produtos e processos, gerando vantagens competitivas (WILLIAMS; NIBBS; IRBY, 1997; PORTER, 1999). A TI é, portanto, importante arma estratégica, contribuindo para o desempenho das empresas e da rede como um todo.

Diante da crescente complexidade da logística e da sofisticação e difusão das tecnologias, organizações dos mais variados setores vêm terceirizando suas operações logísticas para prestadores de serviços. Prestador de serviço logístico (PSL) é um agente que executa atividades logísticas para outras empresas (LEWIS; TALALAYEVSHY; 2000).

O termo prestador de serviços é uma denominação genérica que se aplica a qualquer empresa que preste algum tipo de serviço logístico. Inclui, portanto, desde simples agentes de transporte até empresas capazes de atuar na gestão integrada da logística. Entre um extremo e outro existem prestadores com níveis de sofisticação variados.

Os prestadores de serviços logísticos que atuam na integração logística vêm sendo denominados, pela literatura internacional, third-party logistics providers ( $3 P L)$, enquanto no Brasil, vem predominando o uso do termo operador logístico.

Na gestão integrada da logística, os operadores atuam como intermediário, integrando e coordenando os fluxos e estoques de materiais, produtos e informação entre as diferentes organizações. Alinham os processos operacionais de várias empresas, dentro de um sistema de cadeias de suprimentos integradas, constituindo uma rede (LEWIS; TALALAYEVSKY, 2000).

Para enfrentar a crescente complexidade, a estratégia adotada por estes agentes vem sendo - de forma geral - o estabelecimento de parcerias com outros operadores e prestadores de serviços logísticos. Por meio do estabelecimento de parcerias e de fusões e aquisições estes agentes ampliam seu mercado de atuação, o escopo de suas atividades e sua capacidade de oferecer serviços com maior valor agregado (FLEURY; WANKE; FIGUEIREDO, 2000; BOLUMOLE, 2001).

O desempenho dos operadores logísticos depende, portanto, da capacidade de gerenciamento operacional e estratégico dos processos e da gestão da informação e do conhecimento entre diferentes agentes da cadeia. Consequentemente exige utilização intensiva da TI (FLEURY; WANKE; FIGUEIREDO, 2000; BOLUMOLE, 2001). 
É por meio da TI que estes agentes são capazes de partilhar dados e outras informações e coordenar suas atividades com as de seus parceiros, clientes e demais agentes da cadeia. A TI fornece ferramentas de apoio para integração e coordenação dos processos logísticos e para estabelecimento de parcerias, constituindo a base para a gestão integrada dos processos logísticos e, conseqüentemente, para o desenvolvimento das atividades dos operadores (CHOPRA; MEINDL, 2001).

\section{Objetivos da pesquisa}

Os objetivos da pesquisa são: compreender como a TI vem sendo utilizada pelos operadores no processo logístico e como vem contribuindo para o estabelecimento das redes de valor.

Para atingir o primeiro objetivo é necessário identificar os fluxos de materiais, produtos e informação entre os agentes da cadeia, os aplicativos de TI em cada área do trabalho logístico e, dentro de cada área, nas diversas atividades. Em seguida, analisar o papel dos aplicativos no desenvolvimento do processo logístico pelo operador e no atendimento às necessidades dos clientes.

Para o segundo objetivo é necessário investigar os níveis de integração existente entre os agentes, a existência ou não de coordenação dos fluxos de materiais, produtos e informação e o estabelecimento de parcerias.

\section{Justificativa}

A escolha dos operadores logísticos como objeto da pesquisa justifica-se porque:

- Há consenso entre as empresas quanto ao papel estratégico desempenhado pela logística e, conseqüentemente, pelos operadores logísticos (WILLIAMS et al.,1997).

- Atuam nos processos externos, ligando as empresas à seus parceiros de negócio. A integração e coordenação dos elos entre empresas são fundamentais para o aprimoramento do desempenho global da rede e onde estão as maiores oportunidades para o estabelecimento de vantagens competitivas (PORTER, 1985).

- Por meio dos operadores é possível analisar os processos logísticos em diferentes setores, analisando suas especificidades. 
- As atividades logísticas utilizam e geram um grande volume de informação que deve ser processada e transmitida ao longo das redes. Assim, a informação e, portanto, a TI, são centrais para o desenvolvimento das atividades logísticas e dos operadores.

- E, finalmente, como aponta a pesquisa realizada por Maloni e Carter (2006), são necessários estudos que explorem a relação entre os operadores e entre operadores e usuários de serviços logísticos, monitorando elementos, identificando correlações e abordando tópicos específicos como, no caso desta tese, a TI.

Maloni e Carter (2006) realizaram ampla revisão dos estudos existentes sobre os operadores logísticos com o objetivo de apontar oportunidades de pesquisa na área. Dividiram as áreas de pesquisa em dois blocos: foco nos usuários de serviços logísticos e foco nos operadores logísticos.

Nas pesquisas com foco nos usuários de serviços logísticos foram encontrados, de forma recorrente, tópicos como: funções da terceirização, razões para terceirizar, fatores de sucesso e dificuldades no relacionamento com operadores, desempenho e satisfação na relação com operadores e elementos contratuais.

Dentre estes trabalhos, Maloni e Carter (2006) destacam: Sauvage (2003) e Bhatanagar e Viswanathan (1999) que discutem os determinantes do sucesso na terceirização; Park e Kim (2002), os fatores que afetam a escolha dos operadores e; Bolumole (2001), os fatores que influenciam na decisão de terceirizar a logística e implicações estratégicas para a cadeia de suprimentos.

Nos trabalhos com foco nos operadores logísticos, Maloni e Carter (2006) destacam: Wanke (2004) estuda a crescente sofisticação das atividades dos operadores e sua importância para a terceirização; Lemoine e Dagnaes (2003) abordam a dinâmica da internacionalização e globalização dos operadores logísticos; Lieb e Randall (1996) pesquisam os produtos e serviços oferecidos pelos operadores; e Anderson (1997) e Berglund (1998) as demandas e graus de integração com clientes.

Maloni e Carter (2006) concluem que:

- A maioria dos trabalhos existentes (cerca de 2/3) tem como foco os usuários dos serviços logísticos. Trabalhos explorando as questões a partir do ponto de vista dos operadores são em número bem inferior e, em menor número ainda, os que abordam a relação entre operadores e entre operadores e usuários de serviços logísticos. Os autores apontam a necessidade do desenvolvimento de pesquisas com foco nos operadores e, sobretudo, abordando a interação entre grupos de empresas e entre operadores e usuários. 
- Os trabalhos fornecem, de forma geral, uma visão ampla do setor logístico, sendo que menos de $10 \%$ estavam voltados para uma indústria em particular ou para o desenvolvimento de serviços logísticos específicos. Há, portanto, necessidade de desenvolvimento de estudos de caso e trabalhos conceituais que abordem tópicos relevantes, tais como uso da tecnologia e consolidação dos operadores.

- Grande parte das pesquisas está voltada para o mercado americano. Há, portanto, necessidade de ampliar escopo geográfico dos estudos, se possível abordando múltiplas regiões simultaneamente. Para os autores, a identificação de similaridades e diferenças entre os operadores ajuda a identificar as melhores práticas.

- Finalmente, apontam a necessidade de limitar o escopo da investigação para uma população mais estreita e/ou controlar os elementos para aumentar a validade da pesquisa. Elementos como características da indústria, particularidades dos produtos, estratégias, etc., podem afetar o resultado da pesquisa.

As conclusões de Maloni e Carter (2006) também podem ser verificadas no caso brasileiro. A maior parte das pesquisas está focada nos usuários de serviços logísticos fornecendo, de forma geral, uma visão ampla do setor. Assim, há necessidade de pesquisas focando nos operadores e, sobretudo, com maior controle dos elementos para ampliar sua validade, e voltadas para tópicos específicos.

A tese procura preencher algumas das lacunas apontadas, estudando como operadores logísticos que atuam no mercado brasileiro vêm utilizando as tecnologias da informação. No caso particular da TI, existem poucos trabalhos acadêmicos abordando este tópico. Diante da grande quantidade de aplicações existentes e da velocidade no desenvolvimento de novas aplicações são importantes estudos que identifiquem as ferramentas de TI disponíveis no mercado e analisem como vem sendo utilizadas.

Os resultados da pesquisa devem indicar:

- A utilização ou não de aplicativos customizados para o atendimento das particularidades dos operadores investigados,

- As relações existentes entre TI e as características do setor, e entre TI e as políticas de produção dos clientes e, finalmente,

- O papel da TI para o estabelecimento das redes de valor.

A tese será dividida em duas partes.

A primeira parte é um referencial teórico que pretende fornecer os elementos que fundamentarão a pesquisa (BONOMA, 1985). Assim, constitui um estudo exploratório com o 
objetivo de identificar as questões relevantes que deverão ser contempladas na pesquisa empírica.

O capítulo 1 aborda os conceitos de estratégia, cadeia de valor, redes e rede de valor. O capítulo 2 apresenta os conceitos de cadeia de suprimentos e de SCM. O capítulo 3 apresenta definição, objetivos, atividades da logística e o conceito de logística integrada. O capítulo 4 conceitua os operadores logísticos e descreve suas atividades. Finalmente, o capítulo 5, identifica e analisa as tecnologias de informação disponíveis e que podem ser utilizadas nas atividades logísticas.

A segunda parte do estudo refere-se à pesquisa empírica propriamente dita.

O capítulo 6 tem o objetivo de apresentar a metodologia que será utilizada na pesquisa: o estudo de casos. Coloca as questões de pesquisa, apresenta as proposições que darão subsídio aos estudos de caso e o protocolo de pesquisa onde estão definidas as regras para a pesquisa de campo.

O capítulo 7 faz uma breve análise da indústria logística e, em seguida, apresenta o estudo dos casos realizados. Os casos foram analisados de acordo com as questões e proposições da pesquisa e, ao final, comparados entre si. Finalmente, na conclusão, foi proposta uma caracterização dos níveis de integração externa entre os operadores logísticos estudados e os demais agentes da rede. 


\section{CAPÍtULO 1 \\ ESTRATÉGIA, REDES DE EMPRESA E REDES DE VALOR}

\subsection{Estratégia}

Porter (1996) define estratégia como um conjunto de atividades que proporciona um composto de valor único no mercado. Seu objetivo é estabelecer uma posição lucrativa e sustentável contra as forças que determinam a concorrência na indústria. Para Mintzberg, Ahlstrande e Lampel (2000) é planejar e executar, de forma consistente, um plano de ação que permita que a empresa atinja e mantenha, ao longo do tempo, um desempenho superior aos concorrentes.

O desempenho da empresa depende de dois fatores: lucratividade média da indústria e da posição relativa da empresa frente aos concorrentes. A lucratividade média é dada pela estrutura e desempenho da indústria, e a posição relativa pelas eventuais vantagens competitivas da empresa. Portanto, para definir a estratégia é preciso analisar estes dois referenciais: estrutura da indústria e vantagens competitivas.

\subsubsection{Análise estrutural da indústria}

Para Porter (2001), indústria é um grupo de empresas que fabricam produtos substitutos entre si. A estrutura da indústria é determinada pelas características técnicas e econômicas de seus produtos e processos e está relacionada às "cinco forças competitivas: poder dos compradores, poder dos fornecedores, ameaça de novos entrantes, ameaça de produtos substitutos e a rivalidade entre os atuais concorrentes" (PORTER, 2001, p. 94).

O embate entre essas forças é que determina como o valor econômico, criado por qualquer produto ou serviço, é dividido entre, de um lado, empresas de uma indústria e, de outro, compradores, fornecedores, distribuidores, concorrentes e novos entrantes.

A empresa decide quais serão suas ações estratégicas (ofensivas ou defensivas) para enfrentar com sucesso as forças competitivas e ampliar seus lucros. Para isto é preciso analisar cada uma delas separadamente e traçar ações que alterem o equilíbrio de poder a seu favor. A análise das forças permite identificar pontos fortes e fracos da empresa, oportunidades e ameaças e orientar o posicionamento estratégico. 
Por meio da análise estrutural, a empresa pode compreender o ambiente onde está operando e estabelecer uma estratégia que garanta desempenho superior.

\subsubsection{Vantagens competitivas}

Para Porter e Millar (1985), a empresa terá vantagens competitivas, que acarretam rentabilidade superior à média da indústria, quando for capaz de produzir com custos menores ou vender com preço superior aos concorrentes.

Porter e Millar (1985) classificam as vantagens competitivas em:

- Liderança em custo: produzir produto ou serviço semelhante aos da concorrência, mas com custo inferior - podendo, então, obter um lucro maior.

- Diferenciação: proporcionar um valor maior ao cliente podendo, neste caso, vender seu produto ou serviço a um preço superior ao do concorrente.

Custo e diferenciação são as unidades básicas da vantagem competitiva e refletem a forma como são desempenhadas todas as atividades que a empresa realiza para criar, produzir, vender e entregar produtos ou serviços.

As duas unidades básicas de vantagem competitiva devem ser associadas ao escopo, ou seja, a amplitude das atividades. O escopo competitivo pode assumir quatro dimensões:

- Escopo do segmento: variedade dos produtos produzidos e clientes atendidos;

- Escopo geográfico: localidades de atuação;

- Escopo setorial: variedade de indústria onde atua;

- Escopo vertical: definição das atividades realizadas internamente e por parceiros.

A adoção de um escopo amplo permite que a empresa explore as relações existentes entre os diferentes segmentos, áreas geográficas ou setores afins. Porter (1985) cita o caso de unidades de negócio que podem compartilhar vendedores, coordenar compras de componentes comuns ou explorar os benefícios decorrentes da execução de mais atividades próprias, prescindindo de fornecedores.

Um escopo estreito, por sua vez, permite atender segmentos específicos, áreas geográficas ou uma indústria em particular, oferecendo custos mais baixos ou diferenciação. A empresa é capaz de atender particularidades dos compradores ou mercados que seus concorrentes com escopo amplo não conseguem.

As vantagens competitivas decorrem da forma como as atividades são executadas e combinadas (MARKIDES, 1999). Vantagens de custo resultam da execução das atividades de 
forma mais eficaz que os concorrentes. Diferenciação, do posicionamento estratégico, ou seja, da escolha das atividades e da sua forma de execução.

\subsubsection{Eficácia operacional}

Eficácia operacional é a capacidade de executar as atividades melhor que os concorrentes. Inclui o conceito de eficiência, mas é mais abrangente. Refere-se a qualquer prática que permita à empresa utilizar melhor os insumos, tais como: eliminação de desperdícios, adoção de tecnologia mais avançada, funcionários mais motivados, melhor gerenciamento de determinadas atividades ou do conjunto delas.

Todas as empresas devem buscar a eficácia operacional. As diferenças na eficácia é que geram diferentes rentabilidades entre as empresas, permitindo custos menores e maior qualidade. Mas, eficácia, por si só, não garante a manutenção das vantagens competitivas ao longo do tempo: qualquer melhoria operacional tende a ser rapidamente identificada e copiada pelos concorrentes. Assim, além da eficácia, a empresa deve buscar um posicionamento estratégico que garanta uma proposição de valor único.

\subsubsection{Posicionamento estratégico}

Posicionamento estratégico é determinado pelas escolhas da empresa quanto a quais clientes focar e quais produtos oferecer. A partir do posicionamento estratégico a empresa estabelece as atividades que serão realizadas e a forma de execução.

Porter (1999) identifica três tipos de posicionamento, não excludentes e geralmente entremeados:

- Posicionamento baseado na variedade: define um subconjunto de produtos ou serviços de um setor para produzir. É adequado quando a empresa é capaz de realizar as atividades de forma diferenciada.

- Posicionamento baseado nas necessidades: atende à maioria das necessidades de um determinado grupo de compradores. É adequado quando existe um grupo de clientes com necessidades diferenciadas e que necessitam de atividades executadas sob medida.

- Posicionamento baseado no acesso: atende compradores com necessidades semelhantes, mas que exigem diferentes formas de acesso. As atividades necessárias para atender compradores rurais e urbanos, por exemplo. 
O posicionamento estratégico resulta em vantagens competitivas quando as atividades são executadas e combinadas para obter um produto ou serviço diferenciado. Diferenciação exige que a empresa execute novas atividades não realizadas pelos concorrentes, ou as mesmas atividades, porém de novas formas.

Para estabelecer e manter um posicionamento estratégico único, a empresa precisa seguir seis princípios fundamentais (MARKIDES, 1999):

- Ter como meta de longo prazo obter retorno superior do investimento. A estratégia deve estar fundamentada na sustentação da lucratividade, gerando valor econômico real.

- Ter como objetivo proporcionar valor ou conjunto de benefícios diferente dos concorrentes. Portanto, não é a universalização das melhores práticas e nem um esforço para oferecer tudo para todos. Deve definir uma forma de competir que gere valor único para um conjunto específico de clientes.

- Realizar de forma diferente suas atividades ou realizar atividades diferentes das realizadas pelos concorrentes. As atividades devem estar adequadas à sua proposição única de valor.

- Abandonar algumas características dos produtos, serviço ou atividades para ser única em outras. Estratégia envolve escolhas.

- Definir como irão operar todos os elementos de uma empresa. Estratégia envolve escolhas que são interdependentes e, portanto, todas as atividades devem ser reforçadas mutuamente.

- Definir uma proposição de valor único para seguir, mesmo que implique na perda de oportunidades.

Assim, para que as vantagens competitivas mantenham-se ao longo do tempo, as atividades devem ser compatíveis entre si e com o posicionamento estratégico da empresa (Porter, 1996). "Se não houver compatibilidade entre as atividades, não existirá estratégia diferenciada e a sustentabilidade será mínima" (PORTER, 1996, p. 73).

\section{$\mathbf{X}-\mathbf{X}-\mathbf{X}$}

Como visto, o desenvolvimento da estratégia em uma empresa requer a análise de dois referenciais: estrutura da indústria e vantagens competitivas. A estrutura da indústria fornece os elementos para a compreensão do ambiente onde a empresa está operando; e a vantagem competitiva indica a posição da empresa frente aos concorrentes.

Mas a vantagem competitiva não pode ser compreendida analisando-se a empresa como um todo. Ela decorre da forma como são executadas e de como estão relacionadas cada 
uma das atividades distintas que a empresa realiza para o desenvolvimento de seus produtos ou serviços. Assim, para a análise das vantagens competitivas, Porter e Millar (1985) desenvolveram o conceito de cadeia de valor.

"A cadeia de valor desagrega uma empresa em suas atividades de relevância estratégica para que se possa compreender o comportamento dos custos e as fontes de vantagens existentes e potenciais de diferenciação" (PORTER; MILLAR, 1985, p. 31).

\subsubsection{Cadeia e Sistema de Valor}

Cadeia de valor é uma estrutura composta pelas várias atividades - e suas interações necessárias para a elaboração e oferta de produtos ou serviços para o cliente final. Identifica as "várias atividades diferenciadas, do ponto de vista tecnológico e econômico, que a empresa desempenha para executar seu negócio” (PORTER; MILLAR, 1985, p. 35).

A figura abaixo representa uma cadeia de valor genérica.

Figura 1 - Cadeia de Valor Genérica

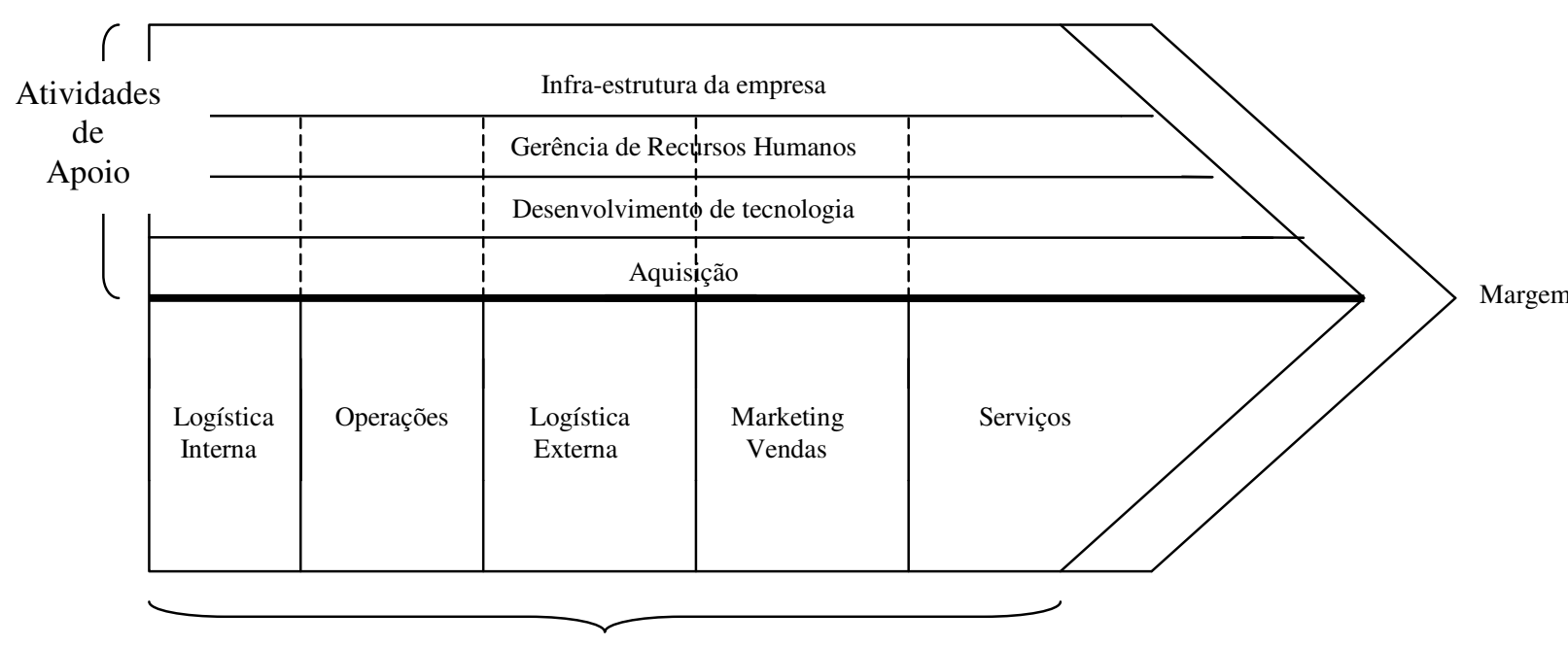

Atividades Primárias

Fonte: Porter e Millar (1985, p. 35).

Porter e Millar (1985) decompõem a cadeia em nove atividades de valor e a margem. As atividades de valor são atividades física e tecnologicamente distintas que permitem à empresa criar valor para seus compradores. Cada atividade utiliza insumos, recursos humanos e tecnologia e gera e utiliza informação. 
A configuração da cadeia de valor, sua forma, é dada pela definição do escopo competitivo, pelas características da estrutura industrial (determina as negociações com compradores e fornecedores, refletindo na configuração da cadeia) e pela estrutura organizacional (forma como são agrupadas as atividades). Assim, empresas concorrentes de uma mesma indústria podem ter cadeias de valor diferentes. Ou ainda, uma empresa pode operar com diversas cadeias para produzir diferentes produtos, ou atender diferentes compradores, áreas geográficas ou canais de distribuição.

O fluxo de bens de valor agregado tem início no suprimento de produtos e materiais. As empresas vão adicionando valor aos materiais e produtos recebidos de seus fornecedores a cada etapa do processo produtivo. O valor é efetivamente realizado no momento da transferência para o comprador final (RUTNER; LANGLEY, 2000).

O valor gerado é dado pela receita total. Receita total é o preço que os compradores estão dispostos a pagar pelo produto ou serviço, multiplicado pelo número de unidades vendidas. Margem é a diferença entre o valor total e o custo de execução de todas as atividades necessárias para a produção do produto ou serviço.

As diversas atividades de valor da empresa estão ligadas entre si. Os elos surgem quando a forma de execução de uma atividade afeta o custo ou o desempenho das demais. Além das ligações internas, a empresa também está conectada às cadeias de valor de seus fornecedores, distribuidores e compradores. Porter e Millar (1985) chamaram as ligações verificadas entre as atividades internas de elos horizontais e, de verticais as ocorridas entre a empresa e seus parceiros externos.

Para Porter (1979), as maiores oportunidades de criação de valor estão localizadas nos elos, tanto horizontais como verticais. Uma boa gestão dos elos pode se constituir numa poderosa fonte de vantagem competitiva por duas razões: não é facilmente notada pelos concorrentes e ressalta incompatibilidades existentes entre as atividades.

Por exemplo:

- Nos elos horizontais: o processo de aquisição de insumos por uma empresa afeta a qualidade destes e, conseqüentemente, os custos de produção e as características dos seus produtos finais.

- Nos elos verticais: características dos produtos de um fornecedor ou uma logística mais eficiente podem afetar o custo ou diferenciar a empresa de seus concorrentes.

Porter e Millar (1985) denominaram as diversas cadeias de valor, ligadas por meio de elos verticais, de sistema de valor. A figura abaixo representa um sistema de valor genérico. 
Figura 2 - Sistema de Valor

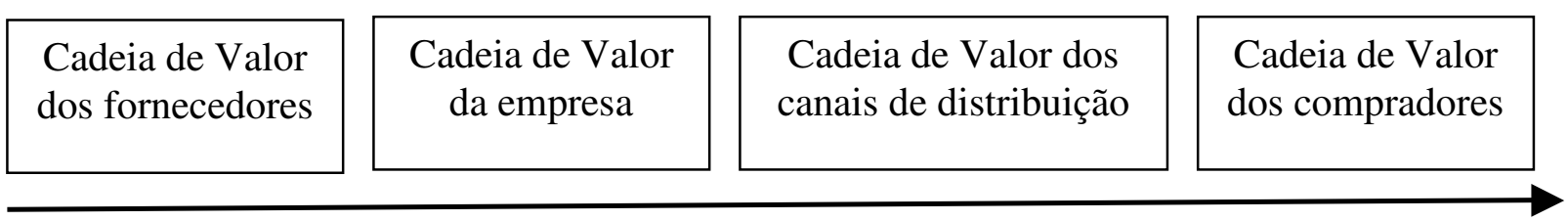

Fonte: Porter e Millar (1985, p. 86).

Sistema de valor engloba, portanto, as cadeias dos fornecedores, da empresa produtora, dos distribuidores e dos compradores. O produto resultante pode, novamente, ser utilizado como insumo na cadeia do comprador, e assim por diante. Por meio do conceito é possível identificar e analisar os elos verticais.

Diversas tendências observadas nas principais economias capitalistas vêm afetando as cadeias e sistemas de valor. Britto (2002) aponta algumas destas tendências:

- Incorporação de novos princípios gerenciais que priorizam a cooperação interindustrial;

- Estruturação de sistemas produtivos que incorporam o conceito de especialização flexível enquanto princípio organizador das atividades;

- Acirramento da concorrência e da globalização dos mercados que estimulam a consolidação de alianças estratégicas;

- Aglutinação de diferentes competências e do estabelecimento de projetos colaborativos para realização de novas atividades.

Estas tendências vêm levando as empresas à terceirização da produção e ao estabelecimento de parcerias em diferentes regiões do planeta. O resultado são sistemas de valor cada vez mais complexos e que se assemelham à redes de empresas (REYES; RAISINGHANI; SINGH, 2002; DRUCKER, 2001).

\subsection{Redes de empresas}

Antes, as organizações eram estruturadas verticalmente. Os executivos procuravam controlar as operações vitais para o funcionamento de suas empresas comprando outras empresas de seu canal de distribuição (BOWERSOX; COOPER, 1992). 
O objetivo central era obter vantagens de custo, gerenciando as fontes externas. Acreditavam que controlando todos os estágios do processo de produção poderiam se tornar mais eficientes. Assim, mantinham internamente as funções necessárias para a execução de suas atividades, utilizando fontes externas somente para atividades de apoio.

A execução destas funções não exigia o estabelecimento de alianças ou parcerias de longo prazo. Compradores e vendedores mantinham relacionamentos face a face, de curto prazo e com sua independência preservada. Assim, não eram relações cooperativas, com os participantes, muitas vezes, competindo pelos recursos.

Progressivamente, para diminuir custos e ganhar competitividade, muitas empresas passaram a integrar suas unidades e parceiros. A relação com fornecedores passou a se basear na confiança, o ambiente passou de competitivo para colaborativo e os relacionamentos antes de curto prazo e voltados para a redução dos custos - passaram a ser estratégicos visando, agora, adicionar valor.

Redes de empresa são constituídas por meio de arranjos - geralmente de caráter cooperativo - entre empresas independentes e que resultam em uma forma particular de coordenação das atividades econômicas (BRITTO, 2002).

Para Britto (2002), as principais características destas estruturas são:

- Elevado grau de compatibilidade e complementaridade técnica entre os agentes e atividades.

- Elevado grau de integração das atividades produtivas devido às:

- Interdependências técnicas: mudanças nas características das funções de produção;

- Interdependências pecuniárias: mudanças nos preços relativos dos fatores e nas estruturas de custo das empresas;

- Interdependência de demanda: mudanças na demanda de uma unidade em decorrência de modificações na demanda de outras.

- Mudanças no ritmo de adoção e difusão das inovações e outros ganhos decorrentes do progresso técnico devido à complementaridade entre as competências.

- Consolidação de infra-estrutura de apoio, que impõe certa irreversibilidade quanto aos investimentos realizados.

O sucesso da rede depende não só do desempenho individual de cada empresa, mas, sobretudo, da gestão dos seus relacionamentos e processos externos (BOWERSOX; CLOSS; STANK, 1999). A competitividade decorre da partilha de recursos, da racionalização das 
tarefas e da sincronização das atividades, permitindo estoques menores e um melhor desempenho financeiro (GRAHAM; HARDAKER, 2000).

Segundo Britto (2002), o estabelecimento das redes pode contribuir para a competitividade de três maneiras:

- Aumento da eficiência operacional decorrente da exploração de economias técnicas e a redução de custos de produção e transação;

- Melhor enfrentamento da concorrência decorrente da coordenação das decisões produtivas e tecnológicas dos agentes;

- Reforço da capacitação tecnológica e do potencial inovativo dos agentes decorrente da criação, circulação e difusão de informações e de um maior aprendizado.

O estabelecimento das redes de empresas muda a forma de entender competição (LAMBERT; COOPER; PAGH, 1998). Enquanto para as empresas individualmente é difícil obter, simultaneamente, vantagens competitivas decorrentes de diferenciação e da liderança em custos (PORTER; MILLAR, 1985), nas redes a realidade é outra. Operando em rede, as empresas podem oferecer produtos e serviços personalizados e com qualidade elevada mantendo-se competitivas em preço (VENKATRAMAN, 1994; NARASIMHAN; KIM, 2001; LAMBERT; COOPER; PAGH; 1998).

As vantagens competitivas das redes decorrem da administração do sistema como um todo (LEWIS; TALALAYEVSKY, 2000). Há consenso entre os autores (BOWERSOX; CLOSS, 2001; LAMBERT; COOPER; PAGH, 1998) que para que o conjunto de empresas possa operar como uma única organização deve ser capaz de integrar e coordenar suas atividades.

\subsubsection{Integração e coordenação}

Graham e Hardaker (2000) definem integração como a ligação - estratégica e operacional - dos processos de negócios entre os agentes. Coordenação, por sua vez, é a sincronização dos fluxos de material, informação e recursos entre os diferentes parceiros, garantindo que ocorram no momento e quantidade adequados, sem interrupções ou falhas (TURBAN; RAINER; POTTER, 2003).

Por meio da integração, as informações podem ser compartilhadas entre os fornecedores, fabricantes e compradores. A coordenação, por sua vez, garante o controle, por uma ou mais empresas, das atividades economicamente dispersas e a execução conjunta dos processos empresariais. 
A troca de informação, freqüentemente, precede o movimento físico de materiais e produtos (PORTER, 2001). Assim, disponibilidade e acesso a informações precisas e atualizadas são fundamentais para que as atividades e agentes da cadeia possam operar de forma sincronizada, como uma única organização (BOWERSOX; CLOSS, 2001; ASSUMPÇÃO, 2003; TURBAN; RAINER; POTTER, 2003).

A ausência de integração e coordenação efetivas pode acarretar diferentes problemas. Entre eles: atraso nos pedidos, menor qualidade, estoques elevados, maiores custos, lentidão no atendimento ao comprador e obsolescência do produto devido aos longos ciclos dos pedidos (COHEN; MALLIK, 1997).

Mas integrar e coordenar diferentes empresas não é uma tarefa simples. A coordenação implica o estabelecimento de parâmetros e regulamentações: uma ou mais empresas estabelecem diretrizes que serão seguidas pelos demais participantes. E a integração, sobretudo em seus estágios mais avançados, supõe forte relação de confiança, metas comuns e compatibilidade técnica entre os parceiros. A integração e coordenação dos processos pressupõem, portanto, o estabelecimento de parcerias (CHOPRA; MEINDL, 2001).

As parcerias garantem um desempenho superior ao que seria obtido pelas empresas individualmente, trazendo ganhos para todos. Lambert, Emmelhainz e Gardner (1996) reforçam este argumento, defendendo que o estabelecimento de parcerias com fornecedoreschave, compradores e terceirizados contribuem para a manutenção de uma posição de liderança e crescimento.

\subsubsection{Alianças ou parcerias}

Parceria, ou aliança, é o estabelecimento de relacionamento próximo entre duas ou mais empresas. Baseia-se no intercâmbio de informações, aglutinação de competências e exploração de oportunidades tecnológicas e de mercado promissoras. O relacionamento deve estar baseado na confiança mútua, direta, com partilha dos riscos e ganhos.

Britto (2002) identifica três diferentes motivações para o estabelecimento de parcerias:

- Integração conjunta das atividades visando atingir estágio mais avançado na cadeia de produção e comercialização de bens;

- Configuração aditiva que articula duas ou mais empresas de determinada indústria visando aumento da escala, ampliação do mercado interno e enfraquecimento da concorrência;

- Configuração complementar que integra duas ou mais empresas visando ampliar competências complementares e, portanto, melhorar competitividade. 
Os relacionamentos podem ser com ou sem dominância. A dominância é dada pela capacidade da empresa em impor sua forma de operar, suas estratégias e as tecnologias que serão utilizadas.

Pesquisa desenvolvida por Lambert, Emmelhainz e Gardner (1996) indicou a existência de três tipos de parcerias. São elas:

- As organizações reconhecem-se como parceiras e coordenam planejamento e as atividades de forma limitada. A parceria tem foco no curto prazo e envolve somente uma área funcional das empresas.

- As empresas vão além da coordenação para a integração das atividades. O horizonte é de longo prazo e envolve diversas áreas e funções.

- As empresas partilham um nível significativo de integração operacional. Cada parte vê o outro como uma extensão de si próprio. As parcerias são duradouras e estão restritas aos fornecedores e compradores mais importantes.

Os autores concluem que não existe um modelo ideal de parceria. Cada uma tem seus próprios motivadores, um ambiente único de operação, duração, profundidade, proximidade, etc.; que variam caso a caso e ao longo do tempo.

\subsubsection{Redes de valor}

Bovet e Martha (2001) definem rede de valor como uma rede dinâmica de parcerias entre compradores e fornecedores e o fluxo de informação. Estas redes são capazes de atender à demanda do comprador de forma rápida e confiável. A rede de valor tem esta denominação porque cria valor para todos os participantes - empresa, fornecedores e compradores. Os agentes operam de forma colaborativa e estão interligados digitalmente.

Estudo realizado pela Mercer Management Consulting com 30 empresas em todo o mundo aponta cinco características básicas das redes de valor (BOVET; MARTHA, 2001):

- Alinhamento com o cliente: capaz de atender de forma personalizada os compradores. As atividades da empresa e de sua rede de fornecedores são definidas a partir das necessidades dos clientes.

- Cooperação e sistematização: fornecedores e clientes estão engajados nas redes de valor. Cada atividade é executada pelo parceiro mais capacitado.

- Agilidade e flexibilidade: assegurada por meio da produção e distribuição flexíveis, e pelo fluxo de informação. A rede é capaz de responder a alterações na demanda, adequando-se rapidamente às necessidades dos parceiros e mercados. 
- Rapidez no fluxo de produtos e serviços: diminui o tempo de atendimento dos pedidos e necessidade de estoques. Bens acabados são remetidos rapidamente.

- Digital: sistemas de informação formam o backbone neural da rede, conectando clientes e fornecedores por meio de atividades de valor adicionado.

Todas estas características apontadas pelos autores indicam que, para que uma rede possa constituir uma rede de valor, os fluxos e estoques de matérias, serviços e informação devem ser administrados como um processo contínuo entre as empresas. Assim, a gestão integrada da função logística entre os diversos agentes constitui a base para o estabelecimento de uma rede de valor.

Britto (2002) afirma que o conceito de rede torna possível a caracterização e o estudo de estruturas complexas e dinâmicas, suas formas de operação e relações que conectam os diferentes agentes. Assim, permite investigar temas como alianças estratégicas entre empresas, outras formas de cooperação produtivas e tecnológicas e processos de subcontratação e terceirização.

É possível compreender um pouco melhor o fenômeno das redes a partir da observação das cadeias de suprimentos. Embora o conceito de rede seja mais amplo, a cadeia de suprimentos oferece uma estrutura básica para o seu entendimento. A cadeia indica as atividades e as ligações lógicas dos elementos envolvidos no processo produtivo (VANHARANTA; BREITE, 2004). O próximo capítulo apresenta os conceitos de cadeia de suprimentos e de gestão da cadeia de suprimentos. 


\section{CAPÍTULO 2}

\section{CADEIA DE SUPRIMENTOS E SUPPLY CHAIN MANAGEMENT}

\subsection{Cadeia de suprimentos}

O Global Supply Chain Forum define a cadeia de suprimentos como o conjunto das organizações, recursos e atividades conectadas e comprometidas com a criação, distribuição e venda de produtos acabados e serviços para o consumidor final. Envolve fornecedores de matéria-prima, plantas produtivas, centros de distribuição, varejistas, estoque em trânsito e produtos acabados (LAMBERT; COOPER; PAGH, 1998).

Outras definições semelhantes podem ser encontradas na literatura. Para Porter e Millar (1985), é um conjunto de empresas independentes operando juntas para obter vantagens frente às oportunidades existentes no mercado. Para Swaminathan, Smith e Sadeh (1998) cadeia de suprimentos é uma rede de entidades de negócios - autônomas e semiautônomas - responsáveis pelas atividades de aquisição, manufatura e distribuição de um ou mais produtos. Para Mentzer et al. (2001), é o conjunto de entidades (organizações ou indivíduos) envolvidas diretamente nos fluxos de produtos, serviços, finanças e informações, desde o primeiro fornecedor até o cliente final.

As cadeias de suprimentos podem assumir diferentes formas, tamanhos e graus de complexidade de acordo com os produtos, processos de produção e posicionamento estratégico das empresas (LAUDON; LAUDON, 2004). A figura abaixo representa uma cadeia de suprimentos genérica, com a empresa conectada a seus fornecedores (à esquerda) e aos seus distribuidores e clientes (à direita). Os fornecedores, por sua vez, estão ligados a outros fornecedores (de segundo nível). Além do fluxo de materiais e produtos, ocorre também o fluxo de informação e de capital. 
Figura 3 - Cadeia de Suprimentos

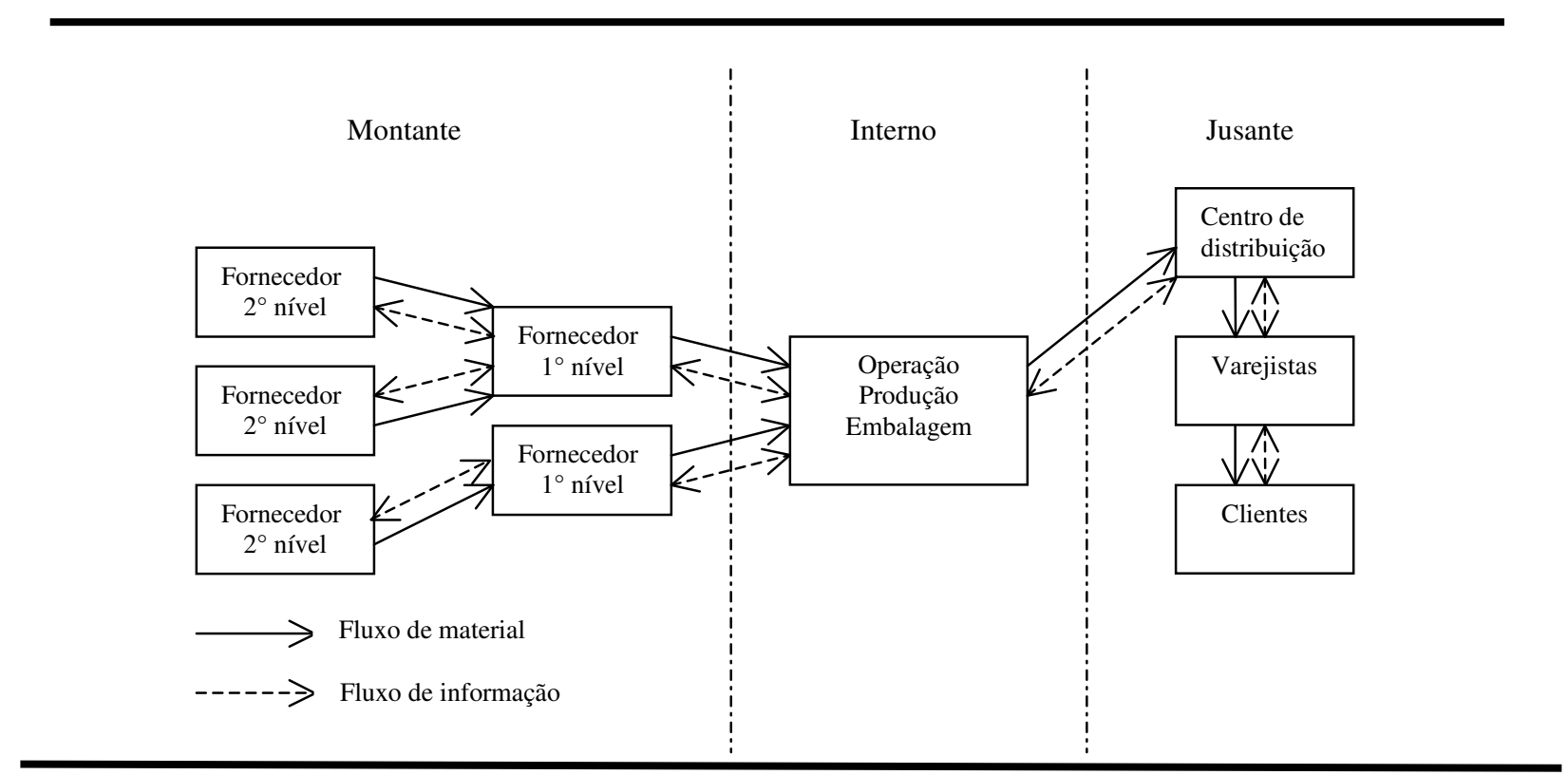

Fonte: adaptado de Laudon e Laudon (2004).

A cadeia de suprimentos é composta dos três segmentos (LAUDON; LAUDON, 2004):

- Segmento a montante (upstream): inclui os fornecedores da empresa (primeiro nível) e os fornecedores de seus fornecedores (segundo nível). Pode, ainda, ser ampliado até o fornecedor das matérias primas básicas. As principais atividades neste segmento são compras e entregas.

- Segmento interno: inclui todos os processos que a empresa realiza para transformar os materiais recebidos em produtos, desde o ingresso na organização até a remessa do produto para distribuição. As principais atividades deste segmento são movimentação de materiais, gerenciamento dos estoques, fabricação e controle de qualidade.

- Segmento a jusante (downstream): inclui a distribuição e entrega dos produtos para os clientes finais. As atividades deste segmento incluem embalagem, estoque e entregas; e podem ser executadas por distribuidores atacadistas e varejistas.

A partir do conceito de cadeia de suprimentos, Mentzer et al. (2001) extraem algumas evidências importantes:

- É um fenômeno inerente aos negócios.

- Abrange todo o ciclo de vida dos produtos.

- O comprador é um membro. 
- A empresa, geralmente, participa de diversas cadeias, podendo ocupar papéis e operar de diferentes formas em cada uma delas.

\subsubsection{Dinâmica de operação da cadeia de suprimentos}

A dinâmica de operação das cadeias de suprimentos é dada pelos fluxos de materiais, serviços e informação estabelecidos pela logística. Os fluxos têm início a partir da decisão de produzir tomada pelas empresas.

As empresas decidem produzir a partir das expectativas de vendas ou dos pedidos efetivamente realizados. Adquirem os materiais e componentes de seus fornecedores e efetuam o processamento, agregando valor (CHANDRASHECAR; SCHARY, 1999).

- Se a produção está baseada na previsão de vendas - produção para estoque - as empresas compram e transformam insumos em produtos acabados antes que o pedido seja efetuado, a partir de suas expectativas de venda. Este modelo de produção é chamado push porque "empurra" os estoques nos canais de distribuição. Pode levar à produção, distribuição, armazenagem e transporte de quantidades superiores à demanda real.

- Se a produção está apoiada nos pedidos dos clientes - produção contra pedido - o processo produtivo tem inicio a partir das vendas já realizadas. Este modelo de produção é chamado pull porque "puxa" os estoques nos canais de distribuição. As empresas compram e transformam insumos em produtos acabados para atender pedidos já efetuados. Como atende a demanda real, opera com níveis mais baixos de estoques e exige acesso às informações de venda em tempo real.

O modelo de produção push opera, de forma geral, com estoques descentralizados em diversas instalações e consolidação do transporte para utilização de modais mais baratos e lentos. Descentralizar os estoques significa antecipar transporte e movimentação para instalações intermediárias baseando-se na previsão de vendas futuras.

A execução destas funções não exige o estabelecimento de alianças ou parcerias de longo prazo. Compradores e vendedores mantêm relacionamentos face a face, de curto prazo e com sua independência preservada. Assim, não são relações cooperativas, com os participantes, muitas vezes, competindo por recursos.

O modelo de produção pull opera, de forma geral, com estoques centralizados e utilização de modais de transporte mais caros. Centralização de estoques significa postergar ao máximo o transporte de produtos, movimentando-os somente no momento em que o cliente final efetuar o pedido. 
Estes sistemas exigem monitoramento em tempo real, sendo que as informações devem ser partilhadas por todos os participantes. Assim, as relações devem ser colaborativas e o papel das alianças e parcerias é central. Os relacionamentos estabelecidos são de longo prazo e visam, sobretudo, adicionar valor.

Turban, Rainer e Potter (2003) classificaram as cadeias de acordo com sua dinâmica.

- Produção integrada ao estoque: acompanha a demanda dos clientes em tempo real para produzir e repor os estoques de forma eficiente. A empresa modifica programações e planos de produção, assim como a entrada de materiais, de acordo com as variações observadas na demanda. Utiliza, de forma geral, sistemas de informação plenamente integrados, como os sistemas empresariais.

- Reabastecimento contínuo (continuous replenishment): repõe continuamente o estoque operando em conjunto com fornecedores ou intermediários. Sistemas integrados, com informações sobre a demanda em tempo real, permitem a manutenção dos níveis desejados de reposição. Este modelo se aplica melhor em indústrias que mantêm um padrão de demanda relativamente estável, como é o caso de medicamentos receitados.

- Fabricação por pedido (build-to-order): o produto é elaborado após a realização do pedido. Exige administração cuidadosa dos estoques de componentes e do abastecimento ao longo da cadeia para permitir o atendimento rápido e eficiente. Este modelo se aplica melhor quando diferentes produtos são elaborados utilizando componentes comuns. A fabricação de produtos utilizando este modelo de cadeia de suprimentos permite a customização em massa.

- Montagem no canal: o produto é elaborado à medida que se desloca no canal de distribuição. Envolve, necessariamente, alianças estratégicas com empresas de logística terceirizadas que reúnem os componentes dos produtos para entrega ao consumidor. Este modelo não exige a manutenção de estoques.

\subsubsection{Problemas na cadeia de suprimentos}

Para enfrentar a competição crescente, as empresas vêm terceirizando sua produção e estabelecendo parcerias em diferentes regiões do planeta. Várias razões levam as empresas a se tornarem globais: buscar preços inferiores ou qualidade superior do material, produtos e trabalho; estar mais próxima de seus fornecedores ou clientes; ter acesso a tecnologias mais desenvolvidas, etc. 
O resultado são cadeias de suprimentos cada vez mais complexas podendo, inclusive, estar sujeitas a diferentes regulamentações, culturas, políticas cambiais, etc. (REYES; RAISINGHANI; SINGH, 2002). Quanto mais complexa, maior a probabilidade da ocorrência de problemas, já que é mais difícil coordenar inúmeras atividades, unidades e parceiros (TURBAN; LEE; KING; CHUNG, 2002).

Os problemas identificados com maior freqüência são: empresas incapazes de atender a demanda de alguns produtos enquanto mantêm grandes estoques de outros, produtos com qualidade insatisfatória, custos elevados de operação e remessa, falhas nas trocas de informação, erros de previsão, etc. (TURBAN; LEE; KING; CHUNG, 2002).

O efeito chicote, por exemplo, é um dos problemas mais discutidos na literatura e foi identificado pela primeira vez pela Procter \& Gamble $(P \& G)$. A empresa observou que, embora a demanda por fraldas fosse estável e previsível, ocorriam mudanças repentinas nos pedidos dos atacadistas e distribuidores. Estas alterações bruscas criavam problemas de produção e estoques.

Investigando as causas, constatou-se que as flutuações resultavam de erros nas previsões, ausência de coordenação e desconfiança entre os parceiros da cadeia. Como cada parceiro decidia isoladamente seus estoques, observando exclusivamente seus interesses, os erros propagavam-se pela cadeia atingindo diversas unidades.

Estoques baixos não permitem atender rapidamente a um aumento na demanda ou evitar atrasos na entrega. Mas, por outro lado, estoques em excesso elevam o custo de operação. A questão é determinar o nível adequado de estoque de cada peça e produto para que não ocorram interrupções ou falhas nos processos.

A gestão integrada tem sido vista como a principal forma para enfrentar os inúmeros problemas que afetam a cadeia de suprimentos. O sucesso depende da capacidade para integrar e coordenar as diversas atividades e processos que a compõem. Por meio da gestão integrada, as diversas empresas da cadeia são capazes de operar como uma única organização (BOWERSOX; CLOSS, 2001; CHEN, YANG, CHIA; 2007).

\subsection{Supply Chain Management}

O termo Supply Chain Management (SCM) ou Gestão da Cadeia de Suprimentos foi criado por consultores e apareceu pela primeira vez no início dos anos 80. Desde então, vários autores buscaram uma definição para SCM. 
Mentzer et al. (2001) definem SCM como a coordenação - estratégica e sistêmica - das funções tradicionais do negócio nas empresas. Para Lambert, Cooper e Pagh (1998), é a administração integrada dos vários relacionamentos na cadeia de suprimentos.

A definição adotada pelo Global Supply Chain Forum é a mais ampla. Define SCM como a integração e gestão de todos os processos-chave dos negócios, desde os fornecedores até os compradores finais. Processos-chave são aqueles capazes de agregar valor aos produtos, serviços e informação (LAMBERT; COOPER; PAGH, 1998).

Cooper, Lambert e Pagh (1997) observam que:

- no conceito estão incluídos os fluxos bidirecionais de produtos (material e serviços) e informação associados às atividades operacionais e de gestão;

- pode haver diferentes níveis de integração na cadeia, sendo que no mais elevado estariam envolvidos todos os participantes, do primeiro fornecedor até o cliente final;

- a coordenação tem um papel central, já que estão envolvidas inúmeras organizações independentes;

- tem como objetivo ampliar o valor oferecido aos clientes utilizando adequadamente os recursos e construindo uma cadeia de vantagens competitivas.

SCM envolve, portanto, planejamento, organização, coordenação e controle de diferentes unidades, parceiros e atividades, combinação de várias técnicas, além do uso intensivo da tecnologia da informação (TURBAN; LEE; KING; CHUNG, 2002). Informação e, mais importante, sistemas de informações ágeis são amplamente reconhecidos como fatores críticos para atingir um bom desempenho na cadeia de suprimentos (WHITEA; DANIELB; MOHDZAINC; 2005).

\subsubsection{Objetivos da SCM}

O objetivo da SCM é buscar a excelência dos processos como um todo e representa uma nova maneira de administrar os negócios. Turban, Lee, King e Chung (2002) apontam metas que podem contribuir para o desempenho global da cadeia e que, portanto, devem ser buscadas pelos gestores:

- desenhar uma cadeia de suprimentos mais eficiente;

- minimizar o custo operacional total;

- ampliar o conhecimento sobre os compradores;

- desenvolver produtos com maior qualidade; 
- oferecer maior satisfação ou valor aos compradores;

- responder mais rapidamente ao mercado, reduzindo o tempo de desenvolvimento e remessa de novos produtos;

- ampliar o controle dos estoques.

Reyes, Raisinghani e Singh (2002), baseados em estudos de caso, levantam mais alguns pontos:

- adoção de um modelo único de negócio;

- estabelecimento de metas;

- foco no negócio e nos processos;

- comprometimento das pessoas;

- tecnologias adotadas;

- remessa regular de valor;

- agilidade para se adaptar a novas situações (flexibilidade);

- liderança forte;

- distribuição adequada dos ganhos e benefícios entre os parceiros.

\subsubsection{Níveis de integração}

A integração é um processo complexo e que deve ser implantado de forma gradativa. Tem início dentro das organizações para, depois, se estender além dos limites da empresa, incorporando outras organizações Os níveis mais elevados de integração pressupõem a passagem pelos estágios inferiores (VENKATRAMAN, 1994).

Em seus estágios mais elevados, a integração exige o estabelecimento de padrões comuns entre as empresas. Devem estar padronizados as tecnologias de comunicação, os sistemas de codificação para materiais e produtos e as práticas de automação e gestão (CHANDRASHEKAR; SCHARY, 1999; GUNASEKARAN; NGAI, 2004).

Stevens (1989) identifica quatro estágios evolutivos - descritos no quadro 1 abaixo necessários para atingir a integração completa da cadeia. 


\section{Quadro 1}

Estágios de integração para gestão da cadeia de suprimentos

\begin{tabular}{|c|c|}
\hline Estágio & Definições \\
\hline $\begin{array}{l}1^{\circ} \text { Estágio } \\
\text { Operação independente das } \\
\text { funções }\end{array}$ & $\begin{array}{l}\text { Vendas, produção, planejamento, controle de material e compras são } \\
\text { operados individualmente. } \\
\text { Caracterizado pelos limites organizacionais: } \\
\text { - Função compras: controla o fluxo de matéria prima. } \\
\text { - Função manufatura e produção: controla a matéria prima ao longo do } \\
\text { processo de transformação em produto acabado e na cadeia. } \\
\text { - Função vendas e distribuição: controla a cadeia de suprimentos externa } \\
\text { e estoques. }\end{array}$ \\
\hline $\begin{array}{l}2^{\circ} \text { Estágio } \\
\text { Integração funcional }\end{array}$ & $\begin{array}{l}\text { Integração limitada entre algumas funções (por exemplo, remessa e estoque } \\
\text { ou compra e gestão de matéria prima) } \\
\text { Caracterizado pela ênfase na redução de custo e não na melhora no } \\
\text { desempenho: } \\
\text { Cada função do negócio é tratada de forma distinta, estando protegida por } \\
\text { estoques, trades-off internos, elevada utilização da planta, etc. }\end{array}$ \\
\hline $\begin{array}{c}3^{\circ} \text { Estágio } \\
\text { Integração interna }\end{array}$ & $\begin{array}{l}\text { Todas as funções internas - da gestão da matéria prima à produção, } \\
\text { transporte e vendas - estão integradas em tempo real. } \\
\text { Caracterizado pela visibilidade total dos sistemas: } \\
\text { - } \quad \text { Foco na tática ao invés de priorizar as questões estratégicas; } \\
\text { - } \quad \text { Ênfase na eficiência e não na eficácia; } \\
\text { - } \quad \text { Reage à demanda do cliente e não à gestão do cliente. }\end{array}$ \\
\hline $\begin{array}{c}4^{\circ} \text { Estágio } \\
\text { Integração externa }\end{array}$ & $\begin{array}{l}\text { Integração completa da cadeia de suprimentos englobando fornecedores e } \\
\text { clientes. } \\
\text { Caracterizado pelo fornecimento de produtos de alta qualidade: } \\
\text { - Compartilhamento total de informações sobre os produtos, processos e } \\
\text { - } \quad \text { alterações nas especificações; } \\
\text { - } \quad \text { Focrmuta de tecnologia e apoio ao design; } \\
\text { Foctratégia e no estabelecimento de parcerias de longo prazo. }\end{array}$ \\
\hline
\end{tabular}

Fonte: adaptado de Stevens (1989).

\subsubsection{Problemas na SCM}

A administração integrada da cadeia de suprimentos é uma tarefa complexa: os recursos envolvidos são elevados, o tempo de implantação é longo, exige mudanças profundas nas organizações, comprometimento entre os parceiros, além de uma infra-estrutura técnica altamente sofisticada.

Davis (1993) descreve alguns fatores que podem dificultar a gestão da cadeia de suprimentos:

- Número de participantes: cada membro tem diferentes políticas de gestão, planejamento, etc. Assim, um elevado número de participantes aumenta a complexidade da cadeia e, conseqüentemente, as incertezas, a probabilidade da ocorrência de atrasos e piora a qualidade das informações. 
- Complexidade da estrutura: cada participante está conectado a vários outros, estabelecendo uma rede complexa e dificultando o planejamento e operação da cadeia. A atual tendência de customização em massa piora este quadro, já que exige materiais, processos de produção e canais de distribuição capazes de atender individualmente os consumidores.

- Incertezas que podem estar relacionadas a:

- Custo, eficiência, tempo de produção, etc.

- Custo e tempo de transporte e estabilidade dos fornecedores.

- Comportamento dos consumidores.

- Atrasos:

- Nos fluxos dos produtos decorrentes do tempo necessário para atendimento dos pedidos, volume dos pedidos ou baixo estoque de segurança. Como precaução, as empresas mantêm altos níveis de estoque, elevando os custos de manutenção.

- Para reagir às mudanças de mercado decorrentes, sobretudo, de atrasos na reposição de estoque ou da informação.

- Nas informações sobre alterações no mercado. A informação pode se propagar formalmente - de forma imediata - através de telefone ou TI, ou informalmente, através da observação dos fluxos dos produtos finais ou partes. Neste último caso há uma defasagem entre a situação de mercado e a propagação da informação.

- Qualidade da informação: é critica para que os administradores possam tomar decisões corretas. Os principais problemas identificados foram: imprecisão e atraso nas informações.

O quadro 2 estabelece as relações entre cada um destes fatores negativos e os principais objetivos da SCM. 


\section{Quadro 2}

Relação entre fatores negativos e os objetivos da SCM

\begin{tabular}{|c|c|c|c|c|c|}
\hline \multirow{2}{*}{ Objetivos } & \multicolumn{5}{|c|}{ Fatores } \\
\hline & $\begin{array}{c}\mathrm{N}^{\mathrm{o}} \cdot \mathrm{de} \\
\text { organizações }\end{array}$ & $\begin{array}{c}\text { Estrutura da } \\
\text { Rede }\end{array}$ & Incertezas & Atrasos & $\begin{array}{l}\text { Qualidade da } \\
\text { Informação }\end{array}$ \\
\hline Desenho mais eficiente & $\mathrm{x}$ & $\mathrm{x}$ & & & \\
\hline $\begin{array}{l}\text { Ampliar conhecimento sobre os } \\
\text { clientes }\end{array}$ & & & & $\mathrm{x}$ & $\mathrm{x}$ \\
\hline $\begin{array}{l}\text { Melhorar o desenvolvimento de } \\
\text { produtos }\end{array}$ & & & $\mathrm{x}$ & $\mathrm{x}$ & $\mathrm{x}$ \\
\hline Elevar a satisfação dos clientes & $\mathrm{x}$ & & $\mathrm{x}$ & $\mathrm{x}$ & $\mathrm{x}$ \\
\hline $\begin{array}{l}\text { Crescimento da cadeia como } \\
\text { um todo }\end{array}$ & $\mathrm{x}$ & $\mathrm{x}$ & $\mathrm{x}$ & & \\
\hline $\begin{array}{l}\text { Ampliar participação no } \\
\text { mercado }\end{array}$ & $\mathrm{x}$ & $\mathrm{x}$ & $\mathrm{x}$ & & \\
\hline $\begin{array}{c}\text { Melhorar a eficiência da } \\
\text { operação }\end{array}$ & $\mathrm{x}$ & $\mathrm{x}$ & $\mathrm{x}$ & $\mathrm{x}$ & \\
\hline $\begin{array}{c}\text { Otimizar globalmente as } \\
\text { operações }\end{array}$ & $\mathrm{x}$ & $\mathrm{x}$ & & & \\
\hline $\begin{array}{l}\text { Responder rapidamente ao } \\
\text { mercado }\end{array}$ & $\mathrm{x}$ & & & $\mathrm{x}$ & $\mathrm{x}$ \\
\hline Ampliar controle do estoque & $\mathrm{x}$ & & $\mathrm{x}$ & $\mathrm{x}$ & \\
\hline $\begin{array}{c}\text { Ampliar taxa de utilização dos } \\
\text { ativos }\end{array}$ & $\mathrm{X}$ & & & & \\
\hline
\end{tabular}

Fonte: adaptado de Davis (1993).

SCM é uma tarefa complexa e exige mudanças profundas nas organizações. Turban, Lee, King e Chung (2002) apontam como fatores que contribuem para o sucesso da SCM:

- Compreensão, por parte da empresa, da dimensão das mudanças;

- Apoio da alta administração e compromisso da organização;

- Consenso, entre os parceiros, quanto aos processos considerados estratégicos e a forma de administrá-los;

- Recursos e poder para garantir as metas.

\subsection{Estrutura conceitual para SCM}

Cooper, Lambert e Pagh (1997) propõem uma estrutura conceitual para SCM composta por três elementos fortemente relacionados: processos de negócio, componentes de gestão e estrutura da cadeia de suprimentos. 
- Processos de negócio são as atividades que produzem valor para o cliente. Englobam as funções internas da empresa, como também as verificadas entre empresas da cadeia de suprimentos.

- Componentes de gestão são os elementos por meio dos quais os processos de negócios são estruturados e administrados.

- Estrutura da cadeia de suprimentos é a configuração das empresas na cadeia.

Segue um detalhamento de cada elemento da estrutura.

\subsubsection{Processos na cadeia de suprimentos}

Davenport (1994) define processo como uma seqüência de procedimentos, estruturados e mensuráveis, que visa produzir um produto ou serviço para um dado cliente ou mercado. Laudon e Laudon (2004) como a forma como são executados e gerenciados os fluxos de materiais, produtos, informação e conhecimentos necessários para realizar as atividades.

Os processos estabelecem uma estrutura de ação. O Center for Competitive Excellence identificou sete processos de negócio:

1. Gestão de relacionamento com clientes: envolve a identificação dos clientes e mercados estratégicos e o desenvolvimento e implantação de programas,

2. Gestão do serviço ao cliente: estabelece interface com o cliente oferecendo informações atualizadas sobre pedidos, disponibilidade, produção e distribuição dos produtos.

3. Gestão da demanda: busca realizar previsões e reduzir a variabilidade por meio da interrelação entre o fluxo de material e de produtos, e a demanda dos clientes.

4. Atendimento de pedido: busca atender aos pedidos dos clientes de forma eficiente, evitando erros e atrasos.

5. Gestão do fluxo de produção: tem como objetivo produzir o que os clientes desejam. Exige processos mais flexíveis e a definição do mix correto de produtos.

6. Suprimentos: busca apoiar o fluxo de produção e o desenvolvimento de novos produtos.

7. Desenvolvimento e comercialização de novos produtos: é crítico para o sucesso das empresas. A integração de clientes e fornecedores estratégicos no desenvolvimento de novos produtos pode reduzir o tempo necessário para colocação no mercado.

O Global Supply Chain Forum acrescentou mais um elemento aos sete descritos anteriormente:

8. Gestão de retorno: busca administrar a devolução dos produtos pelos clientes. 
Os oito processos de negócios cobrem toda a extensão da cadeia e estão na base da implantação da SCM (CROXTON; GARCIA-DASTUGUE; LAMBERT; ROGERS, 2001). O primeiro passo é o estabelecimento de consenso entre os agentes quanto aos processos que devem ser integrados e a forma como serão executados e, finalmente, um roteiro para implantação.

\subsubsection{Componentes de gestão}

Cooper, Lambert e Pagh (1997) partem da premissa que alguns componentes são comuns a todos os processos de negócios e agentes da cadeia. A gestão destes componentes é que determina como os processos de negócios e, conseqüentemente, a própria cadeia de suprimentos, serão estruturados e administrados.

Os autores sugerem dez componentes divididos em dois grupos: componentes físicos e técnicos e componentes gerenciais e culturais.

\subsubsection{Componentes físicos e técnicos}

Os componentes físicos e técnicos são visíveis, tangíveis, mensuráveis e facilmente alteráveis. São eles:

1. Planejamento e controle das operações: ajudam as organizações ou cadeias de suprimentos a moverem-se na direção desejada. O planejamento indica a direção a ser seguida e o controle avalia se o objetivo está sendo atingido. O planejamento é importante para uma gestão de sucesso. O controle para avaliar o desempenho da cadeia de suprimentos.

2. Estrutura de operação: indica como as empresas desempenham suas tarefas e atividades.

3. Estrutura organizacional: pode indicar empresas individuais ou a cadeia de suprimentos. $\mathrm{O}$ nível de integração dos processos através da cadeia pode ser uma medida da estrutura organizacional.

4. Estrutura para o fluxo de produtos: refere-se à estrutura em rede que permite abastecer, produzir e distribuir produtos através da cadeia de suprimentos. A racionalização das redes afeta todos os agentes.

5. Estrutura para o fluxo de informação: refere-se à estrutura em rede que possibilita o fluxo da informação. Informações precisas e atualizadas têm forte influência na eficiência da cadeia. 
6. Estrutura do produto: inclui a coordenação do desenvolvimento de novos produtos através da cadeia e do portfólio de produtos. Produtos mais complexos exigem um número maior de fornecedores e, portanto, dificultam a integração.

\subsubsection{Componentes gerenciais e culturais}

Os componentes gerenciais e culturais definem o comportamento da organização e influenciam a implantação dos componentes físicos e técnicos. São menos tangíveis e visíveis e mais difíceis de serem alterados.

7. Métodos de gestão: incluem a filosofia corporativa e as técnicas de gestão. $\mathrm{O}$ estabelecimento de uma cultura corporativa e compatibilidade entre os membros são fundamentais para a integração da cadeia.

8. Estrutura de liderança e poder: afeta a forma da cadeia e o nível de comprometimento entre os membros. Varia de transacional até relacionamento cooperativo. Um canal de liderança forte determinará a direção da cadeia.

9. Estrutura de partilha de riscos e recompensas: define a divisão dos riscos e compensações entre os membros da cadeia e pode afetar o comprometimento de longo prazo dos agentes.

10. Cultura corporativa e atitude: as culturas corporativas devem ser compatíveis quando se deseja implantar e atingir uma meta convergente na cadeia de suprimentos. Muitas divergências operacionais decorrem do uso de diferentes terminologias.

\subsubsection{Estrutura da cadeia de suprimentos}

As empresas, de forma geral, atuam em várias cadeias de suprimentos simultaneamente configurando uma rede. Mas nem todos os agentes e elos da rede precisam ser integrados e coordenados.

Para definir a parte que será gerenciada é central compreender quem são os agentes estratégicos da cadeia e por quais processos estão interligados. A definição dos agentes e elos estratégicos depende de fatores tais como: complexidade do produto, número de fornecedores disponíveis e disponibilidade de matéria prima (SPENS; BASK, 2002).

Spens e Bask (2002) apontam três aspectos da estrutura que devem ser analisados para a definição da parte da rede que será administrada: agentes da cadeia, dimensão estrutural e processos entre os agentes da cadeia. 
1. Agentes da cadeia: identificar e determinar sua importância estratégica para a empresa e para a cadeia.

2. Dimensão estrutural da rede:

- Estrutura horizontal - identificar os elos na cadeia;

- Estrutura vertical - identificar os fornecedores e clientes de cada elo;

- Posição horizontal - localizar a empresa na cadeia.

3. Tipos de processo entre os agentes:

- Gerenciais: integram o processo de uma empresa a um ou mais fornecedores ou clientes. Integração e coordenação são fundamentais.

- Monitorados: não são tão críticos como os gerenciais, mas sua integração e coordenação são importantes.

- Não-gerenciais e não-membros: não exigem monitoramento já que a empresa não mantém relação direta com eles.

A partir desta estrutura conceitual, Cooper, Lambert e Pagh (1997) propõem o modelo representado na figura abaixo. O modelo contempla todos os elementos da estrutura conceitual e pode ser utilizado pelos executivos como ferramenta de apoio para implantação da SCM. 
Figura 4 - Estrutura para Gestão da Cadeia de Suprimentos

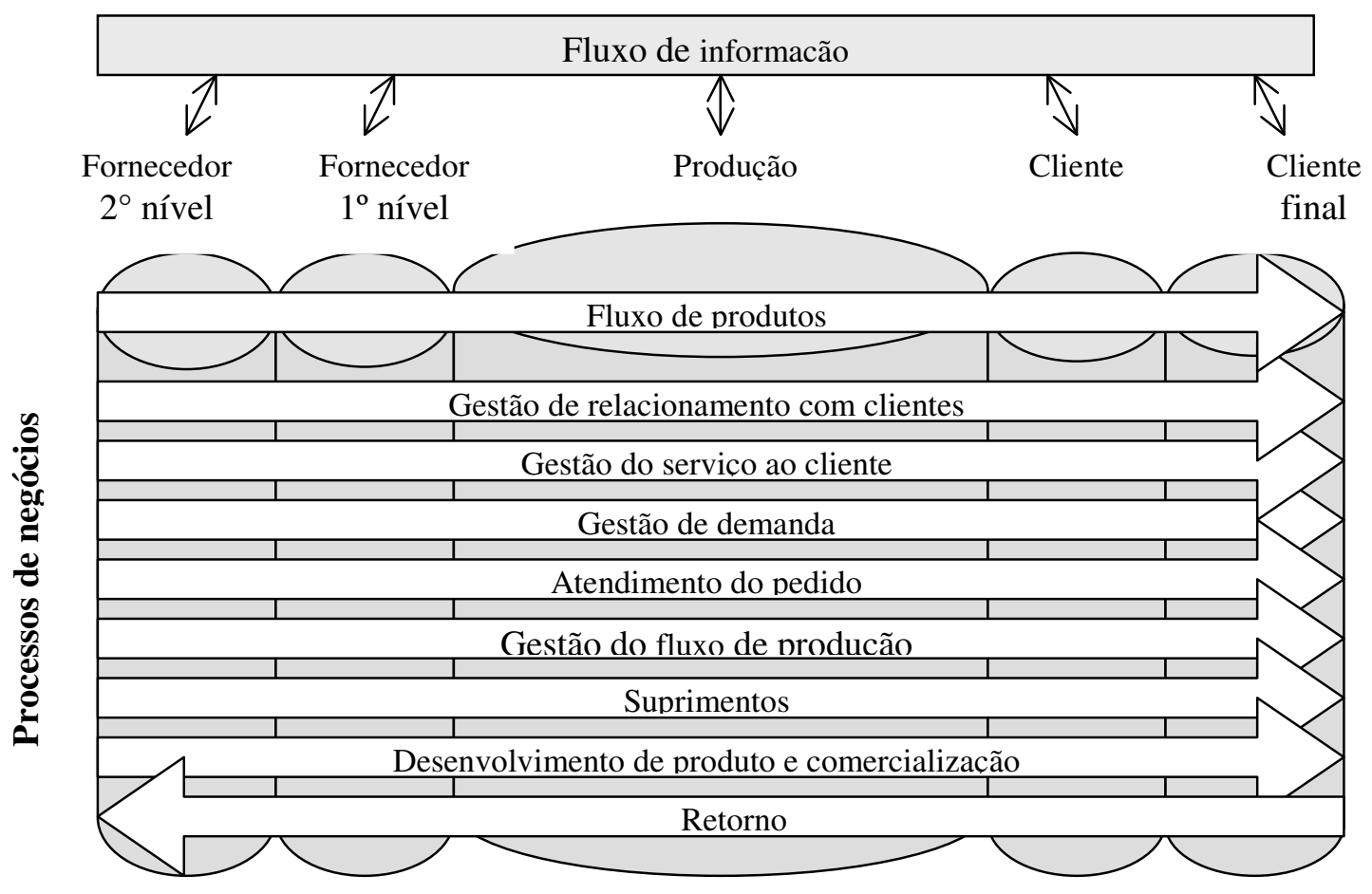

Componentes de gestão

- Planejamento e controle

- Estrutura de funcionamento

- Estrutura da organização

- Estrutura para facilitar o fluxo de produtos

- Estrutura para facilitar o fluxo de informação
- Estrutura do Produto

- Métodos de gestão

- Estrutura de poder e liderança

- Estrutura de risco e recompensa

- Cultura e comportamento

Fonte: Cooper, Lambert e Pagh (1997, p. 10).

\section{$\mathbf{X}-\mathbf{X}-\mathbf{X}$}

A SCM vem sendo confundida, muitas vezes, com a logística integrada. Mas, SCM abrange um conjunto de processos de negócio que ultrapassa as atividades diretamente ligadas à logística (LAMBERT; STOCK, 1998). Envolve planejamento, organização, coordenação e controle de diferentes unidades, parceiros e atividades, combinação de várias técnicas, além do uso intensivo da tecnologia da informação (TURBAN; LEE; KING; CHUNG, 2002).

A logística integrada restringe-se à administração dos fluxos e estoques de materiais, produtos e informação entre os agentes da cadeia. Garante a sincronização e continuidade das 
atividades entre os parceiros e atividades, evitando falhas e interrupções (TURBAN; RAINER; POTTER, 2003).

A logística integrada é, portanto, parte importante da gestão da cadeia de suprimentos e está nos fundamentos da sua implantação. Para Bowersox, Closs e Stank (1999) existe uma clara necessidade de integração e coordenação dos fluxos de materiais, produtos, informação e recursos para a implantação da gestão da cadeia de suprimentos.

No próximo capítulo serão apresentados e discutidos os conceitos de logística e de logística integrada. 


\section{CAPÍTULO 3 LOGÍSTICA E LOGÍSTICA INTEGRADA}

\subsection{Definição de logística}

A logística pode ser entendida como a função responsável pelos fluxos e armazenagem de material, produtos e informação dentro das empresas. Mas, também, como um conceito mais amplo, responsável pelos fluxos e armazenagem entre os agentes da cadeia de suprimentos (MENTZER; MIN; BOBBITT, 2004).

A definição de logística adotada pelo Council of Supply Chain Management Professionals (CSCMP) é abrangente. Logística é a parte do processo da cadeia de suprimento que planeja, implanta e controla o fluxo e armazenagem de bens, serviços e informações, de forma eficiente e eficaz, desde a aquisição de matéria prima até o consumo final.

A logística é eficaz quando atende adequadamente às exigências operacionais. E eficiente quando atinge a eficácia com a menor quantidade possível de recursos. Portanto, eficiência está relacionada com a quantidade de recursos necessária para atingir a eficácia (BOWERSOX; CLOSS, 2001).

O objetivo da logística é - por meio do estabelecimento de fluxos de materiais, produtos e informação entre os diversos agentes da cadeia - dispor o produto ou serviço certo, no lugar certo, no tempo certo e nas condições desejadas.

\subsubsection{Fluxo de materiais e produtos}

O fluxo de materiais compreende a movimentação e armazenagem de matéria prima, componentes e produtos acabados entre as fontes de suprimentos, instalações e compradores da empresa. Tem início com a remessa de materiais pelos fornecedores e termina com a entrega do produto ao comprador final, abrangendo três áreas operacionais - suprimentos, apoio à manufatura e distribuição física - e permeando toda a cadeia de suprimentos. Nas empresas comuns, as três áreas da logística se sobrepõem.

- Suprimento abrange a compra e organização da movimentação de entrada de materiais, peças e produtos acabados para fábricas ou montadores, depósitos ou varejo. Inclui tanto o recebimento como as operações de separação e montagem. Bowersox e Closs (2001) definem materiais como o estoque que está sendo introduzido na empresa e, produto, 
como o estoque disponível para os compradores. Produto é o resultado do valor agregado ao material na produção, separação ou montagem.

- Apoio à manufatura concentra-se no gerenciamento do estoque em processo nas fases de fabricação. Tem como objetivo disponibilizar, em tempo hábil, materiais, componentes e estoque em processo. Voltado para o que é fabricado, quando e onde.

- Distribuição física trata da movimentação dos produtos acabados para entrega aos clientes. Estabelece um canal com os clientes. Tem como objetivo entregar os produtos de maneira eficiente, quando e onde necessário.

Para planejar, implantar e controlar o fluxo de matérias-primas, estoque em processo, produtos acabados e informações, a logística desenvolve uma série de atividades. Atividade são os procedimentos, física e tecnologicamente distintos, que criam valor para os clientes (BOWERSOX; CLOSS, 2001).

No quadro abaixo, Bowersox e Closs (2001) classificaram as atividades de rotina da logística em cada uma das três áreas.

Quadro 3 - Atividades nas áreas de suprimentos, apoio à manufatura e distribuição

\begin{tabular}{|c|c|}
\hline $\begin{array}{l}\text { Suprimentos } \\
\text { Atividades relacionadas à obtenção de produtos e materiais } \\
\text { de fornecedores externos }\end{array}$ & $\begin{array}{l}\text { Execução e planejamento de recursos } \\
\text { Localização de fontes de suprimento } \\
\text { Negociação } \\
\text { Colocação de pedido } \\
\text { Transporte de saída } \\
\text { Recebimento e inspeção } \\
\text { Armazenagem e manuseio } \\
\text { Garantia de qualidade }\end{array}$ \\
\hline $\begin{array}{l}\text { Apoio à manufatura } \\
\text { Atividades relacionadas ao planejamento, programação e } \\
\text { apoio às operações de produção. }\end{array}$ & $\begin{array}{l}\text { Planejamento do programa mestre } \\
\text { Execução das atividades de armazenagem do } \\
\text { estoque semi-acabado } \\
\begin{array}{l}\text { Manuseio, transporte e separação de } \\
\text { componentes. }\end{array}\end{array}$ \\
\hline $\begin{array}{l}\text { Distribuição física } \\
\text { Atividades relacionadas com fornecimento de serviço ao } \\
\text { cliente }\end{array}$ & $\begin{array}{l}\text { Recebimento e processamento dos pedidos } \\
\text { Posicionamento dos estoques } \\
\text { Armazenagem e manuseio } \\
\text { Transporte no canal de distribuição. }\end{array}$ \\
\hline
\end{tabular}

Fonte: adaptado de Bowersox e Closs (2001).

As empresas não realizam o total das atividades logísticas, mas apenas aquelas necessárias para o desenvolvimento de seu negócio. Um fabricante de automóveis, por exemplo, deve oferecer um serviço de reparo e peças para substituição, mas não precisa de serviço de embalagem.

As atividades logísticas podem ser combinadas de várias maneiras. Cada combinação resulta em um dado custo e num determinado nível de serviço ao cliente. Se a rapidez na 
entrega do produto é importante, a empresa deve utilizar meios de transporte mais rápidos e, portanto, mais caros. Se utilizar meios de transporte mais baratos e, consequentemente, mais lentos e menos confiáveis, deve manter estoques maiores para enfrentar as incertezas.

Toda atividade inclui componentes físicos e de informação. Componentes físicos são todos os materiais necessários para o desenvolvimento das atividades. Informação abrange a captação, manipulação e distribuição dos dados necessários ao desenvolvimento das atividades (PORTER; MILLAR, 1985).

As três áreas operacionais geram e utilizam informações. Estas informações permitem que as empresas identifiquem as necessidades do processo, e planejem e executem as operações logísticas de forma integrada.

\subsubsection{Fluxo de informação}

Bowersox e Closs (2001) classificam as informações logísticas em: de planejamento e coordenação e operacionais. A figura 5 descreve seus fluxos e relações.

Figura 5 - Necessidades de informações logísticas

Relação entre os fluxos de planejamento e operacional

Fluxo de informações de planejamento e coordenação

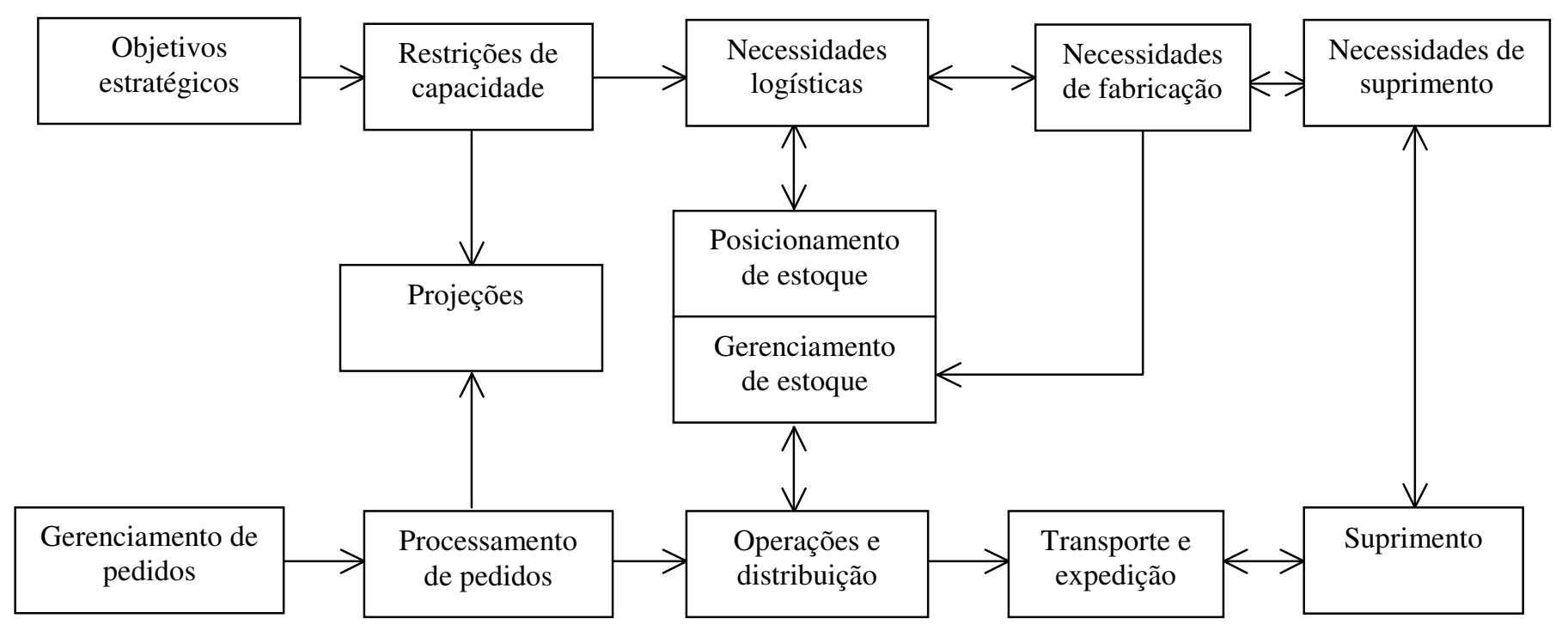

Fluxo de informações operacionais

Fonte: Bowersox e Closs (2001, p. 47). 


\subsubsection{Fluxo de informação de planejamento e coordenação}

O fluxo das informações de planejamento e coordenação atende ao planejamento da empresa. Inclui informações como: objetivos estratégicos, restrições de capacidade, necessidades logísticas, posicionamento do estoque, necessidades de fabricação, necessidades de suprimento e projeções (BOWERSOX; CLOSS, 2001):

- Objetivos estratégicos são os principais propulsores de toda a cadeia. Identificam a natureza e a localização dos compradores e os produtos e serviços a serem oferecidos.

- Restrições de capacidade determinam as necessidades internas e externas de fabricação. Em função dos objetivos estratégicos, identificam o nível de utilização das instalações as eventuais barreiras, limitações ou gargalos da produção - e a necessidade de terceirização.

- Necessidades logísticas: determinam o trabalho que a mão de obra, equipamento e distribuição devem executar para atender o mercado. O desempenho esperado é determinado por informações extraídas das previsões, pedidos de clientes, nível de estoque e programação de promoções.

- Posicionamento do estoque (composição e localização): é determinado pela interface entre os dois fluxos e deve ser capaz de atender adequadamente as necessidades ao longo da cadeia (o que, onde e quando). A partir de uma necessidade logística executa-se um plano de produção que resultará em um posicionamento do estoque.

- Necessidade de suprimento: é determinada pela quantidade de componentes e materiais para atender as necessidades da produção. Cabe à função suprimento coordenar o relacionamento da empresa com fornecedores.

- Previsões: são baseadas em dados históricos e no nível atual de atividade. Fundamentam os planos operacionais e de necessidades logísticas.

\subsubsection{Fluxo de informação operacional}

O fluxo de informação operacional atende a execução do trabalho de rotina da logística. Inclui: gerenciamento e processamento dos pedidos, distribuição, gerenciamento de estoque, expedição e transporte, e suprimentos. O papel da TI é central (BOWERSOX; CLOSS, 2001):

- Gerenciamento de pedidos: dar entrada e qualificar os pedidos dos clientes. Exige transmissão de informações entre os membros da cadeia de suprimentos que é realizada 
através de telefone, correio, fax ou eletronicamente, utilizando ferramentas como EDI (Electronic Data Interchange).

- Processamento de pedidos: avaliar os estoques e distribui tarefas para atender aos clientes. A TI permite a ligação entre compradores e fornecedores em tempo real.

- Distribuição: armazenar e manusear o menor estoque possível para atender aos compradores. Manter o nível adequado de sortimentos através de uma programação da disponibilidade. Exige informações para o uso adequado das instalações logísticas.

- Gerenciamento de estoque: assegurar que todo o sistema logístico disponha dos recursos adequados para atender o planejamento. $\mathrm{O}$ posicionamento do estoque e o seu gerenciamento exigem recursos humanos e TI.

- Transporte e expedição: consolidar pedidos, garantir a disponibilidade no momento adequado e elaborar a documentação.

- Suprimento: elaborar e liberar pedidos de compra. Utiliza o mesmo tipo de informação do processamento de pedidos.

As informações operacionais devem apoiar o trabalho de rotina da logística: suprimentos, apoio à manufatura e distribuição física. As informações de planejamento, por sua vez, devem apoiar o planejamento das atividades.

\subsection{Trabalho logístico}

O trabalho logístico envolve a execução e coordenação das atividades necessárias para atender as exigências logísticas. A execução refere-se às operações de movimentação e armazenagem de materiais, componentes semi-acabados e produtos acabados entre as fontes de suprimento, instalações e os compradores da empresa. A coordenação, por sua vez, à gestão do trabalho de maneira orquestrada visando gerar a capacidade necessária para atendimento das necessidades logísticas (BOWERSOX; CLOSS, 2001).

Bowersox e Closs (2001) classificam o trabalho logístico em cinco áreas distintas: projeto de rede, transporte, controle de estoque, armazenagem, manuseio de materiais e embalagens, e informação.

\subsubsection{Projeto de rede}

Projeto de rede é a definição das instalações necessárias para a execução do processo logístico, o tipo de estoque e o volume a ser armazenado em cada instalação, além de 
estabelecer os vínculos dos pedidos dos clientes aos locais de expedição. A rede de instalações forma a estrutura que permite o processamento dos pedidos, manutenção de estoque e operação de materiais. Deve ser flexível para se adaptar às diferenças geográficas e alterações na demanda e é importante para o desempenho competitivo.

\subsubsection{Controle do estoque}

Segundo a Associação Brasileira de Movimentação e Logística (ABML), estoque são todos os bens e materiais mantidos por uma organização para suprir a demanda futura. Controle de estoque são as atividades e procedimentos que permitem garantir a quantidade adequada de cada item. O controle obedece, no geral, aos critérios definidos pelos próprios clientes e sua eficiência está associada a quantidade, custo de manutenção, número de vezes por período onde ocorre falta de um item, giro do estoque e qualidade do serviço oferecido ao cliente.

A necessidade de estoque depende da estrutura de rede e do nível do serviço desejado. Deficiências na rede logística podem ser compensadas pela manutenção de níveis mais altos de estoque, embora resultando em maiores custos. O objetivo da gerência de estoque é a máxima rotatividade satisfazendo os compromissos com os compradores.

Para estabelecer uma política adequada de estoque é preciso observar:

- Segmentação dos clientes: a empresa deve planejar seus estoques visando seus clientes preferenciais, isto é, clientes com potencial de crescimento e alta lucratividade. Estes clientes são definidos a partir dos produtos adquiridos, volume, preços, serviços de valor agregado e atividades complementares necessárias para o desenvolvimento e manutenção de fidelidade.

- Características dos produtos: os produtos têm volumes de venda e lucratividade diferentes. Mesmo quando os volumes de venda e lucratividade são baixos, devem ser mantidos em estoque para atender aos clientes preferenciais. A identificação destes produtos permite o desenvolvimento de uma política seletiva de estoque.

- Transporte: seu desempenho é afetado diretamente pela definição dos itens que serão armazenados em cada instalação. Estoques centralizados permitem a consolidação da carga por cliente ou localidade geográfica. O preço do transporte é determinado pelo volume e dimensões da carga e pela distância percorrida. Um custo menor de transporte pode compensar um custo superior para manutenção de estoque 
- Agilidade: maior precisão e agilidade no atendimento às necessidades dos clientes permitem a redução dos estoques e aumento da satisfação. Mas, em contrapartida, elevam o custo porque exigem entregas mais freqüentes e em menor volume. A questão é encontrar o equilíbrio entre nível de serviço oferecido e o custo logístico total.

- Desempenho competitivo: uma política de estoque adequada permite que a empresa supere a concorrência. A manutenção de estoques elevados garante disponibilidade do produto e rapidez na entrega, proporcionando um serviço de melhor qualidade.

\subsubsection{Transporte}

Posiciona geograficamente o estoque. O desempenho do transporte pode ser medido pelo custo, velocidade e consistência. Custo é composto pelas despesas de deslocamento, gerenciamento e manutenção do estoque em trânsito. Velocidade é o tempo necessário para realizar uma movimentação. E consistência é a manutenção de padrão de tempo para as movimentações.

Não havendo consistência é preciso manter estoques maiores para se proteger de eventuais atrasos. Custo e velocidade estão relacionados: quanto mais rápido o transporte, mais caro é o serviço, mas menor o tempo de trânsito e a indisponibilidade do estoque. A velocidade e consistência, por sua vez, são atributos observados pelo usuário para definir a qualidade do transporte. A empresa deve buscar a combinação entre custo e velocidade e entre custo e qualidade do serviço que melhor atenda ao negócio e as suas metas estratégicas.

\subsubsection{Armazenagem, manuseio de materiais e embalagem.}

As três funções têm importante papel na logística. Quando integradas simplificam e aumentam a velocidade do fluxo de produtos ao longo de todo o sistema.

- Armazenagem: permite manter materiais ou produtos, secos ou refrigerados, em instalações adequadas. Os materiais e produtos podem ser alfandegados, no caso de terem como origem ou destino o exterior, ou não alfandegados, no caso da origem e destino estarem no território nacional (ABML).

- Manuseio: os produtos devem ser recebidos, movimentados, separados e agrupados para atender as necessidades dos compradores. O manuseio incorreto pode ocasionar avarias nos produtos. 
- Embalagem: permite manusear os produtos de forma mais eficiente. Os produtos são, geralmente, agrupados em unidades maiores. A unidade inicial é a caixa mestra que, depois, é consolidada em unidades maiores (tais como pallets, slip sheets e diversos tipos de contêineres).

\subsubsection{Informação}

O processo logístico engloba, além dos fluxos e estoques de materiais e produtos, o fluxo de informação. A logística deve garantir, a partir das informações, a disponibilidade dos produtos e serviços no tempo, local e quantidade certos. Seu desempenho depende, portanto, da capacidade para controlar e explorar os fluxos de informação associados à movimentação de materiais e produtos.

Informações imprecisas ou de má qualidade podem criar inúmeros problemas operacionais, sobretudo para as áreas de gerenciamento de pedidos e projeções. A projeção tem como objetivo calcular as necessidades futuras e, desta forma, orientar o posicionamento do estoque para atender aos clientes. O gerenciamento de pedidos, por sua vez, envolve todos os aspectos relativos à gestão das necessidades dos clientes, desde o pedido até a entrega da mercadoria.

O acesso à informação precisa e atualizada é, portanto, fator chave para as operações logísticas: pode ajudar a diminuir as imprecisões e a buscar a sincronização entre demanda e oferta ao longo da cadeia, garantindo que o produto esteja continuamente em movimento, mantendo os estoques no menor nível possível.

\subsection{Processo logístico}

A forma como são executados e gerenciados os fluxos de materiais, produtos e informação necessários para atender as necessidades dos clientes é denominado processo logístico (LAUDON; LAUDON, 2004; BOWERSOX; CLOSS, 2001).

O processo logístico tem início na remessa dos materiais e componentes pelos fornecedores e termina na entrega do produto ao cliente final. A partir da compra de materiais e componentes, o processo logístico movimenta os fluxos agregando valor. Assim, para estudar o processo logístico é necessário mapear os fluxos de materiais, produtos e informação que ocorrem entre os agentes. 
Os fluxos se desenvolvem nos canais de distribuição. Canal é o meio pelo qual ocorre a transferência de propriedade dos produtos e serviços entre os agentes. A estrutura do canal é formada pelo grupo de agentes - do fornecedor até o comprador final - que assume a propriedade ou viabiliza a troca de produtos e serviços no processo de comercialização (BOWERSOX; CLOSS, 2001).

A figura abaixo representa a estrutura genérica de um canal de distribuição

\section{Figura 6 - Canais genéricos de distribuição}

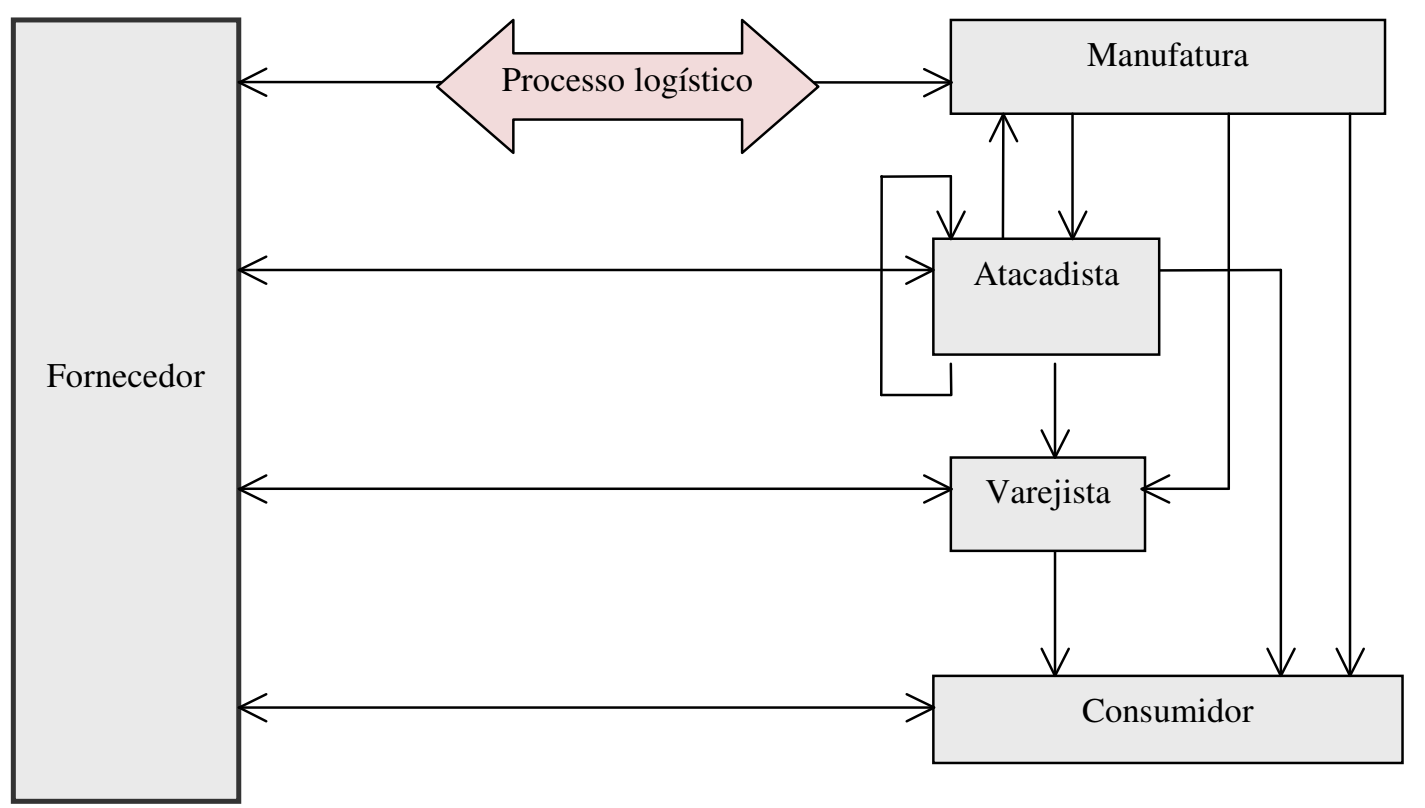

Fonte: adaptado de Bowersox e Closs (2001).

Os fluxos podem ocorrer em vários sentidos e direções. Os varejistas, por exemplo, podem transacionar diretamente com todos os níveis anteriores: atacadistas, fabricantes e fornecedores. Uma empresa pode vender diretamente ao consumidor final, sem ser intermediada por atacadistas ou varejistas. Ou, ainda, um atacadista pode intermediar o fluxo de produtos entre duas manufaturas (BOWERSOX; CLOSS, 2001).

\subsubsection{Ciclos de atividades}

Bowersox e Closs (2001) dividem o processo logístico em três ciclos: distribuição física, apoio à manufatura e suprimentos. O ciclo de apoio à manufatura desenvolve-se, 
geralmente, dentro das empresas; o de suprimentos liga a empresa aos fornecedores e, finalmente; o de distribuição liga a empresa aos compradores. Os ciclos de suprimentos e distribuição estabelecem, portanto, as interfaces entre a empresa e seus parceiros externos. A figura 7 representa os três ciclos.

\section{Figura 7 - Ciclos de atividades}

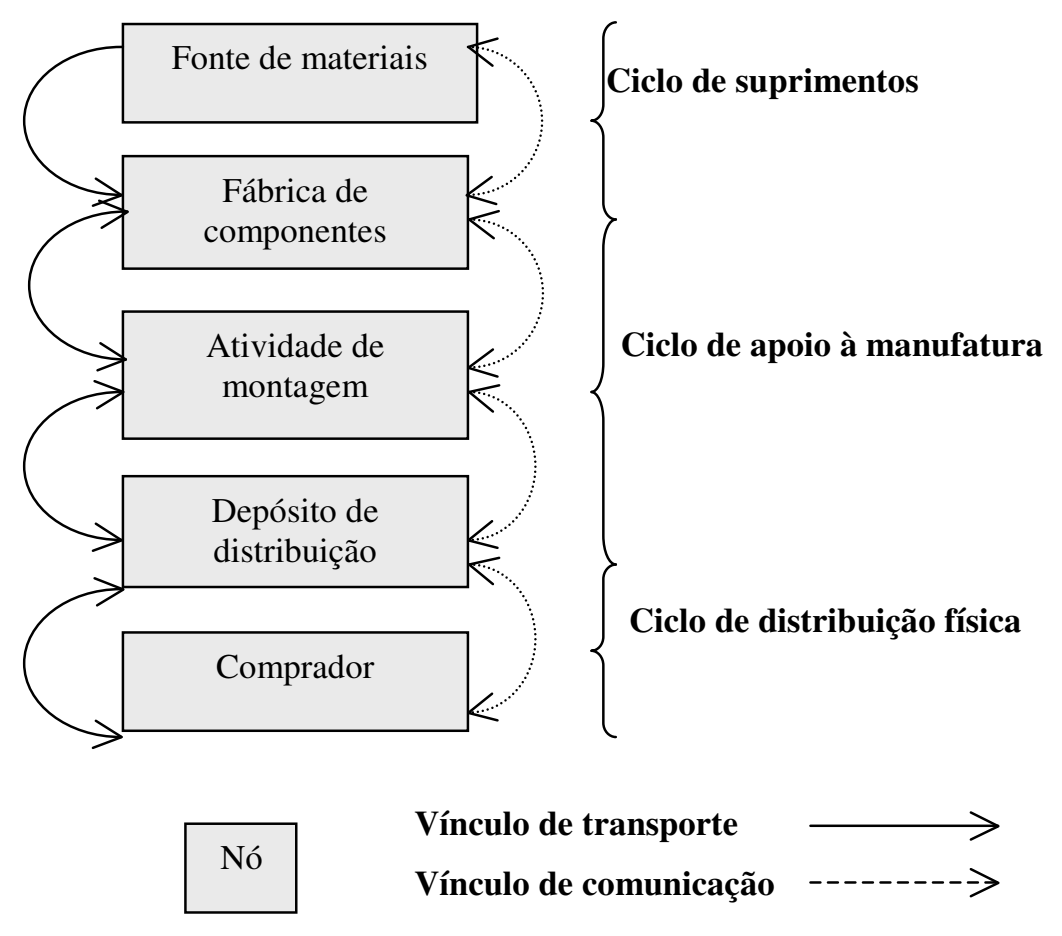

Fonte: Bowersox e Closs (2001, p. 55).

Os três ciclos de atividades estão interligados e permeiam toda a cadeia de suprimentos. A figura abaixo indica os três ciclos de um processo logístico ligando o fornecedor à manufatura. 
Figura 8 - Ciclos de atividades no processo logístico entre fornecedor e manufatura

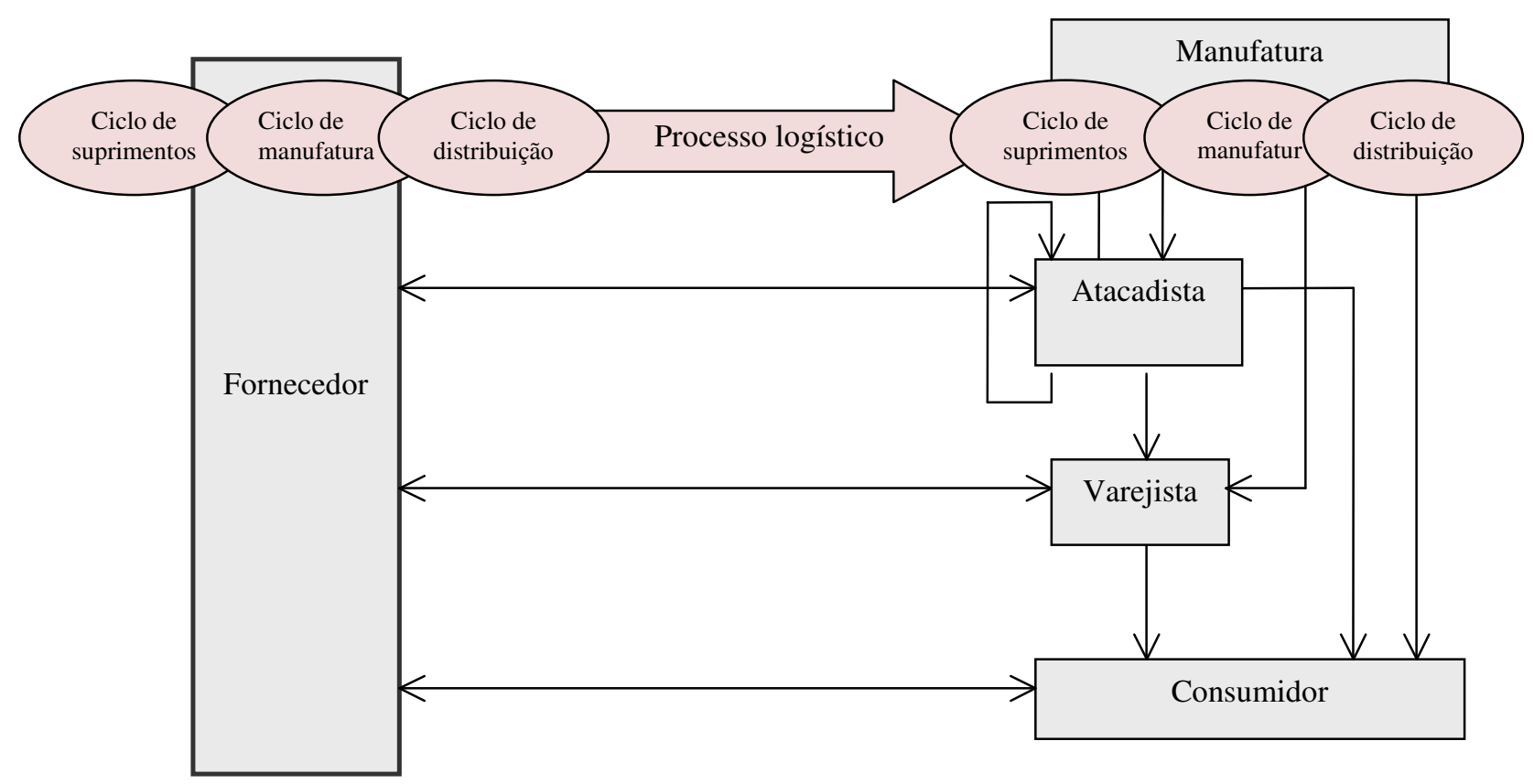

Fonte: adaptado de Bowersox e Closs (2001).

O ciclo de suprimentos movimenta um fluxo de bens de valor agregado que finaliza no ciclo de distribuição física, quando ocorre a transferência do produto acabado para o comprador. O ciclo de distribuição do vendedor está conectado ao ciclo de suprimentos do comprador. Portanto, "os ciclos de atividades envolvem toda a cadeia de suprimentos e estabelecem vínculos entre as empresas participantes" (BOWERSOX; CLOSS, 2001, p. 54).

O resultado esperado da gestão dos três ciclos de atividades é satisfação das necessidades logísticas. Mas, o desempenho global depende da operação de cada um deles individualmente. A seguir, serão detalhados os três ciclos de atividades.

\subsubsection{Ciclos de atividades da distribuição física}

O ciclo de distribuição física tem inicio com a expectativa de venda ou os pedidos dos clientes. Abrange desde o processamento dos pedidos até a entrega das mercadorias. $\mathrm{O}$ objetivo é disponibilizar os produtos no tempo correto e ao preço adequado. O ciclo é composto pelas seguintes atividades: transmissão, processamento e separação dos pedidos, transporte e entrega ao cliente. Estas operações são denominadas logística de saída. 
Figura 9 - Atividades de distribuição física

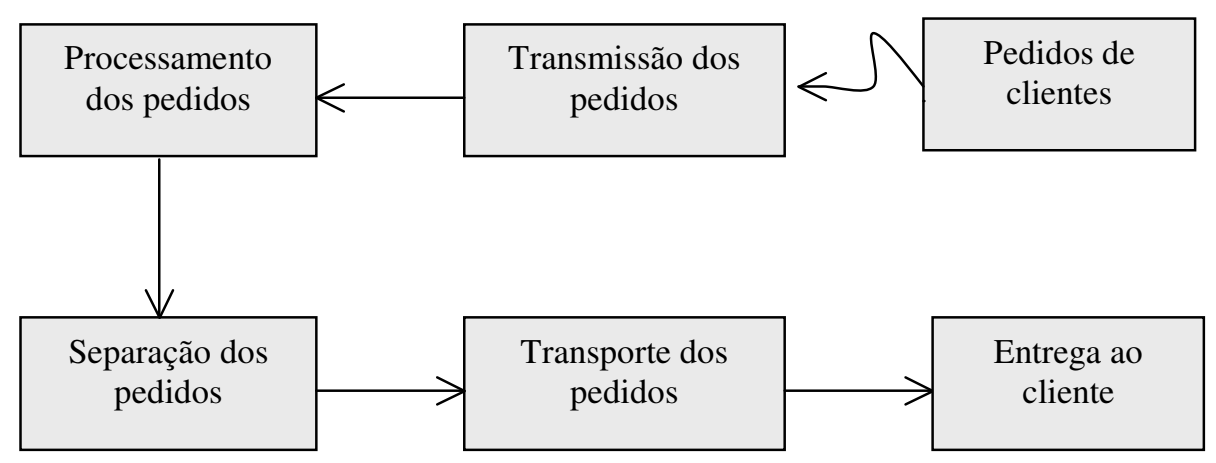

Fonte: Bowersox e Closs (2001, p. 57).

O ciclo de distribuição física vincula a empresa aos clientes e, portanto, estabelece uma interface entre as áreas de produção e marketing. O marketing tem como objetivo conquistar e atender clientes. Assim, seu interesse é manter estoques que garantam pronto atendimento. A produção, por sua vez, tem como objetivo controlar custos o que significa operar com o menor nível de estoque possível.

De forma geral, as empresas decidem seus estoques a partir das expectativas futuras de venda e, com frequiência, podem ocorrer erros que se propagam por todo o sistema logístico. Mas, para Bowersox e Closs (2001), o ciclo de distribuição física está mais sujeito a erros porque opera em direção ao mercado final.

A redução dos erros pode ocorrer por meio do aperfeiçoamento das projeções, da coordenação da gestão dos pedidos dos clientes e, por fim, de maior flexibilidade e agilidade no ciclo de distribuição física. Assim, a capacidade de resposta logística da empresa vendedora é central para um bom desempenho (BOWERSOX; CLOSS, 2001).

\subsubsection{Ciclos de atividades de apoio à manufatura}

O objetivo do ciclo de apoio à manufatura é posicionar e coordenar os materiais e estoques dentro das empresas de modo a manter um fluxo adequado para atender a programação da produção. Suas atividades são a movimentação e armazenamento de produtos, materiais, componentes e peças semi-acabadas nas instalações da empresa.

Para enfrentar a crescente concorrência, as empresas vêm operando com ciclos de produção mais curtos e buscando agilidade para efetuar ajustes em suas máquinas. Desta 
forma podem se adequar às mudanças das exigências dos mercados e clientes. Mas, a implantação desta forma de produção exige apoio logístico preciso.

A logística de apoio à produção está restrita exclusivamente à movimentação e armazenagem no processo produtivo. O processo produtivo tem início quando a empresa compra materiais e componentes dos fornecedores e termina quando o produto final está pronto para a venda.

Assim, de forma geral, a logística de apoio à produção refere-se às movimentações internas da empresa. Mas algumas empresas podem operar com diversas unidades especializadas, que desenvolvem atividades específicas. Neste caso, podem ser necessárias operações logísticas complexas, envolvendo inúmeros manuseios e transferências num único processo de produção.

Terminada a produção, o estoque de produtos acabados irá para os compradores ou outros depósitos de distribuição dando início aos ciclos de distribuição física. A movimentação dos produtos finais já faz parte da distribuição física.

\subsubsection{Ciclos de atividades de suprimento}

O objetivo do ciclo de suprimentos é viabilizar a produção de forma estável e contínua. Portanto, deve desenvolver atividades que facilitem o fluxo ordenado de materiais, componentes ou produtos acabados para a produção ou distribuição. As atividades são: seleção de fontes de suprimento, colocação de pedido e expedição, transporte e recebimento. As operações de suprimento são também denominadas logística de entrada.

Figura 10 - Atividades do ciclo de suprimentos

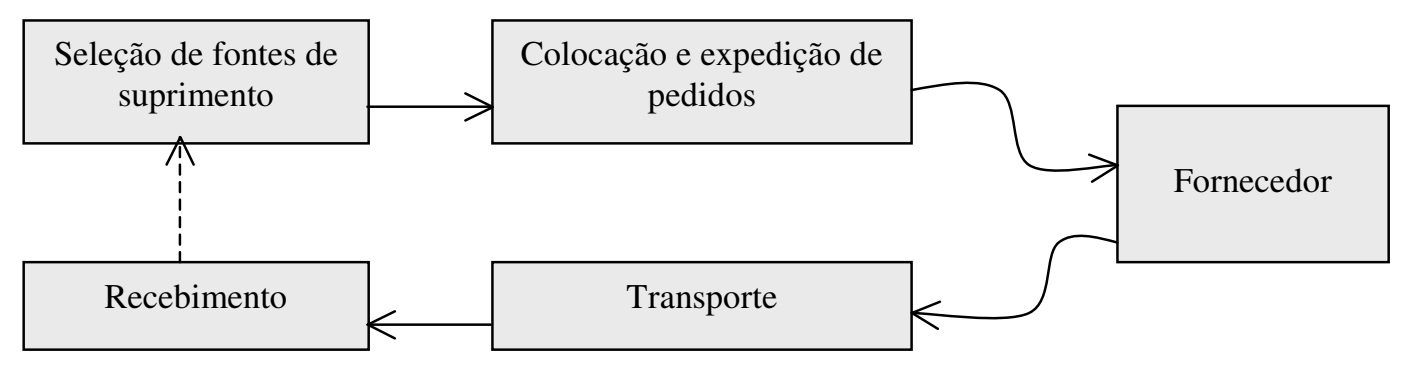

Fonte: Bowersox e Closs (2001, p. 59). 
Cada tarefa dos ciclos exige um período de tempo para ser desenvolvida e está sujeita à diferentes ocorrências, o que pode gerar instabilidades. Assim, incerteza operacional é uma característica estrutural dos ciclos de atividades que é crítica para a logística.

Atrasos ou adiantamentos exigem recursos extras e reduzem a eficiência logística. Atrasos, de forma geral, decorrem de falhas nas operações e tornam necessário o estabelecimento de estoques de segurança. Adiantamentos também exigem o manuseio e armazenagem dos estoques entregues antecipadamente.

\subsubsection{Ciclos de atividades globais}

No caso das cadeias de suprimentos globais, o processo logístico torna-se ainda mais complexo. Bowersox e Closs (2001) apontam as principais diferenças entre a logística restrita aos mercados nacionais e abrangendo mercados internacionais.

1. Duração dos ciclos de atividades

- Os ciclos internacionais são mais longos, menos consistentes e flexíveis que os restritos a um país. Isto devido aos atrasos de comunicação, necessidades de financiamento e de embalagens especiais, programação de linhas marítimas, tempo de transporte e necessidade de desembaraço aduaneiro.

- A comunicação é mais complexa devido às diferenças de fuso horário e de idiomas, exigência de carta de crédito para financiamento, necessidade de embalagens especiais para proteger os produtos de danos no manuseio e das condições adversas existente nos contêineres.

2. Maior complexidade das operações

- Necessidade da utilização de diferentes idiomas nos produtos e documentação. Os autores exemplificam apontando a maior necessidade de estoques - dada à diversidade de idiomas existentes - para operar com a Comunidade Européia. As transações internacionais exigem, ainda, um maior número de documentos.

- Diferenças de características dos produtos nos diferentes países, tais como características de funcionamento, alimentação de energia elétrica, requisitos de segurança, etc.

- Maior complexidade do transporte internacional, sobretudo no transporte marítimo oceânico.

3. Sistemas de informação: maior necessidade de coordenação das operações e, portanto, de integração dos sistemas. 
4. Alianças: maior importância do estabelecimento de alianças, já que permite acesso a mercados e a experiências de terceiros além de reduzir o risco inerente às operações globais.

\subsubsection{Semelhanças e diferenças entre os ciclos de atividades}

Para atingir a consistência, o desafio é projetar ciclos capazes de operar de forma integrada. Planejamento e controle da integração total da logística exigem a compreensão das semelhanças e diferenças existentes entre os três ciclos de atividades.

Bowersox e Closs (2001) apontam três diferenças importantes entre o ciclo de suprimentos e de distribuição que tornam o primeiro mais estável.

Em primeiro lugar, o ciclo de suprimentos opera, de forma geral, com grandes volumes de cargas que exigem meios de transporte como barcaças, navios, trens e caminhões. Além disto, os materiais e componentes têm menor valor que os produtos acabados. Assim, justifica-se a utilização de meios de transporte mais lentos. Os meios de transporte mais rápidos e, portanto, mais caros, são utilizados somente nos casos onde componentes tem alto valor.

Os autores citam como exemplo uma empresa fabricante de massa para bolo e um mecânico de automóveis fora de série. Como a farinha de trigo é um componente barato e utilizado intensivamente na fabricação de bolos, faz sentido para a empresa comprar grandes lotes e despachar por estrada de ferro. Já, no caso do mecânico, seria mais eficiente comprar pequenas quantidades e despachar por um serviço de entrega rápida.

Em segundo lugar, o ciclo de suprimentos opera com um número menor de parceiros. De forma geral, o número de fornecedores de uma empresa é menor que o de clientes. Bowersox e Closs (2001) citam o caso de uma empresa com 6 milhões de clientes e apenas 250 fornecedores. O ciclo de suprimentos é também mais direto: materiais e peças são, normalmente, adquiridos diretamente dos fabricantes originais ou de um atacadista industrial especializado.

Finalmente, em terceiro lugar, o pedido de compra tem origem no próprio ciclo de suprimentos, reduzindo a incerteza operacional. Capacidade de determinar quando e onde os produtos serão comprados reduz a variância operacional.

Para Bowersox e Closs (2001), os ciclos constituem a melhor maneira de compreender e avaliar os processos logísticos. Por meio dos ciclos é possível identificar e analisar a dinâmica, as interfaces e as decisões que devem ser combinadas para a realização das 
operações de suprimentos, apoio à manufatura e distribuição física. Fornecem, portanto, a lógica de combinação dos elementos logísticos e constituem a base para implantação da logística integrada.

\subsection{Logística integrada}

Logística integrada é a administração dos fluxos e estoques como um processo, priorizando a eficiência da cadeia de suprimentos como um todo. Seu objetivo é integrar e coordenar as diversas atividades operacionais de modo que os fluxos entre as organizações ocorram continuamente e de forma sincronizada.

A sincronização das atividades logísticas e o estabelecimento de fluxos contínuos sem que haja interrupções ou falhas - pode eliminar a duplicação de esforços, diminuir a necessidade de estoque e proporcionar um melhor serviço aos clientes (BOWERSOX; CLOSS, 2001; CHANDRASHEKAR; SCHARY, 1999; LAMBERT; STOCK; ELLRAM, 1998; ASSUMPÇÃO, 2003, BALLOU, 2007). Desta forma, a gestão integrada da logística produz melhores resultados que funções gerenciadas individualmente, sem coordenação entre si (RUTNER; LANGLEY, 2000; CLOSS; SAVITSKIE, 2003).

A logística integrada requer o desenvolvimento de um esforço coordenado entre as empresas, seus fornecedores e compradores visando maior eficiência e competitividade. Exige, portanto, o estabelecimento de relacionamento cooperativo entre os agentes, além do contínuo investimento em tecnologias de informação (BOWERSOX; CLOSS; STANK, 1999).

Quanto ao estabelecimento de parcerias, os agentes devem combinar competências para cumprir a variedade e complexidade das tarefas que devem ser realizadas para satisfazer as necessidades logísticas. O comportamento cooperativo reduz riscos, elimina o trabalho duplicado e aprimora a eficiência do processo logístico (GAO; QI, 2007).

Quanto às tecnologias, os avanços da informática e a revolução nas telecomunicações possibilitaram a interligação dos processos de negócios além dos limites da empresa (FLEURY, 2000; LAMBERT; STOCK; ELLRAM, 1998). Por meio do disponibilização, acesso e transferência das informações, as empresas podem planejar de forma conjunta suas atividades e atuar como uma única organização.

Walker et al. (1998) descreve as etapas que as empresas devem cumprir para implantar a logística integrada: construção de infra-estrutura de comunicação, sistemas e processos entre as organizações parceiras; sincronização das informações captadas no ponto de venda e as 
decisões de oferta ao longo da cadeia, gestão global da logística de modo a garantir que o produto esteja continuamente em movimento e, finalmente, elaboração de medidas de desempenho.

\section{$\mathbf{X}-\mathbf{X}-\mathbf{X}$}

Não há dúvidas quanto ao importante papel da função logística nas empresas. Esta importância fica ainda mais evidente em um ambiente onde as empresas passam a ser vista como parte de uma ampla cadeia de atividades, cabendo ao processo logístico o estabelecimento das ligações entre elas.

Neste cenário, organizações dos mais variados setores vêm terceirizando suas operações logísticas para empresas especializadas denominadas prestadores de serviços logísticos. Estes agentes executam atividades logísticas para outras empresas (LEWIS; TALALAYEVSHY; 2000). Os próximos capítulos tratam do estudo destes importantes agentes, de como vem operando em rede e das tecnologias disponíveis para seu uso. 


\section{CAPÍTULO 4 \\ OPERADORES LOGÍSTICOS}

\subsection{Terceirização das atividades logísticas}

Atualmente, é possível observar um número crescente de empresas que vêm adotando como estratégia terceirizar suas operações logísticas para agentes especializados. Prestador de serviço logístico (PSL) é um agente que executa atividades logísticas para outras empresas (LEWIS; TALALAYEVSHY, 2000). Em 2003, as empresas norteamericanas gastaram $43 \%$ de seu orçamento destinado à área de logística com a terceirização. Das cem maiores empresas, $73 \%$ estão terceirizando suas atividades logísticas (FLEURY; RIBEIRO, 2001).

Fleury e Ribeiro (2001) apontam, ainda, outros fatos que evidenciam este fenômeno: forte crescimento na terceirização das atividades logísticas verificado na indústria química americana nos últimos anos e pesquisas apontando tendência à terceirização nos mercados europeus e americanos. Para fazer frente a este mercado, o crescimento médio de da receita operacional dos 56 maiores operadores foi de $18 \%$ ao ano entre 1996 e 1998.

No Brasil, apesar das poucas estatísticas disponíveis, é possível constatar intenso crescimento no setor de prestação de serviços logísticos. Entre 2000 e 2003, a receita total destes agentes pulou de $\mathrm{R} \$ 1,5$ bilhão para $\mathrm{R} \$ 6$ bilhões, um crescimento médio de $57 \%$ ao ano. E tudo indica que esta tendência prevalecerá. Pesquisa recente realizada junto a 93 empresas industriais brasileiras revelou $45 \%$ delas pretendiam aumentar suas despesas logísticas e que $81 \%$ delas se diziam satisfeitas com a terceirização (FLEURY; RIBEIRO, 2001).

O crescimento da procura por prestadores terceirizados é conseqüência das crescentes complexidade e importância estratégica da logística. Para um desempenho adequado da função logística são necessários elevados investimentos e habilidades específicas que podem ser melhor desenvolvidas por agentes especializados (FIGUEIREDO, 2005). As empresas contratantes do operador logístico são denominadas, na literatura, embarcadores.

As razões que levam as empresas a terceirizar suas atividades logísticas foram estudadas por diversos autores. Londe e Maltz (1992) apontaram: manutenção do foco na competência central; redução do investimento de capital em instalações, equipamentos e tecnologias; maior flexibilidade para se adequar às mudanças nos mercados e clientes; redução de custos; acesso a novos processos, idéias e tecnologia; aquisição de habilidade 
técnica; obtenção de escala em um dado canal de distribuição; aumento da produtividade e eficiência; e melhora no desempenho logístico.

Lieb e Bentz (2005) aponta três principais razões para a crescente terceirização: redução de custos decorrente da expertise e economias de escala dos operadores; melhora nos serviços oferecidos decorrente do foco e da eficiência dos operadores; e maior disponibilidade dos compradores para focar em suas próprias competências.

O’Brien (2002) acrescenta: ampliação da área de atuação, redução do ciclo de atendimento dos pedidos, aumento da flexibilidade, integração da cadeia de suprimentos e acesso à tecnologia de ponta.

Assim, importante pré-requisito para a terceirização das atividades logísticas é que os prestadores sejam capazes de oferecer vantagens em qualidade, flexibilidade, conhecimento e preço. Os operadores devem, portanto, ter habilidades e competências para permitir ganhos de economias de escala e escopo para seus clientes (FAWCETT; CLINTON, 1997).

\subsection{De operadores logísticos (3PLs) a integradores (4PLs)}

Há consenso entre os autores que o termo prestador de serviços logísticos é uma denominação genérica que se aplica a qualquer empresa que preste algum tipo de serviço logístico. Inclui, portanto, desde simples agentes de transporte até gestores de todo o processo logístico.

Entre um extremo e outro existem prestadores com níveis de sofisticação variados. Assim, é possível encontrar na literatura inúmeras denominações e classificações para estes agentes. Esta diversidade de denominações e de possibilidades de atuação tem dificultado uma categorização mais precisa destes agentes.

Fleury e Ribeiro (2001) destacam algumas delas: provedores de logística integrada (integrated logistics providers), empresas de logística contratada (contract logistics companies), operadores logísticos (logistics operators) e provedores de serviços logísticos terceirizados (third-party logistics providers - 3PLs).

$\mathrm{Na}$ literatura internacional vem predominando o termo $3 P L$ para definir prestadores de serviços logísticos que desenvolvem atividades com maior grau de sofisticação. Entretanto, não há consenso entre os autores sobre quais seriam as atribuições necessárias para que um prestador possa ser considerado $3 P L$.

Berglund (1999), por exemplo, define 3PL como um intermediário no canal logístico capaz de fornecer, por meio de contrato, todas ou um considerável número de atividades 
logísticas para outras empresas. Sink e Langley (1997) ressaltam a importância das atividades estarem integradas e coordenadas. Lundberg e Schönström apontam como características básicas a atuação como intermediário entre agentes da cadeia; alto nível de integração com o contratante e as funções desempenhadas e o estabelecimento de relacionamentos de longoprazo associado a um foco estratégico, onde as duas partes tratam-se como parceiros e seus objetivos convergem para uma relação ganha-ganha.

No Brasil, o termo operador logístico vem sendo utilizado como equivalente a 3PL. A Associação Brasileira de Movimentação e Logística (ABML) definiu estes agentes como sendo "o prestador de serviços logísticos especializado em gerenciar e executar todas as atividades de logística ou parte delas, nas várias fases da cadeia de abastecimento de seus clientes, agregando valor aos produtos, e com competência para no mínimo prestar, simultaneamente, serviços nas três atividades básicas da logística: controle de estoques, armazenagem e gestão de transportes".

Os operadores logísticos vêm sendo obrigados a se adequar - operacional e estrategicamente - a mercados e clientes cada vez mais exigentes e a processos logísticos cada vez mais sofisticados. Essas transformações podem ser percebidas na medida em que, nos últimos anos, muitas empresas deste segmento redefiniram ou diversificaram seus negócios, expandindo seus serviços e incorporando outras atividades (COATES; MCDERMOTT, 2002).

Assim, além de executar as atividades básicas da logística, muitos operadores passaram a atuar também em atividades relacionadas à informação e de valor adicionado como gestão da cadeia de suprimentos (BERGLUND; VAN LAARHOVEN; SHARMAN; WANDEL, 1999). Na gestão da cadeia de suprimentos, os operadores atuam como agentes intermediários, integrando e coordenando os fluxos e estoques entre as diferentes organizações. Estabelecem uma estrutura de rede eficiente, alinhando os processos operacionais de várias empresas, dentro de um sistema de cadeias de suprimentos integradas (LEWIS; TALALAYEVSKY, 2000).

Diversos autores (SKJOETT-LARSEN, 2004; NOVAES; DETONI, 2002; HERTZ; ALFREDSON, 2003) vêm chamando os operadores que atuam na gestão logística da cadeia de suprimentos de Fourth-Party Logistics (4PL). No Brasil vem sendo utilizado o termo integrador logístico.

A definição de integrador logístico é ainda mais controversa do que a de operador. Hertz e Alfredson (2003) definem integrador como sendo um prestador de serviço logístico capaz de absorver e coordenar integralmente as operações logísticas dos clientes. Persson e 
Virum (2001), como um prestador de serviço que atua nos níveis mais complexos e apresenta alta especificidade dos seus ativos. Sauvage (2002) ressalta o papel do integrador enquanto gestor dos fluxos entre os agentes da cadeia.

A definição de Bade e Mueller (1999) é a mais abrangente. Definem integradores logísticos ou 4PLs como intermediários que integram e gerenciam recursos, capacidades e tecnologias, próprias e de outros prestadores de serviços, para oferecer uma solução ampla para a cadeia de suprimentos, combinando capacidade de gestão e o uso da TI com as competências dos 3PLs. Assim, são capazes de planejar e executar uma ampla gama de serviços de forma integrada podendo, inclusive, oferecer uma solução logística completa.

Bade e Mueller (1999) ressaltam a importância do esforço tecnológico e da capacidade de inovar como arma estratégica importante para estes agentes. Os integradores vêm buscando aprimorar seus serviços e investindo pesadamente em TI para oferecer o que há de mais moderno em práticas e equipamentos de transporte, gerenciamento de estoques, serviços e aplicações de tecnologias para seus clientes.

Estudo realizado por Fleury e Ribeiro (2001) revelou que a grande parte dos prestadores de serviços logísticos que vem atuando nos níveis mais sofisticados, surgiu a partir de empresas que executavam atividades logísticas básicas. Por meio de aquisição, fusão, estabelecimento de parcerias ou mesmo crescimento orgânico, estas empresas vem adicionando novos serviços às suas atividades originais.

Assim, é possível encontrar no mercado, prestadores com diferentes níveis de sofisticação. Parte deles vem caminhando no sentido de adquirir conhecimento e capacidade para atuar como integradores, mesmo não oferecendo ainda uma solução completa. Neste trabalho, o termo operador logístico será adotado para todo e qualquer prestador de serviço que atue na gestão, mesmo que parcial, da logística integrada.

\subsection{Atividades do trabalho logístico}

Enquanto gestores do processo logístico na cadeia de suprimentos, os operadores podem atuar na logística de entrada, interna e de saída da cadeia de valor de Porter e Millar (1985) ou, seus equivalentes, os ciclos de suprimentos, de apoio à manufatura e de distribuição física descritos por Bowersox e Closs (2001).

O desempenho dos operadores depende da capacidade de gerenciar - operacional e estrategicamente - os processos logísticos. Os três ciclos de atividades devem estar sincronizados de modo que não ocorram interrupções ou desajustes. 
Os operadores estabelecem os elos entre os ciclos de distribuição, apoio à manufatura e de suprimentos dos agentes da cadeia. No ciclo de distribuição, atuam no fluxo de saída de materiais, peças e produtos acabados para entrega aos compradores. No apoio à manufatura, atuam na gestão dos estoques em processo na fabricação. E no ciclo de suprimentos, atuam no fluxo de entrada de materiais, peças e produtos acabados dos fornecedores para as fábricas, montadoras, depósitos ou varejistas.

O trabalho logístico é desenvolvido ao longo dos ciclos de distribuição, suprimentos e de apoio à manufatura. Cada uma das cinco áreas de trabalho descritas por Bowersox e Closs (2001) - projeto de rede; armazenagem, manuseio e embalagem; controle de estoque; transporte; e informação - envolve uma série de atividades.

A Associação Brasileira de Movimentação e Logística (ABML) descreveu as atividades básicas e complementares que os operadores logísticos podem desenvolver. Para cada atividade são detalhados os procedimentos envolvidos.

\subsubsection{Projeto de rede}

- Planejamento da rede de distribuição: definição e localização de plantas e armazéns (análise de localização)

- Dispor de instalações adequadas para a atividade de armazenagem

- Atendendo a legislação vigente e as regras das entidades legais (Corpo de Bombeiros, Vigilância sanitária, etc.);

- Atendendo as necessidades dos clientes em termos de docas de recebimento e expedição, equipamento de movimentação, estantes ou áreas adequadas, climatização quando necessário, etc.;

- Dispor de sistema de administração de armazéns adequado a cada caso, incluindo, quando necessário, sistemas de impressão e leitura de códigos de barra e de rádio freqüência;

\subsubsection{Armazenagem, manuseio e embalagem}

- Recebimento e conferência dos materiais e produtos pedidos

- Física: verificação da integridade, qualidade e validade dos materiais e produtos recebidos e das embalagens;

- Quantitativa: verificação das quantidades recebidas 
- Documental: verificação dos documentos tais como notas fiscais, manuais, certificados, etc.;

- Realização de controle de qualidade adequado na entrada dos bens e materiais armazenados;

- Separação

- Palletização para armazenagem e transferência: agrupamento de um ou mais produtos em pallets ou outro tipo de material permitindo o manuseio, armazenagem, movimentação e transporte por meio de empilhadeiras ou palleteiras e facilitando o transporte externo.

- Conteinerização: consolidação de produtos acabados ou semi-acabados em contêineres para movimentação e desembarque no exterior.

- Desconsolidação: processo de separação de cargas que chegam ao recebimento, consolidadas em um mesmo veiculo, com vários produtos de uma mesmo cliente ou de clientes diferentes.

- Seqüenciamento,

- Separação (pick/pack) dos produtos de acordo com os pedidos.

- Montagem de kits comerciais: agrupamento de itens diversos, formando um novo produto.

- Etiquetagem: identificação adequada dos materiais colocados em caixas (contendo diversas unidades de um ou mais produtos) e pallets, preferencialmente por meio do código de barras.

- Troca de etiquetas e manuais (nacionalização): substituição dos rótulos para nacionalização de produtos importados

- Capacidade de controlar e responsabilizar-se pelas avarias;

- Embalagem: aplicação do invólucro apropriado de acordo com o tipo de produto e/ou matéria prima movimentado para sua proteção e preservação.

- Armazenagem seca, refrigerada e alfandegada.

- Transferência de produto para centros de distribuição onde será armazenado e, mais tarde, distribuído. Os centros de distribuição podem pertencer ao fornecedor, prestador de serviços logísticos ou terceiros.

- Abastecimento de gôndolas: controle dos estoques no ponto de venda através da conferência das quantidades vendidas e do reabastecimento das gôndolas

- Separação e retirada dos pallets vazios para a liberação da área para futura utilização.

- Retirada de devoluções: recebimento e reenvio dos materiais e/ou produtos devolvidos pelo comprador (logística reversa) 
- Peças de reposição e serviços de suporte

- Cross docking: Os produtos são recebidos dos diversos fornecedores e rearranjados em novos lotes de acordo com os pedidos. A área de armazenagem é apenas de trânsito, e todos os produtos que entram devem sair no mesmo período.

\subsubsection{Estoque}

- Gerenciamento dos estoques, controlando as quantidades, localização e valores dos estoques físico dos clientes;

- Utilização de técnicas e meios modernos para acompanhar a evolução dos estoques no tempo, em termos de quantidades e localização e realizar previsões;

- Rastreamento:

- Rastreamento de pedidos: acompanhamento (follow up) dos pedidos junto aos fornecedores, incluindo situação atual e datas previstas para a entrega.

- Rastreamento de veículos: acompanhamento da posição dos veículos que transportam os materiais e produtos pedidos em tempo real (ou quase real) por meio de sistema de rastreamento via satélite ou rádio;

- Emissão de relatórios periódicos;

\subsubsection{Transporte}

- Embarque, remessa, consolidação e realocação de carga;

- Execução - ou contratação - e gerenciamento do transporte;

- Gerenciamento do transporte intermodal,

- Qualificação e seleção de transportadoras;

- Negociação do serviço desejado junto às transportadoras;

- Coordenação das viagens das transportadoras;

- Realização de pesquisa periódica do valor dos fretes nas praças desejadas;

- Negociação e realização do pagamento dos fretes;

- Mensuração e controle do desempenho das transportadoras frente aos padrões estabelecidos;

- Emissão de relatórios de acompanhamento do nível de serviço.

- Programação das entregas por meio de softwares (roteirização) 
- Milk run é um sistema de coleta programada onde é definida a melhor rota para o veículo e a quantidade que deve ser coletada em cada fornecedor de modo a aproveitar melhor a capacidade do veículo de transporte.

- Porta a porta: transporte de porta a porta, desde o fornecedor até o cliente final.

\subsubsection{Informação}

- Gestão de informações logísticas: obtenção e processamento das informações necessárias para o desenvolvimento dos serviços logísticos prestados. Entre elas: demanda prevista e real, negociação e ordem de fornecimento, dados técnicos e garantias, programas de produção, programação de coleta de transportadoras, documentos fiscais, etc.

- Gestão do relacionamento com os clientes: capacidade de administrar as informações de clientes de uma forma organizada e eficaz

- Assessoria fiscal: orientação aos clientes, adequando as rotinas à legislação vigente para legalização das operações e redução dos custos finais.

- Estudos de Viabilidade: estudos visando desenvolvimento de processos e redução dos custos.

- Realização de projeções: cálculo das necessidades futuras, orientando o posicionamento dos estoques.

- Emissão de relatórios estatísticos e gerenciais

- Consultoria

- Prestação de contas

- Medida do desempenho: demonstrativo dos encargos financeiros relacionando todas as atividades que geraram gastos com as respectivas autorizações, quando for o caso e apresentando as medidas de desempenho.

Se o operador logístico tiver atuação internacional deverá, ainda, estar apto a executar as seguintes atividades:

- Atuação dentro da legislação do país de origem e destino,

- Prestação de serviços de importação e exportação,

- Documentação e desembaraço aduaneiro,

- Realização de operações portuárias e frete internacional,

- Operação de armazéns alfandegados e

- Prestação de assessoria e consultoria em comércio exterior. 
As atividades logísticas podem ser combinadas de diversas maneiras. As diferentes combinações resultam num dado custo e num determinado nível de serviço ao cliente. A redução nos custos decorre de uma gestão mais eficiente dos fluxos e armazenagem dos produtos. A elevação da receita, do desenvolvimento de operações logísticas diferenciadas, com maior valor agregado, aumentando a lealdade e satisfação dos clientes (BOWERSOX; CLOSS; STANK, 1999).

Os operadores definem as atividades que serão realizadas e como serão executadas a partir do seu posicionamento estratégico. Berglund (1997) aponta os elementos relevantes na avaliação do posicionamento estratégico dos operadores logísticos. O autor analisa os operadores a partir de duas perspectivas: interna e do mercado atendido.

Na perspectiva do mercado atendido, os operadores são vistos a partir de seus clientes. As variáveis importantes são: escopo geográfico, indústrias e segmentos da cadeia de suprimentos onde atuam, atividades e serviços desenvolvidos e diferenciação (desempenho versus custo, serviços oferecidos, qualidade dos serviços, etc.).

$\mathrm{Na}$ perspectiva interna, os operadores são vistos a partir de seu próprio processo de produção. Neste caso, as variáveis relevantes são: atividades e serviços desenvolvidos, integração vertical, capacidade de desenvolvimento de soluções para os clientes.

\subsection{Competitividade dos operadores logísticos}

O operador logístico é competitivo quando é capaz de criar valor para seus clientes. Berglund (1997) identifica as questões chave para a competitividade destes agentes.

- Ter elevada eficiência operacional e fornecer a melhor relação custo-serviço. Exige capacidade física, equipamentos adequados e habilidade operacional.

- Partilhar recursos, tais como meios de transporte, depósitos, consolidação de carga, etc., visando diminuir custos. Pode ser feito a partir da integração com clientes, entre diferentes clientes ou mesmo com parceiros, gerando economias de escala.

- Buscar a integração horizontal e vertical: diante da variedade e complexidade de tarefas que devem ser realizadas para satisfazer as necessidades logísticas, é natural que os operadores terceirizem parte de suas atividades e/ou estabeleçam parcerias com prestadores de serviços ou mesmo com outros operadores logísticos.

- Integração vertical é o desenvolvimento da estrutura de serviços do operador. O operador pode focar nos serviços onde é competitivo e comprar de terceiros quando os custos são inferiores ou o desempenho é superior. 
- Integração horizontal é o estabelecimento de parcerias com empresas similares, possibilitando ampliar o escopo geográfico.

- Desenvolver operações dos clientes. Para planejar e analisar os sistemas logísticos dos clientes é necessário alto nível de habilidade em logística. O objetivo é criar valor por meio do desenvolvimento da organização do cliente, administrando partes de sua cadeia de suprimentos.

Berglund (1997) ressalta a integração e a coordenação das atividades logísticas como elementos centrais na competitividade dos operadores e, como consequiência, o estabelecimento de cooperação com outros prestadores de serviços. Integração e coordenação exigem forte relação de confiança, metas comuns e compatibilidade técnica entre os agentes que só são conseguidas por meio de parcerias.

O estabelecimento de parcerias, entretanto, não deve estar restrito a outros prestadores de serviço logísticos. Também são importantes os demais agentes da cadeia de suprimentos: clientes, fornecedores e distribuidores (CHOPRA; MEINDL, 2001).

Integração, coordenação e o estabelecimento de parcerias exigem que os operadores sejam capazes de partilhar dados e outras informações e de construir canais eficientes de comunicação com seus parceiros (BOWERSOX; CLOSS, 2001; ASSUMPÇÃO, 2003; TURBAN; RAINER; POTTER, 2003). A TI tem, portanto, papel central no desempenho destes agentes.

As tecnologias permitem a gestão integrada dos canais que coletam, transmitem e processam as informações e os canais físicos, como agentes, transportadoras, centros de distribuição, plantas industriais, etc. (LEWIS; TALALAYEVSKY, 2000). A sincronização das atividades logísticas entre as várias empresas possibilita redução nos estoques, maior agilidade no atendimento aos clientes e a capacidade de oferecer produtos customizados (WANKE, 2003).

Assim, o desempenho dos operadores logísticos depende da capacidade de gerenciamento operacional e estratégico dos processos, da gestão da informação e do conhecimento em todas as fases dos ciclos logísticos e, consequentemente, da utilização intensiva da TI (LANGLEY; ALLEN; TYNDALL, 2002).

É por meio da TI que os operadores são capazes de partilhar dados e outras informações e coordenar suas atividades com as de seus parceiros para diminuir seus custos e aprimorar seu serviço (BOWERSOX; CLOSS, 2001; ASSUMPÇÃO, 2003; TURBAN; RAINER; POTTER, 2003). 


\subsection{Excelência logística}

Os operadores devem ter como meta estratégica atingir a excelência logística. Excelência logística é operar com o menor custo logístico total para um dado nível de serviço (BOWERSOX; CLOSS, 2001). Para os autores, a excelência logística pode ser alcançada por meio dos seguintes objetivos operacionais:

- Resposta rápida: atender aos clientes individualmente e de forma rápida.

- Variância mínima: minimizar os efeitos de eventos que perturbem o funcionamento do sistema. Por exemplo, atrasos ou erros na entrega dos produtos, no recebimento de pedidos, etc.

- Estoque mínimo: operar com o menor nível possível de estoque para atender os objetivos operacionais. Envolve comprometimento de ativos e velocidade de rotação dos estoques. Se a rapidez na entrega do produto é importante, deve utilizar meios de transporte mais rápidos. Se utilizar meios de transporte mais baratos e, portanto, mais lentos e menos confiáveis, deve manter maiores estoques para enfrentar as incertezas.

- Consolidação da movimentação: ser capaz de operar com todas as variáveis envolvidas na movimentação de mercadorias e realizá-la do modo mais eficiente possível. O custo do transporte está relacionado ao tipo de produto, tamanho e distância percorrida e é um dos custos logísticos mais significativos.

- Flexibilidade: ser capaz de se adequar a diferentes parceiros com objetivos estratégicos e estruturas organizacionais variadas.

- Qualidade: buscar o aperfeiçoamento contínuo para evitar erros ou avarias no transporte e armazenagem, diminuindo os custos logísticos.

- Diferenciação: oferecer serviços diferenciados aos clientes, facilitando o processo de agregação de valor.

- Apoio ao ciclo de vida: garantir o desempenho dos produtos num determinado intervalo de tempo. Inclui capacidade para retirar produtos ou partes dos produtos de circulação para reciclagem.

\section{$\mathbf{X}-\mathbf{X}-\mathbf{X}$}

A excelência operacional em logística exige integração e coordenação das várias atividades logísticas, estabelecimento de parcerias com outros agentes da rede - clientes, 
fornecedores, outros operadores e prestadores de serviço - e, consequentemente, a utilização intensiva das tecnologias de informação.

A definição das necessidades de informação das empresas e como serão atendidas pela tecnologia não é uma tarefa simples. Sobretudo quando tanto as condições dos negócios como as tecnologias estão se alterando tão rapidamente. Com a crescente complexidade e rapidez na evolução da TI, são importantes estudos que ajudem a identificar e analisar as tecnologias disponíveis, como utilizá-las e ser capaz de integrá-las a outras funções. O próximo capítulo abordará este tema. 


\section{CAPÍTULO 5 \\ TECNOLOGIA DA INFORMAÇÃO}

\subsection{Evolução da Tecnologia da Informação}

O conceito de TI engloba as várias tecnologias que coletam, processam, armazenam e transmitem informações. "Assim envolve, além de computadores, equipamentos de reconhecimento de dados, tecnologias de comunicação, automação de fábricas e outras modalidades de hardware e de serviços" (PORTER, 1999, p. 83).

A evolução da TI permitiu que fosse assumindo, cada vez mais, um papel estratégico nas empresas. No início, melhorou os componentes físicos das atividades e facilitou o processamento de informação. Mais tarde, permitiu a integração e coordenação dos processos internos das empresas, tais como vendas, produção e gestão de materiais. Finalmente, possibilitou a integração e coordenação dos processos da empresa com os de outras organizações, possibilitando o estabelecimento das redes (APPLEGATE; AUSTIN; MCFARLAN, 2003).

Applegate, Austin e McFarlan (2003) identificam quatro fases na evolução da tecnologia da informação:

- $1^{\circ}$ fase: 1950 a 1970

Imperaram os mainframes, grandes computadores com memória e capacidade de processamento elevadas. Os mainframes provocaram mudanças profundas no processamento das informações nas organizações, substituindo o trabalho manual e permitindo melhorias operacionais significativas. Entretanto, seu custo elevado, a necessidade de condições especiais para instalação e a exigência de equipe técnica para o desenvolvimento, manutenção e operação, dificultavam a adoção desta tecnologia. As empresas pioneiras na sua utilização eram intensivas em informação como bancos, seguradoras, etc.

- $2^{\circ}$ fase: final dos anos 70

Surgiram os microcomputadores. Menores e incomparavelmente mais baratos que os mainframes, tornaram-se populares rapidamente. Ao mesmo tempo, os aplicativos (softwares) foram se tornando mais amigáveis, podendo ser operados mesmo por usuários sem conhecimento técnico. Os usuários passaram a controlar parcelas crescentes do processamento e gestão da informação e as organizações reconheceram a importância da TI na execução de tarefas e na tomada de decisão. 
- $3^{\circ}$ fase: a partir dos anos 80

Como resultado dos avanços das telecomunicações e da computação, foram desenvolvidos os Sistemas de Informação Interorganizacionais (Information Organization Systems - IOS). Estes sistemas distribuíam as informações utilizando redes de telecomunicação. As redes eram privadas, construídas por grandes empresas, instituições, empresas de telefonia fixa, etc. e conectavam diferentes organizações previamente acordadas. $\mathrm{O}$ acesso era caro e com inúmeras dificuldades técnicas.

- $4^{\circ}$ fase: a partir dos anos 90

Começa a se difundir a Internet. A Internet é um conjunto de inúmeras redes de computadores, conectadas entre si, que permite a comunicação e distribuição de informações, programas e equipamentos entre empresas e instituições. É composta de redes comerciais e públicas de mais de duzentos países em todo o mundo (LAUDON; LAUDON, 2004). Atualmente, a infra-estrutura de TI é planejada para permitir o fluxo de informação dentro da empresa e com seus parceiros externos por meio da internet, configurando redes de empresa.

A TI ocupa diferentes papéis no estabelecimento das redes. Narasimhan (2001) aponta três deles:

- Infra-estrutura de apoio: base para as aplicações de TI;

- Gestão da criação de valor: integração das funções internas;

- Operações logísticas: integração com parceiros externos.

Enquanto infra-estrutura de apoio, a TI constitui a plataforma tecnológica que dá suporte aos sistemas de empresa e é composta de hardware, software, tecnologia de armazenagem, redes de telecomunicações e recursos humanos (LAUDON; LAUDON, 2004).

Enquanto instrumento para integração, devem ser destacados os aplicativos denominados sistemas de empresa - que possibilitam a integração interna das empresas como, também, com seus parceiros externos (LAUDON; LAUDON, 2004).

A seguir serão discutidos o papel da TI enquanto infra-estrutura e identificados e analisados os aplicativos disponíveis no mercado e suas aplicações na logística.

\subsection{Tecnologia e Sistemas de informação}

O termo TI é, com frequiência, utilizado no sentido de Sistemas de Informação (SI). O conceito de TI refere-se aos diversos componentes como hardware, bancos de dados, softwares e outros que, organizados, formam os sistemas de informação. Sistema de 
Informação é, portanto, uma coleção de componentes de TI organizados com um propósito específico (LEWIS; TALALAYEVSKY, 2000).

Os Sistemas de Informação coletam dados extraídos de eventos reais que ocorrem nas organizações e no seu ambiente físico, realizam seu processamento transformando-os em informação e, finalmente, transferem a informação processada para as pessoas ou atividades onde serão utilizadas. Informação são os dados organizados e disponibilizados de modo a permitir seu entendimento e utilização (LAUDON; LAUDON, 2004).

Turban, Rainer e Potter (2003) afirmam que SI eficientes devem:

- Processar as transações de forma rápida e precisa. Transação são todos os eventos ocorridos na empresa como a venda de mercadorias, emissão de cheques, depósitos bancários, etc. Cada transação gera dados que devem ser coletados e processados.

- Armazenar os dados num formato que permita atualização e acesso rápido.

- Estabelecer o acesso e a transferência rápida de dados e informação utilizando redes de comunicação.

- Selecionar e organizar as informações relevantes.

- Integrar interna e externamente as organizações. A integração interna facilita a tomada de decisão. A externa reduz o tempo de entrega do produto, diminui a necessidade de estoque e eleva a satisfação dos clientes.

- Dar suporte à tomada de decisão e a coordenação das organizações.

- Aumentar a competitividade. Como, por exemplo, os sistemas de reservas implantados por empresas aéreas nos anos 70 e os atuais sistemas de apoio à cadeia logística.

A construção de SI eficientes exige que se conheça a empresa, suas necessidades de informação, o ambiente onde está inserida e os problemas que devem ser solucionados. É, ainda, importante levar em conta aspectos culturais das empresas e das pessoas envolvidas (LAUDON; LAUDON, 2004).

Um outro conceito importante é o da eficácia da TI ou dos SI. De acordo com Laurindo (2002), a eficácia dos SI está relacionada com os resultados que proporciona para a organização em que é utilizado. Diz respeito aos impactos que este SI tem nos objetivos que nortearam seu desenvolvimento e implantação, bem como nas operações e estratégia da empresa. Quando se discute o alinhamento estratégico da SI com o negócio, o que precisa ser considerado (e avaliado) é o uso eficaz deste SI.

A seguir serão descritos os principais componentes dos SI, suas relações e hierarquias. 


\subsection{Arquitetura da informação}

Turban, Lee, King e Chung (2002) definem arquitetura da informação como um mapa das necessidades de informação da empresa e a forma como estão sendo atendidas pela TI. Para Laudon e Laudon (2004) é a forma como as empresas utilizam a TI para atingir seus objetivos. Para eles, a arquitetura de informação permite avaliar se a TI está atendendo as necessidades de informação das empresas.

A arquitetura de informação abrange vários aplicativos. A plataforma tecnológica para estes aplicativos é denominada infra-estrutura de TI. A figura 11 ilustra os principais componentes da infra-estrutura de TI e da arquitetura de informação em uma empresa, indicando suas relações e hierarquias (LAUDON; LAUDON, 2004).

Estão ilustrados:

- A infra-estrutura de TI que fornece suporte tecnológico aos aplicativos. É composta de hardware, software, tecnologia de armazenamento e bancos de dados, redes e recursos humanos para operar os equipamentos. De modo geral, a infra-estrutura está ligada à infra-estrutura pública, tais como a internet.

- Os aplicativos que devem atender as necessidades operacionais e estratégicas da empresa. Entre os aplicativos estão:

- Os sistemas de informação que atendem os quatro níveis das organizações operacional, de conhecimento, gerencial e estratégico.

- Os sistemas de informação que automatizam as áreas funcionais - vendas e marketing, produção, finanças, contabilidade e recursos humanos. Estes sistemas são os primeiros a ser implantados na maioria das organizações.

- Finalmente, os principais sistemas de informação gerenciais que dão suporte aos processos globais da empresa, abrangendo todas as unidades organizacionais e conectando a empresa aos seus clientes e fornecedores. São eles: sistemas de empresas (ERP), sistemas de gestão da cadeia de suprimentos (SCM), sistemas de gestão de relacionamento com os clientes (CRM) e sistemas de gestão do conhecimento (KMS). 
Figura 11 - Arquitetura da Informação da empresa e infra-estrutura de TI

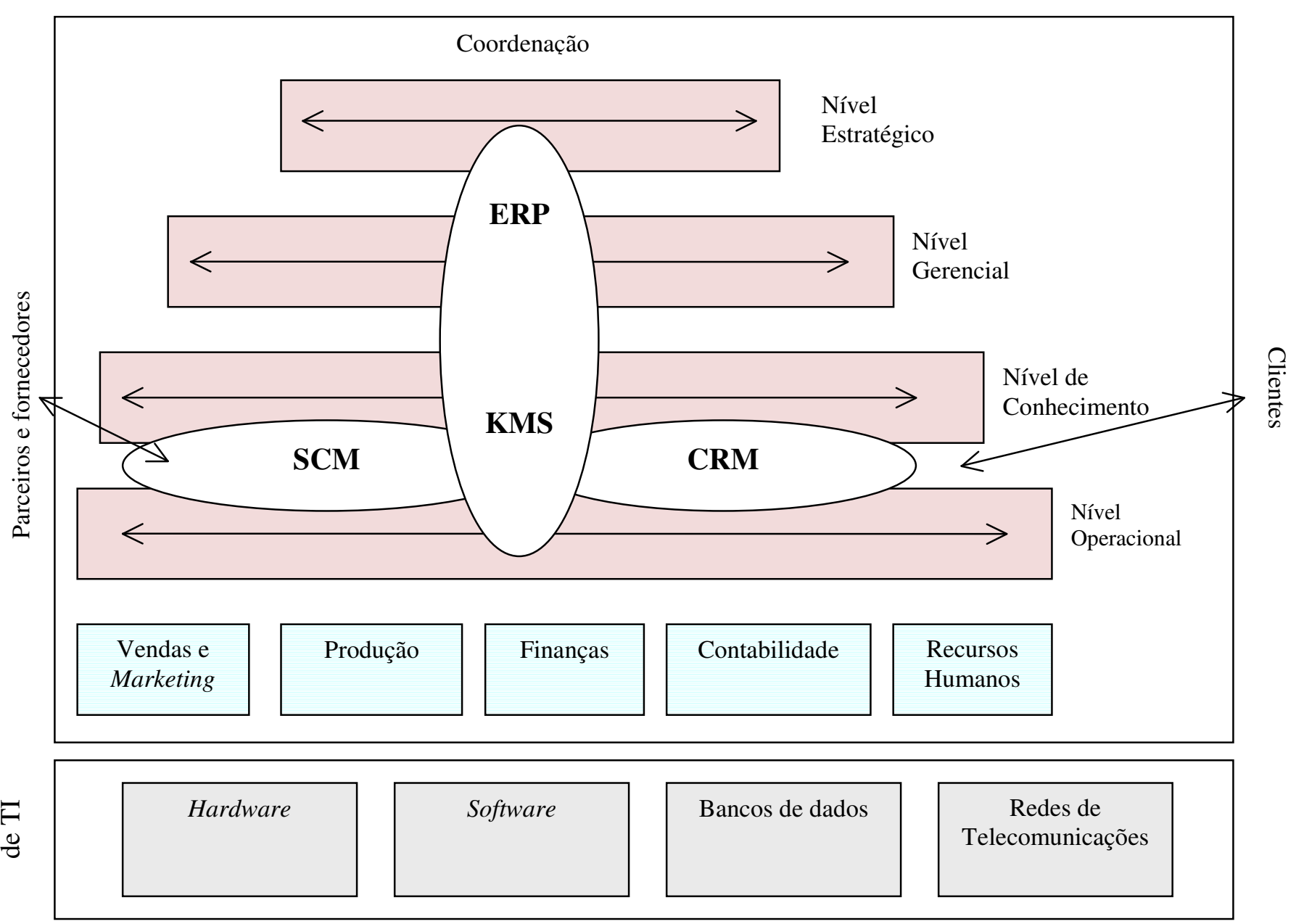

Fonte: Laudon e Laudon (2004, p. 27).

Serão descritos, a seguir, os quatro componentes da infra-estrutura: hardware, software, bancos de dados e redes de telecomunicação. Em seguida, os aplicativos da arquitetura de informação: sistemas de informação horizontais e gerenciais.

Os sistemas de informação verticais não serão abordados por estarem voltados para o atendimento de funções específicas e que não atendem aos objetivos da tese. Já os sistemas de informação horizontais serão analisados porque revelam a complexidade dos sistemas internos e são importantes para o entendimento dos aplicativos de empresa. Estes aplicativos foram desenvolvidos com o objetivo de integrar e coordenar todas as funções e níveis da organização em um único sistema. Estão, portanto, em grande parte, baseados nos sistemas horizontais. 


\subsubsection{Infra-estrutura de TI}

Infra-estrutura de TI é a plataforma tecnológica que dá suporte aos sistemas de empresa. É composta de hardware, software, tecnologia de armazenagem, redes de telecomunicações e recursos humanos (LAUDON; LAUDON, 2004).

\subsubsection{Hardware}

Hardwares são os equipamentos físicos utilizados para entrada, processamento e saída de dados em um sistema de informação. Inclui diversas tecnologias tais como teclados, scanners ópticos, dispositivos para transação a vista, monitores, impressoras, saída de voz, etc.; e são controlados e coordenados por meio de softwares (LAUDON; LAUDON, 2004).

A todo o momento surgem novas tecnologias. As empresas devem estar em constante atualização, buscando novas opções. Mas, integrar novos hardwares aos sistemas já existentes não é uma tarefa simples. Isto porquê (LAUDON; LAUDON, 2004):

- Em muitas empresas a infra-estrutura de TI é fragmentada e incompatível, dificultando a conectividade e, portanto, o fluxo da informação.

- Quando uma empresa altera sua infra-estrutura é necessário recriar grande parte dos softwares para que possam ser executados no novo sistema operacional do hardware.

- Finalmente, pode ser preciso inserir novamente os dados em outro formato e treinar os empregados para operar a nova tecnologia.

\subsubsection{Softwares}

Softwares ou programas dão instruções para que o computador execute suas tarefas. Operam controlando e coordenando os componentes de hardware. Podem ser classificados em dois tipos principais: softwares de sistema e softwares aplicativos (LAUDON; LAUDON, 2004):

- Os softwares de sistema fornecem instruções para funções internas básicas dos sistemas do computador. Controlam e dão suporte ao sistema do computador e ao processamento de informações executando tarefas como, por exemplo, o carregamento automático das aplicações durante o processamento secundário. Os softwares de sistema fornecem os recursos e impõem limites para os softwares aplicativos. 
- Os softwares aplicativos fornecem instruções para a execução das atividades de processamento das informações. Estas atividades podem ser amplas - como processamento de textos - ou mais restritas - como programas que executam folhas de pagamento. Os softwares aplicativos podem ser proprietários ou de prateleira.

- Softwares proprietários atendem uma necessidade empresarial particular ou única. Podem ser desenvolvidos internamente, pela área de Sistemas de Informação da empresa, ou contratado junto a fornecedores de softwares (denominados softwares contratados).

- Softwares de prateleira são comprados, arrendados ou alugados de fornecedores. Podem ser padrão ou personalizáveis podendo, neste caso, adaptarem-se às necessidades da empresa.

O desenvolvimento de softwares é lento, complexo e sujeito a erros. As grandes aplicações contêm milhões de linhas de códigos de computador, com inúmeros autores e desenvolvimento demorado. Quanto mais complexo, maior a probabilidade de se verificarem erros e mais elevados são os seus preços (IVERSENA; NGWENYAMAB, 2006).

\subsubsection{Tecnologia de armazenagem de dados}

Para serem competitivas, as empresas devem ser capazes de obter, organizar e interpretar dados. Assim, o gerenciamento dos dados é central na execução das funções empresariais (LAUDON; LAUDON, 2004; TURBAN; RAINER; POTTER, 2003).

Até 1970, as organizações gerenciaram seus dados em um ambiente de arquivos (abordagem tradicional). Arquivo de dados é um conjunto de registros relacionados logicamente. Neste ambiente, cada aplicação possui um conjunto de dados com todos os registros que necessita. Isto porque as aplicações foram sendo desenvolvidas gradativamente, e cada uma delas estava associada ao seu próprio arquivo de dados (TURBAN; RAINER; POTTER, 2003).

$\mathrm{O}$ armazenamento dos dados em um ambiente de arquivos gera alguns problemas (TURBAN; RAINER; POTTER, 2003):

- As funções comuns das diferentes aplicações corporativas são elaboradas, codificadas, documentadas e testadas individualmente.

- O mesmo dado pode estar inserido em vários arquivos, o que aumenta a possibilidade da ocorrerem inconsistências. 
- Os arquivos de dados podem ser organizados ou armazenados de diferentes maneiras dificultando o acesso de outras aplicações.

- Novas aplicações podem ser adicionadas a qualquer momento comprometendo a segurança do ambiente.

O resultado final eram centenas de aplicações e arquivos de dados nas empresas sem que houvesse conhecimento sobre seus conteúdos. Estes problemas levaram ao desenvolvimento das tecnologias de bancos de dados.

Em um ambiente de banco de dados todos os dados estão armazenados em um único repositório onde podem ser atualizados, recuperados e acessados por diversos aplicativos. Esta abordagem reduz significativamente a redundância, o isolamento e a inconsistência de dados, além de permitir maior segurança e integridade.

O acesso aos dados é feito por meio de um grupo de softwares denominado Sistema de Gerenciamento de Banco de Dados (Database Management Systems - DBMS). Os DBMSs podem ser carregados nos computadores dos usuários e utilizados a qualquer momento e em qualquer local, ou em computadores interconectados por meio de redes locais (LAUDON; LAUDON, 2004)

\subsubsection{Redes de comunicação}

As redes de comunicação conectam dois ou mais computadores, assim como impressoras e outros dispositivos, permitindo: o compartilhamento de hardware, softwares, bancos de dados; além de documentos, informações e idéias; a transmissão eletrônica de dados, informações e documentos; a ligação entre as empresas e entre empresas e seus clientes e o desenvolvimento de trabalho em equipe (TURBAN; LEE; KING; CHUNG, 2002).

Segundo Turban, Lee, King e Chung (2002), as redes podem ser classificadas em redes locais (Local Área Network - LAN) ou redes amplas (Wide Área Network - WAN).

- Redes locais $(L A N)$ conectam computadores numa área física delimitada, como um prédio ou uma fábrica. Permitem que os usuários compartilhem recursos corporativos e integrem diversas funções num único sistema. Os usuários podem acessar bancos de dados comuns e compartilhar impressoras e outros equipamentos. As redes locais podem estar conectadas a outras redes.

- Redes amplas (WAN) cobrem grandes extensões. Permitem enviar e receber dados além dos limites das redes locais. As WANs podem ser comerciais - pertencentes às 
concessionárias de comunicação como empresas de telefonia, TV a cabo, etc. - ou privadas - de propriedade de grandes empresas. Entre estas redes estão as Redes de Valor Agregado (Vallue Added Network - VAN) e as Redes Privadas Virtuais (Virtual Private Network - VPN).

- Redes de Valor Agregado (VANs) são redes privadas, utilizadas pelas organizações exclusivamente para tráfego de dados. Podem oferecer, ainda, serviço de armazenagem, rastreamento e retransmissão de mensagens de teleconferência.

- Redes Privadas Virtuais (VPNs) são redes operadas por concessionárias de comunicação. Conectam as redes locais das empresas à Internet ligando usuários remotos, filiais e parceiros de todo o mundo. As VPNs são redes seguras onde os dados trafegam criptografados e são bastante utilizadas pelas empresas internacionais como substitutas das VANs de longa distância.

As redes começaram a ser desenvolvidas nos anos 60, quando Departamento de Defesa dos Estados Unidos estabeleceu uma rede experimental - a ARPANET. A ARPANET interligava alguns centros militares e de pesquisa e tinha como objetivo permitir o compartilhamento dos recursos computacionais e a troca de informação através de uma rede flexível, ampla e tolerante a falhas (TURBAN; REINER; POTTER, 2003).

Nos primeiros anos, o acesso a ARPANET era restrito aos militares e pesquisadores na área de defesa. Nos anos 80, foram sendo incorporados outros centros de pesquisa e, também, universidades. Isto foi possível graças a adoção de padrões abertos que permitiram a conexão entre diferentes computadores, independente do porte, dos sistemas operacionais ou aplicativos utilizados. O conjunto das diversas redes veio a ser denominado internet (TURBAN; REINER; POTTER, 2003).

\subsection{Internet}

A internet é o conjunto de inúmeras redes de computadores. Entre elas estão redes amplas com alcance internacional (backbones) mantidas, geralmente, pelos governos, uma variedade de sub-redes comerciais (provedores de serviço Internet, redes de telefonia fixa, redes de TV a cabo, etc.) e inúmeras redes privadas e institucionais. A figura abaixo ilustra a arquitetura da rede internet (TURBAN; LEE; KING; CHUNG, 2002). 
Figura 12 - Arquitetura Internet

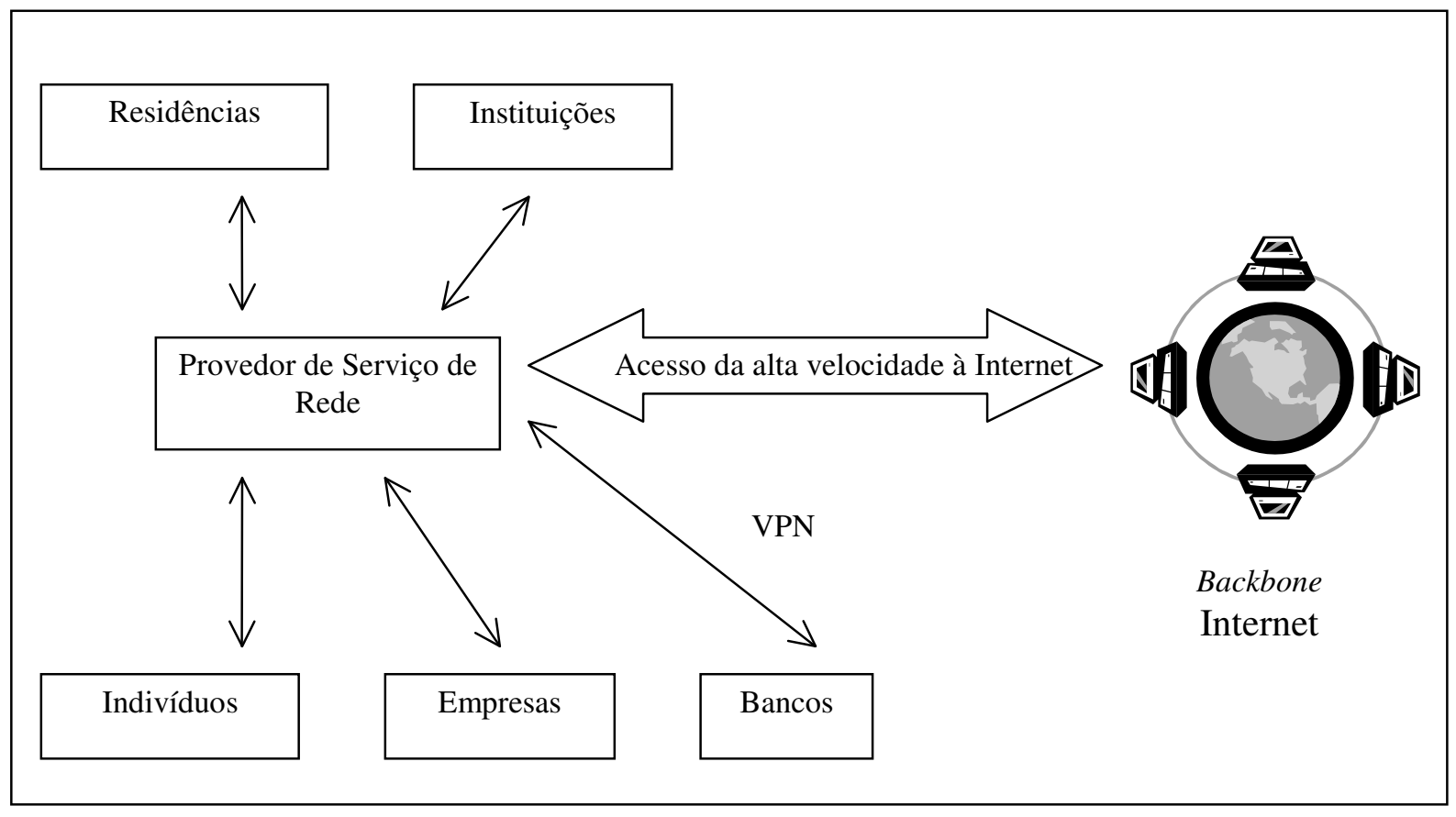

Fonte: adaptado de Turban, Lee, King e Chung (2002).

Atualmente grande parte da rede física é de propriedade dos provedores de serviços de rede. Os provedores podem manter grandes redes ou, então, pequenas redes conectadas às grandes redes. Os de grandes redes são denominados provedores de backbone. Os das pequenas redes são denominados provedores de acesso. Empresas e pessoas físicas se conectam a Internet através destes provedores (TURBAN; LEE; KING; CHUNG, 2002).

Os provedores de backbone devem estar ligados entre si. As diversas redes backbone transmitem informações de forma recíproca. Isto significa que cada provedor transporta o tráfego dos outros provedores de backbone sem que haja cobrança pelo serviço. Portanto, não é levado em conta o volume utilizado, tempo e distância. A tendência é que esta prática se altere devido as exigências cada vez maior de largura de banda e a necessidade de investimentos em ampliação (TURBAN; LEE; KING; CHUNG, 2002).

Antes da disseminação da Internet, as empresas utilizavam as redes privadas administradas por terceiros. Estas redes ofereciam segurança e elevada capacidade, mas o acesso era caro e com inúmeras dificuldades técnicas. Sua utilização, portanto, estava restrita às grandes empresas (APPLEGATE; AUSTIN; MCFARLAN, 2003).

A Internet permitiu que as redes invadissem as organizações na medida em que simplificou e barateou significativamente os custos de utilização. Sua tecnologia é de fácil 
utilização e independe dos computadores ou plataformas de TI que a organização esteja utilizando (APPLEGATE; AUSTIN; MCFARLAN, 2003).

Segundo Turban, Lee, King e Chung, (2002), muitas empresas que já utilizavam redes internas para gerenciar e coordenar seus processos de negócios passaram a utilizar a tecnologia Internet. Redes corporativas internas que utilizam a tecnologia Internet são denominadas intranet. Intranets ampliadas, incorporando usuários autorizados fora da organização, são denominadas extranets. Extranets são utilizadas para coordenar as atividades da empresa com seus parceiros externos. A seguir serão discutidas estes duas tecnologias.

\subsection{Intranet}

Intranet é uma rede corporativa local $(L A N)$ que utiliza a tecnologia Internet. Conecta diversos computadores, bancos de dados e aplicativos e é utilizada para comunicação e colaboração entre empregados de uma mesma empresa (TURBAN; LEE; KING; CHUNG; 2002).

Sua arquitetura de rede utiliza os conceitos e ferramentas Web possibilitando fácil navegação, oferecendo mecanismos de busca e ferramentas para comunicação e colaboração. Opera utilizando uma rede privada protegida por firewalls que impedem o acesso de usuários não autorizados.

Para construir uma Intranet a empresa precisa: servidor $W e b$, navegadores, ferramentas para publicação na Web, bancos de dados back-end, redes TCP/IP (LAN ou WAN) e firewalls. A figura abaixo retrata a arquitetura da Intranet. 
Figura 13 - Arquitetura da intranet

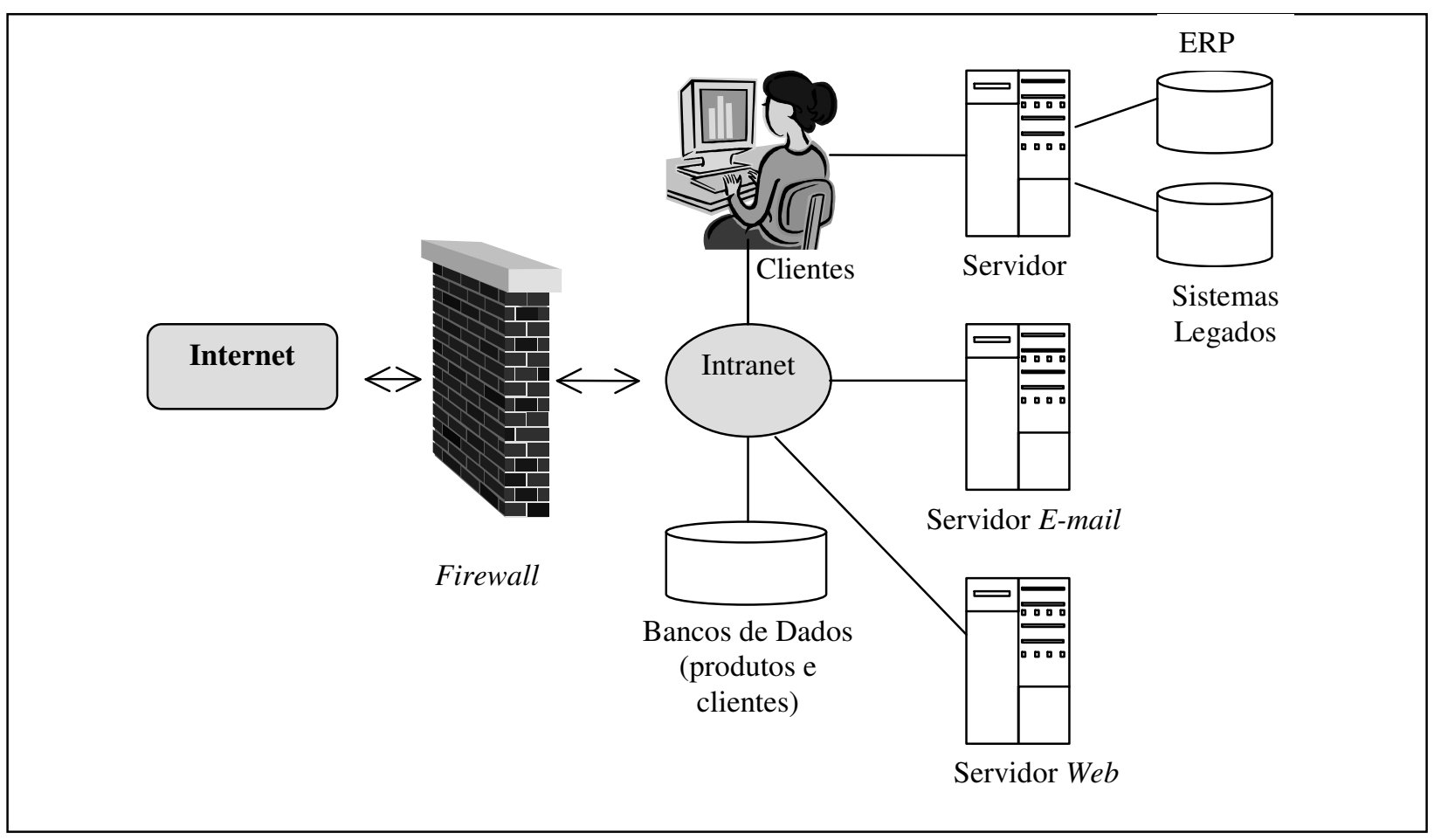

Fonte: adaptado de Turban, Lee, King e Chung (2002, p. 441).

Turban, Lee, King e Chung (2002) descrevem as diversas funcionalidades da intranet para as empresas:

- Bancos de dados apoiado na Web

- Mecanismos de busca, ferramentas de indexação e catálogos que localizam através de palavra chave.

- Comunicação interativa como Chat, suporte de áudio, vídeo-conferência.

- Distribuição de documentos, incluindo captura e rastreamento.

- Ferramentas de apoio a grupos como e-mail, grupos e listas de discussão, etc.

- Apoio a sistema de telefonia baseados em computador.

Descrevem, ainda, as várias aplicações e benefícios que as empresas podem auferir com a utilização da Intranet:

- Acesso á informações sobre produtos, políticas e procedimentos corporativos, pedidos de compra, telefones corporativos, recursos humanos, programas de treinamento, banco de dados dos clientes, arquivos de imagens, etc.

- Serviço ao cliente oferecendo informações sobre envio e disponibilidade dos produtos 
- Busca e acesso a documentos, aumentado a produtividade e facilitando o trabalho em equipe

- Informação personalizada através das páginas Web ou e-mail

- Partilha de conhecimento

- Facilidade para decisão em grupo e processos de negócio

- Acesso à informação e aos especialistas para tomada de decisão.

- Eliminação das barreiras de incompatibilidade entre as tecnologias devido a adoção da tecnologia Web pelos parceiros de negócio..

- Distribuição de softwares

- Acesso a figuras, fotos, mapas e outros documentos independente de onde estejam armazenados e do local onde o empregado esteja.

- Condução e gestão de projetos através da Intranet

- Treinamento

- Processamento de transação: dados podem ser introduzidos uma única vez eliminando erros e aumentando o controle interno

- Diminuição da informação em papel, diminuindo custos, facilitando o acesso e aumentando a eficiência e a segurança.

- Melhoria do processo administrativo

A ligação das funções internas em um único ambiente - a Intranet - facilita a administração e coordenação dos negócios. Estas funções podem ainda estar integradas aos parceiros de negócio constituindo uma Extranet.

\subsection{Extranet}

Turban, Lee, King e Chung (2002) definem extranet como sistemas de informação que ligam parceiros de negócios, conectando a intranet da empresa à intranets de seus fornecedores, distribuidores, serviços financeiros, governos e clientes. $\mathrm{O}$ acesso é limitado por acordos de colaboração entre as partes e controlado rigorosamente.

A transmissão das informações nas extranets pode ser feita utilizando linhas alugadas ou a Internet. As linhas alugadas são seguras enquanto a Internet oferece pouca privacidade e segurança de transmissão. A tecnologia de tunelamento é capaz de aumentar a segurança da Internet criando túneis onde o fluxo de dados é seguro. Extranet associada a tecnologia de tunelamento constitui as Rede Privada Virtual (VPN) (TURBAN; LEE; KING; CHUNG, 2002). 
Além da questão da segurança, a eficácia da extranet depende do grau de integração com os sistemas e bancos de dados existentes e da coordenação intensa da empresa e seus parceiros de negócio. As diferenças técnicas entre os sistemas são fontes de conflito freqüentes e, muitas vezes, impendem ou dificultam a troca de informação.

As extranets são compostas de: intranets, servidores Web, firewalls, Provedores de Serviço Internet, tecnologia de tunelamento, software de interface e aplicativos de negócios. A figura abaixo ilustra a arquitetura da extranet (TURBAN; LEE; KING; CHUNG, 2002).

\section{Figura 14 - Arquitetura da extranet}

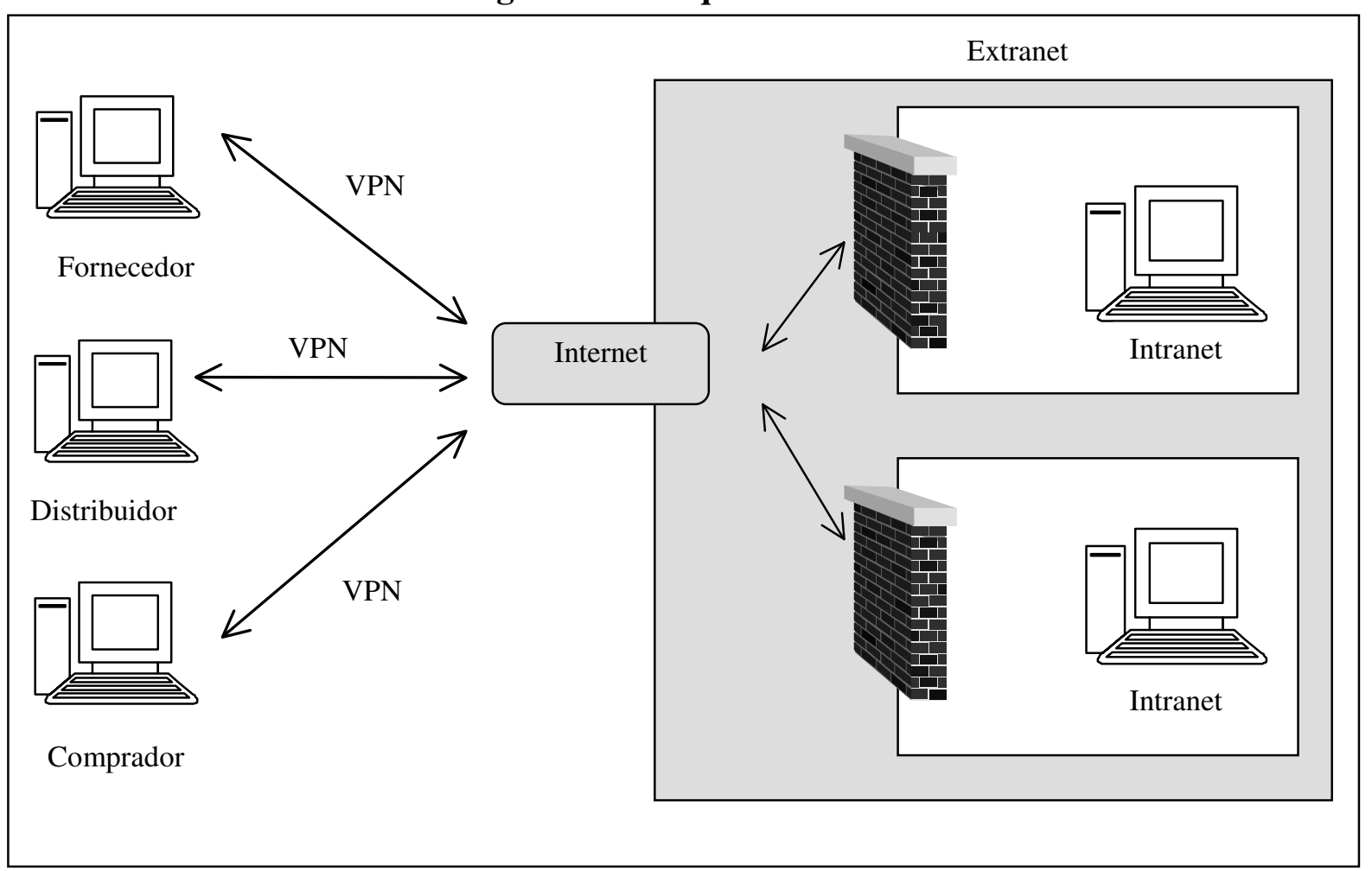

Fonte: adaptado de Turban, Lee, King e Chung (2002).

Turban, Rainer e Potter (2003) classificam a extranet em:

- Foco na empresa: clientes e fornecedores acessam a extranet da empresa para, no caso do primeiro, verificar o atendimento dos seus pedidos e, no do segundo, verificar a necessidade de enviar novas remessas.

- Foco no setor: empresas de um setor criam uma extranet conjunta capaz de atender a todos. Por exemplo, três empresas do setor automobilístico criaram um extranet para que os fornecedores tivessem acesso às suas necessidades. 
- Foco na parceria: empresas participantes de um empreendimento conjunto utilizam a extranet para comunicação e colaboração.

A intranet traz, portanto, inúmeros benefícios para as organizações. Estes benefícios são potencializados quando são incorporados parceiros externos constituindo, neste caso, uma extranet. Szuprowicz (2000) identificou os principais benefícios trazidos pela extranet: melhora na comunicação e nos processos de negócios, aumento da produtividade, redução de custo e maior facilidade na remessa das informações.

\section{XXX}

A infra-estrutura - hardware, software, bancos de dados e redes de telecomunicação fornece o suporte para as aplicações de TI. A seguir serão apresentados os principais aplicativos: sistemas de informação horizontais e de gestão. Os sistemas de gestão permitem a gestão integrada da empresa e o estabelecimento de ligações com seus parceiros, constituindo as redes. Finalmente, serão apresentados os Sistemas de Informação Logísticos (SIL) voltados para o desenvolvimento do trabalho logístico.

\subsubsection{Sistemas de informação horizontais}

Os sistemas de informação horizontais são construídos para atender os diferentes interesses da organização em cada um dos quatro níveis e, em cada nível, das cinco funções. Uma organização tradicional tem, geralmente, os quatro sistemas - operacionais, de conhecimento, gerencial e estratégico - para cada uma das cinco funções - vendas e marketing, produção, finanças, contabilidade e recursos humanos (LAUDON; LAUDON, 2004):

- Os sistemas operacionais dão apoio às atividades e transações de rotina das empresas como, por exemplo, vendas, receitas, depósitos, pagamentos, decisões de crédito e o fluxo de material.

- Os sistemas que atuam no nível de conhecimento têm como objetivo ajudar a empresa a integrar o conhecimento e controlar o fluxo de documentos.

- Os sistemas que operam no nível gerencial dão apoio ao monitoramento, controle, tomada de decisão e atividades administrativas dos médios gerentes.

- Os sistemas que atuam no nível estratégico ajudam os altos executivos a lidar e controlar as questões estratégicas e de longo prazo dentro da empresa e no ambiente externo. 
No quadro abaixo, estão decritos os principais sistemas que atendem os quatro níveis da organização e suas funções. O Executive Support System (EES) opera no nível estratégico, o Management Information Systems (MIS) e Decision Support Systems (DSS) no nível gerencial, Knowledge Work Systems (KWS) e Office Systems no nível de conhecimento e, finalmente, o Transaction Processing Systems (TPS) no nível operacional. Os sistemas são desenhados para atender cada uma das cinco áreas funcionais em cada nível.

\section{Quadro 4 - Sistemas de informação horizontais e funções}

\begin{tabular}{|c|c|c|}
\hline $\begin{array}{c}\text { Níveis } \\
\text { organizacionais }\end{array}$ & Tipos de sistemas & Funções \\
\hline Estratégico & Executive Support System (EES) & $\begin{array}{l}\text { Dá suporte à tomada de decisões não } \\
\text { rotineiras que exigem julgamento, avaliação } \\
\text { e compreensão. Utiliza dados do MIS e do } \\
\text { DDS, e permite a incorporação de dados } \\
\text { externos. Filtra, comprime e localiza dados } \\
\text { críticos para os executivos e não está voltado } \\
\text { para a solução de problemas específicos. }\end{array}$ \\
\hline & $\begin{array}{l}\text { Management Information Systems } \\
\text { (MIS) }\end{array}$ & $\begin{array}{l}\text { Apóia as funções de planejamento, controle e } \\
\text { tomada de decisão resumindo e elaborando } \\
\text { relatórios dos eventos de rotina e exceções. }\end{array}$ \\
\hline Gerencial & Decision Support Systems (DSS) & $\begin{array}{l}\text { Apóia na tomada de decisões. Além das } \\
\text { informações internas, utilizam fontes } \\
\text { externas como, por exemplo, preço praticado } \\
\text { pelos competidores. Tem capacidade para } \\
\text { analisar ou condensar grande quantidade de } \\
\text { dados que podem ser utilizados pelos } \\
\text { tomadores de decisão. }\end{array}$ \\
\hline \multirow[b]{2}{*}{ Conhecimento } & Knowledge Work Systems (KWS) & $\begin{array}{l}\text { Auxiliam na criação e integração de novas } \\
\text { informações e conhecimentos na organização }\end{array}$ \\
\hline & Office Systems & $\begin{array}{l}\text { Aumentam a produtividade do } \\
\text { processamento da informação dando apoio às } \\
\text { atividades de comunicação e coordenação } \\
\text { típicas de escritório. }\end{array}$ \\
\hline Operacional & Transaction Processing Systems (TPS) & $\begin{array}{l}\text { Executa e grava diariamente as transações de } \\
\text { rotina da empresa. Permite monitorar o status } \\
\text { das operações internas e a relação da empresa } \\
\text { com o ambiente externo. É também } \\
\text { importante produtor de informação para os } \\
\text { outros sistemas }\end{array}$ \\
\hline
\end{tabular}

Fonte: adaptado de Laudon e Laudon (2004).

\subsubsection{Relações entre os sistemas de informação horizontais}

Os vários tipos de sistemas são interdependentes. A figura abaixo ilustra como os sistemas estão relacionados uns aos outros. Os TPS são os principais fornecedores de dados 
enquanto os EES são, fundamentalmente, receptores dos dados dos demais sistemas. Os outros sistemas podem, também, trocar dados entre si ou mesmo entre sistemas que servem diferentes áreas funcionais (LAUDON; LAUDON, 2004).

Figura 15 - Relação entre os sistemas de informação horizontais

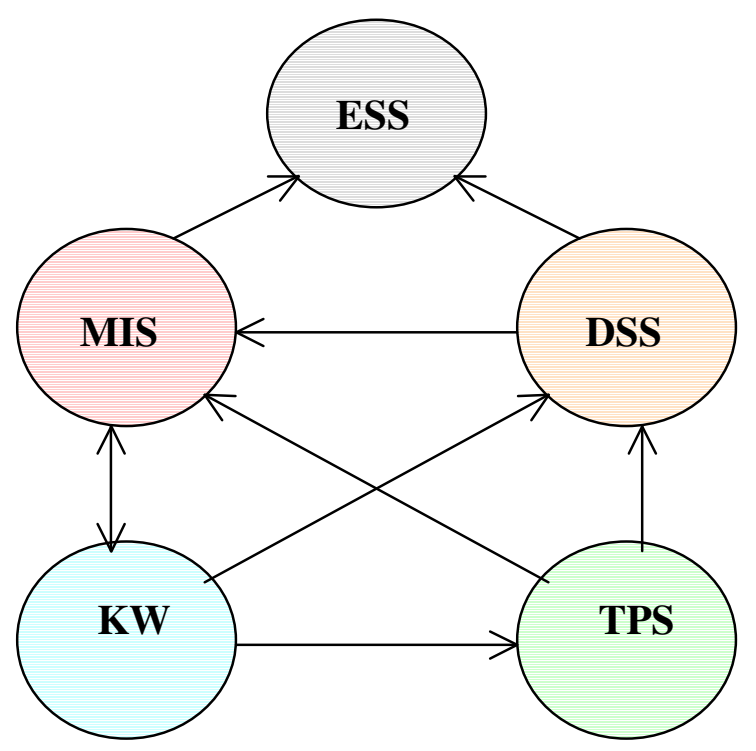

Fonte: Laudon e Laudon (2004, p. 46).

Para ser competitiva, a empresa deve integrar e coordenar os fluxos de trabalho e de informação para que ocorram de forma sincronizada. Estes objetivos exigem sistemas capazes de integrar informação das diferentes áreas funcionais e unidades organizacionais e coordenar as atividades da empresa com seus fornecedores e outros parceiros de negócio.

A integração dos sistemas é extremamente vantajosa, pois permite que a informação flua entre as diferentes partes da empresa. Mas integrar sistemas diferentes é uma tarefa complexa e dispendiosa: grande parte deles foi construída de forma isolada e não estão habilitados para trocar informações. A solução mais viável - técnica e economicamente - é a compra ou construção de um aplicativo para empresa (LAUDON; LAUDON, 2004).

\subsubsection{Sistemas de empresa}

Os sistemas de empresa são capazes de coordenar as atividades, decisões e conhecimento através de diferentes funções, níveis ou unidades de negócio na empresa. Atualmente, estes sistemas utilizam intranet e tecnologia Web, que capacita a transferência 
eficiente da informação dentro da empresa e com seus parceiros externos (TURBAN; RAINER; POTTER, 2003; LAUDON; LAUDON, 2004).

Os principais sistemas de empresa disponíveis atualmente no mercado são: Sistema Integrado de Gestão (Enterprise Resource Planning - ERP), Sistemas de Gestão da Cadeia de Suprimentos (Supply Chain Management Systems - SCM), Sistemas de Gestão de Relacionamento com Clientes (Customer Relationship Management Systems - CRM) e Sistemas de Gestão do Conhecimento (Knowledge Management Systems - KMS).

Cada um destes aplicativos integra parte das funções e processos de negócio para garantir o desempenho global da organização. Os sistemas ERP criam uma plataforma capaz de integrar e coordenar os principais processos internos da empresa. Os sistemas SCM apóiam a gestão de relacionamento da empresa com os fornecedores. Os $C R M$, com os clientes. E, finalmente, os sistemas $K M S$ ajudam a empresa a capturar e aplicar melhor seus conhecimentos e expertise (LAUDON; LAUDON, 2004).

\subsubsection{Sistemas Integrados de Gestão (Enterprise Resource Planning - ERP)}

Os Sistemas Integrados de Gestão (Enterprise Resource Planning - ERP) foram desenvolvidos nos anos 90. Estes sistemas integram e coordenam os principais processos internos de negócio. Coletam os dados de rotina da empresa - como pagamentos, finanças, estoque e processamento de pedidos, etc. - e armazenam em um único repositório que atende toda a organização (LAURINDO; MESQUITA, 2000; WANGA et al.; 2007).

Por meio do ERP a empresa administra suas atividades internas em uma interface única. As atividades vão desde a entrada dos pedidos, remessa do produto, até o serviço pósvenda. Ao receber um pedido, o ERP acessa o estoque e localiza dados do produto, histórico do cliente e informações sobre pedidos anteriores (LAURINDO; MESQUITA, 2000).

Para Laudon e Laudon (2004), os sistemas ERP podem beneficiar quatro dimensões do negócio: a estrutura da empresa, seus processos de gestão, plataforma tecnológica e a potencialidade do negócio.

- Estrutura da empresa: os sistemas ERP dão suporte à estrutura organizacional e criam uma cultura uniforme. Toda a organização utiliza as mesmas informações e processos e pode realizar negócios com o mesmo padrão em qualquer lugar do mundo.

- Processos de gestão: os sistemas ERP automatizam transações básicas, como recebimento de pedidos, pagamento de fornecedores, etc. Ainda, dão suporte na execução de relatórios e na tomada de decisão. 
- Plataforma tecnológica: os sistemas ERP utilizam um repositório integrado e único que coleta dados de todos os processos de negócio. Os dados obedecem a padrões comuns e formatos aceitos por toda a empresa e são mais precisos e atualizados.

- Potencialidade do negócio: os sistemas ERP integram os processos de negócios isolados permitindo que a organização possa atender, de forma eficiente, as necessidades dos clientes por produtos ou informação.

Os relatórios extraídos destes sistemas, entretanto, fornecem um retrato no tempo, isto é, descrevem a situação da empresa num dado momento. Assim, não são capazes de dar suporte ao exercício contínuo de planejamento e nem a tomada de decisão. No planejamento contínuo a empresa refina e adapta seus planos observando as mudanças e eventos em tempo real, questão central para gestão da cadeia de suprimentos. Portanto, o ERP tem pouca aplicação nas decisões estratégicas e de planejamento (LAUDON; LAUDON, 2004)

Para Laudon e Laudon (2004), a implantação dos sistemas ERP coloca grandes desafios para as organizações:

- Elevados investimentos em tecnologia: o tempo de implantação é elevado, exige treinamento interno e contratação de mão de obra especializada para instalação e manutenção do sistema.

- Mudanças na forma de operar dos negócios: a remodelação dos processos pode não ser adequada do ponto de vista estratégico, dificultando ou mesmo impedindo que a empresa mantenha suas vantagens competitivas.

Os sistemas ERP são complexos e de difícil construção. Existem no mercado alguns softwares comerciais, como o líder SAP. Empresas capazes de integrar com sucesso suas inúmeras aplicações funcionais utilizando software ERP obtêm economias significativas e aumentam a satisfação dos clientes.

No início o ERP focava exclusivamente na partilha dos dados internos para a operação da empresa. Desde o final dos anos 90, os sistemas ERP vêm incorporando funcionalidades que permitem a interação com os clientes, fornecedores e vendedores. Os sistemas estão sendo integrados, não só aos sistemas $E R P$ de seus parceiros, mas também aos sistemas $S C M$ e $C R M$ (KLAUS; ROSEMANN; GABLE, 2000). 


\subsubsection{Gestão da cadeia de suprimentos (Supply Chain Management - SCM) e Negócios colaborativos}

Os sistemas $S C M$ vieram para complementar as deficiências dos sistemas ERP. Estes sistemas são sobrepostos ao sistema ERP da empresa, utilizando os dados gerados por eles em cada etapa da cadeia, e dando suporte à tomada de decisão (AROSO, 2003).

Segundo Aroso (2003), os sistemas SCM apóiam a gestão do relacionamento da empresa com seus parceiros, integrando fornecedores, produtores, distribuidores e o processo logístico com o objetivo de eliminar duplicação de esforços, reduzir estoques e o templo do ciclo do pedido.

As ineficiências na cadeia - como insuficiência de materiais, subutilização da capacidade, estoque em excesso ou alto custo de transporte - são causadas por informações imprecisas ou desatualizadas. Os sistemas SCM tornam mais eficiente a gestão da cadeia de suprimentos porque permitem a coordenação das atividades de compra, produção, estoques e remessa dos produtos.

A implantação do SCM pressupõe uma relação de confiança entre os parceiros. Todos devem cooperar e honrar os compromissos mútuos, trabalhar em harmonia visando o bem comum e reestruturar alguns de seus processos de negócio para facilitar a integração e coordenação.

O negócio colaborativo é a utilização da tecnologia para realizar e desenvolver projetos, produzir, movimentar e administrar os produtos de forma compartilhada. As empresas estão investindo neste tipo de relacionamento para melhorar o planejamento, produção e distribuição de bens e serviços (AROZO, 2003).

O objetivo destes sistemas é mais amplo que o SCM. Enquanto o SCM está voltado para a gestão do fluxo de transações entre as organizações, o negócio colaborativo foca na partilha de sistemas e processos de negócios para otimizar o valor dos relacionamentos.

Os negócios colaborativos permitem redução no tempo necessário para o desenvolvimento dos produtos, maior precisão nas previsões de demanda e atualização constante das informações. 


\subsubsection{Gestão de Relacionamento com Cliente (Customer Relationship Management - CRM)}

Os sistemas CRM dão suporte à gestão do relacionamento da empresa com seus clientes. Apóiam o cliente desde o recebimento do pedido até a remessa do produto. Integram os processos das funções vendas, marketing e serviços e consolidam a informação destas fontes para fornecer uma visão única dos clientes. Com estas informações as empresa podem oferecer serviço de melhor qualidade, customizar seus produtos, oferecer mais valor e conquistar novos clientes (NAZÁRIO, 2004).

\subsubsection{Sistemas de Gestão do Conhecimento (Knowledge Management Systems - KMS)}

Os sistemas $K M S$ coletam conhecimento e experiências importantes da empresa e de fontes externas e disponibilizam para apoiar processos de negócio e a tomada de decisão. Utilizando estes sistemas os gerentes podem, rapidamente, tomar a decisão de forma mais segura.

Estes sistemas são capazes de identificar padrões e relações em grandes volumes de dados. Ajudam, também, na identificação, codificação, partilha e distribuição de conhecimento e na sua integração na organização.

Existe forte relação entre os sistemas $E R P$ e os $K M S$. Os sistemas $K M S$ precisam, para operar adequadamente, acesso aos dados fornecidos pelo ERP. E os sistemas ERP, por sua vez, só podem desenvolver todo o seu potencial quando utilizados pelos $K M S$ (KANAKAMEDALA; RAMSDELL; SRIVATSAN, 2003; NAZÁRIO, 2004).

\section{XXX}

Os sistemas de empresa possibilitam a integração interna das empresas e a coordenação de suas atividades com fornecedores, clientes e outros parceiros de negócio. Mas, a utilização da TI para a gestão integrada da logística ultrapassa a integração interna e o estabelecimento de interface com os demais agentes da cadeia proporcionada pelos sistemas de empresa. Devem, ainda, ser estudados os sistemas de informação que conectam diferentes organizações, também chamados de sistemas de informações interoganizacionais. 


\subsection{Sistemas de Informação Interorganizacionais (Information Organization Systems - IOS)}

As empresas mantêm vários tipos de sistemas de informação dando apoio a diferentes funções, processos e níveis das organizações. Há quarenta anos atrás os sistemas eram totalmente isolados, sem nenhuma comunicação entre si (SHORE, 2001). A dispersão dos dados em sistemas isolados e a ausência de integração e coordenação resultavam em ineficiências e desempenho insatisfatório nos negócios. A partir dos anos 80, como resultado dos avanços das telecomunicações e da computação, desenvolveram-se os Sistemas de Informação Interorganizacionais (TURBAN; LEE; KING; CHUNG, 2002).

Os IOS são sistemas que automatizam o fluxo de informação além dos limites da organização. Ligam a empresa aos seus clientes, distribuidores e fornecedores alterando de forma importante o acesso a informação e a forma de comunicação entre empresas. Estes sistemas distribuem as informações utilizando redes de telecomunicação. $\mathrm{O}$ desenvolvimento das tecnologias de rede possibilitou a transmissão eletrônica de documentos entre as organizações (TURBAN; LEE; KING; CHUNG, 2002).

\subsubsection{Intercâmbio eletrônico de dados (Electronic Data Interchange - EDI)}

O Intercâmbio eletrônico de dados (Electronic Data Interchange - EDI) é um sistema de envio e recebimento de documentos eletrônicos padronizados entre parceiros de negócios. Estes documentos são gerados a partir de dados das transações comerciais rotineiras tais como pedidos, faturas, aprovação de crédito, aviso de embarque, etc. Os documentos são transmitidos diretamente entre os sistemas de computadores de diferentes empresas por meio das redes de comunicação (TURBAN; LEE; KING; CHUNG, 2002; LAUDON; LAUDON, 2004).

Segundo Laudon e Laudon (2004), a utilização do EDI traz vários benefícios para as empresas. Dentre eles:

- Capacita a enviar e receber, rapidamente, grande quantidade de informações sobre transações de rotina.

- Diminui a ocorrência de erros, já que a transferência de dados é feita computador a computador.

- Permite que a informação possa fluir entre inúmeros parceiros de negócios. 
- Permite acesso das empresas aos bancos de dados dos parceiros para recuperar e armazenar informações.

- Incentiva o estabelecimento de parcerias reais e estratégicas já que envolve um compromisso de investimentos e a adequação dos sistemas ao longo do tempo

- Cria um ambiente sem a utilização de papel, aumentando a eficiência e reduzindo custos.

- Permite a utilização imediata dos dados, logo após o recebimento.

- Permite o envio das informações sobre as vendas para os produtores, distribuidores e armazéns quase em tempo real.

- Pode reduzir significativamente os custos.

Uma questão importante na comunicação eletrônica entre sistemas computacionais está nos diferentes formatos de arquivos, esquemas relacionais, protocolos de troca de dados, etc. utilizados pelas empresas. Estas diferenças dificultam, ou mesmo impedem, a troca eletrônica de dados entre diferentes sistemas: o destinatário tem que reconhecer a estrutura da mensagem para ser capaz de receber e de tratar os dados de forma automatica.

Nas últimas décadas, foram feito vários esforços para a padronização de modo a viablizar a troca eletrônica de documentos. Muitos padrões foram desenvolvidos para comunicação EDI, entre eles X12, ODETTE, etc. No final dos anos oitenta, a Organização das Nações Unidas (ONU) desenvolveu a EDIFACT, um padrão mais completo e complexo que os anteriores e que vem sendo adotado pela maioria das empresas em todo o mundo (LAUDON; LAUDON, 2004).

\subsubsection{EDI tradicional e EDI apoiado na Web}

O EDI já vem sendo utilizado pelas organizações há cerca de trinta anos, mesmo antes da existência da Internet. No início, o EDI utilizava para a transmissão de documentos redes de valor agregado $(V A N s)$. As $V A N s$ ofereciam segurança e alta capacidade, mas tinham custos bastante elevados. Turban, Lee, King e Chung (2004) denominam o EDI utilizando VANs de EDI tradicional.

Segundo os autores, o EDI tradicional permitiu a redefinição das relações com clientes e fornecedores utilizando práticas como resposta rápida e produção just in time. Trouxe enormes benefícios para as empresas, tornando-se um elemento essencial. Entretanto, apresenta alto custo, exige a reestruturação dos processos de negócio e tempo longo para implantação. Por seu alto custo, seu uso estava restrito às grandes empresas. 
O desenvolvimento do EDI apoiado na Internet mudou esta realidade. A Internet substituiu as caras VANs e diminuiu significativamente os custos para a utilização do EDI. Isto porque é uma rede pública, de códigos abertos e fácil conectividade. As conexões globais da Internet permitem atingir mais parceiros do que qualquer alternativa antes disponível e suas ferramentas são amigáveis e de fácil utilização.

A figura abaixo ilustra o EDI tradicional e o EDI apoiado na Internet.

Figura 16 - EDI tradicional e EDI apoiado na Web

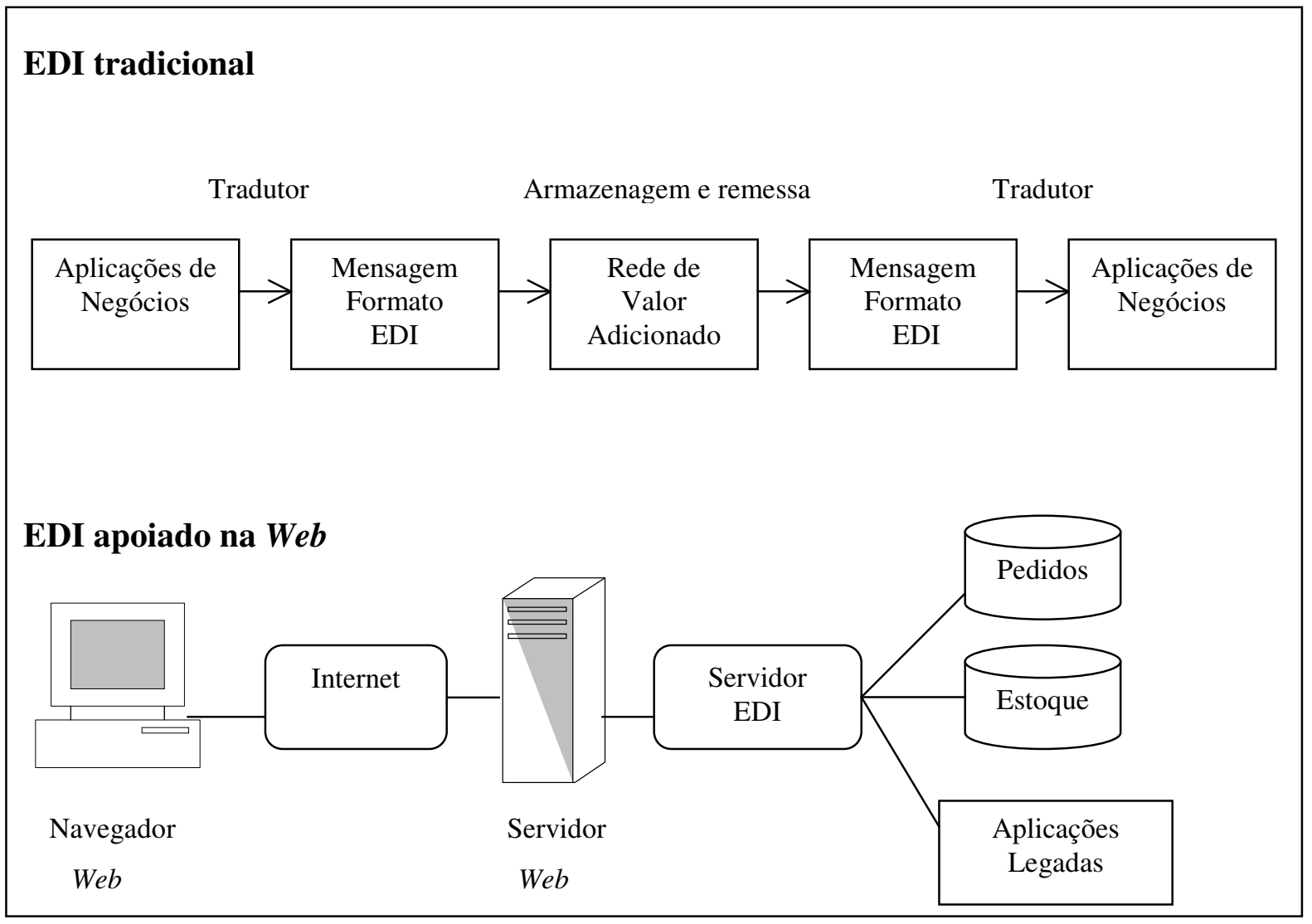

Fonte: Turban, Lee, King e Chung (2004: 259).

Embora a tendência das empresas seja migrar das VANs e linhas alugadas para a internet, com freqüência encontram-se organizações utilizando simultaneamente EDI tradicional e o EDI apoiado na Internet. Neste caso, as informações fluem pela Internet, sendo depois transmitidas para uma $V A N$ ou provedor de serviço que converte os dados para o padrão EDI e remete para os computadores da empresa (TURBAN; LEE; KING; CHUNG, 2004). 


\section{XXX}

Dentre os diversos sistemas de informação interorganizacionais existentes, de especial interesse para a tese são aqueles desenvolvidos para atender as necessidades logísticas chamados Sistemas de Informação Logísticos (SIL). Além destes sistemas, são também importantes o entendimento das novas práticas de gestão possibilitadas pela evolução tecnológica e pela sofisticação da logística - chamados Programas de Resposta Rápida (PRRs) (WANKE, 2004).

\subsubsection{Sistemas de Informação logísticos}

Sistemas de Informação Logísticos (SIL) são sistemas que medem, controlam e gerenciam as operações logísticas, tanto dentro da empresa, como ao longo da cadeia de suprimentos (NAZARIO, 2002).

A seguir serão apresentados os SIL mais utilizados no desenvolvimento do trabalho logístico. São eles: Planejamento das Necessidades de Distribuição (Distribution Requirements Planning - DPR), Sistemas de Gerenciamento de Transporte (Transportation Management Systems - TMS), Sistemas de Gerenciamento de Armazéns (Warehouse Management System - WMS), Sistemas de Informação Geográficas (Geographic Information Systems - GIS), Sistemas de Geo-posicionamento (Geo-positioning Systems - GPS), Código de Barras e Coletores de dados, e Identificação por Radiofreqüência (Radio Frequency Identification - RDIF).

\subsubsection{Planejamento das Necessidades de Distribuição (Distribution Requirements} Planning - DPR)

O $D P R$ é um sistema cujo objetivo é a manutenção de um nível adequado de estoque em um ambiente com vários armazéns servindo a diferentes localidades geográficas. Os estoques e os planos de remessa são revistos periodicamente (ENNS; SUWANRUJI, 2000).

Segundo os autores, o sistema $D P R$ utiliza a mesma lógica do $M R P$ de captar a demanda e formar uma projeção de estoque para cada nível. A diferença é que está voltado para a distribuição de bens acabados em localidades dispersas e não de materiais dentro de uma fábrica. 
A demanda nos estágios mais relacionados ao usuário final é tratada como independente, enquanto a demanda nos estágios a montante é tratada como dependente. Para antecipar as necessidades de estoque nos níveis de demanda independente, o sistema utiliza a previsão. E, nos estágios a montante, a lógica baseada no tempo.

Os níveis de estoque e o tempo necessário de reposição são, ainda, utilizados para a realização dos pedidos, minimizando os estoques. Os sistemas DPR são considerados próativos porque o estoque é planejado ao longo da cadeia de suprimentos baseado na antecipação da demanda.

Enns e Suwanruji (2000) identificam como benefícios do DPR a redução de estoque, um melhor serviço ao cliente e compatibilidade com outros sistemas dentro da cadeia de suprimentos. Como aspectos negativos, seu custo elevado.

\subsubsection{Sistemas de Gerenciamento de Transporte (Transportation Mangement Systems -} $T M S)$

Os TMS ajudam na administração do transporte de mercadorias com o objetivo de otimizar os recursos utilizados. Estes sistemas dão suporte ao planejamento, execução, monitoramento e controle das atividades relativas a consolidação de carga, expedição, emissão de documentos, entregas e coletas de produtos, rastreabilidade da frota e de produtos, auditoria de fretes, apoio à negociação, planejamento de rotas e modais, monitoramento de custos e nível de serviço, e planejamento e execução de manutenção da frota (NAZÁRIO, 2004; KANAKAMEDALA; RAMSDELL; SRIVATSAN, 2003).

\subsubsection{Sistemas de Gerenciamento de Armazéns (Warehouse Management Systems - WMS)}

O WMS é um sistema de gestão de armazéns, depósitos e centros de distribuição que otimiza todas as atividades operacionais (fluxo de materiais) e o fluxo de informação do processo de armazenagem. Inclui as atividades de recebimento, inspeção, endereçamento, armazenagem, separação, embalagem, carregamento, expedição, emissão de documentos e controle de estoque (BARROS, 2005). O WMS pode ser um módulo presente nos sistemas ERP ou ser comercializado a parte.

Os WMS são uma evolução dos antigos Sistemas de Controle de Armazéns (Warehouse Control Systems - WCS). Enquanto os WCS limitavam-se a controlar as 
transações de entrada e saída do estoque e a respectiva baixa destas movimentações na ocorrência de pedidos de fornecedores e clientes, os WMS são sistemas possibilitam a otimização operacional através do aumento da produtividade, otimização dos espaços e melhoria da utilização dos recursos, tais como equipamentos de movimentação e estocagem (BARROS, 2005; NAZÁRIO, 2004).

O WMS é capaz de disponibilizar informações em tempo real. Desta forma é possível reduzir lead-time tanto do processamento de pedidos como do gerenciamento de estoques. Com informações mais precisas e atualizadas, os WMS possibilitam a redução dos custos e melhora na operação e no nível de serviço aos clientes. As reduções de custo decorrem do uso mais eficiente dos recursos operacionais. O nível de serviço ao cliente superior da diminuição de erros e falhas na separação e remessa e de uma maior agilidade no fluxo de materiais e informações (BARROS, 2005; NAZÁRIO, 2004).

\subsubsection{Sistemas de Informação Geográfica (Geografic Information Systems - GIS)}

O GIS é um sistema de informação que trata a informação espacial. Relaciona atributos e características de uma área à sua localização geográfica. É utilizado em uma variedade de aplicações, incluindo exploração, demografia, rastreamento e confecção de mapas. Por meio de satélites e fotografias aéreas é possível desenvolver mapas digitais que podem ser combinados com camadas de informação.

\subsubsection{Sistemas de Geo-posicionamento (Geo-positioning Systems - GPS)}

O sistema GPS foi desenvolvido pelo departamento de defesa dos EUA e é formado por 24 satélites que estão em órbita ao redor da Terra e os aparelhos utilizados para recepção de seus sinais. Os satélites transmitem continuamente sinais de rádio com a sua localização e o tempo gasto para o aparelho receptor receber os sinais. Baseados nestas informações, os receptores identificam a posição de qualquer veículo ou pessoa através da sua latitude e longitude geográfica e de mapas digitalizados.

Atualmente os receptores podem estar embutidos nos mais diferentes aparelhos: computador de mão, telefone celular, relógios e notebooks. Mas, também, existem receptores dedicados exclusivamente à recepção do sinal como, por exemplo, rastreadores de veículos (KLEPPNER, 1997). 


\subsubsection{Coletores de dados}

Os coletores de dados são dispositivos que permitem a leitura automática de etiquetas eletrônicas, estejam as informações armazenadas na tecnologia de códigos de barra ou utilizando a identificação por radiofreqüência (TURBAN; LEE; KING; CHUNG, 2004):

- Código de Barras: é uma representação da informação que pode ser lida por máquinas. Pode armazenar diversas informações como lote de produção, código de identificação, preço, etc. A leitura e coleta das informações armazenadas nestes códigos são feitas, geralmente, por equipamentos denominados scanner.

- Identificação por Radiofreqüência (Radio Frequency Identification - RFID): é uma tecnologia de coleta de dados sem fio que utiliza etiquetas eletrônicas para armazenar dados. Estas etiquetas eletrônicas permitem a identificação dos produtos. Enquanto os códigos de barra precisam estar próximos do scanner para serem lidos, para as etiquetas $R F I D$ basta estarem dentro do alcance de transmissão do sinal de rádio.

Enquanto os códigos de barra contêm somente a identificação do produto, as etiquetas RFID são capazes de armazenar outros dados, permitindo o rastreamento dos produtos individualmente. São utilizadas em bibliotecas, em lojas de varejo e no acompanhamento de animais vivendo na natureza (BROWN; RUSSEL, 2007).

\subsubsection{Programas de resposta rápida (PPRs)}

A evolução tecnológica e o estabelecimento de parcerias vêm contribuindo para o desenvolvimento de novas práticas de gestão entre os agentes da cadeia. A idéia é que uma maior visibilidade dos eventos permite reduzir substancialmente os estoques e aprimorar a qualidade dos serviços (AROZO, 2003).

Conhecidos como Programas de Resposta Rápida (PRRs), estes práticas logísticas estão apoiados na cooperação e na partilha das informações entre os parceiros na cadeia de suprimentos. A partilha das informações permite melhorar (WANKE, 2004):

- As previsões e a programação de produção em políticas empurradas de gestão de estoque.

- A distribuição para a adoção do ressuprimento enxuto, onde os estoques são reabastecidos em pequenas quantidades de forma freqüente.

Existem, atualmente, várias modalidades de $P R R$ s que podem ser implantadas entre fabricantes, varejistas e fornecedores. Wanke (2004) descreve os principais. São eles: Just in time (JIT), Planejamento das Necessidades de Material (Materials Requirements Planning - 
MRP), Planejamento dos Recursos de Produção (Manufacturing Resources Planning - MRP

II), Resposta Rápida (Quick Response - QR), Reabastecimento Contínuo (Continuous Replenishment - CR), Resposta Eficiente ao Consumidor (Efficient Consumer Response $E C R$ ), Estoque Administrado pelo Fornecedor (Vendor Managed Inventory - VMI), Planejamento Colaborativo, Previsão e Reabastecimento (Collaborative Planning, Forecasting and Replenishment - CPFR), Business Intelligence (BI), E-procurement e Comércio Eletrônico.

\subsubsection{Just-in-time (JIT)}

Just-in-time (JIT) é uma técnica de gestão que utiliza conceitos diferentes dos utilizados na produção tradicional, sobretudo no que se refere ao planejamento da produção, controle de estoques e distribuição (NAZÁRIO, 2004).

Criado pela Toyota nos anos 40, o JIT tem como objetivo produzir a quantidade certa, do item certo, no tempo certo. Certo, neste caso, significa exatamente o necessário. Assim, é capaz de minimizar os estoques, melhorar a qualidade do produto, maximizar a eficiência da produção e fornecer ao cliente serviço de qualidade (SLACK, 1997).

A utilização desta técnica exige que a entrega da produção seja feita em pequenos lotes e com maior freqüência que outras formas de administração da produção. Coloca, portanto, grandes desafios para a gerência da logística. Entre eles (CRISTOPHER, 1997):

- Planejamento e programação das necessidades

- Interação entre os parceiros da cadeia de suprimentos

- Utilização de parceiros logísticos terceirizados

O JIT está apoiado em várias tecnologias. Entre elas: EDI, códigos de barra e sistemas de informação que permitam intensa troca de informação entre os parceiros.

\subsubsection{Just-in-time II (JIT II)}

O Just-in-time II é uma extensão do JIT para fora dos limites da empresa. Foi desenvolvido com o objetivo de estreitar a comunicação entre comprador e vendedor, reduzindo desperdícios e a redundância de esforços, além aumentar a eficiência do fornecedor (NAZÁRIO, 2004).

O fornecedor disponibiliza um funcionário para trabalhar junto ao seu cliente. Este funcionário, denominado in-plant, decide a programação de produção e aquisição de insumos, 
além de dedicar parte de seu tempo a projetos de engenharia simultânea. Desta forma, substitui as funções do comprador e do planejador no cliente e as do vendedor no fornecedor.

\subsubsection{Planejamento das Necessidades de Material (Materials Requirements Planning - MRP)}

O Planejamento das Necessidades de Material (Materials Requirements Planning $M R P)$ é um método para programação de abastecimento da produção. Calcula a quantidade de matéria prima e intermediária necessária em cada estágio da cadeia de suprimentos por meio de relações pré-definidas de entradas e saídas. Neste método, as compras e a saída da produção são sincronizadas para satisfazer as necessidades operacionais a cada período, equilibrando a necessidade de suprimentos com o tempo de reabastecimento e reduzindo os estoques (BALLOU, 2001).

Os cálculos envolvidos neste método são bastante trabalhosos. Em meados dos anos 70 surgiram os sistemas MRP que, com o apoio de computadores, formalizava o método utilizado nas empresas, calculando as necessidades de diferentes materiais ao logo do tempo. O sistema MRP planeja o fluxo de peças, materiais e suprimentos para que o abastecimento ocorra de acordo com a necessidade de produção (LAURINDO; MESQUITA, 2000; REYES; RAISINGHANI; SINGH, 2002; PESSOA; NOGUEIRA, 2006).

Os sistemas MRP apresentam algumas limitações (LAURINDO; MESQUITA, 2000).

Primeira, como calcula os materiais necessários para suprir o processo de fabricação baseado na previsão de demanda, pode haver descompasso entre a quantidade de produto acabado que a empresa produz e a demanda efetiva do mercado. Para evitar esta situação, é preciso que a empresa produza, distribua e venda produtos como planejado inicialmente.

Segunda, não considera o planejamento de recursos financeiros e das operações, ambos intimamente relacionados ao controle dos estoques. Buscou-se, então, integrar estas duas operações ampliando a metodologia e o software para o que veio a ser o MRP II.

\subsubsection{Planejamento dos Recursos de Produção (Manufacturing Resource Planning - MRPII)}

Segundo Laurindo e Mesquita (2000), o Planejamento dos Recursos de Produção (Manufacturing Resource Planning - MRPII) é um sistema integrado que vincula o MRP tradicional a outras áreas funcionais, como finanças e recursos humanos. 
O MRPII calcula os custos dos materiais, manutenção de equipamentos, energia, etc. e o fluxo de caixa necessário para os pagamentos. Integra os processos de gestão da produção e dos negócios e é utilizado no planejamento de médio e longo prazo. O MRP II evolui para os sistemas ERP.

\subsubsection{Resposta Rápida (Quick Response - QR)}

No modelo QR de gestão, os fornecedores recebem os dados coletados nos pontos de vendas dos clientes e, a partir deles, sincronizam suas operações de produção e seus estoques. Os fornecedores utilizam os dados para aprimorar a previsão de vendas e a programação de produção. O modelo QR também tem impacto sobre as operações de distribuição: os produtos passam a ser movimentados através de instalações de cross-docking e não são mais armazenados em centros de distribuição (WANKE, 2004).

No cross-docking o produto acabado é coletado na fábrica e remetido diretamente ao cliente com pouca ou nenhuma operação entre estas etapas. Desta forma reduz a operação e armazenagem de estoques e praticamente elimina a utilização de armazéns antes da remessa do produto. Recebe o produto e remete quase que imediatamente sem que haja armazenagem. Isto porque o estoque que é movimentado nestas instalações destina-se a atender um pedido já realizado pelo varejista na cadeia de suprimentos. Assim, no cross-docking a cadeia de suprimentos é dirigida pela demanda (WANKE, 2004).

\subsubsection{Reabastecimento Contínuo (Continuous Replenishment - CR)}

No modelo $C R$ os fornecedores recebem os dados provenientes dos pontos de venda e preparam carregamentos em intervalos regulares. O objetivo é manter o estoque do cliente flutuando em um dado intervalo (WANKE, 2004).

\subsubsection{Resposta Eficiente ao Consumidor (Efficient Consumer Response - ECR)}

O modelo de gestão ECR surgiu na indústria de alimentos americana. Fornecedores e donos de supermercados comprometeram-se a cooperar em cinco áreas: compartilhamento das informações em tempo real, gerenciamento das categorias, reabastecimento contínuo, padronização e custeio baseado nas atividades. O compartilhamento das informações permite a montagem dos carregamentos com o mix correto de produtos e na seqüência adequada. $\mathrm{O}$ 
gerenciamento de categorias permite agrupar os produtos de acordo com suas características mercadológicas. O reabastecimento contínuo permite o gerenciamento just-in-time dos estoques que passam a ser movimentados em instalações cross-docking. A padronização estabelece normas e rotinas para a operacionalização do fluxo de produtos e informações. E, finalmente, o custeio baseado nas atividades permite quantificar as melhorias operacionais obtidas através do modelo de gestão ECR (WANKE, 2004).

\subsubsection{Estoque administrado pelo Fornecedor (Vendor Managed Inventory - VMI)}

Segundo Wanke (2004), VMI é um sistema de gestão que permite aos fornecedores administrar os estoques e reabastecer seus clientes quando necessário. Os fornecedores rastreiam os produtos em estoque dos distribuidores e varejistas e verificam a necessidade de reabastecimento.

O VMI está apoiado na tecnologia de informação, sobretudo o EDI. De forma geral, os fabricantes realizam uma revisão diária do estoque a partir do arquivo EDI remetido pelo distribuidor. Os produtos são remetidos automaticamente somente quando necessário, diminuindo os estoques nos centros de distribuição e lojas. Fornecedores e compradores utilizam contratos para determinar pagamento, freqüência de reabastecimento e outros termos do acordo (WANKE, 2004).

A indústria de vestuário foi a pioneira no uso do VMI, seguida pelas lojas de departamentos e, por fim, os supermercados. Os supermercados demoraram mais para adotar a tecnologia porque o número de itens disponíveis torna mais complexo o rastreamento e a utilização dos dados de venda.

Durante muitas décadas, VMI era totalmente manual. Vendedores faziam levantamento dos estoques quando visitavam seus clientes. Lojas de departamento, como a Wal-Mart, moveram-se para VMI automatizados no final dos anos 80. Um dos fatores motivadores foi a dificuldade de predizer a necessidade sazonal de roupas (SIMATUPANG; SRIDHARAN, 2002)

A maioria dos fabricantes não tem integrado o VMI aos seus sistemas ERP porque os vendedores de software não construíram interfaces entre os dois tipos de sistemas (WANKE, 2004). 


\subsubsection{Planejamento colaborativo, previsão e reabastecimento (Collaborative Planning, Forecasting and Replenishment - CPFR).}

Segundo Wanke (2004), neste modelo de gestão, fabricantes e varejistas compartilham não só os sistemas, como também, seus processos de previsão de vendas e planejamento do ressuprimento ou produção. Difere dos demais modelos de PRR porque, enquanto estes estão focados no fluxo de informações baseado na demanda real do consumidor final, o foco do CPFR é o planejamento colaborativo entre as empresas participantes da cadeia de suprimentos.

O CPFR busca aumentar a eficiência nas cadeias de suprimentos, especialmente no setor varejista, estabelecendo normas e procedimentos que facilitam o fluxo dos bens físicos e das informações. Os fabricantes, distribuidores e varejistas, subordinados às normas e procedimentos, estabelecem objetivos comuns e desenvolvem planos operacionais e de vendas de forma compartilhada. O planejamento conjunto permite sincronizar o ciclo de compras dos clientes com a produção (CHEN; YANG; CHIA, 2007).

\subsubsection{Business Intelligence (BI)}

BI é uma ampla categoria de aplicativos e tecnologias para captar, armazenar, analisar e prover acesso a dados que ajudam as empresas a melhorar a tomada de decisões de negócio. Incluem as atividades do sistema de apoio à decisão, pesquisa e relatórios, processo analítico online, análise estatísticas, previsão e Data Mining. Data Mining é um processo analítico que permite explorar grandes quantidades de dados buscando relações ou padrões consistentes entre as variáveis e, então, aplicando os padrões detectados à novos dados (NAZÁRIO, 2004).

\subsubsection{E-procurement}

E-procurement é um termo utilizado para descrever a utilização de métodos eletrônicos nos diversos estágios do processo de compra, indo desde a identificação da necessidade até o pagamento. Inclui a pesquisa de produtos, comparação de preços e características técnicas, levantamento de estoque, consulta e solicitação de informações, realização de encomendas e compras online. O conceito de e-procurement identifica uma relação de um para muitos, ou seja, um fornecedor e vários clientes. O conceito de e-market, por sua vez, identifica uma relação de muitos para muitos. Os portais de e-procurement 
apresentam, de forma geral, as empresas compradoras de um lado e os fornecedores de outro (NAZÁRIO, 2004).

\section{XXX}

Foi apresentado, neste capítulo, o papel da TI enquanto infra-estrutura, e identificados e analisados os principais aplicativos disponíveis no mercado:

- Enquanto infra-estrutura: foram apresentados os elementos que constituem a plataforma tecnológica de suporte aos aplicativos: hardware, software, tecnologia de armazenagem e redes de telecomunicações.

- Enquanto aplicativos: foram descritos os diversos sistemas de empresa existentes e como vêm sendo utilizados na logística.

No início, a TI melhorou os componentes físicos das atividades e facilitou o processamento de informação nas empresas. Mais tarde, permitiu a integração dos processos internos e, finalmente, a integração dos processos da empresa com os de outras organizações, possibilitando o estabelecimento das redes (APPLEGATE; AUSTIN; MCFARLAN, 2003).

$O$ processo de integração interna, em sua fase inicial, estava apoiado no desenvolvimento de interfaces para troca de dados entre sistemas legados independentes. Mais tarde, o desenvolvimento dos Sistemas Integrados de Gestão (ERPs) permitiram a integração dos dados e processos internos das empresas. Atualmente, apoiados nos avanços das telecomunicações e da computação, os sistemas ultrapassaram os limites das organizações, integrando diferentes empresas por meio de rede (LAURINDO; MESQUITA, 2002).

Assim, o papel da TI vai além da compreensão de suas ferramentas. A TI vem ocupando, cada vez mais, um importante papel estratégico nas empresas. A seguir serão apresentados alguns elementos que podem auxiliar na análise do papel estratégico das tecnologias.

\subsection{Papel estratégico da TI}

Diversos autores discutem a importância estratégica da TI para as empresas. A revolução da informação reduziu de forma drástica o custo de obtenção, processamento e transmissão das informações, com conseqüências diretas sobre a forma como os negócios são realizados (PORTER, 2001). 
Para Porter (2001), a TI é estratégica porque tem potencial para transformar a forma de execução das atividades e os elos existentes entre elas. Mas ressalta que seu papel e importância são diferentes para os diferentes setores: é mais estratégica quanto mais intensivos em informação forem os produtos e processos.

Além de transformar os produtos e processos, a TI também afeta as regras de competição. Porter (1999) constatou, a partir de levantamentos em várias indústrias, que a TI está mudando as regras de competição de três maneiras:

- Modificando a estrutura industrial: a TI pode modificar as relações entre as cinco forças que compõem a estrutura, podendo, desta forma, alterar a rentabilidade.

- Criando vantagens competitivas: a TI pode afetar custo, diferenciação e escopo de competição.

- Custo: pode diminuir os custos em qualquer parte do processo produtivo e alterar a posição relativa da empresa. Isto é possível por meio da integração das funções similares e eliminação das atividades desnecessárias (NARASIMHAN; KIM, 2001).

- Diferenciação: as tecnologias permitem que as empresas desenvolvam um posicionamento estratégico único. As empresas podem oferecer produtos e serviços personalizados e com qualidade elevada mantendo-se competitivas em preço (VENKATRAMAN, 1994).

- Escopo: permite que a empresa coordene suas atividades em termos regionais, nacionais e globais; estabeleça ligações entre setores antes segregados como, por exemplo, TI e telecomunicação, e torne possível a segmentação dos produtos mesmo quando a empresa possui amplas linhas.

- Promovendo novos negócios: a TI pode criar novas oportunidades de negócios de três maneiras:

- Viabilizando novos negócios em termos tecnológicos. O desenvolvimento de novos produtos pode deslocar a empresa para novas indústrias. Por exemplo, o avanço da microeletrônica permitiu o desenvolvimento da computação pessoal.

- Difundindo novos negócios por meio das demandas derivadas para novos produtos. Por exemplo, a difusão da TI criou demanda crescente por serviço de troca de informação por meio de rede de comunicação de dados.

- Criando novos negócios dentro de setores tradicionais. Por exemplo, criação e comercialização das informações geradas nas operações da empresa.

Porter (1999) conclui propondo um roteiro para avaliar a importância estratégica da TI nos diferentes setores. O roteiro aponta a necessidade de análise dos seguintes elementos: 
- Intensidade de informação nos produtos e processos;

- Transformação da estrutura setorial;

- Capacidade para criar vantagens competitivas;

- Potencial para gerar novos negócios.

A partir desta avaliação, é possível desenvolver um plano para explorar todo o potencial da TI. "Este plano deve ordenar os investimentos estratégicos necessários em hardware e software, assim como nas atividades de desenvolvimento de novos produtos que reflitam o crescente conteúdo de informação nos produtos" (PORTER, 1999, p. 105).

\subsection{Papel da TI no estabelecimento das redes de empresas}

Bowersox (1989) e Venkatraman (1994) apontaram em seus estudos o caráter evolutivo inerente ao processo de integração. Para Bowersox (1989), a integração deve ser estabelecida pela contínua automação e padronização das funções logísticas internas, seguida pela partilha de informação para, finalmente, estabelecer links estratégicos com parceiros de negócio. Para Venkatraman (1994), os estágios mais elevados de integração pressupõem, necessariamente, passagem das empresas pelos estágios inferiores.

Venkatraman (1994) classifica o processo de integração em cinco níveis:

- Exploração localizada: os gerentes utilizam a TI para solucionar problemas operacionais ou desafios específicos como, por exemplo, implantação de sistema de controle de estoque ou de serviço 24 horas para atendimento ao cliente. As aplicações de TI são, no geral, padronizadas e exigem mudanças mínimas no processo de negócio. Por isso, podem ser facilmente imitadas pelos concorrentes, não significando vantagens competitivas duradouras. O autor conclui que, neste nível, as aplicações de TI não são estratégicas.

- Integração interna: é uma extensão lógica do nível anterior. Envolve dois tipos ligação.

- Interconectividade técnica é a operação de diferentes sistemas e aplicações através de uma plataforma comum de TI.

- Interdependência nos negócios é a operação conjunta dos papéis e responsabilidades organizacionais nas diferentes funções.

- Reestruturação do processo de negócio: é necessário reestruturar a organização e estabelecer um novo processo de negócio. Os princípios organizacionais devem estar adequados à implantação das ferramentas de TI que não devem ser sobrepostas aos processos já existentes. 
- Estabelecimento da rede de negócios: os relacionamentos na rede garantem competências que permitirão aos compradores produzir produtos e serviços superiores. A rede está apoiada no uso da TI.

- Redefinição do escopo do negócio: os dois últimos níveis afetam diretamente o escopo do negócio e a forma de relacionamento entre os parceiros. Algumas tarefas podem ser eliminadas, outras reestruturadas e outras ainda ampliadas; alterando a distribuição dos lucros. Este nível de transformação também exige a reestruturação das atividades internas. Os processos internos, além de serem eficientes e eficazes, precisam estar coordenados com os processos externos.

Os três primeiros níveis tratam do papel da TI para transformação dos negócios dentro da organização. Os dois últimos estendem-se além dos limites da empresa, incorporando outras organizações. Os níveis um e dois são evolucionários porque exigem mudanças mínimas nos processos de negócios. Mas são fundamentais para a exploração do potencial estratégico dos três níveis superiores, estes sim revolucionários, já que exigem alterações profundas nas organizações.

Venkatraman (1994) conclui que os benefícios obtidos a partir do emprego da TI são marginais se apenas são superpostos às condições existentes. O objetivo não é a automatização dos processos de negócios, mas a sua reestruturação, obtendo melhores resultados para os clientes por meio de transações mais eficientes e precisas.

O caminho correto, portanto, não é decidir como utilizar a TI para melhorar os processos de negócio, mas entender no que o processo de negócio pode ser melhorado antes da implantação das tecnologias. Identificam-se, então, os processos que devem ser reformulados, priorizando os com maior potencial de retorno. Organizações que repensam e reformulam seus processos têm mais chances de sucesso (DAVENPORT; SHORT, 1990).

A reestruturação das empresas e processos pode criar novas oportunidades de negócios. Mas é a reestruturação da rede que permite o estabelecimento de novas fontes de vantagens competitivas e, portanto, a exploração de todo o potencial estratégico da TI (RAYPORT; SVIOKLA, 1995; HAMMER, 1990).

Mas, a definição dos projetos de TI que devem ser implantados e a avaliação dos recursos internos e competências necessárias para geri-los não é uma tarefa simples. Bowersox e Daugherty (1995), Nolan e McFarlan (2005), e Henderson e Venkatraman, (1993) discutiram o papel das tecnologias nas organizações com o objetivo de contribuir para definição e avaliação dos projetos de TI. 
Bowersox e Daugherty (1995) discutem a relação entre a TI e estratégia, metas, estrutura interna e estrutura externa da empresa. Henderson e Venkatraman, (1993) discutem a importância do alinhamento entre as aplicações de TI e o negócio para obtenção de vantagem competitiva. E, finalmente, Nolan e McFarlan (2005) discutem o papel das aplicações de TI - atuais e futuras - na estratégia das organizações. Estes estudos serão apresentados a seguir.

\subsection{Relação entre TI e estratégia, metas, estrutura interna e estrutura externa}

Bowersox e Daugherty (1995) discutem, em seu artigo "Logistics Paradigms: the impact of information technology", as relações existentes entre o posicionamento estratégico da empresa, suas metas, as estruturas organizacionais internas e externas ideais e o papel da TI. A estrutura da organização deve colaborar para que a empresa atinja suas metas de desempenho.

Estrutura organizacional é a alocação formal das regras de trabalho e dos mecanismos administrativos para controlar e integrar atividades, inclusive aquelas além dos limites formais da organização. Tem dois componentes críticos: linhas formais de autoridade e comunicação e as informações e dados que fluem nestas linhas (BOWERSOX; DAUGHERTY, 1995).

Estrutura interna são as regras e relacionamentos internos à empresa. Exige coordenação das tarefas funcionais para que a organização atinja a eficiência. Estrutura externa refere-se às relações existentes entre as empresas. Exige capacidade de comunicação sofisticada e estabelecimento de padrões entre as organizações (BOWERSOX; DAUGHERTY, 1995).

O Quadro 5 resume as principais conclusões dos autores. 


\section{Quadro 5}

Influência do posicionamento estratégico sobre as estruturas

\begin{tabular}{|c|c|c|c|}
\hline $\begin{array}{c}\text { Posicionamento } \\
\text { estratégico }\end{array}$ & Metas & \multicolumn{2}{|c|}{ Estrutura } \\
\hline Custo mínimo & Eficiência & $\begin{array}{c}\text { Maximização de resultados e } \\
\text { economias de escala. }\end{array}$ & $\begin{array}{c}\text { Transação orientada: compra } \\
\text { pelo menor preço, utiliza } \\
\text { muitos vendedores. }\end{array}$ \\
\hline $\begin{array}{c}\text { Valor adicionado } \\
\text { máximo }\end{array}$ & Eficácia & $\begin{array}{c}\text { Integração para atingir } \\
\text { qualidade/diferenciação. } \\
\text { e formalização. Especialização de } \\
\text { moderada a alta. }\end{array}$ & $\begin{array}{c}\text { Estabelecimento de } \\
\text { parcerias, limites maleáveis. }\end{array}$ \\
\hline $\begin{array}{c}\text { Melhoria no controle, } \\
\text { adaptação e } \\
\text { capacitação }\end{array}$ & Flexibilidade & $\begin{array}{c}\text { Maximizar flexibilidade local e } \\
\text { capacidade de resposta } \\
\text { Descentralização e baixa } \\
\text { formalização. Alta especialização }\end{array}$ & $\begin{array}{c}\text { Estabelecimento de amplas } \\
\text { alianças entre empresas: } \\
\text { customização ou adaptação. } \\
\text { Exige coordenação. }\end{array}$ \\
\hline
\end{tabular}

Fonte: adaptado de Bowersox e Daugherty (1995, p. 72).

Para Bowersox e Daugherty (1995), conforme o quadro acima, o objetivo da empresa pode ser classificado nos seguintes tipos:

(1) Se for o de reduzir custos e atrair um segmento de mercado sensível a preço, deve optar por uma estratégia de custo mínimo. A meta é atingir a máxima eficiência, ou seja, operar de forma a obter o melhor resultado possível, dados os recursos disponíveis. Eficiência pode ser avaliada por meio da lucratividade como porcentagem das vendas ou retorno sobre o investimento.

Estruturas centralizadas facilitam a coordenação dos esforços para controlar custos. A estratégia baseada em custo é adequada, sobretudo, para a elaboração de produtos ou serviços padronizados, com pouca especialização.

Bowersox e Daugherty (1995) afirmam que, historicamente, estas empresas têm alto nível de centralização interna e baixo nível de especialização. A estrutura centralizada facilita a direção comum e ajuda a coordenar os esforços para atingir o controle máximo dos custos.

A estratégia baseada em custo é adequada, sobretudo, para a elaboração de produtos ou serviços padronizados. A procura por padronização, por sua vez, minimiza ou mesmo elimina a necessidade de utilização de especialistas.

Externamente, estas empresas não estão voltadas para o estabelecimento de relacionamentos cooperativos de longo prazo. Geralmente utilizam uma ampla variedade de fornecedores para, por meio da competição, garantir o abastecimento e obter o menor preço. 
O papel da TI nesta estratégia é instrumento de suporte para que a empresa atinja a eficiência nos seus processos operacionais.

(2) Empresas cuja estratégia é adicionar o valor máximo aos seus produtos e processos precisam oferecer qualidade e diferenciação, mesmo que com custos superiores aos dos concorrentes. A meta destas empresas é atingir a eficácia, ou seja, desenvolver suas atividades melhor que os concorrentes. Eficácia pode ser avaliada em termos de crescimento relativo das vendas ou participação no mercado.

Geralmente, estas empresas adotam centralização e formalização moderadas. Certo nível de controle é necessário para auxiliar na integração das operações de produção e distribuição, embora possa ser menos rigoroso que nas estratégias de custo mínimo. Especialistas nos produtos e clientes são fundamentais nesta estratégia.

Quanto às suas estruturas externas, estas empresas estão voltadas para o estabelecimento de relações de longo prazo com parceiros selecionados. As parcerias estão baseadas na cooperação mútua e na partilha da informação porque diminuem a incerteza e o risco e melhoram a qualidade e produtividade.

O papel desempenhado pela TI nesta estratégia é fundamental. A integração das operações de produção e distribuição, assim como o estabelecimento de parcerias, são viabilizados por meio das aplicações de TI.

(3) Finalmente, Bowersox e Daugherty (1995) discutem a meta da empresa de atingir a flexibilidade. Flexibilidade é a capacidade de se adequar, com sucesso, às mudanças de condições e a explorar rapidamente novas oportunidades. Uma empresa flexível tem maior potencial para criar novos produtos e/ou serviços para seus clientes. Exige um posicionamento estratégico voltado para a melhoria no controle, adequação e capacitação.

Tais estratégias estão associadas às estruturas descentralizadas e baixo nível de formalização. Estruturas descentralizadas permitem que as unidades individuais sejam mais criativas e ágeis em suas decisões diante de novas situações. A baixa formalização, por sua vez, permite que as unidades individuais não estejam restritas a regras rígidas e ações predefinidas.

Estas empresas estão posicionadas para capitalizar novas oportunidades. Geralmente são mais especializadas que empresas com outro posicionamento estratégico. Especialização permite que a empresa atenda rapidamente às mudanças nos mercados e nas exigências dos clientes.

Quanto às estruturas externas, empresas com esta perspectiva buscam estabelecer relacionamentos cooperativos de longo prazo com seus parceiros. Estes relacionamentos são 
importantes para maximizar a capacidade de resposta, facilitando coordenação entre os parceiros e a customização e adequação dos produtos e serviços.

O estabelecimento de amplas alianças externas e a capacidade de se adequar a diferentes situações e parceiros apóia-se em intensa troca de informação e, portanto, no uso intensivo da TI. Assim, o papel da TI é central no desenvolvimento de estratégias baseadas na flexibilidade.

Bowersox e Daugherty (1995) analisam as relações entre o papel da TI e o posicionamento estratégico da empresa, suas metas, as estruturas organizacionais internas e externas ideais. A análise, portanto, é feita a partir da perspectiva interna das empresas. Outros estudos tratam a TI de uma perspectiva mais ampla, discutindo seu papel no processo de integração e na constituição de redes de empresas.

\subsection{Modelo de alinhamento estratégico}

Os conceitos de eficiência e eficácia ajudam a compreender o papel da TI nas organizações. Eficiência diz respeito a aspectos internos da gestão da TI e ao uso apropriado dos recursos, enquanto eficácia está relacionada aos resultados das aplicações de TI nas operações, nas estratégias do negócio, e na estrutura organizacional. Ser eficiente em TI significa utilizar a tecnologia adequadamente. Ser eficaz significa utilizar a tecnologia para tornar a empresa mais competitiva (LAURINDO, 2002).

Pesquisa realizada por Lai, Zhao e Wang (2007) apontou que sistemas de informação eficazes exigem que as tecnologias de informação estejam alinhadas com a estratégia global da empresa. No modelo de alinhamento estratégico proposto por Henderson e Venkatraman (1993), para que a TI seja eficaz é necessário haver alinhamento entre os fatores externos (estratégia) e os fatores internos (infra-estrutura).

O modelo define quatro principais perspectivas de alinhamento estratégico a partir das estratégias do negócio ou da TI.

- Execução da estratégia: a estratégia do negócio determina a infra-estrutura da organização e, conseqüentemente, a infra-estrutura de TI. A TI pode ser avaliada pelos critérios de desempenho de centros de custos ou por sistemas integrados de indicadores.

- Transformação tecnológica: a estratégia do negócio determina a estratégia de TI, que exige uma infra-estrutura de TI e processos adequados. A TI pode ser avaliada pelo que adiciona ao produto ou serviço final da empresa (por exemplo, aumento na receita, redução do risco, etc.). 
- Potencial competitivo: a adoção de uma estratégia da TI leva a uma nova estratégia nos negócios e, conseqüentemente, exige uma nova infra-estrutura. Tem capacidade de trazer impactos nos produtos e serviços, influenciando estratégias e relacionamentos no mercado. A avaliação de TI deve utilizar os mesmos critérios da perspectiva anterior.

- Nível de serviço: estratégia da TI resulta numa nova estrutura de TI e, conseqüentemente, uma nova estrutura de negócios. A avaliação da TI deve estar baseada nas medidas de satisfação do usuário final.

O quadro abaixo resume as principais características das perspectivas.

\section{Quadro 6 - Características das perspectivas de alinhamento estratégico}

\begin{tabular}{|c|c|c|c|c|}
\hline Perspectiva & Impulsionadora & $\begin{array}{c}\text { Papel da alta } \\
\text { direção da } \\
\text { empresa }\end{array}$ & $\begin{array}{c}\text { Papel da direção } \\
\text { de TI }\end{array}$ & $\begin{array}{c}\text { Critério de } \\
\text { desempenho }\end{array}$ \\
\hline $\begin{array}{c}\text { Execução da } \\
\text { estratégia }\end{array}$ & $\begin{array}{c}\text { Estratégia de } \\
\text { negócios }\end{array}$ & $\begin{array}{c}\text { Formulador de } \\
\text { estratégias }\end{array}$ & $\begin{array}{c}\text { Implantador de } \\
\text { estratégias }\end{array}$ & $\begin{array}{c}\text { Custos/centros de } \\
\text { serviço }\end{array}$ \\
\hline $\begin{array}{c}\text { Transformação } \\
\text { tecnológica }\end{array}$ & $\begin{array}{c}\text { Estratégia de } \\
\text { negócios }\end{array}$ & $\begin{array}{c}\text { Fornecedor de visão } \\
\text { de tecnologia }\end{array}$ & $\begin{array}{c}\text { Arquiteto de } \\
\text { tecnologia }\end{array}$ & $\begin{array}{c}\text { Liderança } \\
\text { tecnológica }\end{array}$ \\
\hline $\begin{array}{c}\text { Potencial } \\
\text { competitivo }\end{array}$ & Estratégia de TI & $\begin{array}{c}\text { Visionário de } \\
\text { negócios }\end{array}$ & Catalisador & $\begin{array}{c}\text { Liderança de } \\
\text { negócios }\end{array}$ \\
\hline Nível de serviço & Estratégia de TI & Priorizador & Liderança executiva & $\begin{array}{c}\text { Satisfação do } \\
\text { cliente }\end{array}$ \\
\hline
\end{tabular}

Fonte: Henderson e Venkatraman apud Laurindo et al. (2001).

Para Laurindo (2000, p. 5), de especial interesse são "transformação tecnológica" e "potencial competitivo". Isto por estarem "presentes nas estratégias de empresas que usam a tecnologia da informação para criar novas formas de relação com consumidores, parceiros, compradores e fornecedores". Na "transformação tecnológica" a estratégia de tecnologia viabiliza a estratégia de negócios (por exemplo, empresa tradicional que passa a atuar na Internet). No "potencial competitivo" a tecnologia permite a criação de novas estratégias de negócios (por exemplo, empresas virtuais).

Para Laurindo (2000, p. 4) a grande contribuição do modelo é "o fato de considerar que a estratégia da tecnologia da informação pode alterar a estratégia de negócios da empresa", invertendo o enfoque tradicional. E, embora concebido originalmente para analisar a estratégia da tecnologia em uma organização, "pode ser muito útil para o planejamento estratégico de relações entre empresas viabilizadas ou potencializadas pela tecnologia de informação" (LAURINDO, 2000, p. 5). 


\subsection{Modelo do Grid Estratégico}

O Grid Estratégico proposto por McFarlan (1984) analisa como a TI está relacionada à estratégia e a operação dos negócios da empresa. A TI tem um papel de maior ou menor importância conforme o tipo de operação e o setor de atuação das empresas. Em uma indústria tradicional, de modo geral, a TI desempenha o papel de suporte à operação, enquanto em um banco seu papel é estratégico.

De acordo com a importância que as aplicações de TI presentes e futuras têm para o negócio, o modelo classifica as empresas em quatro quadrantes: Suporte, Fábrica, Transição e Estratégico.

- Suporte: as aplicações de TI presentes e futuras têm pouca importância para a estratégia da empresa.

- Fábrica: as aplicações atuais de TI contribuem para o sucesso da empresa, mas não se planejam novas aplicações (companhias aéreas). Neste caso, a TI tem papel importante na estratégia da empresa.

- Transição: as aplicações de TI estão ganhando um maior destaque na estratégia da empresa (editoras, e-commerce).

- Estratégico: as aplicações de TI são fundamentais para a estratégia da empresa, afetando diretamente o desenvolvimento dos negócios (bancos, seguradoras, operadores logísticos).

Recentemente, Nolan e McFarlan (2005) redefiniram o Grid Estratégico: alteraram a denominação do quadrante "impacto presente" para "necessidade de TI confiável", e do quadrante "impacto futuro" para "necessidade de novas aplicações de TI" (figura 17).

\section{Figura 17 - Grid Estratégico}

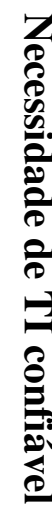

Baixo

Alto

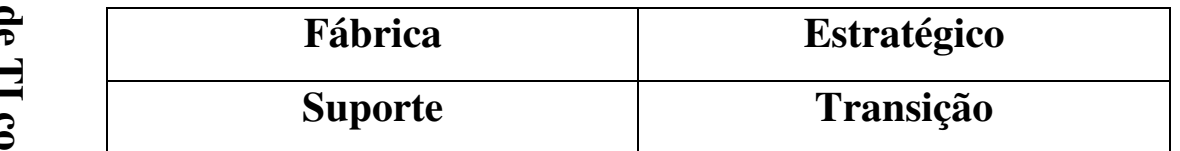

Alto

Baixo

Necessidade de novas aplicações de TI

Fonte: adaptado de Nolan e McFarlan (2005). 
Para Nolan e McFarlan (2005), as empresas classificadas nos quadrantes Transição e Estratégico adotam uma postura ofensiva no uso da TI, enquanto as empresas classificadas nos quadrantes Suporte e Fábrica têm uma postura defensiva.

\section{XXX}

A evolução da TI, nos anos 70, possibilitou uma maior eficiência administrativa. Nos anos 80, ampliou sua importância enquanto ferramenta estratégica. Atualmente, a TI é importante para a gestão da cadeia de suprimentos e na logística integrada. Neste capítulo, que encerra o referencial teórico, foram descritas a infra-estrutura TI e vários aplicativos sistemas de empresas, sistemas logísticos e práticas de gestão apoiadas na TI - e colocados alguns elementos que permitem analisar o papel estratégico da tecnologia.

A proposta dos cinco capítulos que compõem o referencial teórico era fornecer os elementos para fundamentar a pesquisa de campo, identificando questões relevantes que deverão ser abordadas na pesquisa empírica (BONOMA, 1985). Foram apresentados diversos conceitos: estratégia, redes de empresa, cadeia de suprimentos, logística, operadores logísticos e tecnologias de informação.

A segunda parte do estudo refere-se à pesquisa empírica. O capítulo 6, a seguir, apresenta a metodologia de pesquisa - estudo de casos - e sua aplicação aos objetivos do estudo. No capítulo 7 serão analisados os cinco casos estudados e confrontados com as questões de pesquisa. Finalmente, na conclusão, serão apresentados os principais resultados. 


\section{CAPÍTULO 6 METODOLOGIA}

\subsection{Metodologia de pesquisa}

Metodologia de pesquisa é um conjunto de atividades sistemáticas visando atingir um determinado objetivo (SEKARAN, 1984; FACHIN, 2001).

As pesquisas podem ser classificadas em: exploratória, aplicada ou teórica. A pesquisa exploratória ou descritiva permite definir melhor um problema, compreender seus aspectos, descrever comportamentos, e definir e classificar variáveis (MATTAR, 1996, MIGUEL, 2007).

A pesquisa exploratória é adequada quando o objetivo é compreender um tema ainda pouco estudado ou quando a teoria é demasiadamente ampla e o pesquisador está interessado em aspectos específicos. Isto porque, este tipo de pesquisa permite a familiarização ou o estabelecimento de uma nova visão a respeito de um fenômeno: o pesquisador pode formular um problema de pesquisa mais preciso ou criar novas hipóteses e, a partir daí, fornecer as bases para um modelo teórico (TRIVIÑOS, 1987).

Os métodos de pesquisa podem ser indutivos ou dedutivos. Os dedutivos buscam a solução de um problema a partir de uma lei ou teoria. Os indutivos a partir de constatações particulares que podem evoluir para generalizações.

Uma pesquisa pode ser quantitativa ou qualitativa. A abordagem qualitativa enfatiza a perspectiva do indivíduo que esta sendo estudado e a interpretação das informações obtidas é de grande importância. O pesquisador procurar captar os aspectos relevantes para os entrevistados e o contexto onde ocorre o fenômeno. A pesquisa qualitativa quer entender os processos dos fenômenos (MATTAR, 1994).

$\mathrm{Na}$ pesquisa qualitativa, os dados podem ser primários ou secundários. Dados primários são coletados por meio de observação participativa, entrevistas não estruturadas ou semi-estruturadas, e que tem o propósito de atender as necessidades específicas da pesquisa. Dados secundários são coletados por meio de exame de documentos, disponíveis para consulta em publicações ou na internet (MATTAR, 1997).

$\mathrm{Na}$ entrevista semi-estruturada parte-se de questionamentos básicos de interesse para a pesquisa. À medida que o entrevistado vai respondendo as perguntas colocadas pelo pesquisador, podem surgir novos questionamentos. "Desta maneira o informante, seguindo 
espontaneamente a linha de seu pensamento e de suas experiências dentro do foco principal colocado pelo investigador, começa a participar na elaboração do conteúdo da pesquisa" (TRIVIÑOS, 1987, p. 49).

Finalmente, quanto a abordagem metodológica, Yin (1994) classifica as pesquisas em experimental, de avaliação, pesquisa-ação e estudo de caso. A definição da abordagem mais adequada exige a observação dos conceitos envolvidos e os objetivos da pesquisa, a validade da construção interna e externa, e a confiabilidade. Assim, é importante definir, em primeiro lugar, o problema a ser pesquisado para, depois, encontrar o procedimento de pesquisa adequado (YIN, 1994).

Assim, um dos principais fatores a ser considerado na definição da abordagem metodológica é a questão (ou questões) que se pretende responder. Segundo Yin (1994), após revisão bibliográfica, o pesquisador desenvolve as questões de pesquisa e, a partir delas, define a abordagem metodológica mais adequada. O estudo de caso é adequado para responder perguntas do tipo como e por que (MIGUEL, 2007).

\subsection{Tipo de pesquisa: estudo de casos}

O estudo de caso é uma pesquisa empírica que tem o objetivo de investigar os fenômenos em seu contexto real. Coleta e registra informações sobre um ou vários objetos (organizações, empresas, comunidades, etc.) e pode ser utilizado para descrever, explicar, avaliar e explorar fenômenos atuais que não estão sob o controle do investigador (YIN, 1994).

O estudo de caso é adequado, sobretudo, para aprofundar o conhecimento sobre um objeto ainda pouco estudado. Por meio do estudo de caso é possível melhorar a compreensão sobre dado assunto, permitindo o levantar hipóteses ou desenvolver novas teorias (MIGUEL, 2007).

O método propõe a realização de uma análise profunda visando obter conhecimento detalhado. A pesquisa pode estar restrita a um único caso ou a múltiplos estudos de caso. A seleção de um único caso é válida quando ele apresenta particularidades que o tornam raro ou revelador de algum fenômeno desconhecido. Ou, ainda, quando é suficiente para confirmar, contestar ou compreender uma teoria (YIN, 1994).

Os estudos de casos múltiplos são considerados mais convincentes e robustos que os individuais. Os diversos casos devem ser analisados individualmente e de forma cruzada. A análise individual permite consolidar as informações coletadas. A análise entre os casos, por 
sua vez, identificar semelhanças e diferenças. Assim, pode-se confirmar ou refutar as proposições iniciais e formular novas proposições (EISENHARDT, 1989).

Um aspecto crítico nos estudos múltiplos diz respeito ao número de casos que devem ser realizados. Para Eisenhardt (1989), para validar a pesquisa devem ser realizados pelo menos quatro estudo de casos, já que um número inferior não permite a geração de teorias.

Yin (1994) recomenda extremo cuidado ao planejar e realizar estudos de caso. Isto porque, muitas vezes, aceitam-se evidências equivocadas ou visões tendenciosas que influenciam as conclusões. A falta de rigor é uma das principais críticas a este método de pesquisa.

Outra crítica é a impossibilidade de, a partir da análise de um ou de poucos casos, estabelecer generalizações científicas. Para Yin (1994), fatos científicos raramente baseiam-se em experimentos únicos. Decorrem, no geral, de um conjunto de múltiplos experimentos onde o fenômeno é repetido sob diferentes condições.

Apesar de reconhecer a validade das críticas, Yin (1994) argumenta que o método de estudo de caso permanece válido porque:

- É útil para identificar características e ligações entre os fenômenos e nas construções teóricas (modelos). Estudos de caso múltiplos ou replicações de um único estudo de caso com outras amostras oferecem indicações do grau de generalização possível.

- Busca compreender, na maior parte das vezes, um conjunto de decisões: por que foram tomados, formas de implantação e quais os resultados alcançados.

- É possível verificar sua validade e confiabilidade por meio de estudos estatísticos e experimentais que validarão ou não as conclusões.

\subsection{Componentes do estudo de caso}

Para Yin (1994), o estudo de caso deve conter cinco componentes que sustentarão e guiarão o pesquisador em seu trabalho:

- Questões de pesquisa: são o ponto de partida e ajudam o pesquisador a manter-se focado em seu objeto. Estudos de caso são adequados para responder questões do tipo como e por quê.

- Proposições: devem refletir as questões e indicar onde procurar evidências relevantes. Elas expressam o entendimento prévio do pesquisador sobre o assunto. Bonoma (1985) ressalta a importância da construção de um referencial teórico para a construção das proposições. O referencial teórico fundamenta a realização do estudo de caso. 
- Unidade de análise: deve atender aos objetivos da pesquisa e as questões de estudo. A unidade de análise pode ser uma empresa, processo, indivíduo ou vários agentes.

- Ligação dos dados à proposição e critérios para a interpretação dos dados: estes dois componentes constituem a análise do Estudo de Caso. O primeiro relaciona as informações obtidas na pesquisa às proposições estabelecidas. $\mathrm{O}$ segundo busca responder às questões iniciais.

Yin (1994) recomenda, ainda, a formulação de um protocolo de pesquisa que garanta a homogeneidade nos procedimentos. O protocolo deve conter as etapas, os instrumentos e as regras gerais que devem ser seguidas na aplicação e no uso dos instrumentos. A função do protocolo é aumentar a confiabilidade da pesquisa, direcionando o pesquisador nas atividades do estudo e estabelecendo as regras gerais que serão seguidas em campo.

Finalmente, a preparação final do investigador para a coleta de dados é a condução de um estudo piloto ou exploratório. O estudo piloto, segundo Yin (1994), é fundamental para identificar as questões que deverão ser tratadas, pois permite um entendimento mais geral do objeto de pesquisa. O pesquisador pode testar seus procedimentos e efetuar, se necessário, ajustes para aumentar a probabilidade de sucesso na condução do estudo de caso.

A figura abaixo indica os diversos componentes do estudo de caso e como estão relacionados. 
Figura 18 - Estudo de casos

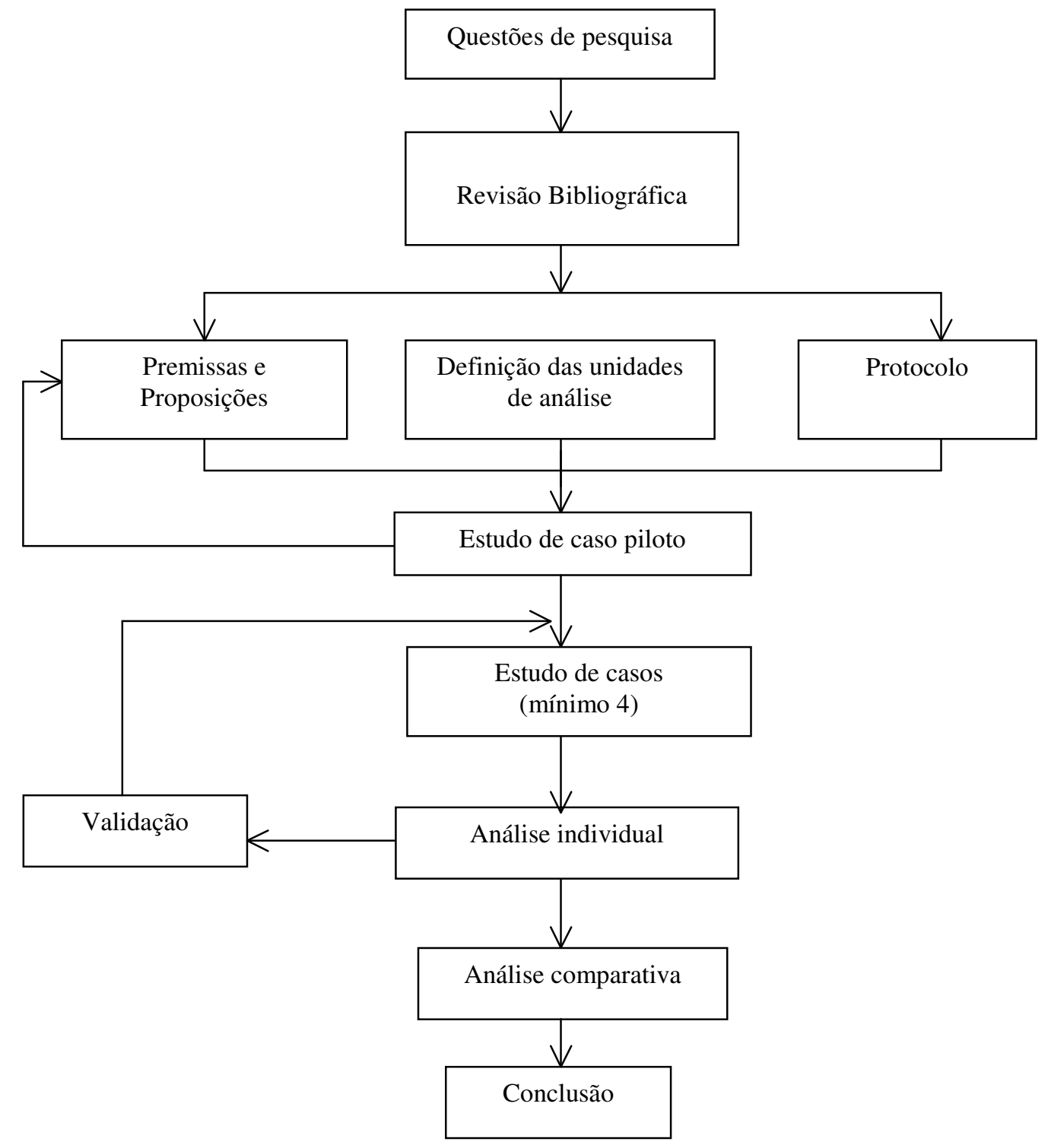

Fonte: elaborado pelo autor (2008).

\subsection{Desenvolvimento do estudo de caso}

No caso específico das pesquisas na área de TI, o método do estudo de caso vem sendo bastante utilizado na avaliação de suas aplicações. Grande parte dos estudos na área são empíricos (68\%) e, destes, 31\% são estudos de caso (CLAVER; GONZALEZ; LOPES, 2000).

A realização de estudos de caso nesta área é adequada porque: 
- O objeto - a TI - está em constante mutação (HARTLEY, 1994),

- Permite identificar o estágio atual de desenvolvimento da tecnologia e construir teorias a partir das práticas verificadas (BENBASAT; GOLDSTEIN, 1987),

- O objetivo é investigar as aplicações e não os aspectos técnicos (BENBASAT; GOLDSTEIN, 1987),

- Existem, ainda, poucos estudos e é freqüente o surgimento de novos tópicos que devem ser abordados (BENBASAT; GOLDSTEIN, 1987).

Os objetivos e, conseqüentemente, as questões de pesquisa desta tese enquadram-se nas características descritas acima indicando, portanto, que o método do estudo de caso é uma abordagem adequada para a condução do presente trabalho.

Assim, a pesquisa será exploratória, utilizando o método indutivo e, como procedimento, a realização de estudo de casos múltiplos. A abordagem adotada será a qualitativa e os dados serão coletados através de entrevistas semi-estruturadas e outras eventuais fontes (CLAVER; GONZALEZ; LOPES, 2000; YIN, 1994).

De acordo com o roteiro proposto por Yin (1994), serão destacados abaixo os componentes do estudo de casos: questões de pesquisa, proposições e unidades de análise. Após a realização do estudo de caso, serão elaborados os componentes de análise: ligação dos dados obtidos à proposição e os critérios para a interpretação.

\subsubsection{Questões de pesquisa}

Duas questões são fundamentais para o desenvolvimento do estudo.

1. Como a TI é utilizada pelos operadores no processo logístico?

2. Como a TI contribui para o estabelecimento das redes de valor?

\subsubsection{Premissas e proposições}

Para responder a primeira questão de pesquisa, partiu-se de duas premissas (premissas 1.1 e 1.2). As premissas foram estabelecidas por meio do levantamento bibliográfico e fundamentaram o trabalho.

Premissa 1 - Para compreender como a TI é utilizada pelos operadores no processo logístico é preciso: 
Premissa 1.1 - Identificar o uso da TI em cada uma das cinco áreas do trabalho logístico e, dentro de cada área, nas diversas atividades (BOWERSOX; CLOSS, 2001; LAUDON; LAUDON, 2004).

- Os operadores logísticos estabelecem os elos entre os ciclos de distribuição, de apoio à manufatura e de suprimentos por meio do processo logístico. O processo logístico, por sua vez, envolve a execução e gerenciamento dos fluxos de materiais, produtos e informações. Portanto, para estudar o processo logístico é necessário mapear os fluxos de materiais, produtos e informação entre os agentes.

- Os fluxos são executados e gerenciados por meio do desenvolvimento do trabalho logístico. O trabalho logístico envolve cinco áreas projeto de rede; transporte; controle de estoque; armazenagem, manuseio de materiais e embalagens; e informação. E, cada área envolve uma série de atividades.

\section{Premissa 1.2 - Analisar o papel da TI no apoio às atividades desenvolvidas.}

As atividades desenvolvidas, a forma como são combinadas e as tecnologias utilizadas são determinadas pelo posicionamento estratégico do operador. E o posicionamento estratégico pode ser compreendido por meio de duas perspectivas: (1) interna e (2) do mercado atendido (BERGLUND, 1997).

1. Na perspectiva interna, os operadores são vistos a partir de seu próprio processo de produção. Portanto, trata-se de analisar o papel da TI no desenvolvimento do processo logístico do operador.

- O papel da TI é central para os operadores cuja meta é a flexibilidade (capacidade de se adequar às mudanças de condições e de explorar novas oportunidades) e naqueles cuja meta é atingir a eficácia (ampliar a competitividade) (BOWERSOX; DAUGHERTY, 1995). Eficácia está relacionada aos resultados das aplicações de TI nas operações, nas estratégias do negócio, e na estrutura organizacional (NOLAN; MCFARLAN, 2005; HENDERSON; VENKATRAMAN, 1993).

- Para que a TI contribua para a competitividade do processo logístico é necessário haver alinhamento entre os fatores externos (estratégia) e os fatores internos (infra-estrutura) da organização (HENDERSON; VENKATRAMAN, 1993). 
- E o papel das aplicações de TI - presentes e futuras - no posicionamento estratégico da empresa pode ser compreendido por meio do Grid Estratégico (NOLAN; MCFARLAN, 2005).

2. Na perspectiva do mercado atendido os operadores são vistos a partir de seus clientes. Portanto, trata-se de analisar o papel da TI no atendimento das necessidades dos clientes. Os clientes apresentam diferentes:

- Exigências logísticas determinadas pela complexidade logística. Quanto maior a complexidade logística, maior a necessidade de aplicações de TI (BOWERSOX; CLOSS, 2001).

- Políticas de produção. Deve haver articulação e coerência entre o trabalho logístico e a política de produção dos clientes. Nos sistemas push (empurrar) a produção é definida por previsão, ou seja, está baseada nas expectativas de venda. Já nos sistema pull (puxar), a produção atende aos pedidos efetivamente realizados, operando em tempo real e exigindo, portanto, processos logísticos mais ágeis. Partilha de dados, colaboração entre os agentes e aplicativos que permitam aos produtores e varejistas o planejamento conjunto do suprimento e da produção estão nos fundamentos destes sistemas de produção (CHANDRASCHEKAR; SCHARY, 1999).

A figura 19 retrata em um fluxograma as premissas e os autores analisados para responder a primeira questão de pesquisa. 
Figura 19 - Premissas e autores analisados (questão 1)

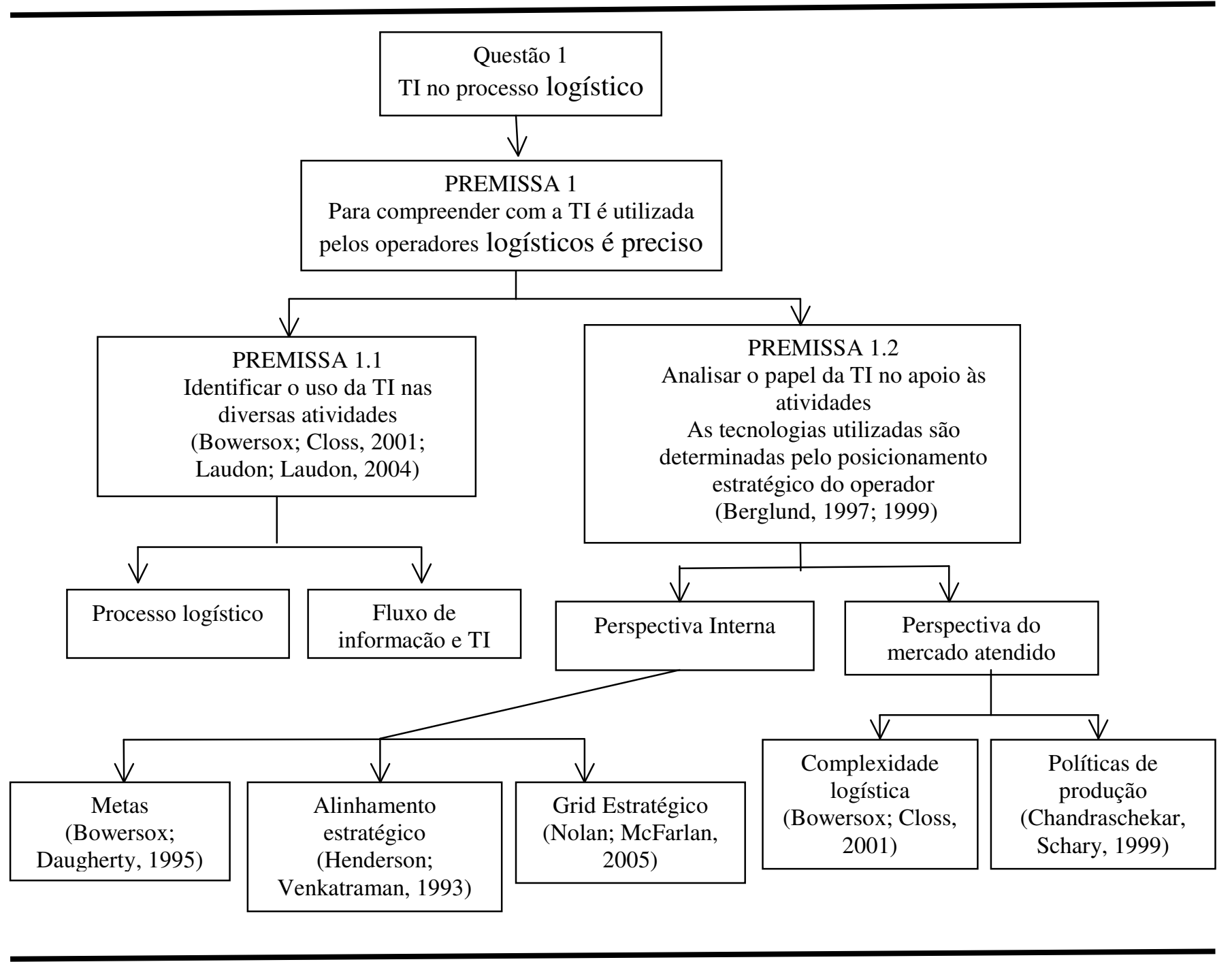

Fonte: elaborado pelo autor (2008).

Considerando estas premissas como ponto de partida, as proposições a seguir foram elaboradas a partir das questões de pesquisa e do levantamento bibliográfico. Elas pretendem relacionar as questões investigadas a outras pesquisas já realizadas, oferecendo subsídios para a análise dos estudos de caso.

Proposição 1 - Para que o operador logístico torne-se flexível e atinja a eficácia é necessário o desenvolvimento de aplicativos customizados que atendam suas particularidades e garantam alinhamento entre os fatores externos e internos (BOWERSOX; DAUGHERTY, 1995; HENDERSON; VENKATRAMAN, 1993) 
Proposição 2 - A complexidade logística e, portanto, as ferramentas de TI, são determinadas pelas características do setor.

Proposição 3 - Se a produção está baseada na expectativa de vendas (push), o papel desempenhado pela TI é menos importante do que quando está baseada nas vendas efetivamente realizadas (pull).

A segunda questão de pesquisa - como a TI contribui para o estabelecimento das redes de valor - foi fundamentada nas proposições 4.1 e 4.2 .

Proposição 4 - a TI está na base da gestão integrada da logística. E a gestão integrada da logística está na base do estabelecimento das redes de valor.

\section{Proposição 4.1: A TI está na base da gestão integrada da logística}

Gestão integrada da logística pressupõe integração e coordenação dos fluxos e estoques de materiais, produtos e informação e o estabelecimento de parcerias entre diferentes agentes.

- A integração é um processo complexo que deve ser implantando de forma gradativa. Nos seus estágios mais avançados ocorre o compartilhamento total da informação, permuta de tecnologias, estabelecimento de parcerias de longo prazo e foco na estratégia (STEVENS, 1989).

- A coordenação garante o controle das atividades e a execução conjunta dos processos empresariais por uma ou mais empresas (TURBAN; RAINER; POTTER, 2003). Exige o estabelecimento de padrões comuns com relação às tecnologias, sistemas de codificação de materiais, e práticas de automação e gestão entre as empresas (CHANDRASHEKAR; SCHARY, 1999).

- As parcerias baseiam-se no intercâmbio de informações, aglutinação de competências e exploração de oportunidades tecnológicas e de mercado promissoras. Podem ser motivadas por (BRITTO, 2002):

- Integração conjunta das atividades visando atingir estágio mais avançado na cadeia de produção e comercialização de bens; 
- Configuração aditiva que articula duas ou mais empresas de determinada indústria visando aumento da escala, ampliação do mercado interno e enfraquecimento da concorrência;

- Configuração complementar que integra duas ou mais empresas visando ampliar competências complementares e, portanto, melhorar competitividade.

\section{Proposição 4.2: A gestão integrada da logística está na base das redes de valor.}

Para que uma rede possa constituir uma rede de valor, os fluxos e estoques de materiais, produtos, serviços e informação devem ser administrados como um processo contínuo entre as empresas, ou seja, os agentes operam de forma colaborativa e ocorre o compartilhamento total das informações. Parcerias fortes e uso intensivo de tecnologia fornecem a base para o estabelecimento das redes de valor (BOVET; MARTHA, 2001).

A figura 20 retrata em um fluxograma as proposições 4.1 e 4.2 e os autores analisados para responder a segunda questão de pesquisa.

\section{Figura 20 - Proposições e autores analisados (questão 2)}

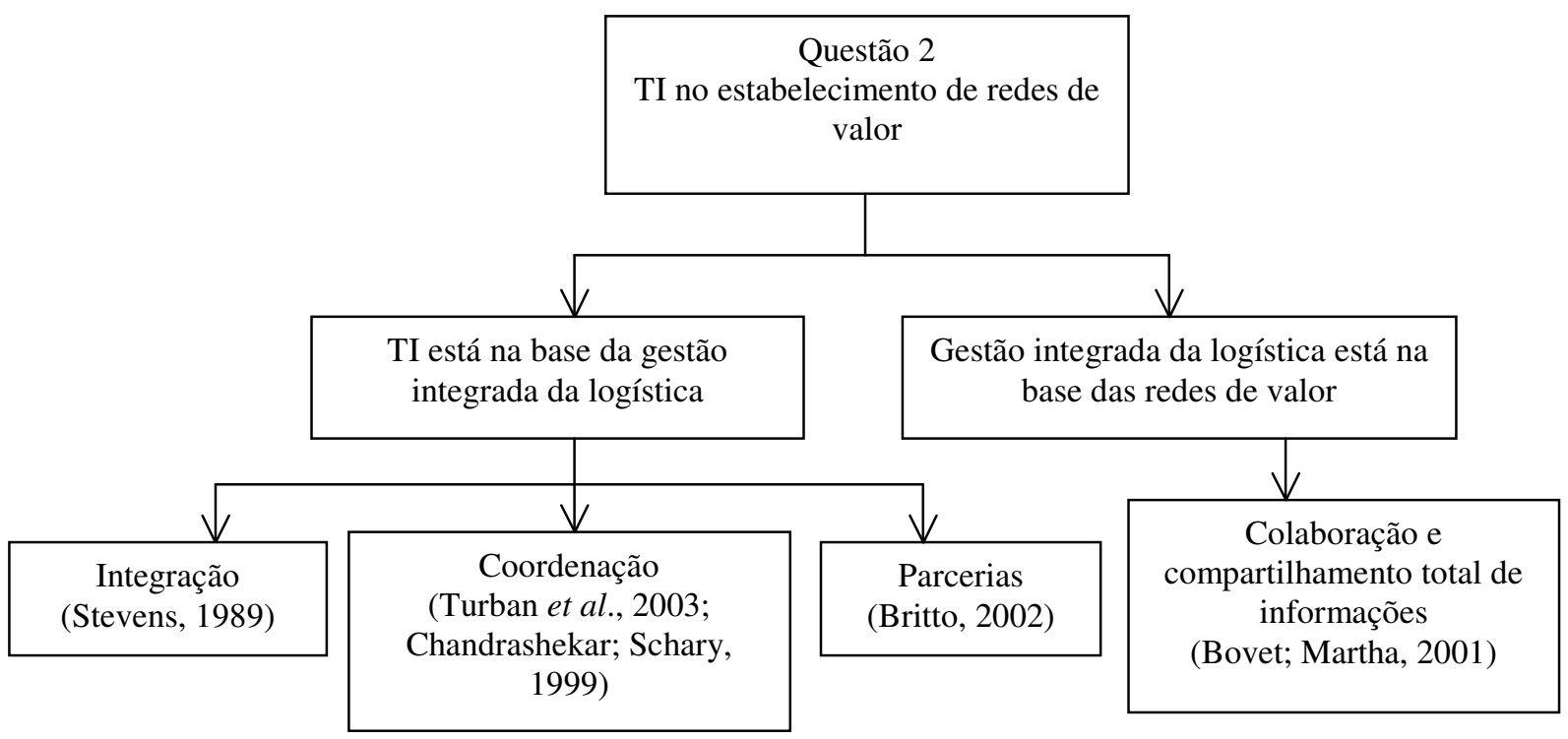

Fonte: elaborado pelo autor (2008). 


\subsubsection{Unidades de análise: operadores logísticos}

A pesquisa foi realizada com cinco operadores logísticos com atuação no mercado brasileiro selecionados de forma intencional. Quando se utiliza uma amostragem intencional, é importante escolher casos que atendam aos objetivos da pesquisa e permitam confirmar ou refutar as proposições (SELLTIZ, 1974).

Antes da realização do estudo de casos propriamente dito, foi feito um estudo piloto com um dos operadores logísticos (Operador logístico 1 - OL 1). OL 1 é um operador logístico internacional, que atua enquanto prestador de serviços de importação e exportação, e foi selecionado para o estudo pela facilidade de acesso do pesquisador ao seu diretor operacional.

A primeira entrevista foi realizada no início de 2006, antes ainda da conclusão do referencial teórico, e resultou em um artigo publicado nos anais da Third International Conference on Production Research Americas' Region 2006 (Apêndice 1).

O estudo piloto permitiu uma primeira aproximação com o objeto a ser estudado, testar os procedimentos de pesquisa e efetuar os ajustes necessários para uma melhor condução dos demais estudos de casos. Após a conclusão do referencial teórico e definido o formato final (Apêndice 2), foi realizada nova entrevista com OL 1 em setembro de 2007.

Os demais operadores logísticos foram selecionados de modo a atender os objetivos da pesquisa e verificar as proposições apresentadas. Assim, foram selecionados operadores com diferentes posicionamentos estratégicos, operando em diferentes setores, e de modo a cobrir os três ciclos do processo logístico: ciclo de distribuição, de apoio à manufatura e de distribuição. São eles:

- Operador logístico 2 (OL 2): presta serviço em distribuição e operações logísticas exclusivamente para uma rede fast-food.

- Operador logístico 3 (OL 3): atua na armazenagem, e na gestão do transporte e da cadeia de suprimentos especialmente nos setores automotivo, eletroeletrônico e de consumo.

- Operador logístico 4 (OL 4): atua na armazenagem, e na gestão do transporte e da cadeia de suprimentos em empresas de todos os tamanhos e com necessidades variadas. Entre seus clientes estão empresas do setor automotivo, químico e industrial, consumo e varejo, saúde e tecnologia.

- Operador logístico 5 (OL 5): atua exclusivamente na logística interna de empresas de vários setores. 


\subsubsection{Protocolo de pesquisa}

O protocolo de pesquisa apresenta os procedimentos, os instrumentos e as regras gerais que foram seguidas pelo pesquisador na aplicação das entrevistas e na elaboração dos relatórios.

\subsubsection{Coleta e tratamento dos dados}

A pesquisa apoiou-se em duas fontes de dados: primários e secundários.

- Os dados secundários foram obtidos em visita aos sites das empresas na internet e em publicações especializadas em logística.

- Os dados primários foram obtidos por meio de entrevistas semi-estruturadas com executivos da área de TI das empresas estudadas.

Antes da aplicação de cada entrevista foram:

- Visitados os sites das empresas na internet, além de outras fontes de dados, de modo a captar o máximo de informações possíveis sobre o operador logístico.

- Enviados ao entrevistado o roteiro da entrevista para que pudesse tomar conhecimento dos objetivos da pesquisa e das questões gerais.

As entrevistas ocorreram ao longo dos meses de outubro e novembro de $2007 \mathrm{com}$ executivos da área de TI dos operadores logísticos. Foram realizadas no local de funcionamento das empresas, em data e horário previamente agendados. As entrevistas não tiveram tempo de duração pré-estabelecido e demoraram, em média, cerca de duas horas e meia.

O roteiro de entrevista foi composto de perguntas abertas e foi dada total liberdade para o entrevistado discorrer sobre os aspectos que considerava mais importantes. Ao final da entrevista, o roteiro era consultado e as eventuais lacunas preenchidas.

Todos os entrevistados concordaram com a gravação das entrevistas, garantindo maior fidedignidade na coleta das informações. Posteriormente as entrevistas foram transcritas pelo pesquisador. Para cada estudo de caso foi elaborado um relatório, com estruturas semelhantes, onde se procurou apresentar as evidências de forma neutra, apenas relatando o que foi coletado pelo pesquisador nas entrevistas.

Algumas dúvidas, ou mesmo novos questionamentos, que surgiram no momento da elaboração do relatório foram solucionados contatando, por telefone ou e-mail, os executivos entrevistados. 


\subsubsection{Estrutura do relatório}

Visando facilitar a coleta dos dados e reduzir a possibilidade de eventuais lacunas, a estrutura dos estudos de casos foi definida antes da realização das entrevistas e baseou-se nas proposições. O relatório final do estudo de caso dever conter elementos que permitam ao pesquisador verificar a validade de suas proposições.

Cada estudo de caso deve abordar os seguintes aspectos:

- Caracterização do operador logístico

- Mapeamento do processo logístico, identificando e analisando:

- Os agentes, suas posições, e os elos existentes entre eles

- O processo logístico e sua dinâmica

- Identificação dos fluxos de informação e das tecnologias adotadas para apoiar o processo logístico

- Identificação dos níveis de integração existentes entre os agentes

\subsubsection{Etapas de validação}

Após a redação, os estudos de caso foram enviados para os entrevistados para que fossem revisados. Este procedimento permite corroborar os fatos e as evidências apresentados e aumentar a validade do estudo de caso. Além disto, possibilita o surgimento de evidências adicionais, já que os entrevistados podem lembrar de elementos não citados na coleta inicial.

Não houve discordância dos entrevistados quanto ao conteúdo dos relatórios e, eventualmente, foram acrescentados novos elementos.

\subsubsection{Ligação dos dados à proposição e critérios para a interpretação dos dados}

Após a validação dos estudos de casos pelos entrevistados, as informações obtidas foram relacionadas às proposições e procurou-se responder as questões de pesquisa para cada caso individualmente.

Finalmente, foi realizada a análise entre os casos estudados, identificando semelhanças e diferenças, e confirmando ou refutando as proposições iniciais. Diante das evidências observadas, foi proposta na conclusão da tese uma nova tipologia que permite descrever melhor a realidade encontrada, ainda que limitada ao universo pesquisado. 


\subsubsection{Limitações do Método}

Pelas limitações inerentes ao método do estudo de casos, este trabalho não se propõe a realizar generalizações conclusivas sobre o assunto. Esta impossibilidade existe não só pelo fato de se trabalhar com uma amostra reduzida, mas também por não ser possível isolar o objeto estudado do meio onde opera. Assim, o principal objetivo é explorar e descrever os casos pesquisados e verificar de que forma permitem responder as perguntas da pesquisa, procurando manter a objetividade e a isenção na descrição e análise dos elementos. 


\section{CAPÍTULO 7 INDÚSTRIA LOGÍSTICA E ESTUDO DE CASOS}

A primeira parte do capítulo analisa, brevemente, a indústria logística. O objetivo é compreender melhor o ambiente aonde a pesquisa irá se desenvolver. A identificação e análise de característica e tendências do setor permitem analisar, com maior critério, as ações e estratégias dos operadores logísticos (PORTER, 2001).

A segunda parte apresenta os cinco casos estudados. $\mathrm{O}$ estudo piloto foi realizado com o operador logístico 1 (OL 1) e permitiu aperfeiçoar o protocolo de pesquisa utilizado para os outros casos estudados. O resultado da primeira entrevista é um artigo disponibilizado no Apêndice 1 da tese. O estudo de caso de OL 1 apresentado aqui resultou da segunda entrevista realizada com o operador e obedece ao formato geral dos demais casos.

Finalmente, é realizada uma análise cruzada procurando identificar semelhanças e diferenças entre os casos.

\section{Indústria logística}

Pode-se observar em todo o mundo uma forte tendência à terceirização das atividades logística e, como consequiência, um rápido crescimento do setor de prestação de serviços nesta área. Além da terceirização, outros fatores contribuem para ao crescimento do setor logístico: importância do serviço ao cliente, novos padrões de relacionamento entre os agentes e as possibilidades oferecidas pelo desenvolvimento das tecnologias. A crescente complexidade das cadeias de suprimentos vem aumentando a necessidade de investimento em logística e, consequentemente, as oportunidades para os prestadores de serviços logísticos (FLEURY; RIBEIRO, 2001).

Um número cada vez maior de prestadores de serviços vem ocupando estes mercados. Nos EUA existiam, em 2003, aproximadamente 5000 empresas no setor logístico. Em 2004 as receitas dos prestadores logísticos ultrapassaram US\$ 89 bilhões (ASHENBAUM; MALTZ; RABINOVITCH; 2005). Estima-se que 50 a $60 \%$ dos custos logísticos totais são terceirizáveis, indicando o potencial de penetração dos operadores (CHOW; GRITTA; 2002). Na Europa, o mercado logístico que era de cerca de EU\$ 51,4 bilhões em 2001, foi para EU\$ 70 bilhões em 2005 e $51 \%$ dos gastos logísticos foram terceirizados (ALLEN, 2003). 
No Brasil, pesquisa da Revista Tecnologística em 2003 apontou crescimento expressivo no número de agentes e no faturamento do setor: em 1998 havia 35 empresas com faturamento total de R \$1 bilhão. Em 2002, eram 124 empresas com faturamento total de R \$ 4,7 bilhões.

A indústria logística brasileira despontou com a abertura comercial em 1990, e ganhou novo impulso em 1997 com a chegada dos operadores trazidos pelas multinacionais (LIMA, 2004). Parte deles vem se estabelecendo no país associando-se as empresas nacionais (FLEURY; RIBEIRO, 2001a). O mercado está sendo ocupado também por prestadores de serviços brasileiros já estabelecidos e por novas empresas nacionais que estão surgindo. $\mathrm{O}$ Brasil, como o resto do mundo, tem ainda grande potencial de crescimento.

Fleury e Ribeiro (2001a) analisaram dados globais da indústria logística brasileira e procuraram entender sua dinâmica. O estudo analisou as atividades oferecidas pelos prestadores frente às demandas do mercado, setores atendidos e as tecnologias de informação utilizadas. Os autores utilizam, para análise dos operadores, dados fornecidos pela revista Tecnologística de junho de 2003. Para os dados relativos à demanda de serviços logísticos, os autores pesquisaram 93 grandes empresas brasileiras atuando em 14 setores.

De um elenco de quinze serviços oferecidos pelos operadores pesquisados, nove são disponibilizados por $90 \%$ deles, destacando-se as atividades de armazenagem, controle de estoque, distribuição e coordenação oferecidas por quase todos os provedores. As atividades menos ofertadas, mas que vem apresentando o maior crescimento, são as mais sofisticadas: milk-run, JIT, gerenciamento intermodal, logística reversa e montagem de kits. As atividades que apresentam maior crescimento são as mais sofisticadas, como logística reversa, serviços JIT, montagem de kits e gerenciamento intermodal.

Fleury e Ribeiro, (2001a) concluíram haver um descompasso entre a oferta e a demanda dos serviços logísticos. Pelo lado da oferta, os prestadores buscam ampliar a variedade de serviços oferecidos. Pelo lado da demanda, os embarcadores enfatizam preço, experiência anterior e qualidade técnica da mão de obra do prestador.

Os clientes desejam provedores focados e eficientes e não consideraram a variedade dos serviços oferecidos o fator mais importante. Para atender este mercado cada vez mais exigente, os prestadores de serviço deveriam estar buscando uma maior especialização e atendimento customizado. Fleury e Ribeiro (2001a) concluem que pouca atenção vem sendo dada por estes agentes a estas questões.

Com relação aos setores atendidos, Fleury e Ribeiro (2001a) utilizaram diversos critérios de classificação. Os setores mais importantes e que devem ser analisados com maior 
cuidado são: químico e petroquímico, automotivo, higiene e limpeza, farmacêutico, cosméticos, eletroeletrônico, alimentício, e siderurgia e metalurgia.

Finalmente, com relação à adoção de tecnologias, os autores constataram que somente os sistemas de processamento de pedidos e os ERPs foram adotados de forma ampla pelas empresas: 96 e 80\% respectivamente. O uso das demais ferramentas de TI ainda é bastante insatisfatório. Por exemplo, no transporte, o rastreamento de veículos foi adotado por cerca de $60 \%$ das empresas, roteirização e auditoria dos fretes por pouco mais de 50\%. Nos armazéns, as tecnologias mais utilizadas foram radiofreqüência (44\%), separação e picking (54\%), código de barras (56\%) e endereçamento (63\%). A adoção das tecnologias é, portanto, baixa frente a sua importância para o aumento da produtividade e redução dos custos.

Mas a indústria logística é extremamente complexa e composta por um grande número de prestadores de serviços com os mais variados graus de sofisticação. São considerados prestadores desde simples especialistas operacionais até integradores logísticos.

Em outro estudo, Fleury e Ribeiro (2001b) estudaram somente os prestadores de serviços que atuavam como operadores logísticos. Os autores definem operadores logísticos como os prestadores de serviços capazes de executar e gerenciar, de forma integrada, no mínimo três atividades: armazenagem, transporte e controle de estoque.

Fleury e Ribeiro (2001b) selecionaram oito operadores brasileiros entre os maiores e mais conhecidos do mercado. Embora a amostra pesquisada seja reduzida, ela indica as características dos agentes que atuam nos níveis mais sofisticados do processo logístico.

Foi utilizada no estudo a caracterização proposta por Sink (1996). A partir de pesquisa com representantes de diversos setores industriais norte-americanos, Sink (1996) propôs a segmentação da indústria logística em cinco dimensões: serviços oferecidos, escopo geográfico de atuação, tipos de indústria atendidas, características dos ativos e atividade de origem.

Fleury e Ribeiro (2001b) constataram:

- Serviços oferecidos: todas as empresas ofereciam os seguintes serviços: transporte rodoviário, transporte aéreo, armazenagem, disponibilização de recursos dedicados, logística integrada, gestão da informação logística, controle e pagamento de fretes e documentação. Somente três delas oferecem serviços de transporte marítimo, e duas soluções logísticas para clientes potenciais.

- Escopo geográfico: todas atuam no mercado brasileiro e quatro têm atuação global.

- Indústrias atendidas: a pesquisa aponta uma clara tendência em direção a especialização. Muitos operadores vêm buscando maior especialização setorial e customização. Os setores 
com maior potencial são: automotivo, eletroeletrônica, computadores, telecomunicação, química, alimentos e papel.

- Infra-estrutura disponível: todos possuem frotas próprias e armazéns e, também, subcontratam terceiros, sobretudo para transporte rodoviário, aéreo, operações de courier. Também são terceirizados com freqüência o desenvolvimento de softwares, transporte marítimo, ferroviário, armazenagem e aplicações de EDI. Todas as empresas utilizavam intensivamente a TI.

- Origem: sete das oito empresas pesquisadas originaram-se de empresas de transporte e armazenagem; Cinco deles são empresas nacionais e três estrangeiras.

Entre os problemas enfrentados pelos operadores logísticos foi apontada a importância do estabelecimento de relação de confiança com clientes, elevados investimentos em tecnologia, custos dos processos de venda dos serviços, falta de mão de obra qualificada e intensificação da concorrência.

Os resultados encontrados por Fleury e Ribeiro (2001b), de forma geral, são semelhantes aos verificados na indústria americana e descritos na literatura (LIEB; BENTZ, 2005; LIEB, 1998). As discrepâncias observadas decorrem das diferenças estruturais entre os dois países, tais como complexidade dos impostos e problemas na infra-estrutura dos modais no Brasil, e não de aspectos internos à indústria logística.

Os autores constataram que os operadores brasileiros:

- Têm dificuldade para atender clientes com diferentes necessidades. Há uma tendência clara no mercado no sentido de uma maior especialização e capacitação para oferecer atendimento customizado aos clientes.

- Concordaram que o fator de maior impacto no setor vem sendo a pressão por redução de preços e melhoria no nível dos serviços. A TI é vista como a principal oportunidade para atingir simultaneamente estes dois objetivos. Assim, para permanecerem competitivos, os operadores devem buscar maior capacitação em TI.

Finalmente, na Europa e nos EUA, um dos atributos que mais vem sendo valorizado pelos clientes é a capacidade dos operadores para implantar ferramentas de TI que melhorem as operações logísticas dos clientes. Os autores não detectaram este fenômeno no Brasil. A maioria das embarcadores ainda não considera os operadores como uma fonte de capacitação em tecnologia de informação. Fleury e Ribeiro (2001) concluem ressaltando a importância, para estes agentes, de estarem preparados para ocupar este novo papel. 


\section{OPERADOR LOGÍSTICO 1}

\subsection{Caracterização do operador logístico 1 (OL 1)}

OL 1 é um operador logístico internacional que atua enquanto prestador de serviços de importação e exportação. Está capacitado para atuar na gestão das operações logísticas internacionais e vem experimentando nos últimos cinco anos um crescimento surpreendente: enquanto o mercado crescia apenas 5\%, a empresa cresceu, em média, $20 \%$ ao ano.

Em 1985, quando foi fundado, OL 1 atuava exclusivamente como despachante aduaneiro. Assim, suas atividades restringiam-se a elaboração da documentação e execução dos procedimentos burocráticos necessários ao processo de importação e exportação.

Em 1990 começou a operar como agente internacional de cargas (freight forwarder), contratando espaço em navios e aeronaves para enviar e receber mercadorias. Para viabilizar esta nova atividade, estabeleceu parcerias com outros agentes de carga em diferentes países. Estes parceiros executavam as tarefas necessárias à realização das atividades no exterior. Entretanto, não constituíam uma rede, já que atuavam de forma isolada.

Em 1992, com o estabelecimento de parceria com um grande operador logístico "A", OL 1 passou a integrar uma ampla e bem estruturada rede, tornando-se capaz de executar suas atividades em bases mundiais. "A" é uma grande empresa multinacional com mais de 150 anos de experiência no setor e que está presente em 85 países. Suas atividades envolvem mais de 10 mil profissionais em mil centros de serviços cobrindo a Ásia (Pacífico), Europa, Oriente Médio, África, América do Norte e América Latina.

O OL 1 possui 450 empregados alocados em 12 escritórios espalhados pelo Brasil. Sua sede está na cidade de São Paulo e mantém filiais em Santos, Campinas, Jacareí, Manaus, Rio de Janeiro e nos aeroportos de Guarulhos e Viracopos, além de inúmeros agentes subcontratados nos principais portos e aeroportos do país. Tem uma estrutura horizontal em que as quatro diretorias da empresa - despacho aduaneiro, frete internacional, operações e financeira - partilham o poder.

A empresa possui uma frota de 42 caminhões para o transporte terrestre e um único armazém em Guarulhos, São Paulo. Assim, utiliza com freqüência transporte terrestre e armazenagem de terceiros.

No exterior, a parceria com o operador logístico internacional "A" garante uma bem estruturada rede de armazéns e ampla frota terrestre. Por meio desta parceria, OL 1 dispõe de 
armazéns e frota nos cinco continentes, e é capaz de atuar em bases mundiais. A empresa aciona seus parceiros para execução de serviços nos diversos países onde atuam e, em contrapartida, realiza as mesmas tarefas no Brasil. Atende as necessidades de seus clientes combinando o apoio de uma rede mundial de agentes e o uso intensivo da TI.

\subsubsection{Processo logístico e atividades de OL 1}

Como já visto, os operadores atuam na gestão dos processos logísticos, administrando os fluxos e estoques de materiais, produtos e informação entre os agentes da rede. No caso dos operadores internacionais, os processos logísticos envolvem exportação e/ou importação de materiais e produtos para empresas localizadas em diferentes países.

Os processos de importação e exportação são, de forma geral, semelhantes, e envolvem as mesmas atividades logísticas. As diferenças verificam-se, sobretudo, nos procedimentos aduaneiros dos diferentes países. No Brasil, segundo o Ministério do Desenvolvimento, Indústria e Comércio Exterior, o processo de exportação pode ser desmembrado nas seguintes etapas:

1. Recebimento do pedido de compra do importador

2. Negociação quanto aos preços, prazos, pagamentos e INCOTERMS (International Commercial Terms). Os INCOTERMS estabelecem um conjunto de regras quanto ao pagamento de fretes, seguro, local de embarque e desembarque, e desembaraço aduaneiro.

3. Elaboração e envio da fatura pró-forma ao importador onde são detalhadas todas as condições de venda. O importador solicita a abertura da carta de crédito (Letter Credit) e envia ao exportador.

4. Após a produção das mercadorias é emitida a nota fiscal para trânsito no território nacional.

5. Preparação da mercadoria para embarque e solicitação do Registro de Exportação (RE) no Sistema Integrado de Comércio Exterior (SISCOMEX). O SISCOMEX é um instrumento informatizado por meio do qual é exercido o controle governamental sobre o comércio exterior.

6. É realizado o carregamento da carga com destino ao armazém para estufagem ou para consolidação com outras cargas. Estufagem é a colocação de cargas em um container, para que sejam movimentadas e transportadas como um único volume. Consolidação é o 
agrupamento de várias cargas com o mesmo destino final visando diminuir custos (FLEURY, 2002).

7. Elaboração da fatura comercial (commercial invoice), documento internacional equivalente a nota fiscal, e emissão do packing list que indica os volumes que serão embarcados e os seus conteúdos. O packing list é necessário para o desembaraço da mercadoria junto a Alfândega e para orientação do importador.

8. Transporte da mercadoria até o porto ou aeroporto para embarque.

9. Solicitação do despacho aduaneiro:

- Registro da declaração para despacho de exportação (DDE)

- Confirmação da presença da carga.

- Recepção dos documentos de despacho e registro no SISCOMEX

- Parametrização: seleção dos despachos de exportação para um dos canais de conferência aduaneira: verde, laranja ou vermelho. No canal verde, o desembaraço é feito automaticamente, não havendo conferência da documentação e nem das mercadorias. No canal laranja ocorre apenas o exame da documentação. Finalmente, no canal vermelho, ocorrem tanto a verificação das mercadorias como da documentação.

10. Pagamento do frete e do seguro pelo exportador ou importador, conforme o acordado.

11. Recebimento do Conhecimento de Embarque (Bill of Landing), documento emitido pela empresa de transporte internacional atestando o recebimento da carga, as condições de transporte e de entrega da mercadoria.

12. Averbação de embarque: após o embarque efetivo da mercadoria é efetuado o registro no SISCOMEX e emitido o comprovante de exportação.

No caso das importações, verificam-se as seguintes particularidades:

1. As mercadorias importadas podem ser armazenadas em depósitos alfandegados até sua liberação pela Alfândega.

2. Recepção dos documentos de despacho e registro da declaração de importação (DI) no Sistema Integrado de Comércio Exterior (SISCOMEX) pela Aduana.

Assim, o processo logístico internacional envolve uma série de atividades além de um complexo trâmite burocrático. O operador logístico internacional realiza, segundo Demaria (2004), as seguintes atividades nos processos de exportação e/ou importação:

1. Retirada do produto da área de produção ou distribuição

2. Separação, embalagem e marcação.

3. Consolidação do lote para exportação (estufagem)

4. Licença (se necessário) e despacho aduaneiro de exportação. 
5. Documentação para o transporte e apólices de seguro

6. Transporte terrestre até o terminal de embarque (porto ou aeroporto)

7. Manuseio, empilhamento e armazenagem.

8. Transferência da área de armazenagem até o navio ou avião.

9. Estivagem (colocação e arrumação dentro do navio ou avião)

10. Transporte internacional

11. Desestivagem (retirada de dentro do navio ou avião)

12. Movimentação dos produtos até a área de armazenagem.

13. Conferência, marcação, separação e empilhamento.

14. Licença (se necessário) e despacho aduaneiro de importação

15. Identificação, desempilhamento e entrega.

16. Transporte terrestre até o centro de distribuição.

17. Desconsolidação do lote.

18. Distribuição final ou entrega local.

OL 1 está capacitado para atuar desde a retirada do produto no fabricante ou em um $\mathrm{CD}$, até a entrega no país de destino. Desenvolve todas as atividades listadas acima, além de assessoria e consultoria, administração das necessidades de compra dos clientes e gerenciamento dos processos. Portanto, é capaz de oferecer um serviço de terceirização total da logística na exportação e/ou importação.

No processo de exportação, OL 1 atua no ciclo de distribuição física das empresas, e no processo de importação, no ciclo de suprimentos. No ciclo de apoio à manufatura realiza a importação dos materiais e abastece a linha de produção de uma empresa de autopeças. Realiza, ainda, logística reversa (BOWERSOX; CLOSS, 2001)

Os clientes de OL 1 são empresas dos mais variados setores, com necessidades, estruturas organizacionais e focos estratégicos diversos. Destacam-se: grandes redes de supermercados, indústria farmacêutica, cosméticos, autopeças, siderurgia e metalurgia, eletroeletrônico, informática, etc. Dentre seus fornecedores estão: armadores, companhias aéreas, agentes de carga, despachantes aduaneiros, transportadoras, armazéns e outros operadores logísticos. Finalmente, seu parceiro é um grande operador logístico "A”, participando como agente de uma ampla rede logística.

A figura abaixo retrata o fluxo de materiais e produtos em um processo logístico genérico realizado pelo OL 1. 
Figura 21- Fluxo de materiais e produtos de OL 1

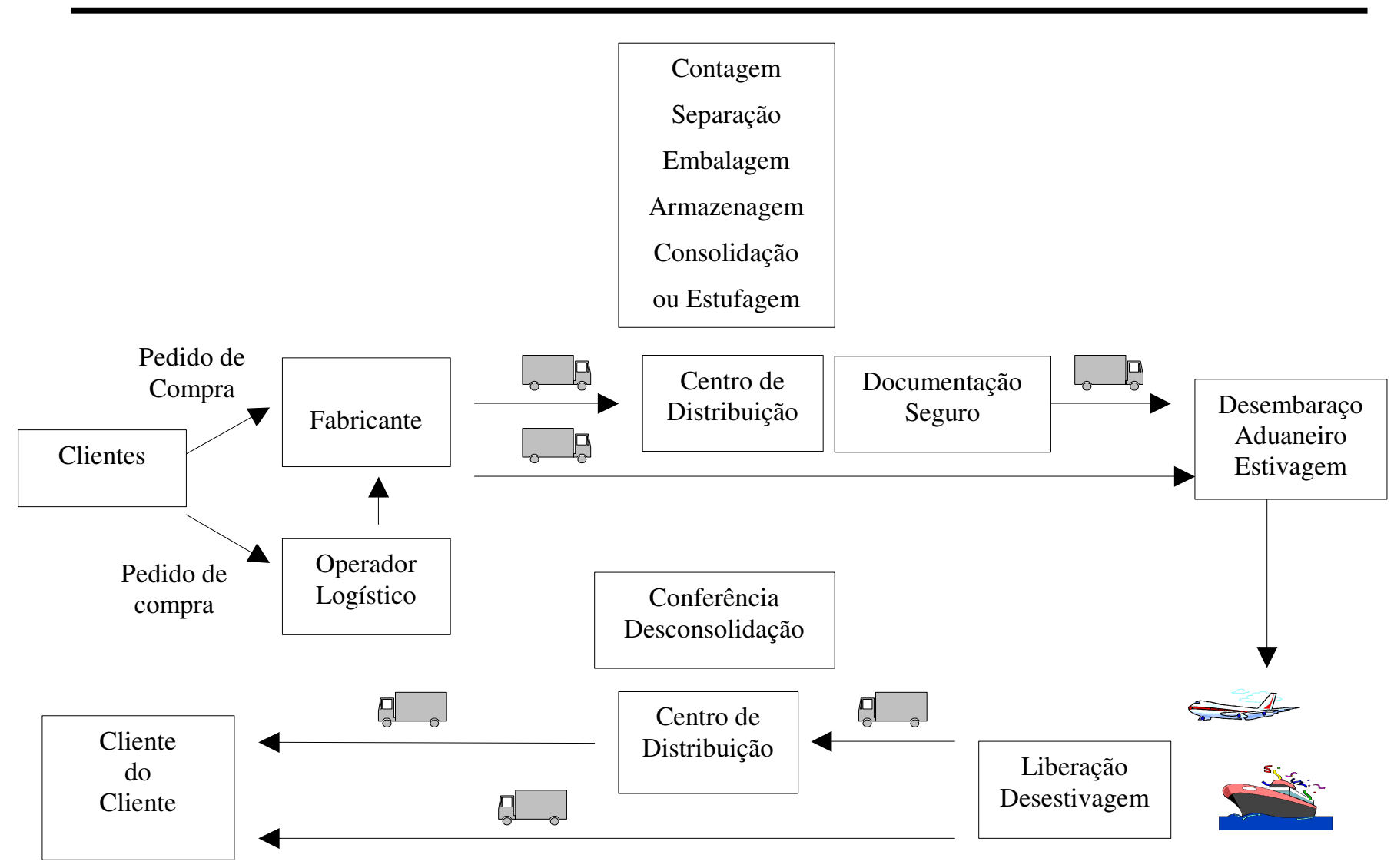

Fonte: adaptado de material fornecido por OL 1 (2007).

O exportador recebe o pedido de compra do importador e emite a fatura pró-forma onde constam as condições de venda (INCOTERMS). Após o aceite pelo importador, remete o pedido de compra para o fabricante e, simultaneamente, para o OL 1 . O operador monitora o fabricante e, assim que o produto está pronto, faz a coleta da carga. O produto pode ser armazenado em um CD antes de ser embarcado, ou pode ser transportado diretamente para o embarque marítimo ou aéreo.

No caso de ficar depositado em um centro de distribuição antes do embarque, o operador pode realizar uma série de atividades, como: contagem, separação, embalagem, colocação de lacre, armazenagem, consolidação ou estufagem. Em seguida, o operador emite os documentos para exportação e contrata o seguro da carga. Finalmente, realiza o desembaraço aduaneiro na alfândega e coloca a carga dentro do navio ou avião para ser transportada ao destino (estivagem). 
No destino, seu parceiro "A", ou um agente da rede, providencia a liberação da carga na alfândega e entrega diretamente para o cliente do cliente ou deposita em algum armazém. Se a carga for armazenada, "A" pode realizar novamente todas as atividades já citadas.

\subsubsection{Fluxo de informação e TI no OL 1}

Embora houvesse forte interação entre as diversas atividades de OL 1, até 1995 elas eram executadas de forma isolada e, portanto, não atendiam ao conceito de logística. Os computadores eram utilizados exclusivamente para rodar os aplicativos que OL 1 comprava no mercado e que geravam os formulários e documentos para execução do processo de importação e exportação.

A história da TI na empresa começa a mudar em 1999, quando um grande cliente da área de telecomunicações exigiu que seus prestadores de serviço trabalhassem integrados ao seu sistema corporativo. OL 1 deveria ligar-se à rede privada deste cliente para receber e enviar informações. A troca de informações nestes sistemas proprietários exigia a utilização de terminais em rede e a adoção do Electronic Data Interchange (EDI).

Com dificuldade para implantar as mudanças necessárias para se adequar a esta nova situação, OL 1 decidiu contratar, como diretor de operações, um profissional que havia participado do desenvolvimento do EDI em uma grande empresa. A partir daí, gradativamente, o sistema de informação de OL 1 foi sendo desenvolvido. O sistema possui duas partes, importação e exportação, e cada parte é dividida em módulos.

Os primeiros módulos desenvolvidos foram "geração de documentos" e "faturamento, custeio e fiscal". Em seguida, o módulo de "gestão de pedidos". E, finalmente, o módulo de "acompanhamento", que engloba os demais e faz a gestão de todo o processo. Cada módulo executa uma função específica, sempre buscando a integração entre as informações.

- O módulo "geração de documentos" atende às necessidades internas do operador emitindo todos os documentos necessários ao processo de exportação e importação: packing list, invoice, fatura, certificado de origem, certificado de carga perigosa, certificado de análise, nota fiscal, DI, etc.

- O módulo "faturamento e custeio" disponibiliza as informações contábeis, solicitando recursos para liberação da mercadoria, calculando o valor dos impostos, etc.

- O módulo "gestão de pedido" permite que OL 1 acompanhe todo o processo de compra, desde a solicitação ao fornecedor até a entrega do produto ao comprador. A empresa não atua na seleção e negociação com fornecedores. O MRP do cliente envia diretamente para 
o sistema de OL 1 um arquivo (via EDI ou FTP) solicitando a compra e, a partir daí, OL 1 executa todo o processo.

- Finalmente, o "módulo de acompanhamento" engloba os demais e faz a gestão de todo o processo. Através dele, o cliente pode ter acesso a todas as informações referentes ao seu pedido de compra e entrega, tais como: data de abertura, local de embarque, valor do frete, valor dos impostos, etc. O cliente pode buscar as informações pelo número do processo, pela data, por algum evento específico, etc. Este módulo é responsável pela interface entre o operador logístico e seus clientes externos.

A figura 22 abaixo representa o fluxo de informação genérico em um processo de exportação. O processo de importação é semelhante.

Figura 22 - Fluxo de informação do OL 1

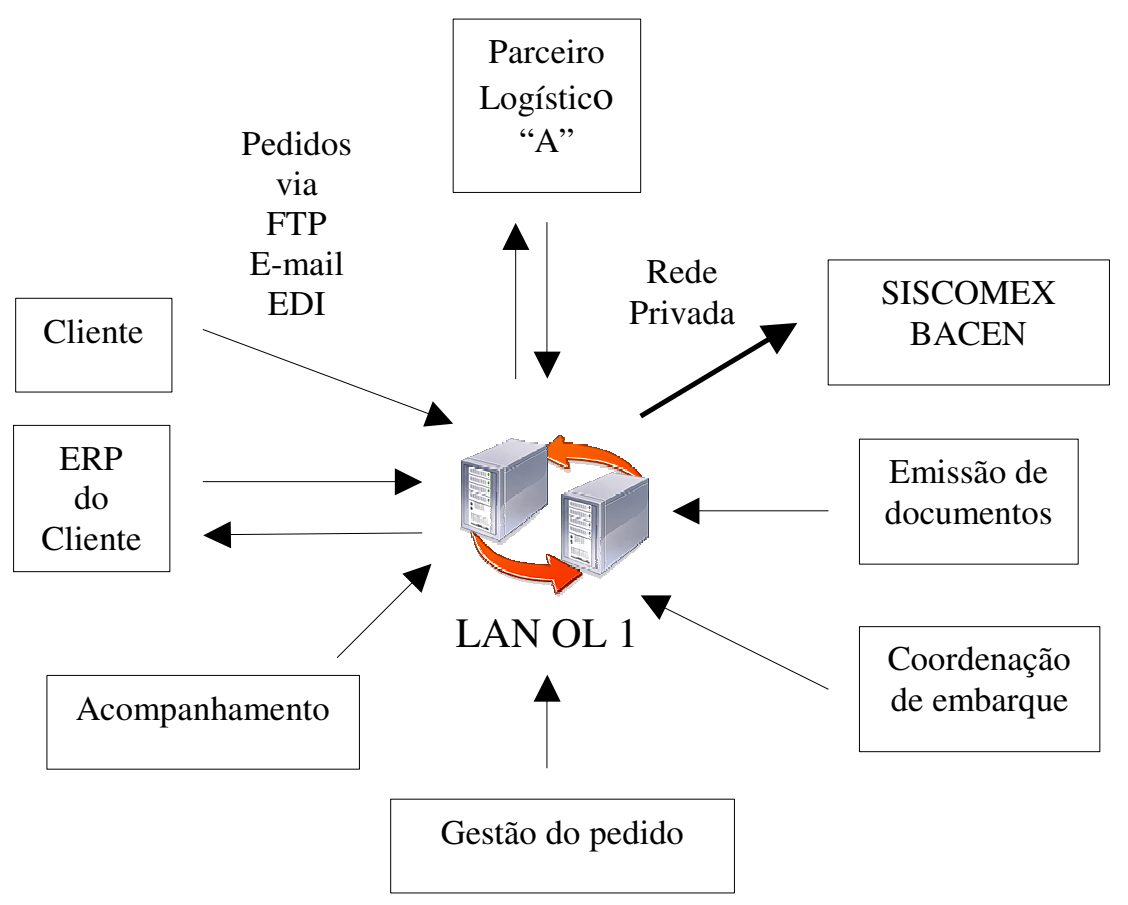

Fonte: adaptado de material fornecido por OL 1 (2007).

O fluxo de informação tem inicio a partir da demanda do cliente. Há situações onde o ERP do cliente envia o pedido diretamente para a rede interna (LAN) de OL 1, ou OL 1 capta as informações diretamente no ERP dos clientes. Em outros casos, o cliente envia a solicitação por transferência de arquivos (FTP), EDI ou por e-mail. 
A partir do pedido, OL 1 dá inicio ao processo de exportação. Prepara e emite toda a documentação necessária, providencia o desembaraço aduaneiro por meio de uma linha dedicada, acessando remotamente o banco de dados do SISCOMEX.

Finalmente, agenda as datas e os meios de transporte (caminhão, navio ou avião) para a exportação da carga. No caso do transporte marítimo, os armadores desenvolveram um sistema denominado "Supervia de Dados" que permite o intercâmbio de documentos entre entidades e autoridades. O sistema permite que os operadores enviem dados, via EDI, diretamente para as autoridades portuárias, atualizando o sistema.

Finalmente, tanto "A" quanto os clientes de OL 1 podem acompanhar seus processos de exportação e/ou importação por meio do módulo de "acompanhamento", que oferece informações atualizadas.

Atualmente, a TI está organizada de forma centralizada em OL 1. A gestão dos equipamentos e o desenvolvimento dos sistemas estão concentrados na equipe de TI que é composta pelo diretor de operações, com formação em engenharia eletrônica, dois gerentes analistas de sistemas, dois programadores e dois técnicos para suporte à rede. A equipe desenvolve aplicativos, oferece suporte para usuários internos e externos, e serviço de manutenção de rede e hardware.

\subsubsection{Análise do papel da TI no apoio às atividades desenvolvidas}

As tecnologias utilizadas nas atividades logísticas serão analisadas a partir do posicionamento estratégico do operador, por meio da perspectiva interna e do mercado atendido (BERGLUND, 1997).

\section{Com relação à perspectiva interna}

OL 1 oferece todas as atividades necessárias para o desenvolvimento de um processo logístico internacional, está integrado horizontalmente a uma rede logística coordenada pelo operador logístico "A”, e capacitado para desenvolver soluções para os clientes.

O foco de OL 1está na gestão do processo de exportação e importação. Assim, não utiliza sistemas de apoio às atividades operacionais da logística, como WMS ou TMS, mas somente tecnologias voltadas para gestão dos processos. O sistema de informação utilizado por OL 1 foi desenvolvido internamente com o objetivo de apoiar o processo logístico do operador, dando suporte ao desenvolvimento de uma solução completa para os processos de importação e exportação. 
OL 1 tem como meta ser flexível, adequando-se a diferentes clientes com diferentes necessidades, e ser eficaz, adicionando o máximo de valor ao processo logístico por meio de qualidade e diferenciação. Além da gestão eficiente dos fluxos e estoques, OL 1 procura se diferenciar por meio do desenvolvimento de processos e disponibilizando as informações para seus clientes (BOWERSOX; CLOSS, 200; BOWERSOX; CLOSS; STANK, 1999).

Capacidade para se adequar a diferentes situações e parceiros, diferenciação, e o estabelecimento de alianças externas exigem intensa troca de informação e, portanto, o uso intensivo da TI. A TI vem contribuindo para a criação, circulação e difusão das informações entre OL 1, seus clientes e seu parceiro "A”, facilitando a coordenação do processo logístico e possibilitando a customização e adaptação do operador aos diferentes clientes e oportunidades. A TI tem, portanto, papel central (BOWERSOX; DAUGHERTY, 1995).

Mas, para que a TI contribua para a competitividade do processo logístico é necessário haver alinhamento entre a estratégia do negócio e da tecnologia (HENDERSON; VENKATRAMAN, 1993). No caso de OL1, a estratégia do negócio determinou a estratégia de TI adotada pela empresa e exigiu o estabelecimento de infra-estrutura de TI e processos adequados. O sistema desenvolvido por OL 1 deu apoio a estratégia de desenvolvimento integral do processo de importação e exportação e permitiu a integração horizontal com seu parceiro "A".

OL 1 enquadra-se, portanto, no alinhamento denominado por Henderson e Venkatraman (1993) de "Transformação Tecnológica". Neste alinhamento estratégico, a TI pode ser avaliada pelo que adicionou ao produto ou serviço final da empresa. Há a busca por tecnologias que viabilizem a estratégia do negócio. No caso de OL 1, a TI permitiu a diferenciação dos serviços e apoiou a ampliação do escopo de atuação facilitando a troca de informação entre o operador e seu parceiro "A".

Finalmente, analisando a importância das aplicações de TI presentes e futuras para o operador logístico 1, pode-se concluir que seu sistema de informação contribui decisivamente para o seu desempenho na medida em que dá suporte integral ao desenvolvimento do processo de exportação e importação. Portanto, o OL 1 tem necessidade de TI confiável. Não estão previstas, entretanto, novas aplicações, mas apenas atualizações do sistema. OL 1 pode ser enquadrado, portanto, no quadrante "Fábrica" (NOLAN; MCFARLAN, 2005). 


\section{Com relação à perspectiva do mercado atendido}

OL 1 atua com empresas de qualquer setor, com porte e necessidades variadas, e em todos os ciclos do processo logísticos. Seus diferenciais são: qualidade dos serviços, disponibilização da informação e, sobretudo, capacidade de atuar em praticamente qualquer lugar do planeta e de executar integralmente o processo de exportação e/ou importação.

O sistema permite que os clientes acompanhem integralmente o processo de exportação e importação, oferecendo informações atualizadas e customizadas de acordo com a necessidade de cada cliente.

Com relação às necessidades logísticas de seus clientes:

- Não existem diferenças significativas nos processos logísticos dos clientes nos diferentes setores onde atua. Segundo o diretor de operações, o processo logístico internacional envolve as mesmas atividades e, portanto, utiliza as mesmas ferramentas de TI. Para todos os clientes, OL 1 utiliza o seu sistema de gestão da importação e exportação. O que foi observado é que características do setor, ou mesmo particularidades dos clientes, podem afetar o formato que o cliente deseja ver as informações. Nestes casos, OL 1 customiza as interfaces de seu sistema, disponibilizando as informações no formato adequado. $\mathrm{O}$ “módulo de acompanhamento", por exemplo, é customizado para atender as necessidades dos diferentes clientes nos diferentes setores. O varejo, por exemplo, organiza suas compras em "ondas", definidas de acordo com as épocas do ano (dia das crianças, natal, etc.). OL 1 customizou o "módulo de acompanhamento" para disponibilizar as informações de importação neste formato.

- Quanto à política de produção, OL 1 atua no ciclo de apoio à manufatura de uma única empresa do setor de autopeças, importando os materiais e abastecendo a sua linha de produção. Não existem, portanto, elementos que permitam confirmar ou refutar a proposição.

\subsubsection{TI e a gestão integrada da logística}

Quanto a gestão integrada da logística e ao estabelecimento das redes de valor, OL 1 mantém nível elevado de integração com alguns clientes. O sistema utilizado por OL 1 é capaz de trocar informação diretamente com o ERP dos clientes. Quando isto não é possível, o cliente pode enviar a solicitação por transferência de arquivos (FTP) ou por $e$-mail.

OL 1 também está plenamente integrado com seu parceiro "A": O operador tem permissão para atualizar as informações diretamente no banco de dados de "A", assim como 
"A" tem acesso direto aos seus sistemas. Os parceiros ainda trocam documentos referentes às suas operações por meio de EDI.

OL 1 não está, de forma geral, integrado a seus fornecedores. A exceção são os armadores, que desenvolveram um sistema que permite que os usuários de seus serviços atualizem e captem informações diretamente em seus bancos de dados e o sistema da Receita Federal (SISCOMEX) onde o operador pode realizar os registros e atualizar as informações diretamente em seu banco de dados (BOWERSOX; CLOSS, 2001; BOWERSOX; DAUGHERTY, 1995; ASSUMPÇÃO, 2003; TURBAN; RAINER; POTTER, 2003).

OL 1 está, portanto, plenamente integrado ao seu parceiro "A" e a alguns de seus clientes e integrado parcialmente aos fornecedores. $\mathrm{Na}$ classificação proposta por Venkatraman (1994), OL 1 pode ser enquadrado no nível de "estabelecimento da rede de negócio". Isto porque embora não plenamente integrado a todos os agentes, os relacionamentos que mantêm garantem competências que permitirão produzir produtos e serviços superiores.

Com relação à coordenação, OL 1 não é responsável pela sincronização dos fluxos entre os agentes da cadeia, uma vez que somente recebe o comunicado de venda e realiza a entrega. O estabelecimento dos parâmetros e regulamentações, tais como codificação de materiais e produtos, é determinado por seus clientes.

Finalmente, a parceria com o operador logístico “A”, é motivada pela configuração aditiva (BRITTO, 2002) visando um aumento de escala, e está fortemente estabelecida, já que cada empresa vê a outra como extensão de seu negócio (LAMBERT; EMMELHAINZ; GARDNER, 1996).

Assim, no caso de OL 1, foi possível observar de forma parcial os fundamentos que permitem a integração logística: integração e coordenação das várias atividades e o estabelecimento de parceiras com outros agentes da rede (BOWERSOX; CLOSS; STANK, 1999; BERGLUND, 1999; CHOPRA; MEINDL, 2001).

Nos segmentos onde há integração logística, os fluxos e estoques de matérias, serviços e informação são administrados como um processo contínuo. Portanto, há o estabelecimento de uma rede de valor: os agentes operam de forma colaborativa e ocorre um nível elevado de integração, compartilhando grande parte das informações (BOVET; MARTHA, 2001). 


\section{OPERADOR LOGÍSTICO 2}

\subsection{Caracterização do operador logístico 2 (OL 2)}

O operador logístico 2 (OL 2) é uma multinacional que presta serviço em distribuição e operações logísticas. A empresa nasceu nos EUA, em 1934, passou por várias fusões e aquisições e, atualmente, é parte de uma grande distribuidora internacional do setor de alimentos e bebidas.

Quando foi fundada, OL 2 operava como atacadista no setor de papel, atendendo restaurantes, lojas de varejo e indústrias. Em 1956, passou a fornecer para um restaurante que, mais tarde, tornou-se uma grande rede de fast-food. Desde então a parceria com esta rede somente se fortaleceu. A história de OL2 está intrinsecamente ligada à história desta rede.

A rede fast-food (RFF) é, atualmente, uma das grandes empresas de serviço rápido de alimentação do mundo, atuando em 118 países. O OL 2 atende 8 mil restaurantes da rede no mundo inteiro, executando e controlando todo o fluxo de materiais e produtos que abastecem os restaurantes. É, atualmente, a maior distribuidora de seus produtos nas Américas. No Brasil, assim como no Canadá, Caribe (Porto Rico) e América Central, é parceiro logístico exclusivo da rede.

Ainda na década de 70, a RFF adotou o conceito “one stop shop": um único distribuidor deveria fornecer todos os produtos necessários para a operação das lojas. O OL 2 assumiu esta tarefa e passou a distribuir, além dos produtos para embalagem, alimentos congelados e secos.

Em 1979, a RFF chegou ao Brasil. Em 1982 trouxe seus já parceiros, OL 2 e uma empresa fornecedora de produtos a base de carne, para atender seus quatro restaurantes pioneiros: três no Rio de Janeiro e um em São Paulo. Mais tarde, em 1988, foi a vez do fornecedor de pães e bolos também ingressar no mercado brasileiro.

Atualmente, a RFF tem no Brasil mais de mil pontos de venda distribuídos em 134 cidades que atendem cerca de 1,6 milhões de clientes ao dia. Destes pontos de venda, 542 são restaurantes, 549 são quiosques e 49 são cafés. O OL 2 é a empresa responsável pela aquisição, armazenagem e distribuição dos produtos, desde o fornecedor até a entrega nos pontos de venda.

Desde sua fundação, a RFF mantém como uma de suas principais características a padronização de seus produtos, pontos de venda e forma de atendimento. Todos os restaurantes da rede oferecem produtos com as mesmas características e padrão de qualidade. 
Para garantir a homogeneidade, a rede controla toda a cadeia, desde a produção de matéria prima até a forma de preparação do alimento em seus restaurantes. Para enfrentar este desafio, OL 2 mantém no Brasil uma unidade de negócio que atende exclusivamente a rede; e outra unidade para atender empresas do setor de alimentos.

A unidade que atende empresas do setor de alimentos abastece cerca de 1.000 empresas de alimentação com um amplo portfólio de produtos secos, resfriados e congelados. Neste caso, os fornecedores são desenvolvidos pela OL 2. Ocorre, ainda, o manuseio dos produtos no processo logístico. Isto porque não há padronização e, portanto, cada pedido deve ser embalado individualmente. Finalmente, os armazéns e caminhões são compartilhados pelos diferentes clientes.

A unidade que atende exclusivamente a rede opera de acordo com as suas necessidades e exigências, respeitando o rígido padrão que caracteriza a marca. A RFF desenvolve seus próprios fornecedores e exige que todos os produtos sejam embalados em caixas padrão. Assim, a unidade executa apenas o manuseio de caixas. Além disto, mantém armazéns e parte de sua frota de caminhões exclusivamente para atender seu cliente. A pesquisa foi realizada nesta unidade de negócios, denominada OL 2 - fast-food.

Desde que se instalou no Brasil, a rede fast-food vem expandindo seus pontos de venda. Conseqüentemente, seus principais fornecedores e prestadores de serviços vêm sendo obrigados a ampliar suas instalações e investir em infra-estrutura.

Em 1986, já atendendo vinte e oito restaurantes da rede, o OL 2 construiu um centro de distribuição - com armazéns para congelados - na cidade de Embu, São Paulo. Foi instalada, no mesmo local, uma unidade do fornecedor de carnes. As carnes podiam ser deslocadas sem a necessidade de frete, diretamente do fornecedor para o distribuidor, eliminando os custos do transporte e reduzindo o tempo de deslocamento. A RFF já vinha implantando este conceito de negócio na Rússia e na Alemanha com resultados positivos.

O intenso crescimento experimentado pela rede no final da década de 90 exigiu, novamente, investimentos de seus principais fornecedores para atender a demanda crescente. Em 1999 foi criado um centro de excelência (CE) em São Paulo.

No CE são realizadas a produção, armazenagem e distribuição de alimentos para a rede no Brasil. Tem cerca de $160.000 \mathrm{~m}^{2}$ de área construída onde estão abrigados seus três principais fornecedores: OL 2 e os fornecedor de carnes e de pães. São produzidas cerca de três mil dúzias de pães por hora e processadas mais de 100 toneladas de carne bovina, de frango e de peixe por dia. Além das três empresas, o CE abriga uma unidade central onde 
estão os serviços de telefonia, limpeza, segurança, ambulatório, etc.; que são comuns a todas as empresas.

O OL 2 mantém no CE seu escritório central com quatro unidades de negócio. Além da unidade exclusiva de negócios da RFF, uma unidade que abastece cerca de 1.000 empresas do setor de alimentação, uma unidade que oferece serviços de armazenagem seca refrigerada e congelada, transporte, distribuição e uma unidade que presta serviços nas áreas de TI, finanças e recursos humanos para as empresas do grupo.

O principal objetivo com o estabelecimento do $\mathrm{CE}$ era otimizar a produção e a distribuição de alimentos para a rede. Os processos são otimizados pela possibilidade de transferir diretamente, por meio de portas que interligam as empresas, os produtos do fornecedor de carnes e de pães para os armazéns do OL 2. Esta forma de operar elimina despesas com frete e reduz significativamente o tempo de transferência dos produtos entre fornecedor e distribuidor.

O OL 2 mantém no CE seu mais importante Centro de Distribuição (CD), com capacidade de armazenar 7.700 paletes. Além do CD de São Paulo, possui outros dois localizados em Recife e Curitiba. O CD de Curitiba atende a $12 \%$ dos restaurantes da rede localizados no Paraná, Santa Catarina e Rio Grande do Sul. E, o de Recife, atende os outros 9\% dos restaurantes e opera com frete retorno de cargas com destino a Alagoas, Sergipe, Bahia, Espírito Santo e São Paulo. Todos os Centros de Distribuição possuem três tipos de armazéns: seco, congelados $\left(-18^{\circ} \mathrm{C}\right)$ e resfriados $\left(-4^{\circ} \mathrm{C}\right)$.

A empresa possui, ainda, dois Centros de Apoio (CA): Rio de Janeiro e Juiz de Fora. O do Rio de Janeiro mantém uma equipe de motoristas para distribuição de produtos vindos do CD São Paulo e atende os restaurantes do Rio de Janeiro, Espírito Santo e alguns de Minas Gerais. O CA de Juiz de Fora, que está localizado dentro de uma unidade do fornecedor de pães e faz a distribuição para os restaurantes do Rio de Janeiro e Minas Gerais.

Além dos centros de distribuição e de apoio, a empresa possui uma frota com mais de cem caminhões especializada no transporte de produtos secos, resfriados e congelados. Os caminhões, feitos sob encomenda, possuem dois evaporadores, que resfriam os alimentos, e divisórias móveis que deixam cada compartimento com o tamanho necessário para atender a rota percorrida. 


\subsubsection{Processo logístico e atividades do OL 2 - fast-food}

A OL 2 - fast-food é responsável pela aquisição, armazenamento e distribuição dos produtos para os restaurantes da RFF no Brasil. O processo logístico abrange, portanto, desde o recolhimento dos produtos nos fornecedores até a entrega no ponto de venda final.

Assim, OL 2 atua nos ciclos de distribuição física ou logística de saída, ligando os diversos fornecedores ao seu centro de distribuição, e no de suprimentos ou logística de entrada, ligando seu centro de distribuição aos inúmeros restaurantes da rede. Estabelece a interface entre os ciclos de distribuição dos fornecedores e o de suprimentos da rede fast-food. OL 2 não atua no ciclo de apoio à manufatura, ou logística interna, já que atende exclusivamente a uma rede de lanchonetes onde não ocorre o processo de produção (BOWERSOX; CLOSS, 2001; PORTER; MILLAR, 1985).

Quanto aos fornecedores, a rede trabalha com poucas empresas que obedecem a rigoroso controle de qualidade. No Brasil, são cerca de 60 fornecedores. Algumas empresas fornecem exclusivamente para a rede. Outras são indústrias destacadas em seus segmentos. A rede mantém, com muitos deles, relação estável e duradoura, caracterizando parcerias.

Dentre os fornecedores da rede, destacam-se:

- A - fornecedor de todos os produtos a base de carne bovina, frango e peixe. Como está localizada no $\mathrm{CE}$, as caixas são transportadas por meio de paletes diretamente para os armazéns de congelados do OL2 - fast-food

- B - fornecedor de todos os pães, bolos e tortas consumidos pela rede. Também está integrada fisicamente aos armazéns do OL2 - fast-food

- C - fornecedor de alface americana, cebola processada, mix de salada, tomates e picles de pepino para a rede. Os produtos são processados, embalados e acondicionados em caixas de papelão com a data de produção e validade, e enviadas para a câmara de expedição, onde a temperatura varia de 1 a $4^{\circ} \mathrm{C}$. No mesmo dia em que são processadas, são transportadas nos caminhões do OL2 - fast-food para o CD de São Paulo.

- D - fornecedor de batatas fritas. Processa em torno de 30 mil toneladas de batata ano para abastecer os restaurantes do Brasil. Os sacos de batatas fritas são acondicionados em caixas de papelão e armazenados em câmaras a $23^{\circ} \mathrm{C}$ negativos. Finalmente, são transportados nos caminhões do OL2 - fast-food para o CD de São Paulo.

- E - dois fornecedores de leite e derivados. As empresas adaptaram parte de suas fábricas para a produção dos ingredientes de acordo com as especificações da rede. 
- F - dois fornecedores de refrigerantes, sendo que um deles é também responsável pela produção do suco de laranja vendido nas lojas da rede e é o único fornecedor que entrega seus produtos diretamente nos pontos de venda.

- Outros fornecedores: fabricantes de embalagens, produtos de limpeza, molhos, guardanapos, etc.

Todos os produtos fornecidos são embalados em caixas. As caixas são transportadas pelos caminhões climatizados do OL2 - fast-food até o CD de São Paulo, onde são descarregadas e dão entrada nos armazéns.

O recebimento das mercadorias no CD de São Paulo é “cego", isto é, o motorista diz o número de caixas que será descarregado e este número é aceito como correto. Mais tarde, esta mercadoria será conferida e as informações deverão coincidir.

Feito o recebimento, as mercadorias vão ser armazenadas em um dos três tipos de armazéns. As carnes e as batatas vão para o armazém de congelados. Leite, derivados e hortifrutigranjeiros vão para o armazém de resfriados. E os pães e outros materiais, que podem ser armazenados à temperatura ambiente, vão para o armazém seco.

A figura 23 descreve o processo logístico desenvolvido por OL 2. 
Figura 23 - Fluxo de materiais e produtos do OL2 - fast-food

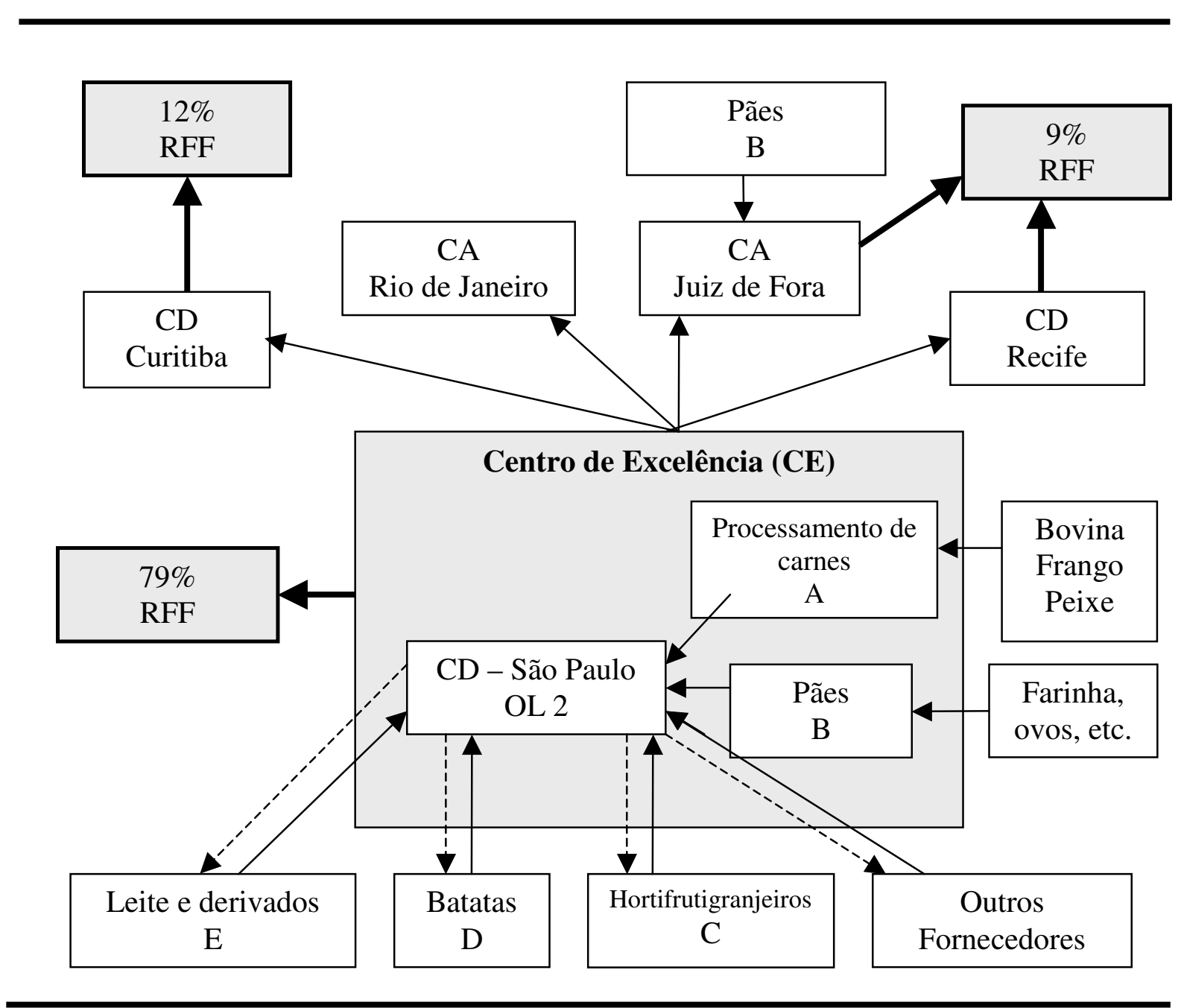

Fonte: executado pelo autor (2007).

O OL 2 - fast-food recebe diariamente os pedidos das lojas e, a partir deles, faz a separação de acordo com a rota estipulada para cada caminhão. Após a separação, é feito o carregamento do caminhão. Cada caminhão atende de quatro até, no máximo, dez pontos de venda de uma rota pré-estabelecida (em torno de mil caixas) e deve cumprir horários rígidos de entrega, não sendo tolerável atrasos superiores a 30 minutos.

O carregamento do caminhão é uma etapa importante no processo logístico. Primeiro, as caixas devem estar separadas pelo tipo: congelada, resfriada ou seca. Em seguida, deve ser feito o carregamento de cada compartimento tendo como objetivo tornar a descarga no ponto de venda o mais eficiente possível.

Vários procedimentos são importantes para facilitar o trabalho de descarga. Dentre eles: disposição dos pedidos de forma a estar acessível em cada ponto de entrega, observação 
o sentido do tráfego e a localização do ponto de venda na rua para definir o lado do caminhão por onde será feito o descarregamento.

Grande parte dos caminhões que saem do CD de São Paulo irá abastecer, diretamente, $79 \%$ dos pontos de venda da rede. Os demais têm como destino os CDs de Curitiba e de Recife, de onde partirão outros caminhões para abastecer as demais lojas. No caso particular das regiões Norte e Nordeste, a alface, o tomate e a cebola são remetidos por avião. Para garantir a qualidade é utilizado um sistema de resfriamento com gelo seco, isopor e mantas térmicas que garantem a manutenção da temperatura entre $1^{\circ} \mathrm{C}$ e $4^{\circ} \mathrm{C}$ durante o percurso.

\subsubsection{Fluxo de informação e TI no OL 2 -fast-food}

Em 1995, quando o atual diretor de TI começou a trabalhar no OL 2 - fast-food, a empresa operava com três sistemas isolados: controle das operações, financeiro e de contabilidade. E os motoristas preenchiam, manualmente, um relatório com todos os dados da rota de entrega.

Com a tarefa de implantar uma ERP, ao longo de quatro meses foi feita uma pesquisa sobre os softwares disponíveis no mercado. O OL 2 - fast-food considerava três aspectos importantes para sua decisão: tempo de implantação, custo e aderência ao negócio. Caso não fosse encontrado no mercado algum ERP que atendesse suas necessidades, a empresa desenvolveria o aplicativo internamente.

A primeira etapa foi analisar e documentar os processos da empresa, identificando o que poderia ser melhorado. Montou, então, um Request for Proposal (RFP), convidando os fornecedores a participar. No início eram 18 empresas e, ao final de quatro meses, o OL 2 fast food escolheu o ERP. O ERP foi implantado em março de 1997 e teve uma curva de aprendizado de cerca de três meses.

O ERP atende às necessidades básicas da empresa e é considerado, pelo diretor de TI, bom e estável. Mas, ele ressalta, "um bom ERP é aquele que você sabe utilizar e tem aderência ao seu negócio. Acredito que este ERP é bom para alguns segmentos”.

A empresa utiliza, ainda, partes de um WMS e um sistema de gerenciamento de rota adquiridos no mercado. Todas as demais aplicações utilizadas foram sendo desenvolvidas internamente, ao longo do tempo, pela equipe de TI e são capazes de atender às diferentes necessidades do negócio.

Estes módulos gravitam ao redor do ERP e foram denominados "Sistema Órbita". Dois servidores dão suporte ao ERP e, um servidor, ao Sistema Órbita. Os equipamentos são 
trocados a cada cinco anos e, no momento, está em construção um ambiente capaz de replicar todo o sistema em caso de pane.

O Sistema Órbita foi desenvolvido internamente, está disseminado em todas as áreas da empresa e contém vários módulos. Do ponto de vista do cliente, um dos módulos mais importantes é o "pedido via web". Criado em 2000 e implantado no início de 2001 experimentalmente em um restaurante de Belém do Pará, foi rapidamente aceito e incorporado pelos clientes: no início de 2002, 100\% das lojas da rede já tinham adotado a tecnologia.

Antes da sua implantação, os pedidos eram feitos por telefone. O OL 2 - fast-food mantinha cerca de 30 funcionários exclusivamente para receber os pedidos e transferir as informações. Os erros eram freqüentes e se propagavam pela cadeia gerando ineficiências. Atualmente, trabalham no recebimento de pedidos apenas dois funcionários e os erros praticamente inexistem.

No "pedido via web", os pontos de venda da rede podem fazer o pedido diretamente pela internet. O pedido é confrontado com a média do restaurante para aquele dia da semana (por exemplo, a média dos últimos cinco pedidos realizados às sextas-feiras). Se ocorrer distorção, o sistema emite um alerta de erro e pede uma confirmação.

O OL 2 - fast-food, por sua vez, mantém um sofisticado back-office onde são gerenciados os "pedidos via web”. Por exemplo:

- Mesmo depois da confirmação do cliente para um pedido fora do seu padrão habitual, o funcionário do OL 2 - fast-food telefona para mais uma confirmação.

- Caso o cliente ultrapasse o horário máximo para efetuar o pedido (11h10min), o sistema gera automaticamente um pedido baseado na média relativa.

- Os produtos da rede estão classificados em três famílias: congelados, refrigerados e secos. Ao realizar o pedido, automaticamente é gerada a informação do seu volume e, portanto, o espaço necessário no caminhão e na geladeira do cliente.

- Mesmo dentro da rede existem restaurantes com perfis diferentes. Alguns restaurantes têm café, outros não. Ou campanhas restritas somente a uma determinada área. O sistema é customizado para que o cliente acesse somente as informações que são relevantes para o seu negócio.

Encerrada a coleta dos pedidos, o sistema emite as notas fiscais e uma etiqueta para cada pedido. O faturamento do pedido será recebido pelo cliente depois de 48 horas. Já a entrega dos produtos depende da distância que será percorrida. 
As etiquetas contêm várias informações importantes e são fundamentais para o processo logístico. Dentre elas: código da loja, código do produto, localização do produto no armazém, rota do caminhão, lógica do carregamento e lógica da descarga.

Com as etiquetas referentes a cada rota, os funcionários começam a realizar a separação das mercadorias. Se o cliente de uma rota pediu duas caixas de pães, por exemplo, o funcionário terá duas etiquetas (1/2 e 2/2) que serão afixadas nas respectivas caixas. Com este procedimento, o índice de erro na separação dos produtos é inferior a $3 \%$.

Embora o WMS ofereça a possibilidade de utilização do código de barras para realizar a separação (picking) dos produtos, ele é utilizado, exclusivamente, para a contagem do inventário. A separação é feita por meio de etiquetas por serem mais eficientes: em uma medição o OL 2 - fast-food constatou que a utilização do código de barras aumentava o tempo de coleta em cerca de $30 \%$.

Encerrada a separação, as etiquetas vão indicar a melhor maneira de efetuar o carregamento do caminhão e a descarga das mercadorias nos pontos de venda. Por meio das etiquetas, o OL 2 - fast-food consegue, ainda, rastrear os pedidos em caso de reclamação da loja, controlando melhor todo o processo.

Quanto às tecnologias embarcadas, todos os caminhões são equipados com computador de bordo que registra os movimentos físicos do caminhão, tais como: freadas, velocidade, tempo de parada, etc. Além disto, o motorista recebe uma pasta padrão que contém todos os documentos necessários, termômetro para verificação das temperaturas, um celular e um Palmtop. O Palmtop está equipado com um software de gestão da rota que indica a rota a ser percorrida pelo caminhão.

O motorista alimenta o sistema com as informações de entrega em cada ponto de venda (número de caixas descarregadas, horário de chegada, de saída, etc.). As informações são endossadas pelo gerente da loja que assina virtualmente no Palmtop. O Palmtop capta, também, todas as informações do computador de bordo (via RS 232).

Ao retornar ao CE, o motorista deposita o Palmtop no "berço" onde as informações são descarregadas para um computador da empresa que irá alimentar o ERP. As informações serão processadas, analisadas e entrarão na composição das estatísticas.

A figura abaixo representa o fluxo de informação entre os pontos de venda da rede e o OL 2. 
Figura 24 - Fluxo de Informação de OL 2

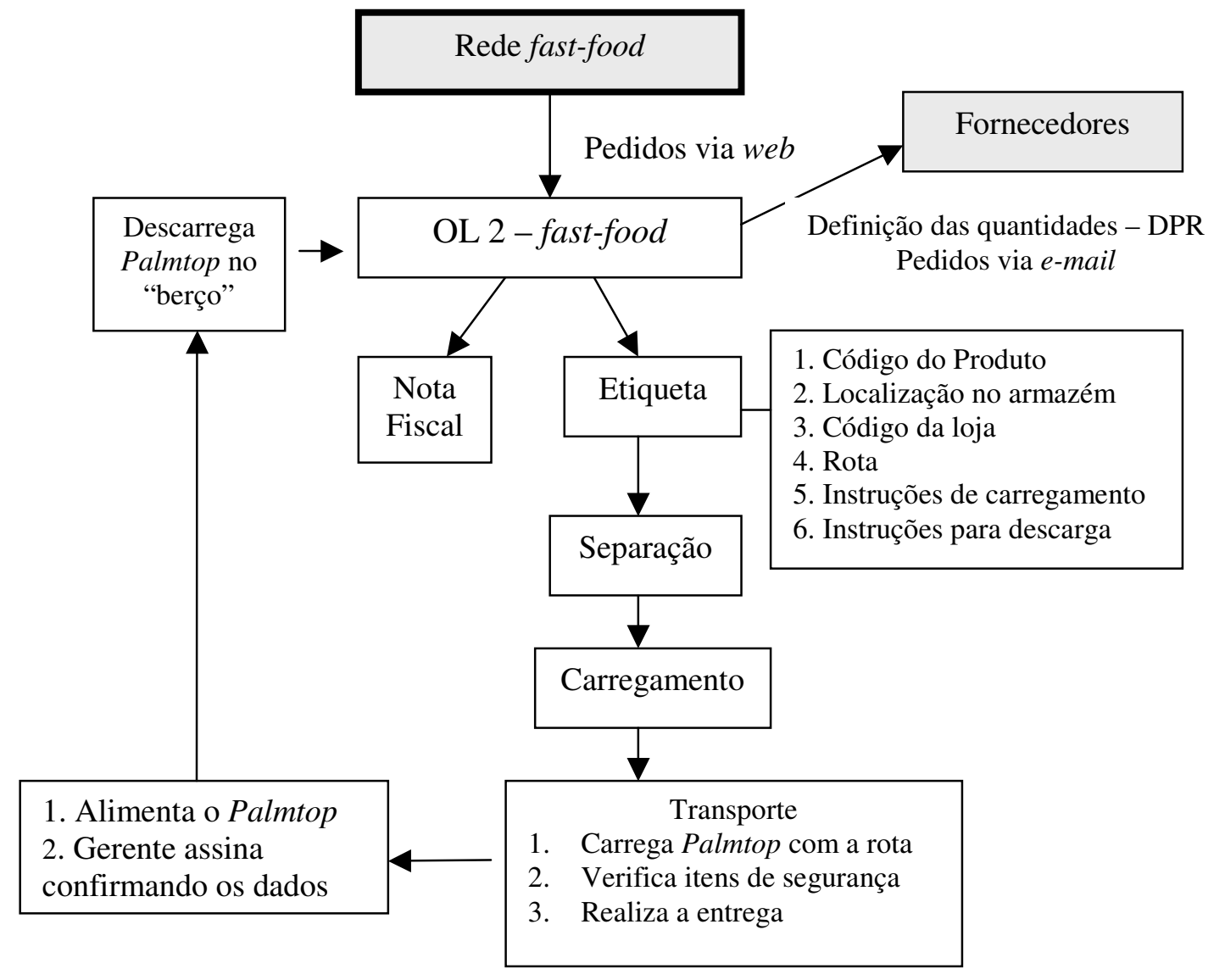

Fonte: executado pelo autor (2007).

Atualmente, o OL 2 está implantando um novo sistema em seus caminhões que utilizará a tecnologia Bluetooth. A tecnologia Bluetooth é um padrão para comunicação sem fio, realizada por meio de ondas de rádio, entre aparelhos eletrônicos como telefones celulares, Palmtops, computadores, impressoras, etc.

Esta tecnologia apresenta uma série de vantagens. O telefone celular e o Palmtop serão substituídos pelo Palm Treo 680, diminuindo o custo da pasta padrão de R \$ 8 mil para cerca de $\mathrm{R}$ \$ 2,5 mil. Além disto, todas as informações do caminhão passarão a ser coletadas em tempo real.

Outro módulo do Sistema Órbita que atende aos clientes é o "gerenciador de campanha". Por campanha entende-se o conjunto de brindes que são oferecidos, e que mudam a cada mês, junto com a compra de um dos produtos da rede. Antes da implantação do módulo, era muito comum ocorrer sobras de brindes em algumas lojas enquanto havia falta 
em outras. Atualmente, graças ao módulo, não existe mais sobra de brindes nos armazéns do OL 2.

O módulo gerenciador de campanha efetua o gerenciamento dos estoques das lojas e realiza a distribuição de acordo com as vendas efetivamente realizadas. Desta forma, é possível deslocar o estoque de uma loja, onde as vendas estão abaixo do esperado, para outra, onde a demanda está sendo superior a prevista.

O Sistema Órbita não está exclusivamente voltado para o atendimento ao cliente. Possui, também, o Distribution Requirement Planning (DPR), módulo que controla o fornecimento dos produtos para o OL 2. Por meio do DPR, o OL 2 é capaz de monitorar toda a cadeia: a empresa relaciona os tempos de produção e de entrega dos produtos pelo fornecedor com os pedidos das lojas e, desta forma, consegue girar seu estoque de forma adequada.

Com a previsibilidade oferecida pelo DPR, o OL 2 é capaz de colocar o pedido para seus fornecedores com até oito semanas de antecedência. Os pedidos são enviados por $e$ mail. Duas semanas antes da data de entrega, quando necessário, são efetuadas correções. $\mathrm{O}$ sistema funciona bem, mas não permite acesso direto dos fornecedores a estas informações. Para melhorar sua integração para trás (a montante) na cadeia, o OL 2 está desenvolvendo um Vendor Management Inventory (VMI).

Quando estiver implantado, o VMI dará aos fornecedores informações sobre os estoques, a demanda e o consumo efetivo nas lojas. A partir daí, os fornecedores poderão decidir o volume de sua produção com maior precisão e realizar o reabastecimento do OL 2 sem a necessidade da realização dos pedidos. Os fornecedores gerenciarão os estoques do OL 2.

Segundo o entrevistado, a TI vem contribuindo com diminuição de custo, aumento da qualidade, melhoria no desempenho, melhor gerenciamento, etc. Em um quadro disponibilizado na entrada dos depósitos de OL 2 é possível constatar os resultados: $96 \%$ de confiabilidade na entrega (acerto nos pedidos) e 100\% de confiabilidade na distribuição (pontualidade), entre outras informações. Enquanto isto, os gastos com TI no ano de 2006 representaram apenas $0,8 \%$ do faturamento líquido da empresa.

O diretor de TI conclui: além de melhorar o desempenho e reduzir custos, a TI vem contribuindo para o crescimento da empresa: além de novos mercados, a empresa vem também ocupando mercados dos concorrentes. Há dois anos atrás passou a atender os restaurantes da rede na América Latina e Central, onde foi implantado o ERP com vários 
módulos do Sistema Órbita. O pedido via web, por exemplo, já está em operação em Porto Rico, no Panamá, Costa Rica e Guatemala com resultados bastante satisfatórios.

Atualmente, a TI ocupa uma diretoria e está subordinada diretamente à presidência do OL 2 - fast-food. Além do diretor, trabalham na área nove funcionários.

\subsubsection{Análise do papel da TI no apoio às atividades desenvolvidas}

As tecnologias utilizadas nas atividades logísticas serão analisadas a partir do posicionamento estratégico do operador, por meio da perspectiva interna e do mercado atendido (BERGLUND, 1997).

\section{Com relação à perspectiva interna:}

OL 2 caracteriza-se como um grande operador que desenvolve soluções logísticas completas para um único cliente: a RFF. O operador vem buscando oferecer novos serviços e realizar suas atividades de novas formas.

OL 2 desenvolveu suas operações com o objetivo central de atender as necessidades logísticas de seu cliente. Portanto, todas as tecnologias que utiliza estão voltadas para a execução eficiente e eficaz das suas operações. Utiliza em seu processo um sistema ERP, partes de um WMS, além das tecnologias embarcadas nos caminhões. Mas seu diferencial é dado pelo "Sistema Órbita", desenvolvido especialmente para atender as características de seu cliente.

Os módulos do "Sistema Órbita" e as tecnologias embarcadas nos caminhões vêm permitindo: rapidez no atendimento ao seu cliente; diminuição nos atrasos e erros na entrega e no recebimento dos pedidos; diminuição nos níveis de estoque; eficiência na movimentação dos produtos; diminuição dos custos logísticos e melhora na qualidade do serviço; apoio ao ciclo de vida dos produtos e, sobretudo, o oferecimento de serviços diferenciados facilitando o processo de agregação de valor.

OL 2 tem como metas ter flexibilidade para explorar novas oportunidades e adicionar o máximo de valor ao processo logístico por meio da gestão eficiente e eficaz dos fluxos e estoques. A TI vem contribuindo para a criação, circulação e difusão das informações entre OL 2, seu cliente, as lojas da rede e, em menor grau, com os fornecedores; possibilitando um maior controle e a inovação nos processos logísticos e facilitando a coordenação. A TI tem, portanto, papel central (BOWERSOX; DAUGHERTY, 1995; HENDERSON; VENKATRAMAN, 1993). 
Mas, para que a TI contribua para a competitividade do processo logístico é necessário haver alinhamento entre a estratégia do negócio e da tecnologia (HENDERSON; VENKATRAMAN, 1993). No caso de OL 2, a estratégia do negócio determinou a estratégia de TI adotada pela empresa e que, por sua vez, exigiu o estabelecimento de infra-estrutura de TI e processos adequados. O "Sistema Órbita" foi desenvolvido por OL 2 com o objetivo de apoiar a estratégia de desenvolvimento integral do processo logístico de seu cliente.

OL 2 enquadra-se, portanto, no alinhamento denominado por Henderson e Venkatraman (1993) de "Transformação Tecnológica". Há a busca por tecnologias que viabilizem a estratégia do negócio. Neste alinhamento estratégico, a TI pode ser avaliada pelo que adicionou ao produto ou serviço final da empresa. No caso de OL 2 permitiu o desenvolvimento do processo logístico de seu cliente de modo mais eficiente e eficaz.

Finalmente, analisando a importância das aplicações de TI presentes e futuras para o OL 2 pode-se concluir que os desenvolvimentos do "Sistema Órbita" contribuem decisivamente para o seu sucesso na medida em que dão suporte integral ao processo logístico do seu cliente. O operador apresenta, portanto, elevada "necessidade de TI confiável”.

Estão previstas, ainda, atualizações neste sistema, com a incorporação de novos módulos capazes de proporcionar integração com os fornecedores. O operador apresenta, também, necessidade de novas aplicações de TI. Portanto, OL 2 está enquadrado no quadrante "Estratégico" (NOLAN; MCFARLAN, 2005). As aplicações de TI tem elevada importância estratégica para OL 2.

\section{Com relação à perspectiva do mercado atendido:}

OL 2 opera somente no setor de alimentos atendendo a um único cliente, atua nos ciclos de distribuição e de suprimentos; procura por meio da TI oferecer um serviço diferenciado e de qualidade elevada, e o escopo geográfico do operador assim como as atividades e serviços que oferece estão adequados as necessidades de seu cliente. O "Sistema Órbita" permite ao operador e ao cliente controle total dos processos, oferecendo informações atualizadas.

Quanto as necessidades logísticas de seus clientes:

- Seu único cliente é uma grande rede com mais de mil pontos de venda distribuídos em 134 cidades do Brasil e que opera com alimentos perecíveis, o que exige rapidez na entrega. O processo logístico desenvolvido por OL 2 é, portanto, bastante complexo e exige a utilização de tecnologia. O "Sistema Órbita" foi desenvolvido para atender as 
particularidades de seu cliente, mas não existem elementos no estudo de caso que permitam analisar o papel da TI em diferentes setores (BOWERSOX; CLOSS, 2001).

- OL 2 não atua no ciclo de apoio à manufatura, ou logística interna, já que atende exclusivamente a uma rede de lanchonetes e, portanto, não há elementos para confirmar ou refutar a proposição relativa à política de produção (BOWERSOX; CLOSS, 2001; PORTER; MILLAR, 1985).

\subsubsection{TI e a gestão integrada da logística}

Quanto a gestão integrada da logística e ao estabelecimento das redes de valor, os desenvolvimentos do sistema órbita garantem uma boa integração do OL 2 - fast-food com seu cliente, a RFF e com os clientes de seu cliente, as lojas da rede. RFF recebe um espelho de todas as notas fiscais emitidas e pode, desta forma, controlar seus estoques. E as lojas colocam seus pedidos diretamente nos servidores de OL 2.

O nível de integração com os fornecedores é menor. A troca de informação é realizada por e-mail e, atualmente, o único módulo do "Sistema Órbita" voltado para os fornecedores é o DPR (Planejamento das Necessidades de Distribuição). Mas, o DPR não permite acesso direto dos fornecedores aos estoques de OL 2. O nível de integração a montante na cadeia irá melhorar com o desenvolvimento do VMI (Estoque Administrado pelo Fornecedor).

Assim, os desenvolvimentos do "Sistema Órbita" vêm priorizando a integração no ciclo de suprimentos, embora o operador pretenda melhorar, no curto prazo, a integração no ciclo de distribuição. A cadeia de suprimentos gerenciada por OL 2, portanto, não está plenamente integrada (COOPER; LAMBERT; PAGH, 1997; STEVENS, 1989).

Com relação à coordenação, OL 2 é responsável pela sincronização dos fluxos entre os parceiros, estabelecendo parâmetros e regulamentações que devem ser seguidos pelos agentes, tais como codificação de materiais e produtos. Apesar do seu importante papel na coordenação da cadeia, cabe à rede fast-food determinar de que forma os agentes irão interagir.

Finalmente, dada à estratégia da rede fast-food, as parcerias estão no fundamento de operação da cadeia de suprimentos. Elas são motivadas, sobretudo, pela configuração complementar (BRITTO, 2002), e são fortemente estabelecidas de modo que cada empresa vê o outro como uma extensão de seu negócio (LAMBERT; EMMELHAINZ; GARDNER, 1996). OL 2, assim como grande parte dos fornecedores, atende exclusivamente à rede fastfood e está tão intrinsecamente ligada à ela que o contrato de prestação de serviço é verbal. 
Assim, a integração é total com o cliente e com os clientes dos clientes (as lojas da rede fast food), e menor com aos fornecedores. Na classificação proposta por Venkatraman (1994) OL 2 pode ser enquadrado no nível de "redefinição do escopo do negócio". Isto porque, embora não plenamente integrado a todos os agentes, as aplicações de TI vem permitindo a eliminação e/ou reestruturação das tarefas, e alterando a distribuição dos lucros.

Além disto, os fluxos estão sincronizados, e existe forte relação de confiança, metas comuns e compatibilidade técnica entre os agentes. Portanto, estão postos os fundamentos para a logística integrada (BOWERSOX; CLOSS; STANK, 1999; BERGLUND, 1999; CHOPRA; MEINDL, 2001; BOWERSOX; CLOSS; STANK, 1999).

De fato, OL 2 estabelece uma estrutura de rede eficiente, alinhando os processos operacionais de várias empresas, dentro de um sistema de cadeias de suprimentos integradas (LEWIS; TALALAYEVSKY, 2000). A dinâmica da cadeia é dada pela expectativa de venda (push), com os estoques sendo reabastecidos continuamente (continuous replenishment) (TURBAN; RAINER; POTTER, 2003).

A estrutura que resulta desta forma de operar pode ser classificada como rede de empresas. Mas, mais ainda, está próxima de uma rede de valor. Nesta rede, os fluxos e estoques de matérias, serviços e informação são administrados como um processo contínuo. E, para isto, os agentes operam de forma colaborativa e ocorre um nível elevado de integração, compartilhando grande parte das informações (BOVET; MARTHA, 2001). 


\section{OPERADOR LOGÍSTICO 3}

\subsection{Caracterização do operador logístico 3 (OL 3)}

O operador logístico 3 (OL 3) é subsidiária de uma empresa norte-americana que possui cerca de 300 centros de distribuição e 20 mil colaboradores em todo o mundo.

A empresa iniciou suas atividades no Brasil em 1998, quando foi convidada por uma grande empresa brasileira de importação e exportação para formar uma joint venture. $\mathrm{Na}$ época, o governo brasileiro promoveu uma forte abertura dos mercados e houve grande aumento no volume das importações, sobretudo de automóveis. Os automóveis chegavam pelo porto de Vitória e, a partir daí, tinham que ser distribuídos para os diversos pontos do país.

A empresa brasileira era responsável por $80 \%$ de toda a importação do país e prestava serviços para a Volkswagen. Tinha tradição no comércio exterior, mas não em operações logísticas, e os serviços logísticos estavam ficando tão ou mais importantes que o negócio de importação e exportação. A saída encontrada foi buscar um parceiro experiente na área logística. Nasceu, assim, o OL 3.

Em janeiro de 1999, OL 3 executou sua primeira operação: transferiu o centro de distribuição de uma grande montadora, que funcionava em São Bernardo do Campo, para Barueri e passa a operá-lo. Em julho do mesmo ano começou a operar o centro de distribuição de uma grande rede de supermercados. Em seguida vieram empresas do setor eletroeletrônico e, depois, varejo.

Em 2005, a trading deixou o negócio e a OL 3 assumiu integralmente a operação da empresa. Atualmente, OL 3 atua em diversos setores, mas ainda está bastante focada nos setores automotivo, eletroeletrônico e de consumo.

OL 3 do Brasil atende todo o território nacional e é o centro de operações para a América do Sul. Opera com cerca de 1500 funcionários e 14 centros de distribuição. Destes, 11 estão localizados no Estado de São Paulo e, os outros três, no Paraná, Minas Gerais e Bahia.

Até 2002, OL 3 operava exclusivamente com armazenagem. Iniciou suas atividades de transporte a partir da demanda de um fabricante de equipamentos eletrônicos para que gerenciasse a distribuição de seus produtos. Atualmente, gerencia mais de 600 veículos, mas toda sua frota é terceirizada. As transportadoras são parceiros exclusivos. 


\subsubsection{Processo logístico e atividades de OL 3}

OL 3 atua na armazenagem, e na gestão do transporte e da cadeia de suprimentos. Desenvolve, também, logística interna, gerenciando materiais produtivos e não produtivos e abastecendo linhas de montagem. Assim, pode atuar em toda a cadeia logística, desde o recolhimento dos materiais e produtos nos fornecedores de seus clientes, até a entrega dos produtos finais nos pontos de venda.

O OL 3 atua no ciclo de distribuição, ou logística de saída dos clientes; transportando seus produtos para os pontos de venda (clientes A, C, D, E, F). Em um único caso, opera no ciclo de suprimentos, ou logística de entrada, transportando os produtos dos fornecedores para abastecimento do CD de seu cliente B.

Entre uma ponta e outra do processo logístico, os materiais e produtos transportados são armazenados nos CDs de OL 3. No ciclo de apoio à manufatura ou logística interna, OL 3 opera dentro das fábricas alimentando a linha de produção, expedindo os produtos acabados e controlando o inventário (BOWERSOX; CLOSS, 2001; PORTER; MILLAR, 1985).

Seus principais fornecedores são as empresas transportadoras. Já, quanto aos clientes, estão concentrados nos setores automotivos e de eletroeletrônicos. Destacam-se duas grandes montadoras (A e B) e quatro importantes fabricantes de equipamentos eletrônicos $(C, D, E$, F).

A figura abaixo representa, de forma simplificada, o processo logístico desenvolvido pelo OL 3 com estes clientes. 
Figura 25 - Fluxos de materiais e produtos de OL 3

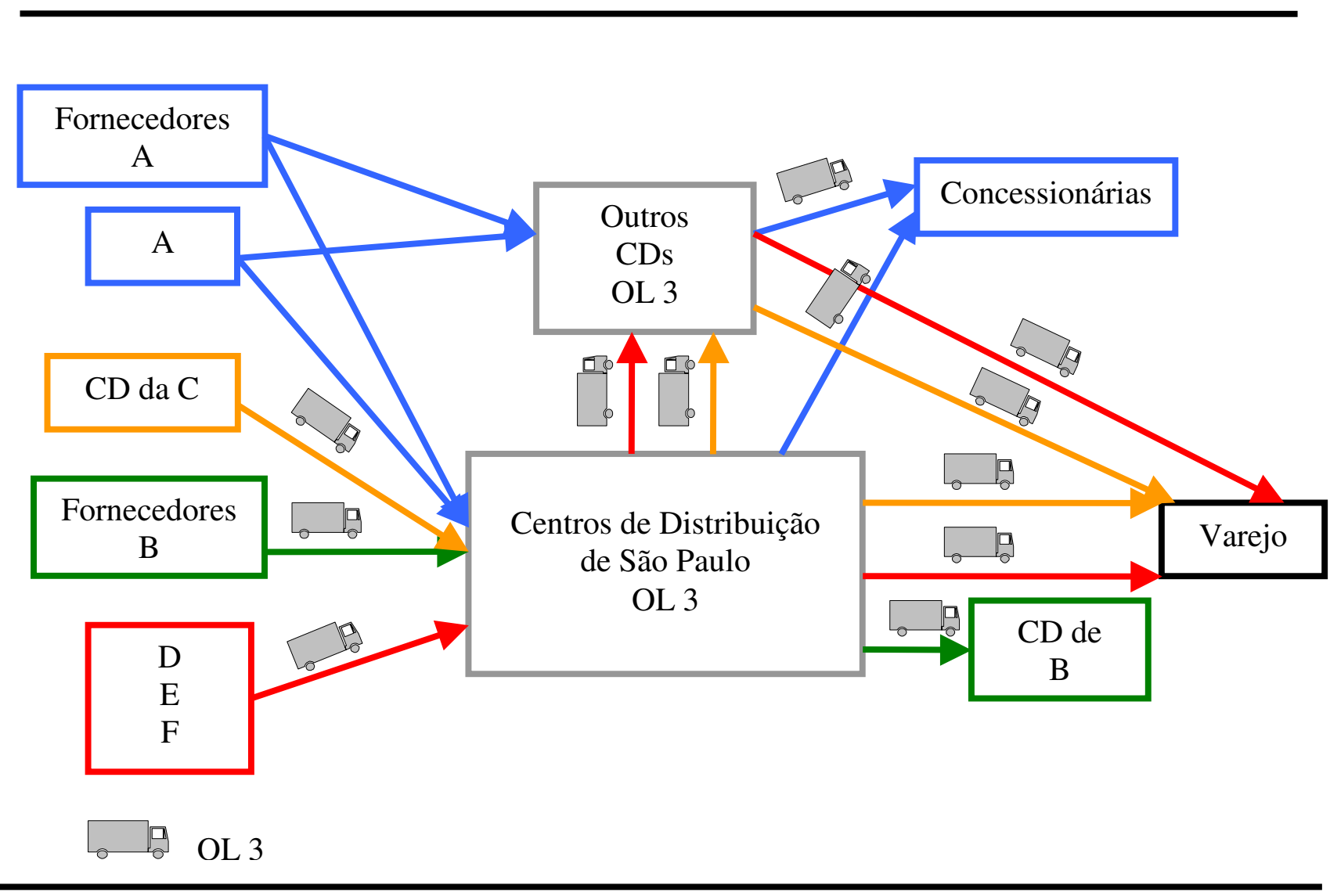

Fonte: adaptado de material disponibilizado por OL 3 (2007).

Para cada cliente, OL 3 realiza diferentes atividades do processo logístico.

- A: executa o gerenciamento do serviço de distribuição de peças para as revendas e os distribuidores. Recebe as peças dos diversos fornecedores, e da própria A, em seus armazéns de São Paulo e da Bahia e, dos armazéns, distribui para as concessionárias de todo o país. Não realiza, portanto, a coleta junto aos fornecedores de A, limitando-se à distribuição a partir de seus CDs.

- B: foi contratada para reorganizar o fluxo da coleta implantando o milk-run. Assim, coleta as peças nos diversos fornecedores de B, armazena em seu CD de Barueri em São Paulo para, mais tarde, realizar a consolidação e transferência para os Centros de Distribuição de B localizados em Sorocaba e Mogi das Cruzes.

- C: administra todo o transporte, desde a fábrica até os pontos de venda para o cliente final. Recolhe os produtos no CD de C, localizado em Campinas, e transfere parte para os armazéns das transportadoras e parte para o seu CD em Barueri. Finalmente, os produtos são transferidos para CDs em outras regiões ou diretamente para os pontos de venda. 
- D, E, F: executa gerenciamento do armazém e transporte. Recebe, em seu armazém de Barueri, os produtos importados e os produzidos no Brasil. A partir daí são separados, consolidados e distribuídos para pontos de venda em todo o país.

OL 3 está, no momento, preparando-se para voltar a atender uma grande rede de varejo nacional (G). Entre 2000 e 2003, OL 3 operou a logística do recém lançado site de G, movimentando uma grande quantidade de itens e aumentando, de forma significativa, a complexidade do processo logístico.

OL 3 desenvolve, também, operações de logística interna. Seus principais clientes são dois fabricantes de autopeças e um produtor de pneus. Opera dentro das fábricas, recebendo a matéria-prima, realizando o armazenamento, a separação e o seqüenciamento, alimentando a linha de produção, expedindo os produtos acabados e, finalmente, controlando o inventário. OL 3 está capacitada, ainda, para desenvolver técnicas de gestão como just-in-time e kanbam.

\subsubsection{Fluxo de informação e TI no OL 3}

Até 1999, as tecnologias adotadas por OL 3 em suas operações eram código de barras e radiofreqüência. Estas tecnologias foram utilizadas, pela primeira vez, para contar os carros importados que ficavam em Vitória, Espírito Santo, aguardando a distribuição. E, embora o uso destas ferramentas tornasse a contagem dos produtos mais demorada, elas ofereciam, em contrapartida, um maior controle e acurácia dos estoques. Portanto, tornavam o processo logístico como um todo mais produtivo.

Em 1999, quando foi chamada para operar o centro de distribuição de um grande supermercado, ficou clara a necessidade de um sistema que controlasse todo o processo de armazenagem.

Naquela época existiam poucos WMS no mercado e nenhum atendia as necessidades da empresa. OL 3 contratou, então, uma Software House para desenvolver um programa “customizado", que cobrisse seus processos. O WMS desenvolvido permitiu que todas as atividades - armazenagem, separação, carregamento - passassem a ser realizadas automaticamente.

O WMS executa as seguintes funcionalidades: emissão de documentos, transferência física de estoque, separação, consolidação de pedidos, radiofreqüência, código de barras, monitoramento, Cross-docking, logística de entrada e de saída, emissão de relatórios, gestão de armazéns multi-clientes, gerenciamento de inventários pelos métodos LIFO (Last In, First Out) ou FIFO (First In, First Out). 
Segundo o diretor de operações e TI, as necessidades dos clientes podem afetar o layout do armazém. Para ajudar nesta tarefa existem ferramentas, como o software Arena, que simulam as operações internas e indicam a melhor organização. Após a definição do layout do armazém, basta estabelecer os parâmetros no WMS que ele passará a atuar no novo padrão.

O diretor conclui: as tecnologias e sistemas utilizados na operação dos armazéns são sempre os mesmos, independente das características do produto, dos clientes, da política de produção ou mesmo se a logística é interna ou externa. No abastecimento de linhas de produção, por exemplo, cada ponto de abastecimento pode ser visto como um cliente, permitindo a utilização do WMS. No caso de diferentes políticas de produção, o que muda é a freqüência de entrega: se trabalha com estoques menores, as entregas deverão ser mais freqüentes.

O WMS - com diversos aprimoramentos - continua em operação até hoje e está sendo adotado como padrão nos armazéns da empresa em todo o mundo e vem sendo utilizado no abastecimento de linhas de montagem, utilizando o conceito já existente de montagem de kit.

A empresa já vinha, também, sentindo a necessidade de implantar um sistema ERP. Depois de ampla pesquisa, adquiriu o ERP desenvolvido por uma empresa brasileira com sede em Curitiba.

Para o diretor de operações, os principais requisitos dos ERPs voltados para operadores logísticos são, sobretudo, o gerenciamento de toda a parte documental (pedidos de compra, notas fiscais, recibos de entrega, etc.). O ERP escolhido oferecia estas funcionalidades. Ao longo do tempo foram sendo agregadas outras funcionalidades e, hoje, o ERP está totalmente customizado.

Até 2002, OL 3 atuava exclusivamente na armazenagem. Neste ano, estabeleceu contrato com "C" para realização do transporte dos produtos de seu CD de Campinas para clientes em todo o Brasil. Contrataram uma transportadora e adquiriram, no mercado, um software para gerenciar o transporte: o TMS (Transportation Management System).

Dentre as funcionalidades executadas pelo TMS estão: controle do tempo de deslocamento, preço do frete, roteirização, rastreamento do veículo, programação de embarque, emissão de documentos, Call Center e interface com os demais sistemas.

Além da implantação de um sistema de gestão do transporte, ainda era necessário definir as tecnologias que seriam embarcadas nos caminhões e que garantiriam a segurança das cargas. Todos os caminhões são equipados com dois computadores:

- Um computador de bordo que controla a localização do caminhão: quando chega ao cliente, o motorista digita um código que é enviado à transportadora. 
- E, outro computador, que protege a carga por meio de um software denominado e-cargo.

O e-cargo é um software, adquirido no mercado, de controle e rastreamento de cargas e entregas. As informações são coletadas por meio de rastreadores que operam via satélite e, depois, consolidadas em uma tela. As informações coletadas são disparadas, automaticamente, para o cliente por e-mail, além de serem disponibilizadas na web. O e-cargo controla, ainda, o trajeto do caminhão, que devem seguir um percurso pré-definido, travando todo o sistema e a abertura das portas para descarga diante de qualquer alteração de rota.

As aplicações de OL 3 - ERP, WMS, TMS e Tracking - são suportadas por dois bancos de dados e utilizam linguagem de programação de quarta geração (4GL), a Power Builder. As tecnologias permitem que os sistemas sejam capazes de se adaptar a qualquer infraestrutura de rede e tenham flexibilidade para se integrar aos sistemas de seus clientes e fornecedores. A figura abaixo representa as diversas aplicações de OL 3.

Figura 26 - Sistemas de OL 3

Necessidades internas de OL 3

\begin{tabular}{|c|c|c|c|}
\hline ERP & WMS & TMS & $\begin{array}{l}\text { Tracking } \\
\text { E-Cargo }\end{array}$ \\
\hline \multicolumn{2}{|c|}{ Tecnologia de Banco de dados } & \multicolumn{2}{|c|}{$\begin{array}{c}\text { Linguagem de programação } \\
\text { 4GL - Power Builder }\end{array}$} \\
\hline
\end{tabular}

Necessidades externas dos clientes

Fonte: adaptado de material disponibilizado por OL 3 (2007).

As aplicações permitem que OL 3 desenvolva o processo logístico de forma integrada, estabelecendo um fluxo contínuo de informação com seus parceiros. Mas, por questões de segurança, toda a troca eletrônica de informação é realizada por uma concessionária de comunicação: uma empresa que oferece EDI em redes privadas (VPN) e, portanto, mais seguras. 
O fluxo de informação não é igual para todos os clientes mas, de modo geral, obedece as etapas representadas na figura abaixo.

\section{Figura 27 - Fluxo de informação de OL 3}

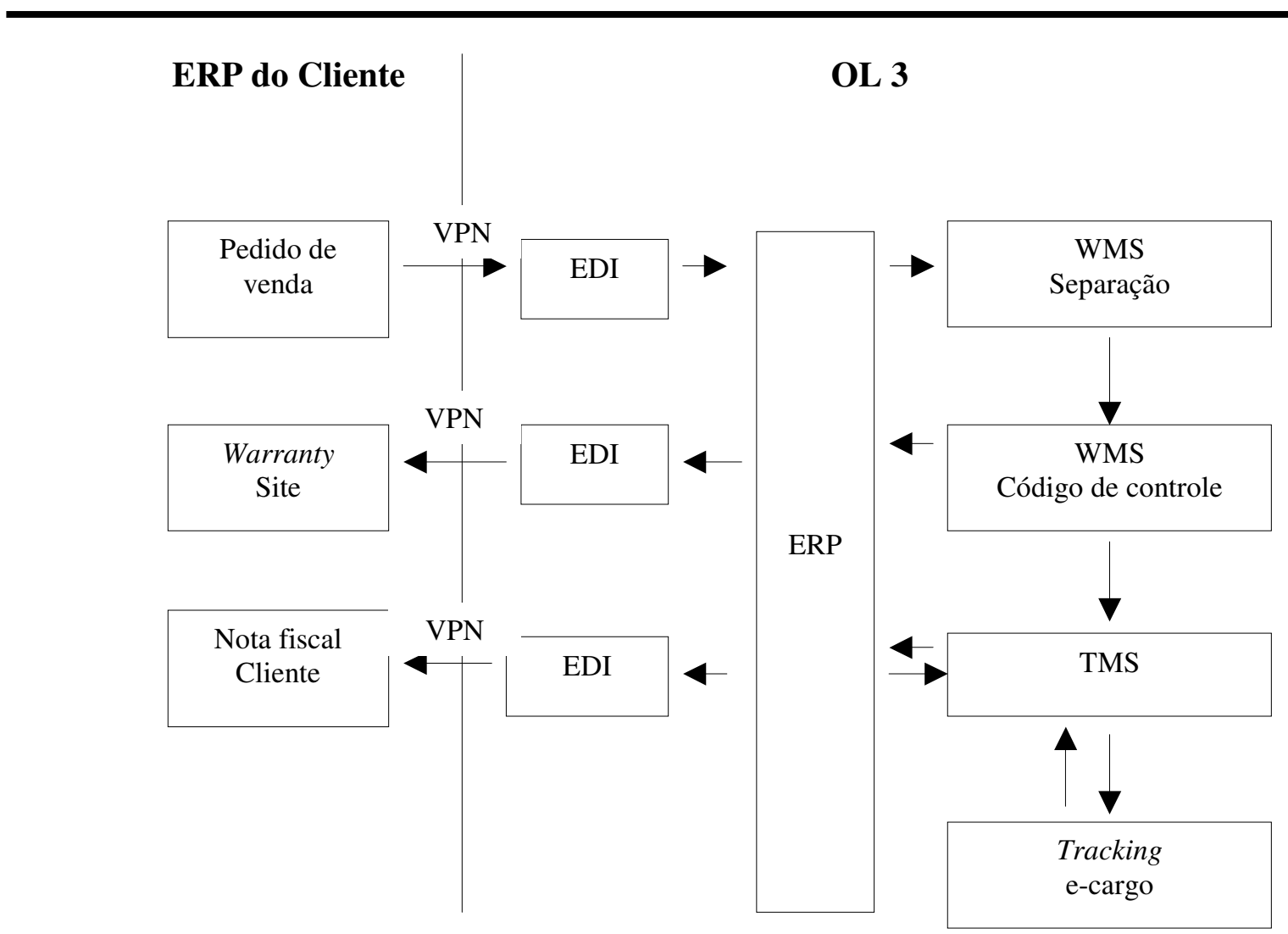

Fonte: adaptado de material disponibilizado por OL 3 (2007).

O fluxo tem início a partir da venda de algum produto. O ERP do cliente envia os dados da venda, via EDI, que é capturado pelo ERP de OL 3. Os dados são, então, enviados para o WMS, que emite a ordem de separação e um código de controle. O código de controle é remetido para o cliente que poderá, a partir dele, rastrear seus produtos.

O mesmo código de controle é enviado para o TMS. O TMS faz todo o gerenciamento da entrega e envia as informações para o sistema de rastreamento. O caminhão é carregado e o motorista vai, ao longo de seu percurso, alimentando o sistema. O TMS recebe os dados e disponibiliza no ERP de OL 3. E, finalmente, os clientes, por meio da internet, podem acessar o sistema e monitorar a entrega de seus produtos.

Atualmente OL 3 está implantando uma nova ferramenta. É um software com capacidade para consolidar cargas. O software analisa as entregas dos eletroeletrônicos das 
diversas marcas operadas por OL 3 e consolida em uma única caixa. OL 3 espera, com o uso do software, melhorar a rentabiliade.

Outra preocupação constante da empresa é com a segurança das cargas. Atualmente OL 3 faz o rastreamento do caminhão, mas não há controle da mercadoria que ele transporta. Já existe no mercado tecnologia capaz de rastrear individualmente os produtos transportados, mas é extremamente cara e, por esta razão, ainda não foi adotada.

Para o diretor de TI, operar eficientemente os armazéns e as transportadoras não traz vantagens competitivas para o operador logístico. As vantagens decorrem, sobretudo, da capacidade da empresa para desenvolver processos (métodos para cada tipo de operação) e das tecnologias utilizadas. Segundo ele, a informação que é oferecida ao cliente é mais importante do que a própria entrega, já que armazenagem e transporte são considerados commodities.

O uso da TI permite oferecer ao cliente um melhor gerenciamento do processo logístico, com uma acurácia do estoque de $99 \%$ e rapidez na entrega do produto. Já que o pagamento só é efetuado após a entrega, maior rapidez significa diminuição no tempo de recebimento. Mas o uso da TI vai além de melhorar o desempenho e reduzir custos: a TI vem contribuindo para o crescimento da empresa e o desenvolvimento de novos mercados.

Atualmente, a área de TI está diretamente subordinada à presidência da empresa e possui doze funcionários.

\subsubsection{Análise do papel da TI no apoio às atividades desenvolvidas}

As tecnologias utilizadas nas atividades logísticas serão analisadas a partir do posicionamento estratégico do operador, por meio da perspectiva interna e do mercado atendido (BERGLUND, 1997).

\section{Com relação à perspectiva interna:}

OL 3 desenvolve as atividades básicas do processo logístico (planejamento, estabelecimento e controle dos fluxos e estoques dos produtos, serviços e informação); compartilha seus recursos (armazéns e caminhões) entre os diversos clientes; está integrado verticalmente ao seus principais fornecedores, as transportadoras, focando nas atividades onde é mais competitivo; e é capaz de desenvolver os processos logísticos de seus clientes, inclusive considerando esta habilidade um diferencial importante (BERGLUND, 1997). 
OL 3 busca realizar suas atividades - armazenagem, gestão de transporte e da cadeia de suprimentos - de modo a obter o menor custo possível para o nível de serviço oferecido (excelência logística). Portanto, além de uma gestão eficiente dos fluxos e estoques; procura se diferenciar por meio do desenvolvimento de processos e da disponibilização das informações para seus clientes (BOWERSOX; CLOSS, 2001; BOWERSOX, CLOSS; STANK, 1999). Utiliza para apoiar suas operações sistemas ERP, WMS e TMS e um tracking para localização e proteção da carga.

OL 3 tem como metas atingir a flexibilidade sendo capaz de se adequar às mudanças nos mercados e aos diferentes clientes e adicionar o máximo de valor ao processo logístico por meio da gestão eficiente e eficaz dos fluxos e estoques. Os sistemas utilizados por OL 3 são capazes de se adaptar a qualquer infraestrutura de rede e, portanto, podem se integrar aos sistemas de seus clientes e fornecedores. O papel desempenhado pela TI é central (BOWERSOX; DAUGHERTY, 1995).

As tecnologias de informação vêm contribuindo para: minimizar eventos que perturbem o sistema, como atrasos ou erros na entrega dos produtos, no recebimento de pedidos, etc.; aumentar a eficiência no processo de transporte e armazenagem promovendo o compartilhamento de recursos, a racionalização das tarefas e a sincronização das atividades; apoiar a integração vertical e horizontal; e melhorar a segurança das cargas (GRAHAM; HARDAKER, 2000; BOWERSOX; CLOSS; STANK, 1999; STANK; KLEBER; CLOSS, 2001);

Mas, para que a TI contribua para a competitividade do processo logístico é necessário haver alinhamento entre a estratégia do negócio e da tecnologia (HENDERSON; VENKATRAMAN, 1993). No caso de OL 3, a estratégia do negócio determinou a estratégia de TI adotada pela empresa e que, por sua vez, exigiu o estabelecimento de infra-estrutura de TI e processos adequados.

OL 3 enquadra-se, portanto, no alinhamento denominado por Henderson e Venkatraman (1993) de “Transformação Tecnológica". Neste alinhamento estratégico, a TI pode ser avaliada pelo que adicionou ao produto ou serviço final da empresa. Como nos casos já citados, nota-se as buscas por tecnologias que viabilizem a estratégia do negócio.

Finalmente, analisando a importância das aplicações de TI presentes e futuras para o OL 3, pode-se concluir que seus sistemas de informação contribuem decisivamente para o seu sucesso na medida em que dão suporte integral ao processo logístico desenvolvido por OL 3. O operador tem elevada "necessidade de TI confiável". 
No momento OL 3 está implantando um sistema para consolidação das cargas e, no futuro, estão previstas a adoção de novos sistemas para melhorar a segurança. O operador tem necessidade de novas aplicações de TI. OL 3 pode ser enquadrado, portanto, no quadrante "Estratégico". As aplicações de TI têm importância elevada para OL 3 (NOLAN; MCFARLAN, 1984).

\section{Com relação à perspectiva do mercado atendido:}

OL 3 opera em poucos setores; desenvolve as atividades básicas nos três ciclos do processo logístico; contribui para uma maior eficiência logística de seus clientes por possuir capacidade física, equipamentos adequados e habilidade operacional; oferece dispositivos que melhoram a segurança no transporte; e se diferencia pelo desenvolvimento dos processos, pela qualidade dos serviços e acesso à informação. Os sistemas utilizados por OL 3 permitem o desenvolvimento do processo logístico de forma integrada, estabelecendo um fluxo contínuo de informação com seus parceiros.

Com relação ás necessidades logísticas de seus clientes:

- OL 3 emprega os mesmos sistemas para todos os clientes, qualquer que seja seu setor de atuação. As particularidades do setor podem exigir diferentes formas de organização das informações. Nestes casos, OL 3 customiza as interfaces, disponibilizando as informações no formato adequado.

- Com relação à política de produção, nos três clientes onde atua no ciclo de apoio à manufatura OL 3 utiliza as mesmas tecnologias (WMS). Para o diretor, a TI tem a mesma importância nas políticas de produção pull ou push. Para ele "o que pode mudar é o volume dos estoques operados pelo cliente: nas políticas de produção pull os estoques são menores e, conseqüentemente, a entrega dos materiais deve ser mais freqüente".

\subsubsection{TI e a gestão integrada da logística}

Quanto a gestão integrada do processo logístico e ao estabelecimento das redes de valor, OL 3 mantém um nível elevado de integração com seus clientes. As informações são enviadas, de forma geral, diretamente do ERP do cliente, via EDI, para o ERP de OL 3. Mas, OL 3 não está integrado com os clientes de seus clientes (caso de A, C, D, E, F) e nem com o fornecedor de seu cliente (caso de B).

O grau de integração de OL 3 com seus parceiros, as empresas de transporte, também é alto: todas as informações são enviadas automaticamente para o ERP do operador e, a partir 
daí, disponibilizadas para os clientes (BOWERSOX; CLOSS, 2001; BOWERSOX; DAUGHERTY, 1995; ASSUMPÇÃO, 2003; TURBAN; RAINER; POTTER, 2003).

A troca de informação com os clientes e realizada por meio de EDI sobre redes privadas (VPN) e, com as transportadoras, de forma automática. A integração com os clientes é facilitada por serem grandes empresas desenvolvidas tecnologicamente. Com as transportadoras, pelo fato de toda a tecnologia embarcada ser disponibilizada pelo OL 3 obedecendo, portanto, aos seus padrões.

OL 3 está, portanto, plenamente integrado aos seus clientes e aos seus fornecedores e parceiros, as empresas de transporte. Na classificação proposta por Venkatraman (1994), OL 3 pode ser enquadrado no nível de "estabelecimento da rede de negócio". Isto porque embora não esteja plenamente integrado a todos os agentes, os relacionamentos que mantêm garantem competências que permitirão produzir produtos e serviços superiores.

Com relação à coordenação, OL 3 não é responsável pela sincronização dos fluxos entre os agentes da cadeia, uma vez que somente recebe o comunicado de venda e realiza a entrega. O estabelecimento dos parâmetros e regulamentações que devem ser seguidos pelos agentes, tais como codificação de materiais e produtos, é determinado por seus clientes. OL 3 opera com uma codificação própria apenas para diferenciar os produtos dos clientes dentro do seu armazém.

Finalmente, seus principais parceiros são as empresas de transporte. As parcerias são motivadas, sobretudo, pela configuração aditiva (BRITTO, 2002), e são fortemente estabelecidas de modo que cada empresa vê o outro como uma extensão de seu negócio (LAMBERT; EMMELHAINZ; GARDNER, 1996).

Assim, no caso de OL 3, foi possível observar de forma parcial os fundamentos que permitem a integração logística: integração e coordenação das várias atividades e o estabelecimento de parceiras com agentes da rede (BOWERSOX; CLOSS; STANK, 1999; BERGLUND, 1999; CHOPRA; MEINDL, 2001).

Nos segmentos onde há integração logística, os fluxos e estoques de matérias, serviços e informação são administrados como um processo contínuo. Portanto, há o estabelecimento de uma rede de valor: os agentes operam de forma colaborativa e ocorre um nível elevado de integração, compartilhando grande parte das informações (BOVET; MARTHA, 2001). 


\section{OPERADOR LOGÍSTICO 4}

\subsection{Caracterização do operador logístico 4 (OL 4)}

O operador logístico 4 (OL 4) é líder mundial em correio expresso internacional, transporte terrestre, aéreo e marítimo, e serviços logísticos. Possui cerca de 500 mil funcionários em todo o mundo e sua rede internacional liga mais de 200 países. Seus serviços vão desde o envio de documentos por correio expresso até o gerenciamento total da cadeia de suprimentos.

A empresa foi fundada em 1969, em São Francisco nos EUA, e desde o início, operava com um novo conceito: enquanto as mercadorias e produtos seguiam de navio, os papéis necessários para o desembaraço aduaneiro eram remetidos por avião. Surgiu assim um novo serviço: correio expresso aéreo internacional.

Este procedimento diminuiu significativamente o tempo de espera das mercadorias no porto e possibilitou o rápido crescimento e expansão do OL 4. Em 1971, OL 4 passou a operar no Extremo Oriente e na região do Pacífico. Em seguida em diversos países da Europa, América Latina, África e Oriente Médio. Em 1988, eram 170 países.

Em 2002, OL 4 foi adquirida por um importante operador logístico da Alemanha (A) com presença mundial. "A" já vinha praticando clara estratégia de ampliação de escopo. Antes, já havia adquirido uma empresa suíça (B), líder mundial em frete aéreo e segunda maior em frete marítimo, e outra fornecedora de frete aéreo. Após a aquisição de OL 4, "A" comprou, ainda, uma empresa de correio expresso líder na Europa e uma empresa inglesa especializada em armazenagem e transporte doméstico.

"A" manteve a marca de OL 4 para todos os serviços logísticos, o que permitiu que a empresa se tornasse líder mundial em entregas expressas domésticas e internacionais, frete oceânico, correio e logística. No Brasil, OL 4 ocupou um espaço já criado por "B” que operava no mercado brasileiro desde junho de 1999.

Em 2003, OL 4 foi dividido em quatro unidades especializadas:

- OL 4 Express: oferece serviços de entrega de documentos e remessa urgentes em todo o mundo. Entre os serviços que realiza estão: "mesmo dia”, para encomendas que precisam estar em seu destino no menor tempo possível, "tempo definido", para encomendas com prazo reduzido de entrega, "import express", serviço internacional de coleta expressa e entrega porta a porta e vários outros serviços de valor agregado, tais como, soluções 
personalizadas, coletas e entregas especiais, serviço de liberação alfandegária, seguro, embalagem, manuseio, etc.

- OL 4 Global Forwarding: oferece serviços de transporte de mercadorias por via aérea e marítima. Atende, ainda, necessidades específicas com uma variedade de serviços de entrega com prazo definido. Opera com aviões próprios e de terceiros, mantendo contratos com cerca de 30 companhias aéreas. Dentre os serviços oferecidos estão: aeroporto a aeroporto, porta a porta, consolidação, carga fracionada, entrega rápida $24 \mathrm{X} 7$, prazo definido, transporte de cargas que exigem cuidados especiais como controle de temperatura, grandes dimensões, perigosas, etc., desembaraço aduaneiro e preparação de documentos.

- OL 4 Global Mail oferece serviços completos de correio internacional, marketing direto e soluções de publicação.

- OL 4 Supply Chain: atua no gerenciamento da cadeia de suprimentos buscando a otimização dos processos, redução tempo de entrega, visibilidade total da operação, rastreamento dos produtos, etc. Oferece serviços de armazenagem, mercadorias em trânsito, centros de distribuição dedicados e partilhados, milk-run, consolidação e desconsolidação, gerenciamento de transporte, gestão de estoque, atendimento da demanda, etc.

O estudo de caso foi realizado no OL 4 Supply Chain do Brasil. O OL 4 Supply Chain possui mais de 400 centros de distribuição e terminais localizados em cerca de 200 países. Possui centros de distribuição dedicados (utilizados por um único cliente) e compartilhados (utilizados por diversos clientes).

No Brasil, a empresa conta com cerca de 2 mil funcionários e possui 25 centros de distribuição (cerca de $300 \mathrm{mil} \mathrm{m}^{2}$ de área), dos quais treze estão localizados no Estado de São Paulo. Além disto, está capacitada para administrar armazéns, operando nas instalações dos clientes.

Os centros de distribuição são classificados em três tipos: Centros Multi-usuários, Centros Estratégicos de Peças (CEP) e Centros Expressos de Logística (CEL). Os Centros Multi-usuários operam com diversos clientes simultaneamente permitindo, desta forma, o compartilhamento do espaço, mão de obra, equipamentos e transporte e, consequentemente, redução de custos. Os CEP são instalações regionais com capacidade para atender rapidamente aos pedidos dos clientes. E, os CEL, são instalações regionais centralizadas capazes de realizar processamento dos pedidos e montagem customizadas. A empresa possui, ainda, centros de distribuição alfandegados, onde os produtos importados podem ficar 
armazenados antes do pagamento dos impostos e taxas, que são recolhidos somente no momento da distribuição.

$\mathrm{Na}$ distribuição, a empresa opera com uma frota com 15 mil veículos espalhados pelo mundo. No Brasil, todo o transporte terrestre é terceirizado para cerca de cem empresas transportadoras. O OL 4 é proprietário de quatro companhias aéreas sendo que, no Brasil, opera com aviões próprios e de terceiros. Terceiriza, também, serviço de frete marítimo.

\subsubsection{Processo logístico e atividades de OL 4 Supply Chain}

O OL 4 Supply Chain atua na armazenagem, e na gestão do transporte e da cadeia de suprimentos. Na logística interna opera gerenciando materiais produtivos e não produtivos e abastecendo linhas de montagem. Atua, também, na logística reversa.

É capaz de atuar, portanto, em toda a cadeia logística, desde o recolhimento dos materiais e produtos em seus clientes, até a entrega dos produtos finais nos pontos de venda. Opera nos ciclos de distribuição física, no ciclo de suprimentos e no ciclo de apoio à manufatura. Realiza, também, logística reversa.

O operador tem uma estratégia clara de diversificação, atendendo empresas de diversos setores, com diferentes portes e necessidades. OL 4 atende, em todo mundo, clientes de todos os tamanhos e com necessidades variadas. No Brasil não é diferente. Dentre seus clientes estão empresas do setor automotivo, químico e industrial, consumo e varejo, saúde e tecnologia. Seus principais fornecedores são as empresas transportadoras que prestam serviço de distribuição. As atividades executadas por OL 4 variam de acordo com o contrato estabelecido com cada cliente.

A figura 28 representa, de forma simplificada, o processo logístico desenvolvido pela OL 4 Supply Chain no Brasil. 
Figura 28 - Processo logístico do OL 4 Supply Chain

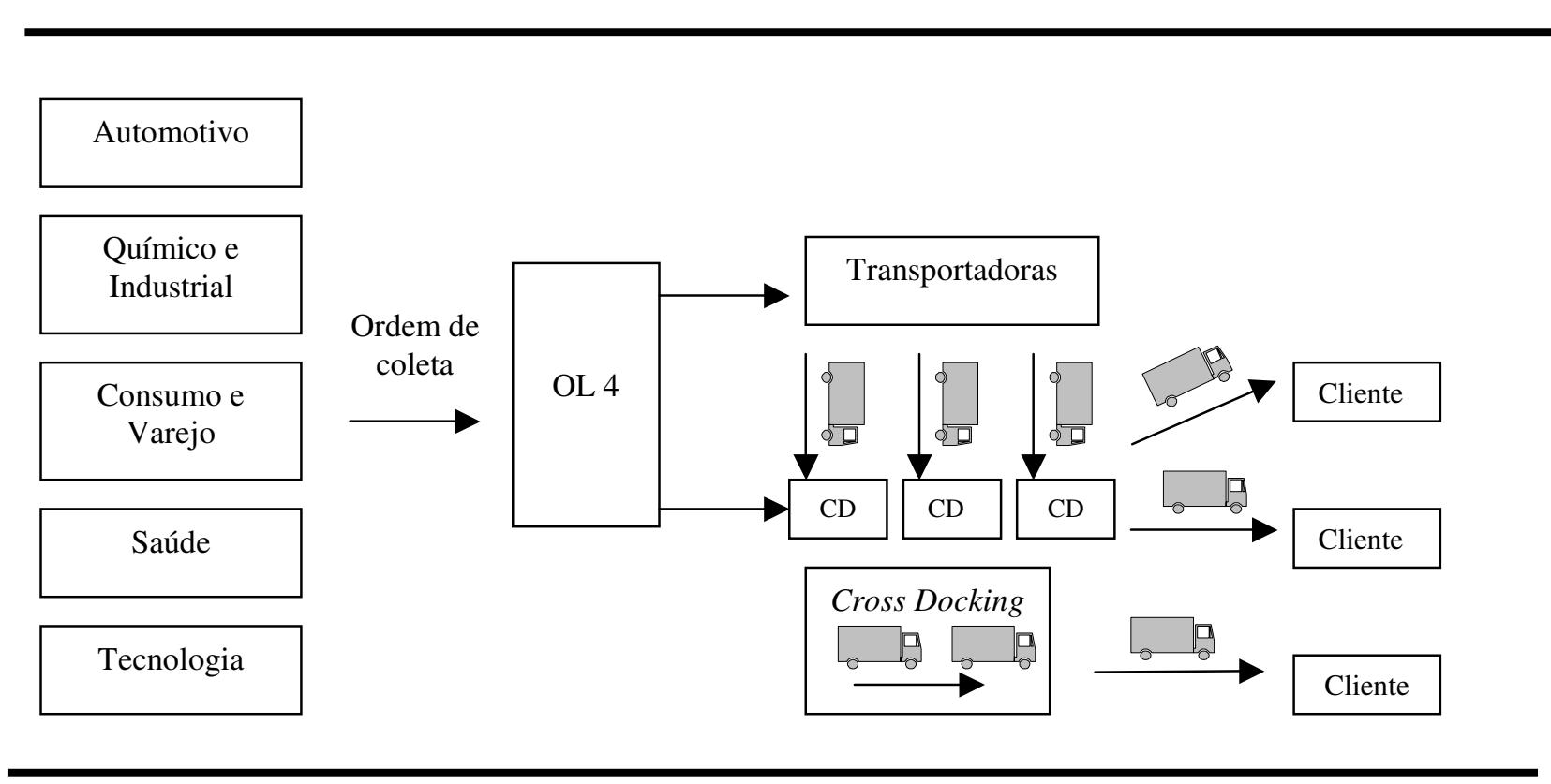

Fonte: executado pelo autor (2007).

O OL 4 recebe de seus clientes a ordem de coleta dos produtos. Localiza a mercadoria em seus próprios CDs, ou nos CDs de seus clientes, e dá inicio ao processo de separação dos produtos nos armazéns. A informação é, também, enviada para a transportadora que irá realizar a entrega.

A escolha da transportadora depende da carga e do contrato estabelecido com o cliente. Cargas de alto valor agregado, por exemplo, são direcionadas para transportadoras que disponham de tecnologias de segurança. As transportadoras têm, também, diferentes níveis tecnológicos. As mais avançadas podem trocar informações on line enquanto as menos desenvolvidas ainda utilizam telefone ou fax.

A transportadora envia o caminhão para o CD onde é carregado e segue para ser entregue aos clientes de seus clientes. O caminhão pode carregar produtos de um único cliente ou consolidar a carga de vários. O operador realiza, também, operação de Cross Docking. Neste caso, a carga é transferida entre os diferentes meios de transporte sem passar pela armazenagem.

O OL 4 opera, também, dentro das fábricas onde recebe a matéria-prima, realiza armazenagem, separação e seqüenciamento dos materiais, alimenta a linha de produção, distribui os produtos acabados e, finalmente, controla o inventário. Está capacitada, ainda, para desenvolver técnicas de gestão como just-in-time e kanbam. 


\subsubsection{Fluxo de informação e TI no OL 4 - Supply Chain}

Quando OL 4 começou a atuar no mercado brasileiro, em 2002, já utilizava em todo o mundo um sistema desenvolvido por uma Software House italiana denominado Projeto Logístico (PROLOGS).

O PROLOGS é um sistema de gerenciamento de armazém (WMS). Tem como função a operacionalização das atividades e o fluxo de informação no processo de armazenagem, registrando todos os eventos na recepção, manuseio e estocagem dos produtos. Possui os módulos: recebimento, conferência física, armazenagem, endereçamento dos produtos no estoque (código de barras), separação e distribuição. Indica, com precisão, a localização do produto no armazém. O endereçamento dos produtos nos estoque é controlado por uma etiqueta adesiva com código de barras. O código de barras é utilizado na contagem, controle do estoque e separação.

O PROLOGS é um sistema bastante versátil, com capacidade de se comunicar - via EDI - com o módulo de distribuição de diversos ERPs. Esta funcionalidade permite que os clientes possam gerar arquivos com as informações e enviar diretamente para os computadores do OL 4 ou, ainda, que OL 4 possa captar informações diretamente nos ERPs de seus clientes.

A transferência eletrônica de informação pode ser realizada de diversas maneiras, de acordo com a capacidade tecnológica e das regras do cliente. Os clientes podem ser notificados por e-mail, abaixar ou enviar arquivos pela web, realizar FTP passivo ou ativo, etc. Assim, segundo o entrevistado, OL 4 pode atender qualquer cliente, com qualquer nível tecnológico.

A adoção de um mesmo software em todo o mundo tem como objetivo a manutenção do padrão. Entretanto, dificulta o atendimento das particularidades dos clientes e dos mercados. O PROLOGS não atendia as necessidades fiscais e algumas características da armazenagem e distribuição do Brasil. Sua customização, entretanto, é um processo extremamente complexo: qualquer modificação no programa exige a aprovação da Software House, o que demanda tempo e o cumprimento de uma série de exigências.

A solução encontrada pelo operador foi manter em operação os sistemas herdados de B e desenvolver outros sistemas periféricos.

B havia adquirido um ERP que possuía um módulo de armazenagem. Este módulo executava apenas as atividades básicas e não atendia suas necessidades. O módulo de 
armazenagem sofreu, então, intenso processo de customização e foi praticamente reconstruído. Finalmente, em 1995, os sistemas foram separados nos módulos ERP e WMS.

A customização do WMS de B permitiu que o sistema fosse adequado às regras fiscais e às peculiaridades da logística no Brasil. E, por isto, é utilizado ainda hoje por cerca de $30 \%$ dos clientes de OL 4 que não se adaptaram ao PROLOGS. Um de seus maiores clientes, por exemplo, comercializa uma grande variedade de produtos, sendo que muitos não possuem código de barras (caso dos parafusos), dificultando a utilização do PROLOGS.

Quanto aos sistemas periféricos, OL 4 do Brasil desenvolveu o Sistema Fiscal Logístico (SFL) que gerencia e controla a parte fiscal dos clientes; e o sistema TMS que gerencia as operações de transporte, realizando cinco funções básicas: controle trafego interno de veículos nos CDs, cálculo de frete, conhecimento de embarque (CTRC), aviso de ocorrências e emissão de documentos de cobrança.

O TMS está em operação desde 2002 e, segundo a empresa, precisa ser atualizado. No momento, OL 4 está decidindo se compra um programa no mercado ou se desenvolve um aplicativo: os softwares de mercado não atendem plenamente suas necessidades. Uma hipótese considerada é comprar um TMS com boas funcionalidades e adequá-lo a seus processos.

Operando com estes sistemas, o fluxo de informação obedece, de forma geral, as seguintes etapas: 
Figura 29 - Fluxo de informação do OL 4 Supply Chain

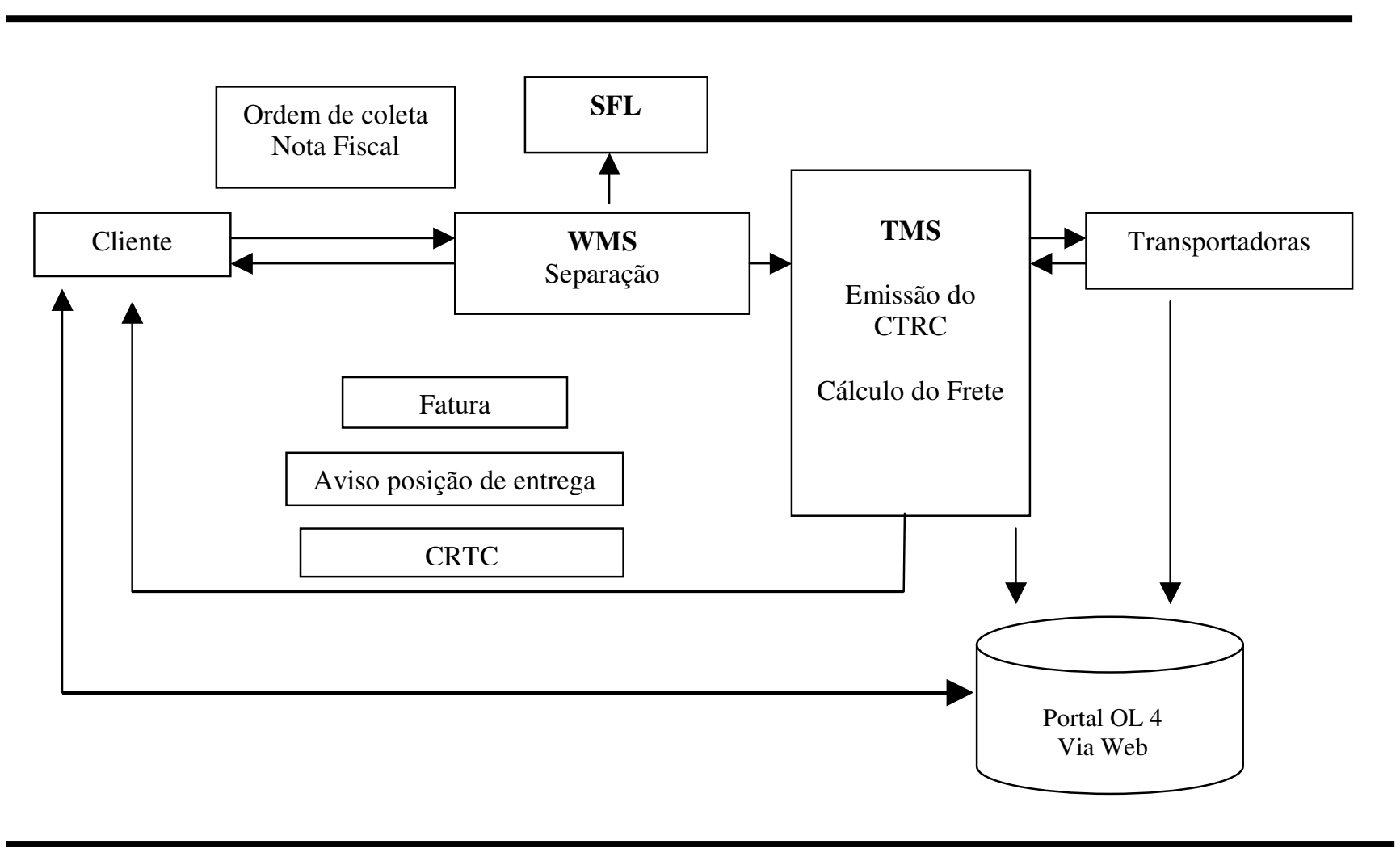

Fonte: adaptado partir material disponibilizado por OL 4 (2007).

O ERP do cliente envia a ordem de coleta e as informações da nota fiscal, via EDI, para o WMS do OL 4, ou OL 4 capta as informações diretamente no ERP dos clientes. Quando não ocorre este tipo de integração, as informações podem ser enviadas por e-mail, ftp, ou qualquer outro meio que o cliente disponha. O WMS emite uma ordem para separação dos produtos e envia a informação para o TMS e para o SFL.

Com as informações contidas na nota fiscal, o TMS calcula o frete e emite o conhecimento de embarque. Conhecimento de embarque é um documento emitido pela transportadora que atesta o recebimento da carga, as condições de transporte e o compromisso de entrega das mercadorias no destino pré-estabelecido.

Simultaneamente, o operador seleciona a transportadora e envia, quando possível de forma automática, aviso para o recolhimento da carga. O sistema também remete para os clientes e para as transportadoras o conhecimento de embarque (CRTC), avisos automáticos sobre qualquer ocorrência e, finalmente, após a entrega do produto, o documento de cobrança.

O TMS alimenta o banco de dados de OL 4 com as informações que são disponibilizadas no seu portal na internet. Dentre as informações, estão, por exemplo, a localização exata das remessas em tempo real. Estas informações podem, também, ser 
enviadas por fax, telefone ou e-mail: o cliente envia uma mensagem eletrônica com os números dos registros de suas remessas (no máximo 50) e o programa retorna em poucos segundos. Desenvolvido pelo OL 4 mundial em 2004, o portal é considerado estratégico pela empresa.

Outro diferencial importante para a empresa é sua flexibilidade para atender clientes com diferentes níveis tecnológicos, desde os que utilizam as ferramentas mais avançadas até os menos desenvolvidos. Segundo o diretor de TI, "a empresa nunca perdeu um cliente por não ser capaz de se adequar às suas necessidades".

A empresa considera fundamental a segurança das informações: A integração dos dados e a abertura de seu firewall só podem ser realizadas nos EUA, na matriz da empresa. Quanto às redes, a empresa pode operar por meio de intermediários, por redes privadas ou utilizando a rede de seus clientes.

Para o diretor de TI, não há diferenças significativas nos processos logísticos nos diferentes setores. Pode haver variação na forma da operar. Por exemplo, o setor de fármacos exige cuidado especial no manuseio: os produtos têm alto valor agregado, tamanho reduzido, os prazos de validade são extremamente importantes, etc. Mas, o processo logístico e, portanto, as ferramentas de TI utilizadas são basicamente as mesmas.

Um fator importante para a geração de vantagens competitivas é o atendimento às particularidades dos clientes. Para isto, OL 4 utiliza as mesmas tecnologias, mas customiza algumas interfaces com as informações relevantes para cada cliente.

Outro fator fundamental, que pode diferenciar a empresa está na informação e, portanto, nas ferramentas de TI. A adoção das tecnologias colabora para que a empresa ganhe novos clientes e atinja novos mercados. Mais ainda, o operador é um disseminador de tecnologia, sobretudo para seus fornecedores, as empresas de transporte.

Atualmente, cerca de 50 pessoas trabalham na área de TI que, no Brasil, está diretamente subordinada à presidência.

\subsubsection{Análise do papel da TI no apoio às atividades desenvolvidas}

As tecnologias utilizadas nas atividades logísticas serão analisadas a partir do posicionamento estratégico do operador, por meio da perspectiva interna e do mercado atendido (BERGLUND, 1997). 
Com relação à perspectiva interna:

OL 4 desenvolve todos os serviços e atividades do processo logístico, está capacitado para desenvolver soluções logísticas completas e serviços customizados e de se adequar a diferentes parceiros com objetivos estratégicos e estruturas organizacionais variadas (flexibilidade).

OL 4 busca operar os armazéns e administrar as transportadoras de modo a obter o menor custo possível para o nível de serviço oferecido (excelência logística). Portanto, procura administrar de forma eficiente os fluxos e estoques de materiais e produtos e oferecer diferenciais para seus clientes (BOWERSOX; CLOSS, 2001; BOWERSOX; CLOSS; STANK, 1999).

Nas atividades de armazenagem, OL 4 utiliza o WMS PROLOGS adotado mundialmente e um antigo WMS herdado de uma de suas empresas. As atividades de gestão do transporte e da parte documental são realizadas por dois sistemas periféricos, TMS e SFL.

O OL 4 visa, sobretudo, atender adequadamente seus clientes, adicionando o máximo de valor ao processo logístico, e atingir a flexibilidade, sendo capaz de se adequar às mudanças nos mercados e aos seus inúmeros clientes, com diferentes portes e necessidades. Além da gestão eficiente dos fluxos e estoques, OL 4 procura se diferenciar por meio do desenvolvimento de processos e disponibilizando as informações para seus clientes (BOWERSOX; CLOSS, 2001; BOWERSOX; CLOSS; STANK, 1999).

Capacidade para se adequar a diferentes situações e parceiros e diferenciação exigem intensa troca de informação e, portanto, no uso intensivo da TI. A TI vem contribuindo para a criação, circulação e difusão das informações entre OL 4 e seus clientes, possibilitando a customização e adaptação do operador aos diferentes clientes e oportunidades. A TI tem, portanto, papel central (NOLAN; MCFARLAN, 2005; BOWERSOX; DAUGHERTY, 1995).

As tecnologias de informação vêm contribuindo para: minimizar eventos que perturbem o sistema, como atrasos ou erros na entrega dos produtos, no recebimento de pedidos, etc.; aumentar a eficiência no processo de armazenagem e transporte promovendo o compartilhamento de recursos, a racionalização das tarefas e a sincronização das atividades (GRAHAM; HARDAKER, 2000; BOWERSOX; CLOSS; STANK, 1999; STANK; KLEBER; CLOSS, 2001).

Mas, para que a TI contribua para a competitividade do processo logístico é necessário haver alinhamento entre a estratégia do negócio e da tecnologia (HENDERSON; VENKATRAMAN, 1993). No caso de OL 4, a estratégia de TI foi determinada pela matriz da empresa, que adotou o mesmo software - WMS PROLOGS - em todo o mundo, 
obrigando o operador a manter em operação um WMS herdado de outra empresa e a desenvolver outros sistemas periféricos para atender as particularidades de seus clientes.

No caso de OL 4, a estratégia da TI exigiu o estabelecimento de uma nova estrutura de TI afetando, portanto, a estrutura de negócios existentes. As novas aplicações de TI têm como objetivo apenas cobrir as deficiências do sistema imposto pela matriz. Assim, OL 4 pode ser enquadrada na perspectiva de Nível de Serviço proposta por Henderson e Venkatraman (1993).

Finalmente, analisando a importância das aplicações de TI presentes e futuras para o operador logístico pode-se concluir que os sistemas de informação contribuem para o seu sucesso na medida em que, em conjunto, dão suporte integral ao processo logístico de OL 4. O operador tem elevada necessidade de TI confiável.

Está prevista a adoção de um novo sistema TMS que deverá ser customizado para se adequar ao PROLOGS: OL 4 não tem autonomia para realizar alterações no sistema PROLOGS. Mas, no horizonte de planejamento considerado pelos entrevistados, não foram identificadas pressões por novas aplicações de TI. OL 4 pode ser enquadrado, portanto, no quadrante "Fábrica" (NOLAN; MCFARLAN, 2005).

\section{Com relação à perspectiva do mercado atendido:}

OL 4 é capaz de operar com empresas de variados setores, desenvolvendo atividades em todos os ciclos do processo logístico. Seu diferencial está, principalmente, na capacidade de realizar operações logísticas para qualquer lugar do planeta, atendendo clientes de todos os tamanhos e com as mais variadas necessidades, e pela qualidade dos serviços e acesso à informação.

Com relação às necessidades logísticas dos clientes, de acordo com OL 4:

- Qualquer que seja o setor do cliente, o processo logístico é igual e envolve as mesmas atividades. Consequientemente utiliza as mesmas tecnologias. As características do setor podem resultar em particularidades que são atendidas por meio de customização das interfaces dos seus sistemas, disponibilizando as informações relevantes e no formato adequado para cada cliente.

- Com relação à política de produção, OL 4 utiliza a mesma tecnologia (WMS) em todos os clientes onde atua no ciclo de apoio à manufatura. Para o transportation leader, a TI tem a mesma importância nas políticas de produção pull ou push. 


\subsubsection{TI e a gestão integrada da logística}

Quanto a gestão integrada do processo logístico e ao estabelecimento das redes de valor, OL 4 mantém um nível de integração bastante variado com seus clientes e com seus fornecedores. O operador tem capacidade para estabelecer uma integração elevada, mas depende do desenvolvimento tecnológico dos outros agentes. Assim, OL 4 considera a flexibilidade como um diferencial importante, buscando se adequar às limitações de seus clientes e fornecedores.

O operador é capaz de trocar informações das mais variadas formas: por meio de EDI sobre redes privadas (VPN), por email, por ftp, por telefone, etc. No nível mais elevado, o fluxo de informação é estabelecido, via EDI, entre o ERP do cliente e o sistema PROLOGS. O WMS envia as informações diretamente para o TMS, que seleciona a transportadora, acompanha a entrega e alimenta o banco de dados. Todas as informações ficam disponíveis para os clientes no portal de OL 4 na internet.

OL 4 pode estar, portanto, plenamente integrado aos seus clientes e aos seus fornecedores, as empresas de transporte. Na classificação proposta por Venkatraman (1994), OL 4 pode ser enquadrado no nível de "estabelecimento da rede de negócio". Isto porque embora possa não estar plenamente integrado a todos os agentes, os relacionamentos que mantêm garantem competências que permitirão produzir produtos e serviços superiores.

Com relação à coordenação, OL 4 não estabelece a sincronização dos fluxos entre seus clientes e os clientes de seus clientes: apenas recebe o comunicado da venda e realiza a entrega. Os parâmetros e regulamentações que devem ser seguidos pelos agentes, tais como codificação de materiais e produtos são estabelecidos pelos clientes. E, mesmo no ciclo de apoio à manufatura, cabe a OL 4 apenas garantir o abastecimento contínuo das linhas de produção, estando a coordenação a cargo do cliente.

Finalmente, com relação ao estabelecimento de parcerias, os vínculos estabelecidos são muito variáveis. Com as empresas de transporte, as parcerias são motivadas, sobretudo, pela configuração aditiva (BRITTO, 2002). Mas é possível, diante de qualquer problema, dado o grande número de empresas que prestam este tipo de serviço para a OL 4, efetuar seu desligamento ou substituição. Desta forma, o grau de comprometimento é bastante variado e pode, em algumas circunstâncias, ser bastante frágil (LAMBERT; EMMELHAINZ; GARDNER, 1996).

Assim, no caso de OL 4, foi possível observar de forma parcial os fundamentos que permitem a integração logística: integração e coordenação das várias atividades e o 
estabelecimento de parceiras com agentes da rede (BOWERSOX; CLOSS; STANK, 1999; BERGLUND, 1999; CHOPRA; MEINDL, 2001).

Nos segmentos onde há integração logística, os fluxos e estoques de matérias, serviços e informação são administrados como um processo contínuo. Portanto, há o estabelecimento de uma rede de valor: os agentes operam de forma colaborativa e ocorre um nível elevado de integração, compartilhando grande parte das informações (BOVET; MARTHA, 2001). 


\section{OPERADOR LOGÍSTICO 5}

\subsection{Caracterização do operador logístico 5 (OL 5)}

O operador logístico 5 (OL 5) é uma das três empresas de um grupo nacional que atua na área de prestação de diferentes tipos de serviços. A primeira empresa, fundada em 1985, é especializada em manutenção e montagem industrial, e facilities. A segunda empresa, fundada em 1995, oferece serviços de apoio como manutenção, limpeza, pessoal administrativo e jardinagem. Finalmente, OL 5, fundada há sete anos, atua no gestão e operação da logística interna, de produção e movimentação, e na armazenagem. As três empresas complementamse e são, assim, capazes de atender qualquer necessidade de serviço de seus clientes.

O objetivo de OL 5 é desenvolver soluções logísticas por meio da análise das operações, da racionalização dos processos, e do estabelecimento de indicadores de desempenho que permitam avaliar o nível do serviço oferecido.

OL 5 atua nas regiões Sul e Sudeste e possui cerca de 2500 funcionários. Seu foco é o desenvolvimento do processo logístico interno e, portanto, suas atividades envolvem movimentação e armazenagem dentro das instalações das empresas (BOWERSOX; CLOSS, 2001). Assim, OL 5 não dispõem de armazéns e caminhões próprios para desenvolver o trabalho logístico. Opera os armazéns de seus clientes e, quando necessário, contrata meios de transporte.

O único armazém do grupo, situado em São Paulo, tem como função abastecer as três empresas com o material necessário para o desenvolvimento de suas atividades (limpeza, manutenção industrial, etc.). O armazém é utilizado, portanto, somente pelas empresas do grupo, e não atende aos clientes.

Recentemente, OL 5 comprou uma frota de 120 veículos para atender uma editora. Será a primeira atividade de logística externa que irá desenvolver.

\subsubsection{Processo logístico e atividades de OL 5}

OL 5 atua exclusivamente na logística interna ou, seu equivalente, no ciclo de apoio à manufatura das empresas. Há pouco tempo atrás foi contratado para sua primeira atividade externa: efetuar o transporte dos funcionários da editora “ $\mathrm{D}$ ” em eventos externos.

Suas atividades envolvem movimentação e armazenagem de produtos, materiais, componentes e peças semi-acabadas dentro das empresas. Assim, o trabalho logístico tem 
início no recebimento de materiais e componentes dos fornecedores e termina quando o produto está pronto para a venda.

Os fornecedores de OL 5 são, além de outros operadores logísticos, fornecedores e desenvolvedores de softwares. Seu principal parceiro é a Software House que desenvolveu a solução WMS adotada por OL 5 e que realiza as customizações quando necessário. E, finalmente, quanto aos clientes, atende cerca de trinta empresas de vários setores. Dentre eles: alimentos e bebidas; higiene e cosméticos; automotivo; informática e telecomunicação; alimentos, material mecânico; química e petroquímica; papel e celulose.

Para atender aos clientes, OL 5 desenvolveu uma metodologia, denominada "Gestão Estruturada da Logística" (GEL). A GEL subdivide o trabalho logístico interno em diversas áreas:

- Logística de compras e suprimentos que desenvolve e administra os fornecedores

- Logística de administração de materiais que realiza a programação, controle e recebimento dos materiais que serão utilizados no processo produtivo.

- Logística interna de produção que recebe, armazena, localiza, controla e abastece os processos produtivos com os materiais necessários; coleta o produto acabado e, quando necessário, embala.

- Logística de movimentação que gerencia todo o processo de movimentação interna e fornece os equipamentos adequados.

- Logística de distribuição que administra os armazéns: recebe, armazena, localiza e controla os produtos acabados; separa os pedidos e prepara a roteirização; e administra os meios de transporte.

- Finalmente, a área de consultoria e planejamento que avalia o processo, propõe soluções e realiza treinamentos visando racionalizar e melhorar as operações logísticas dos clientes.

Todas as áreas são avaliadas por meio de indicadores de desempenho e do nível de serviço oferecido aos clientes.

A figura abaixo representa, de forma simplificada, o processo logístico desenvolvido pelo OL 5 . 


\begin{tabular}{|c|c|c|c|c|}
\hline Suprimentos & & & & Distribuição \\
\hline $\begin{array}{l}\text { Desenvolver } \\
\text { fornecedores logísticos }\end{array}$ & Administração & & & de expedição e CDs \\
\hline $\begin{array}{l}\text { Administrar } \\
\text { modificacões técnicas }\end{array}$ & de materiais & Producã & & acabados \\
\hline nos fornecedores & Realizar planejamento & Receber, armazenar, & Movimentação & $\begin{array}{l}\text { Controlar quantidades e } \\
\text { volumes }\end{array}$ \\
\hline $\begin{array}{l}\text { Homologar amostras de } \\
\text { novos itens }\end{array}$ & $\begin{array}{l}\text { da necessidade de } \\
\text { materiais e produção }\end{array}$ & $\begin{array}{l}\text { localizar e controlar. } \\
\text { Realizar estoques }\end{array}$ & $\begin{array}{l}\text { Diagnosticar } \\
\text { processos de }\end{array}$ & $\begin{array}{l}\text { Armazenar, localizar e } \\
\text { controlar. }\end{array}$ \\
\hline $\begin{array}{l}\text { Elaborar contratos de } \\
\text { fornecimento }\end{array}$ & $\begin{array}{l}\text { Controlar processos } \\
\text { produtivos }\end{array}$ & $\begin{array}{l}\text { rotativos, } \\
\text { permanentes e }\end{array}$ & $\begin{array}{l}\text { movimentação } \\
\text { interna }\end{array}$ & Realizar estoques \\
\hline $\begin{array}{l}\text { Cadastrar itens novos no } \\
\text { sistema de materiais; }\end{array}$ & Necessidade de & $\begin{array}{l}\text { oficiais. } \\
\text { Abastecer processos }\end{array}$ & Prover equipamentos & oficiais; \\
\hline Gestão de kanbans de & $\begin{array}{l}\text { materiais e de } \\
\text { produção }\end{array}$ & & & $\begin{array}{l}\text { Realizar picking dos } \\
\text { pedidos }\end{array}$ \\
\hline $\begin{array}{l}\text { fornecedores } \\
\text { Logística reversa }\end{array}$ & $\begin{array}{l}\text { Controlar os processos } \\
\text { produtivos }\end{array}$ & $\begin{array}{l}\text { Montar kits e } \\
\text { subconjuntos }\end{array}$ & $\begin{array}{l}\text { manutenção } \\
\text { preventiva e corretiva }\end{array}$ & Preparar a roteirização \\
\hline $\begin{array}{l}\text { Milk-run } \\
\text { Embalagens } \\
\text { Auditar fornecedores }\end{array}$ & $\begin{array}{l}\text { Programar as remessas } \\
\text { dos fornecedores } \\
\text { Administrar os } \\
\text { estoques }\end{array}$ & $\begin{array}{l}\text { Coletar e inspecionar } \\
\text { produtos acabados } \\
\text { Embalagem unitária e } \\
\text { consolidada }\end{array}$ & $\begin{array}{l}\text { Controlar consumo } \\
\text { de combustível, } \\
\text { Realizar treinamento } \\
\text { operacional }\end{array}$ & $\begin{array}{l}\text { Administrar transportes } \\
\text { Administrar logística } \\
\text { reversa } \\
\text { Controlar fretes. }\end{array}$ \\
\hline
\end{tabular}

\section{Processo logístico interno}

Fonte: elaborado a partir de material disponibilizado no site <http://www.manserv.com.br> (2007).

As cinco áreas são independentes, mas podem ser integradas. Desta forma, OL 5 é capaz de desenvolver parte ou a totalidade das atividades logísticas internas de acordo com a necessidade dos clientes.

Abaixo estão descritas as atividades logísticas realizadas por OL 5 em alguns de seus clientes:

- Administra o armazém de uma distribuidora de gás "A". Recebe, armazena, localiza e controla os materiais, componentes e equipamentos; realiza a separação e entrega para os prestadores de serviço. Os prestadores de serviço são empresas terceirizadas que realizam consertos e trabalham na ampliação da rede de distribuição de "A".

- Administra o Centro de Distribuição de Peças de Reposição de uma montadora "B". Responde pelos serviços de pré-embalagem, recompra de peças de reposição e manuseio logístico de materiais importados. São 120 funcionários que movimentam 2,5 milhões de itens por mês. 
- Controla o armazém da maior fábrica de bebidas da América Latina "C". Recebe, armazena, localiza e controla os materiais para abastecimento da fábrica.

- Realiza a programação dos veículos que fazem o transporte das pessoas dentro do centro de produção de uma emissora de TV.

- Desenvolve a logística de produção e movimentação de materiais na gráfica e no armazém de produtos acabados da editora " $D$ ". A editora publica mais de 80 revistas/mês, o que resulta em um grande volume de material impresso e de movimentações diárias.

- Realiza a distribuição e coleta das correspondências e revistas dentro da editora "D", recebendo, separando e realizando a entrega do material, além de administrar os entregadores terceirizados, como Sedex, Speedpack, etc. "D” possui três mil empregados que movimentam cerca de 700 mil correspondências por dia.

- Recentemente foi contratada para realizar o transporte dos funcionários (jornalistas, fotógrafos, etc.) da editora "D" para eventos externos.

O trabalho de OL 5 começa realizando uma análise minuciosa do processo logístico, identificando suas deficiências para, finalmente, implantar a racionalização dos fluxos. Portanto, OL 5 atua como um fornecedor de soluções logísticas.

Na logística da gráfica e do armazém de "D”, por exemplo, OL 5 realizou várias visitas técnicas para conhecer de forma detalhada todos as etapas dos processos de produção e distribuição. Cumprida esta fase, realizou um diagnóstico dos fluxos, analisou os recursos disponíveis e indicou os investimentos necessários, sempre buscando a integração entre gráfica e o armazém.

O projeto proposto criou uma solução exclusiva e sob medida para as operações logísticas de " $\mathrm{D}$ ", racionalizando seus processos e, conseqüentemente, reduzindo custos e diferenciando suas operações.

\subsubsection{Fluxo de informação e TI no OL 5}

Quando OL 5 foi fundada, o grupo já possuía um ERP adquirido no mercado e que ainda continua em operação. O sistema ERP adotado é voltado para a administração de recursos humanos, fundamental para uma empresa prestadora de serviço. As outras soluções utilizadas pela empresa foram sendo desenvolvidas ao longo do tempo, conforme as necessidades dos seus clientes.

Para o gerenciamento dos armazéns, por exemplo, OL 5 dispõe de um WMS desenvolvido por uma Software House, sua parceira há cinco anos. OL 5 pode, também, 
administrar o armazém utilizando o WMS do próprio cliente. No caso da fábrica de bebidas "C" e da montadora "B", OL 5 utiliza o WMS das empresas para a administração dos armazéns. Já na distribuidora de gás "A" e na editora “D” utiliza o seu próprio WMS.

A licença para utilização do WMS não pertence a OL 5. O operador optou por alugar o software ao invés de comprá-lo porque os custos são semelhantes. A Software House é responsável pelas customizações necessárias para atender as particularidades de seus clientes.

Para o gerente de TI, o importante é o WMS estar aderente ao processo da empresa. Ser aderente significa ser capaz de controlar os estoques com relação ao vencimento dos produtos, permitir sua rápida localização nas prateleiras, apoiar a realização de transferências, etc. Deve, ainda, emitir relatórios e estatísticas que ajudem a operação a identificar problemas na armazenagem e melhorar o desempenho.

A figura abaixo representa o fluxo onde OL 5, a partir do seu WMS, envia as informações para seus clientes. 
Figura 31 - Fluxo de informação do OL 5

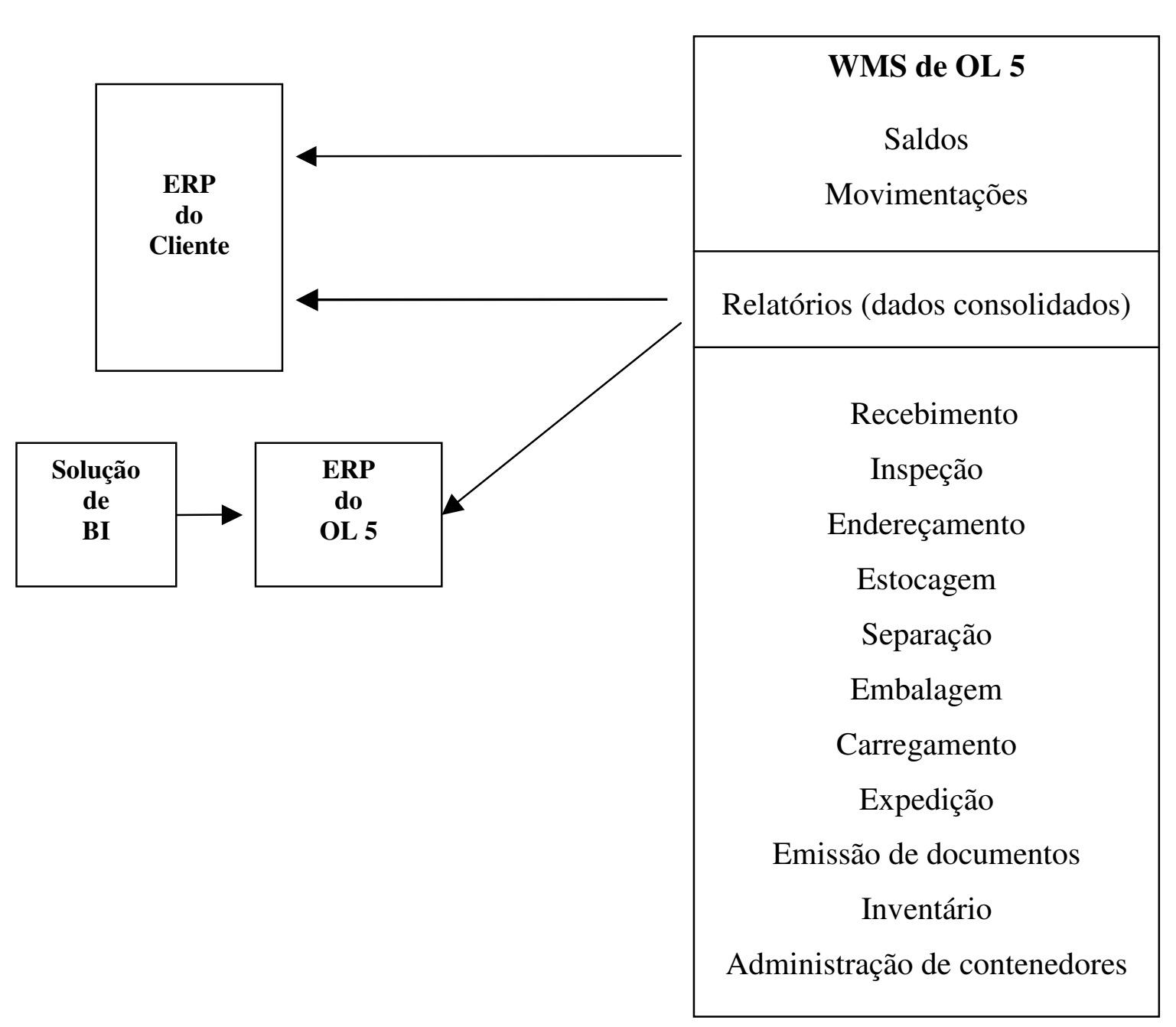

Fonte: elaborada pelo autor (2007).

OL 5 realiza o gerenciamento do armazém utilizando sua solução WMS. Os dados da operação como, por exemplo, localização, código de barras, transferência de endereço, etc. ficam armazenados no WMS. Para os clientes são disponibilizados somente os saldos, movimentações e os dados consolidados para análise. Estas informações podem ser gravadas diretamente no ERP do cliente ou ser enviadas por meio de arquivos em diversos formatos (txt, excel, etc.).

Os dados consolidados são, também, enviados para o ERP do OL 5 e são capturados pela solução de Business Intelligence (BI) mantida pelo operador. O BI organiza as informações, analisa e disponibiliza os resultados permitindo o seu gerenciamento. 
O foco de OL 5 está no desenvolvimento das operações. Portanto, quando precisa de uma ferramenta de TI para apoiar suas atividades, seu procedimento inicial é buscar as disponíveis no mercado e verificar sua aderência ao processo. Somente quando não encontra uma solução adequada às necessidades dos clientes, procura empresas capacitadas para desenvolver uma solução.

Segundo o gerente de TI, as soluções são desenvolvidas internamente somente quando demandam muita customização. O operador acredita que, neste caso, se buscar um desenvolvedor, pode estar colocando sua expertise em uma solução que, depois, poderá ser vendida no mercado. Nada impede que o cliente, ou mesmo um concorrente, compre a solução e, no futuro, preste o serviço.

OL 5 tem como objetivo atender plenamente aos seus clientes. A partir da definição dos serviços que serão executados, e das particularidades dos clientes, OL 5 elabora um projeto de prestação de serviço. O projeto procura racionalizar o processo logístico e apontar as ferramentas de TI que serão utilizadas.

$\mathrm{Na}$ distribuidora de gás “A”, por exemplo, OL 5 começou gerenciando o armazém e distribuindo os materiais para seus prestadores de serviço. Estes agentes executam as atividades externas para a distribuidora, como consertos e expansão da rede de gás. Retiram os materiais do armazém de "A" e levam para seus próprios armazéns onde ficarão disponíveis para serem utilizados.

Recentemente, "A" sentiu necessidade de manter um maior controle sobre os materiais estocados por estes prestadores. A empresa queria saber, com precisão, a quantidade de material em poder de cada prestador de serviço e, desta forma, evitar desperdícios. Solicitou à OL 5 o desenvolvimento de uma solução.

A solução que OL 5 utilizava no armazém operava com os coletores de código de barras tradicionais. Estes coletores têm preço elevado (em torno de US\$ 2.500) e não atendiam as necessidades de "A”. OL 5 buscou, então, uma solução que atendesse seu cliente. Por meio de uma parceria com uma empresa de telecomunicação foi desenvolvido um leitor de infravermelho que pode ser adaptado ao telefone celular e que permite, ao prestador de serviço, dar baixa nos materiais utilizados diretamente no WMS do armazém de "A". O custo desta solução é significativamente menor que o custo dos coletores convencionais, tornando viável sua implantação.

No recebimento e distribuição das correspondências e revistas de "D", o sistema foi desenvolvido internamente pelo OL 5. O sistema efetua o gerenciamento e controle das operações dos malotes, dando suporte a parte operacional e, também, ao gerenciamento do 
processo. $\mathrm{Na}$ parte operacional, entre outras funcionalidades, o sistema cadastra o quem recebe quais revistas e por quanto tempo. No gerenciamento, controla os fornecedores verificando se o número de correspondências e o valor cobrado estão corretos.

O operador é avaliado pelo seu desempenho e deve cumprir as metas estipuladas nos contratos. No caso do não cumprimento das metas, OL 5 é penalizado com a aplicação de multas. Para as entregas urgentes, por exemplo, o material deve chegar ao destinatário no prazo máximo de 10 minutos. Para ganhar agilidade e evitar as multas, OL 5 utiliza um Palmtop. Por meio do Palmtop o entregador pode dar baixa assim que a correspondência é entregue, economizando minutos preciosos.

No transporte externo dos funcionários da editora "D", OL 5 pretende utilizar um celular capaz de determinar a localização geográfica do aparelho por meio do Sistema de Posicionamento Global (Global Positioning System - GPS). O celular pode, ainda, estabelecer rotas entre dois pontos, receber e enviar informações, entre outras funcionalidades.

Finalmente, no caso da fábrica de bebidas "C", o cliente queria que OL 5 indicasse soluções de apoio à operação de seu armazém. OL 5 pesquisou no mercado e sugeriu o uso do RFID para monitoramento e rastreamento dos caminhões dentro do CD. A solução apresentada por OL 5 contribuiu de forma decisiva para a contratação do operador.

O RFID é um método de identificação automática onde um pequeno objeto, que responde aos sinais de rádio enviados por uma base transmissora, é colocado no produto para sua localização. Embora esta tecnologia seja ainda relativamente cara, foi possível implantá-la no controle do tráfego no armazém já que é utilizado apenas um dispositivo em cada caminhão.

O gerente de TI conclui afirmando que existe um grande número de tecnologias disponíveis no mercado. E, na logística, a inovação tecnológica está, sobretudo, nos periféricos que estão acoplados aos produtos que a empresa oferece. Mas, nem sempre o cliente está disposto a arcar com os elevados investimentos exigidos. A adoção das tecnologias depende da avaliação dos ganhos que irão trazer frente aos investimentos exigidos.

Atualmente, a área de TI está subordinada à diretoria administrativa e financeira e é composta por sete pessoas que servem às três empresas do grupo: um gerente, dois funcionários que cuidam da infra-estrutura da sede das empresas; dois funcionários para apoio aos sistemas corporativos, como o ERP; e dois funcionários que gerenciam os projetos e desenvolvem soluções. 


\subsubsection{Análise do papel da TI no apoio às atividades desenvolvidas}

As tecnologias utilizadas nas atividades logísticas serão analisadas a partir do posicionamento estratégico do operador, por meio da perspectiva interna e do mercado atendido (BERGLUND, 1997).

\section{Com relação à perspectiva interna:}

OL 5 é especializado no desenvolvimento da logística interna. A partir da identificação das necessidades de seus clientes, fornece as soluções logísticas mais adequadas. O operador é capaz de se adaptar à diferentes clientes, com objetivos estratégicos e estruturas organizacionais variadas, atuando em diferentes atividades de apoio à operação da empresa (flexibilidade)

OL 5 busca desenvolver a logística interna de modo a obter o menor custo possível para o nível de serviço oferecido (excelência logística). Portanto, além de uma gestão eficiente do processo logístico, buscando a racionalização dos fluxos e estoques; procura se diferenciar por meio do aporte de tecnologias que dêem suporte ao desenvolvimento do processo logístico, agregando maior valor à operação (BOWERSOX; CLOSS, 2001; BOWERSOX; CLOSS; STANK, 1999).

No gerenciamento dos armazéns, OL 5 dispõe de um WMS ou utiliza o WMS do cliente. Possui, ainda, um ERP e um sistema BI. Mas, seu grande diferencial está nas ferramentas que desenvolve para atender as necessidades específicas de seus clientes, como o leitor de infravermelho e o sistema de controle da correspondência.

O posicionamento estratégico de OL 5 visa, sobretudo, atender adequadamente seus clientes, adicionando o máximo de valor ao processo logístico, e atingir a flexibilidade sendo capaz de se adequar às mudanças nos mercados e aos diferentes clientes. A TI tem papel central (NOLAN; MCFARLAN, 2005; BOWERSOX; DAUGHERTY, 1995).

As tecnologias de informação vêm contribuindo para melhorar o processo de armazenagem, promovendo a racionalização das tarefas, maior controle das operações, sincronização das atividades; e, sobretudo, o desenvolvimento das operações dos clientes (GRAHAM; HARDAKER, 2000; BOWERSOX; CLOSS; STANK, 1999; STANK; KLEBER; CLOSS, 2001);

Mas, para que a TI contribua para a competitividade do processo logístico é necessário haver alinhamento entre a estratégia do negócio e da tecnologia (HENDERSON; 
VENKATRAMAN, 1993). No caso de OL 5, a estratégia do negócio determina a estratégia de TI adotada pela empresa e que, por sua vez, exige o estabelecimento de infra-estrutura de TI e processos adequados. A partir da definição dos serviços que serão executados, e das particularidades dos clientes, OL 5 elabora um projeto de prestação de serviço que indica as ferramentas de TI que serão utilizadas e a infra-estrutura necessária.

OL 5 enquadra-se, portanto, no alinhamento denominado por Henderson e Venkatraman (1993) de "Transformação Tecnológica". Neste alinhamento estratégico, a TI pode ser avaliada pelo que adicionou ao produto ou serviço final da empresa. Como nos casos já citados, notas-se a busca por tecnologias que viabilizem a estratégia do negócio.

Finalmente, analisando a importância das aplicações de TI presentes e futuras para o OL 5, pode-se concluir que seus sistemas de informação contribuem decisivamente para o seu sucesso na medida em que permitem que desenvolva o processo logístico de forma diferenciada. O operador apresenta, portanto, elevada "necessidade de TI confiável”.

O desenvolvimento do processo logístico interno está frequentemente colocando novos desafios para o OL 5. No momento, para apoiar sua primeira operação de logística externa, OL 5 está implantando um celular capaz de determinar a localização geográfica por meio do GPS. O operador tem elevada "necessidade de novas aplicações de TI". OL 5 pode ser enquadrado, portanto, no quadrante "Estratégico" (NOLAN; MCFARLAN, 2005).

\section{Com relação à perspectiva do mercado atendido:}

OL 5 atua no Brasil com empresas de vários setores; atuando exclusivamente nas atividades de logística interna; contribui para eficiência de seus clientes por possuir habilidade operacional; e por analisar o processo logístico e identificar suas necessidades para, a partir daí, propor uma reformulação.

Com relação às necessidades dos clientes, de acordo com OL 5:

- Não há diferença nas tecnologias utilizadas por OL 5 no desenvolvimento do trabalho logístico. Na gestão de armazéns, por exemplo, OL 5 utiliza a mesma solução WMS para clientes de qualquer setor. Mas, o WMS é uma solução genérica com diversas funcionalidades, e algumas delas podem não utilizadas no desenvolvimento das atividades de OL 5. As funcionalidades necessárias dependem do trabalho que será desenvolvido. A solução também deve atender as particularidades decorrentes das características do negócio. Por exemplo, forma de armazenagem, prazo de validade do produto, etc. Estas particularidades exigem a customização da ferramenta (BOWERSOX; CLOSS, 2001). 
- Com relação à política de produção, OL 5 utiliza a mesma tecnologia (WMS) em todos os clientes onde atua. Para o gerente de TI, a tecnologia é tão importante nas políticas de produção pull quanto na push.

\subsubsection{TI e a gestão integrada da logística}

Quanto a gestão integrada do processo logístico e ao estabelecimento das redes de valor, OL 5 não mantém integração entre o seus sistemas e os dos clientes, já que atua exclusivamente na logística interna. O WMS utilizado por OL 5 nas instalações dos clientes pode estar integrado ao ERP, mas as informações geradas não passam pelos sistemas de OL 5. OL 5 recebe apenas um relatório com os dados consolidados para análise de desempenho.

OL 5 não está integrada a seus fornecedores e ao seu único parceiro. Quanto aos fornecedores, utiliza eventualmente seus serviços e, portanto, não há integração. A relação que mantém com seu parceiro, o fornecedor do WMS, também não requer integração (BOWERSOX; CLOSS, 2001; BOWERSOX; DAUGHERTY, 1995; ASSUMPÇÃO, 2003; TURBAN; RAINER; POTTER, 2003). A parceria é motivada pela configuração complementar, onde as empresas buscam ampliar competências complementares (BRITTO, 2002).

Por atuar na logística interna, OL 5 não mantém nenhum nível de integração com seus clientes, fornecedores e parceiros e não pode ser enquadrado na classificação proposta por Venkatraman (1994).

Com relação à coordenação, OL 5 atua exclusivamente na logística interna e, portanto, não está envolvido na sincronização dos fluxos entre os agentes da cadeia. No desenvolvimento de suas atividades, o operador busca a racionalização do processo logístico, o que exige integração e sincronização dos fluxos de materiais e informação, mas restritas ao ambiente interno das empresas. O estabelecimento dos parâmetros e regulamentações que devem ser seguidos pelos agentes, tais como codificação de materiais e produtos, é determinado por seus clientes.

OL 5 é um operador logístico que atua exclusivamente na logística interna. Portanto, não podem ser identificados os fundamentos da logística integrada (BOWERSOX; CLOSS; STANK, 1999; BERGLUND, 1999, CHOPRA; MEINDL, 2001). Quando atua na gestão dos armazéns, os fluxos e estoques internos são administrados como um processo contínuo. Entretanto, não se estabelece uma rede de valor, já que não há o estabelecimento de parceria 
entre OL 5 e os clientes, e nem compartilhamento das informações (BOVET; MARTHA, 2001). 


\subsection{Comparação entre os operadores logísticos}

A pesquisa foi realizada com cinco operadores logísticos com atuação no mercado brasileiro:

- Operador logístico 1 (OL 1): presta serviço completo na terceirização logística dos processos de importação e exportação.

- Operador logístico 2 (OL 2): presta serviço em distribuição e operações logísticas exclusivamente para uma rede fast-food.

- Operador logístico 3 (OL 3): atua na armazenagem e na gestão do transporte e da cadeia de suprimentos especialmente nos setores automotivo, eletroeletrônico e de consumo.

- Operador logístico 4 (OL 4): atua na armazenagem e na gestão do transporte e da cadeia de suprimentos em empresas de todos os tamanhos e de setores variados.

- Operador logístico 5 (OL 5): atua na logística interna de empresas de vários setores.

OL 1 atua na logística internacional. OL 2, por atender a um único cliente, é bastante especializado. Os operadores logísticos 3 e 4 têm perfis semelhantes, mas enquanto OL 3 está focado em poucos setores, OL 4 é mais generalista. E, finalmente, OL 5 é especializado na logística interna.

Os cinco operadores estudados possibilitaram uma visão ampla do segmento já que atendem diferentes setores, apresentam diferentes características, desenvolvem diferentes atividades com diferentes posicionamentos estratégicos e, em conjunto, permitem analisar os três ciclos do processo logístico.

Os casos foram analisados individualmente, procurando consolidar as informações coletadas e ligá-las às proposições. A seguir, serão identificadas as semelhanças e diferenças verificadas entre eles. Este procedimento permite confirmar ou refutar as proposições iniciais e formular novas proposições.

Os quadros que virão a seguir destacam os principais elementos encontrados em cada estudo de caso. O quadro 7 apresenta uma caracterização dos operadores, o quadro 8 apresenta os elementos relativos às proposições 1, 2 e 3 e, finalmente, o quadro 9, os elementos relativos a proposição 4 . 


\subsubsection{Caracterização dos operadores logísticos}

O quadro 7 mostra a caracterização de cada uma das empresas analisadas, indicando os respondentes da pesquisa, suas estruturas de rede e seus principais fornecedores, clientes e parceiros.

\section{Quadro 7 - Caracterização dos operadores logísticos}

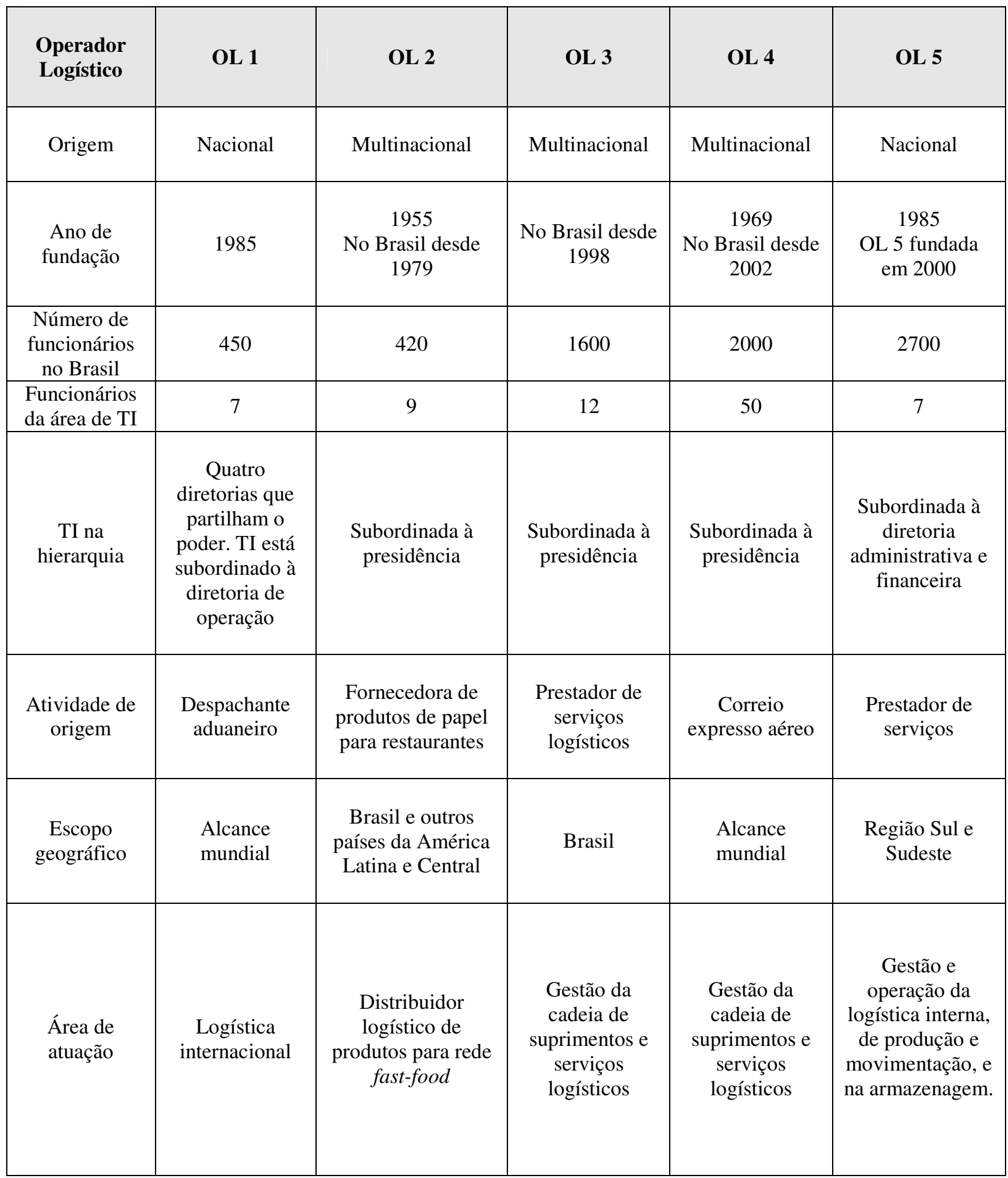




\begin{tabular}{|c|c|c|c|c|c|}
\hline Respondente & OL 1 & OL 2 & OL 3 & OL 4 & OL 5 \\
\hline Cargo & $\begin{array}{l}\text { Diretor de } \\
\text { operações }\end{array}$ & Diretor de TI & Diretor de TI & $\begin{array}{c}\text { Transportation } \\
\text { Operation } \\
\text { Leader (TI) } \\
\end{array}$ & Gerente de TI \\
\hline Formação & $\begin{array}{l}\text { Engenheiro } \\
\text { eletrônico }\end{array}$ & Analista de sistema & $\begin{array}{c}\text { Analista de } \\
\text { sistema }\end{array}$ & Administrador & $\begin{array}{l}\text { Engenheiro } \\
\text { Eletrônico }\end{array}$ \\
\hline Experiência & 20 anos & 27 anos & 29 anos & 22 anos & 20 anos \\
\hline $\begin{array}{l}\text { Tempo no } \\
\text { empresa }\end{array}$ & 9 anos & 13 anos & 7 anos & 3 anos & 7 anos \\
\hline \multicolumn{6}{|l|}{$\begin{array}{c}\text { Estrutura de } \\
\text { rede }\end{array}$} \\
\hline $\begin{array}{c}\text { Armazéns } \\
\text { ou CDs }\end{array}$ & $1 \mathrm{CD}$ de apoio & $\begin{array}{c}3 \text { CDs e } 2 \text { Centros } \\
\text { de Apoio }\end{array}$ & $11 \mathrm{CDs}$ & $25 \mathrm{CDs}$ & - \\
\hline Frota terrestre & 42 caminhões & 100 caminhões & Terceirizada & $\begin{array}{c}\text { Terceirizada } \\
100 \text { empresas } \\
\text { transportadoras }\end{array}$ & 120 automóveis \\
\hline Frota aérea & - & - & - & $\begin{array}{l}4 \text { Cia.Aéreas } \\
\text { No Brasil opera } \\
\text { com aviões } \\
\text { próprios e de } \\
\text { terceiros }\end{array}$ & - \\
\hline $\begin{array}{c}\text { Frota } \\
\text { marítima }\end{array}$ & - & - & - & Terceirizada & - \\
\hline \multicolumn{6}{|l|}{ Agentes } \\
\hline Clientes & $\begin{array}{l}\text { Supermercados, } \\
\text { indústria } \\
\text { farmacêutica, } \\
\text { cosméticos, } \\
\text { autopeças, } \\
\text { siderurgia, } \\
\text { eletro- } \\
\text { eletrônico e } \\
\text { informática. }\end{array}$ & Rede fast-food & $\begin{array}{l}\text { Automotivos, } \\
\text { eletro- } \\
\text { eletrônico e } \\
\text { varejo. }\end{array}$ & $\begin{array}{c}\text { Empresas de } \\
\text { todos os } \\
\text { tamanhos e com } \\
\text { necessidades } \\
\text { variadas. No } \\
\text { Brasil atende } \\
\text { empresas do } \\
\text { setor } \\
\text { automotivo, } \\
\text { químico e } \\
\text { industrial, } \\
\text { consumo e } \\
\text { varejo, saúde e } \\
\text { tecnologia. }\end{array}$ & $\begin{array}{c}\text { Alimentos e } \\
\text { bebidas; higiene } \\
\text { e cosméticos; } \\
\text { automotivo; } \\
\text { informática e } \\
\text { telecomunicação; } \\
\text { alimentos, } \\
\text { material } \\
\text { mecânico; } \\
\text { química e } \\
\text { petroquímica; } \\
\text { papel e celulose; } \\
\text { jornais e revistas. }\end{array}$ \\
\hline Fornecedores & $\begin{array}{c}\text { Outros } \\
\text { operadores } \\
\text { logísticos, } \\
\text { armadores, cia. } \\
\text { aéreas, agentes } \\
\text { de carga, } \\
\text { despachantes } \\
\text { aduaneiros, } \\
\text { transportadoras, } \\
\text { armazéns, } \\
\text { Receita Federal } \\
\text { e Banco } \\
\text { Central. } \\
\end{array}$ & $\begin{array}{c}\text { Fabricantes de } \\
\text { produtos a base de } \\
\text { carne, pães, } \\
\text { hortifrutigranjeiros, } \\
\text { batatas fritas, leite } \\
\text { e derivados, } \\
\text { refrigerantes, e } \\
\text { outros. }\end{array}$ & Transportadoras & Transportadoras & $\begin{array}{c}\text { Fornecedor e } \\
\text { desenvolvedor } \\
\text { de TI, } \\
\text { consultoria de } \\
\text { projetos e outros } \\
\text { operadores } \\
\text { logísticos. }\end{array}$ \\
\hline Parceiros & $\begin{array}{l}\text { Operador } \\
\text { logístico "A" }\end{array}$ & Rede fast-food & Transportadoras & - & $\begin{array}{c}\text { Courier e } \\
\text { fornecedor e } \\
\text { desenvolvedor } \\
\text { de TI }\end{array}$ \\
\hline
\end{tabular}

Fonte: elaborado pelo autor (2008). 
Todas as entrevistas foram realizadas com profissionais especializados da área de TI, com longo tempo no mercado e com profundo conhecimento de suas áreas. Três deles atuam em cargos de direção (OL1, OL 2 e OL 3). Com exceção do OL 4, todos os demais entrevistados já trabalham há um tempo significativo nas empresas e, portanto, foram capazes de recontar suas historias e o desenvolvimento da TI.

Com relação aos operadores que participaram da pesquisa:

- Quanto a origem, dois operadores são empresas nacionais (OL 1 e OL 5) e, os outros três, são multinacionais americanas (OL 2, OL 3 e OL 4). No caso de OL 4, foi adquirida posteriormente por um importante operador logístico alemão que manteve a marca para os serviços logísticos.

- Quanto ao escopo geográfico e o tempo de atuação, todos atuam no mercado brasileiro e dois deles (OL 1 e OL 4) tem atuação global. OL 2 é o operador que atua há mais tempo no Brasil (cerca de 30 anos), seguido de OL 1 (23 anos). Os demais operam há cerca de dez anos.

- Quanto ao número de funcionários, OL 1 e OL 2 mantêm cerca de 450 empregados. Os outros três operadores apresentam um número significativamente superior: respectivamente, 1600,2000 e 2700.

- OL 4 é o que apresenta o maior número de funcionários atuando na área de tecnologia de informação (50 pessoas). Este número é significativamente maior que dos outros operadores, mesmo comparando ao total de empregados.

- A TI ocupa uma posição de destaque na hierarquia de todas as empresas. Em três delas (OL2, OL 3 e OL 4) está subordinada diretamente à presidência e, nas outras duas (OL $1 \mathrm{e}$ OL 5), à diretoria.

- Quanto às atividades de origem, os operadores pesquisados são bastante diversificados. OL 1 iniciou sua atividades como despachante aduaneiro, OL 2 como atacadista no setor de papel para restaurantes, OL 3 como prestador de serviços logísticos, OL 4 como correio expresso aéreo e, finalmente, OL 5, com prestador de serviços gerais.

É interessante observar que as atividades de origem influenciaram, nestes casos, a especialização que o operador buscou ao longo dos anos: parece um caminho natural, por exemplo, que um operador que no inicio atuava como despachante aduaneiro (OL 1) venha se tornar um operador logístico internacional. Ou que um prestador de serviços gerais, como OL 5, especialize-se na logística interna.

A infra-estrutura disponibilizada pelos operadores também parece estar relacionada às atividades desenvolvidas: 
- OL 1 e OL 5, por exemplo, não precisam dispor de armazéns para o desenvolvimento de suas atividades. Já os armazéns e centros de apoio de OL 2 foram planejados para atender seu único cliente, a RFF. Os demais operadores possuem diversos CDs localizados de forma a atender ás necessidades de seus negócios.

- Com relação à frota terrestre, somente OL 1 e OL 2 possuem caminhões próprios, sendo que, no caso de OL 2, foram especialmente fabricados para atender seu cliente. Os outros dois operadores (OL 3 e OL 4) utilizam frota de terceiros. OL 3 mantém uma relação bastante próxima com estes prestadores de serviço, inclusive disponibilizando as tecnologias embarcadas nos caminhões. E OL 5 adquiriu, recentemente, 120 automóveis para realizar o transporte dos funcionários de uma editora.

Os operadores estabelecem a ligação entre os agentes da rede: clientes, fornecedores e parceiros.

- Quanto as indústrias atendidas (clientes), OL 2 possui um único cliente sendo, portanto, bastante especializada. OL 3 opera em poucos setores. Os outros operadores são mais diversificados atendendo clientes de vários segmentos.

- Quanto aos fornecedores, OL 1 utiliza os serviços dos armadores, cia. aéreas, transportadoras, armazéns e, eventualmente, outros operadores logísticos. OL 2 não tem fornecedores próprios. Seu trabalho é estabelecer a ligação entre os fornecedores de seu cliente e os pontos de venda. Os fornecedores de OL 3 e OL 4 são as empresas transportadoras. E, finalmente, OL 5 utiliza os serviços dos desenvolvedores de TI, empresas de consultoria e outros operadores logísticos.

- Finalmente, quanto aos parceiros, OL 1 mantém forte vínculo com o operador logístico "A", OL 2 com seu cliente, a rede fast-food, OL 3 com as empresas de transporte e OL 5 com o fornecedor de TI e com uma empresa de courier. OL 4 não mantém parcerias.

\subsubsection{Premissas e proposições}

A seguir serão apresentados os resultados levantados na pesquisa de campo para as premissas e proposições listadas no capítulo 6. São elas:

Premissa 1 - Para compreender como a TI é utilizada pelos operadores no processo logístico é preciso: 
Premissa 1.1 - Identificar o uso da TI em cada uma das cinco áreas do trabalho logístico e, dentro de cada área, nas diversas atividades (BOWERSOX; CLOSS, 2001; LAUDON; LAUDON, 2004).

Premissa 1.2 - Analisar o papel da TI no apoio às atividades desenvolvidas.

Proposição 1 - Para que o operador logístico torne-se flexível e atinja a eficácia é necessário o desenvolvimento de aplicativos customizados que atendam suas particularidades e garantam alinhamento entre os fatores externos e internos (BOWERSOX; DAUGHERTY, 1995; HENDERSON; VENKATRAMAN, 1993).

Proposição 2 - A complexidade logística e, portanto, a necessidade de aplicações de TI, são determinadas pelas características do setor.

Proposição 3 - Se a produção está baseada nas vendas efetivamente realizadas (pull) o papel desempenhado pela TI é mais importante do que quando está baseada na expectativa de vendas (push).

Proposição 4 - A TI está na base da gestão integrada da logística. E a gestão integrada da logística está na base do estabelecimento das redes de valor.

O quadro 8 apresenta os elementos relativos às premissas e as proposições 1,2 e 3 para os cinco casos analisados. 


\section{Quadro 8 - TI no processo logístico}

Premissas e proposições 1, 2 e 3

\begin{tabular}{|c|c|c|c|c|c|}
\hline \multicolumn{6}{|c|}{ Premissa 1} \\
\hline \multicolumn{6}{|c|}{ Premissa 1.1 } \\
\hline $\begin{array}{l}\text { Processo } \\
\text { logístico }\end{array}$ & OL 1 & OL 2 & OL 3 & OL 4 & OL 5 \\
\hline $\begin{array}{c}\text { Ciclos de } \\
\text { distribuição, } \\
\text { de apoio à } \\
\text { manufatura e } \\
\text { de } \\
\text { suprimentos. }\end{array}$ & $\begin{array}{l}\text { Opera nos três } \\
\text { ciclos }\end{array}$ & $\begin{array}{c}\text { Ciclo de } \\
\text { distribuição e } \\
\text { suprimentos }\end{array}$ & $\begin{array}{l}\text { Opera nos três } \\
\text { ciclos }\end{array}$ & $\begin{array}{l}\text { Opera nos três } \\
\text { ciclos }\end{array}$ & $\begin{array}{l}\text { Opera no ciclo } \\
\text { de apoio à } \\
\text { manufatura }\end{array}$ \\
\hline Atividades & $\begin{array}{l}\text { Serviço } \\
\text { completo de } \\
\text { terceirização } \\
\text { logística na } \\
\text { exportação e } \\
\text { importação }\end{array}$ & $\begin{array}{l}\text { Aquisição, } \\
\text { armazenagem e } \\
\text { distribuição dos } \\
\text { produtos para } \\
\text { rede fast-food }\end{array}$ & $\begin{array}{l}\text { Armazenagem, } \\
\text { gestão do } \\
\text { transporte e da } \\
\text { cadeia de } \\
\text { suprimentos, e } \\
\text { logística interna. }\end{array}$ & $\begin{array}{l}\text { Armazenagem, } \\
\text { gestão do } \\
\text { transporte e da } \\
\text { cadeia de } \\
\text { suprimentos, e } \\
\text { logística } \\
\text { interna. } \\
\end{array}$ & $\begin{array}{c}\text { Movimentação } \\
\text { e armazenagem } \\
\text { de produtos, } \\
\text { materiais, } \\
\text { componentes e } \\
\text { peças semi- } \\
\text { acabadas. } \\
\end{array}$ \\
\hline \multicolumn{6}{|l|}{$\begin{array}{c}\text { Tecnologias } \\
\text { de } \\
\text { informação }\end{array}$} \\
\hline ERP & - & $\begin{array}{l}\text { Atende as tarefas } \\
\text { básicas. } \\
\text { Adquirido no } \\
\text { mercado, foi } \\
\text { sendo } \\
\text { complementado } \\
\text { pelos módulos do } \\
\text { "Sistema Órbita" }\end{array}$ & $\begin{array}{c}\text { Focado no } \\
\text { gerenciamento } \\
\text { da parte } \\
\text { documental } \\
\text { Adquirido no } \\
\text { mercado, foi } \\
\text { sendo } \\
\text { customizado ao } \\
\text { longo do tempo. }\end{array}$ & - & $\begin{array}{l}\text { Focado na } \\
\text { administração } \\
\text { de recursos } \\
\text { humanos. } \\
\text { Adquirido no } \\
\text { mercado. }\end{array}$ \\
\hline WMS & - & $\begin{array}{l}\text { Utiliza partes do } \\
\text { WMS. } \\
\text { Adquirido no } \\
\text { mercado }\end{array}$ & $\begin{array}{l}\text { Desenvolvido } \\
\text { por uma } \\
\text { Software House } \\
\text { para atender suas } \\
\text { necessidades }\end{array}$ & $\begin{array}{l}\text { - WMS } \\
\text { herdado de } \\
\text { uma das } \\
\text { empresas } \\
\text { que foi } \\
\text { adquirida } \\
\text { pelo grupo. } \\
\text { É ainda } \\
\text { utilizado por } \\
\text { cerca de 30\% } \\
\text { dos clientes. } \\
\text { - WMS } \\
\text { desenvolvido } \\
\text { por uma } \\
\text { Software } \\
\text { House } \\
\text { italiana. } \\
\text { Adotado em } \\
\text { todo o } \\
\text { mundo }\end{array}$ & $\begin{array}{c}\text { - WMS } \\
\text { desenvolvido } \\
\text { por uma } \\
\text { Software } \\
\text { House e } \\
\text { alugado por } \\
\text { OL 5. } \\
\\
\text { - WMS do } \\
\text { cliente }\end{array}$ \\
\hline
\end{tabular}




\begin{tabular}{|c|c|c|c|c|c|}
\hline $\begin{array}{c}\text { Tecnologias } \\
\text { de } \\
\text { informação }\end{array}$ & OL 1 & OL 2 & OL 3 & OL 4 & OL 5 \\
\hline TMS & - & - & $\begin{array}{l}\text { Adquirido no } \\
\text { mercado }\end{array}$ & $\begin{array}{l}\text { Desenvolvido } \\
\text { internamente }\end{array}$ & - \\
\hline $\begin{array}{c}\text { Tecnologia } \\
\text { embarcada nos } \\
\text { caminhões ou, } \\
\text { no caso } \\
\text { particular de } \\
\text { OL 5, nos } \\
\text { veículos }\end{array}$ & $\begin{array}{c}\text { Sistema de } \\
\text { Posicionamento } \\
\text { Global (GPS) } \\
\text { para } \\
\text { rastreamento e } \\
\text { roteirização }\end{array}$ & $\begin{array}{l}\text { - Computador de } \\
\text { bordo que } \\
\text { registra os } \\
\text { movimentos } \\
\text { físicos do } \\
\text { caminhão } \\
\text { - Palm-top } \\
\text { equipado com } \\
\text { software de } \\
\text { gestão de rota } \\
\text { (GPS) }\end{array}$ & $\begin{array}{c}\text { - Computador } \\
\text { de bordo que } \\
\text { controla a } \\
\text { localização do } \\
\text { caminhão } \\
\text { (GPS) } \\
\text { - Computador } \\
\text { que protege a } \\
\text { carga, } \\
\text { equipado com } \\
\text { o software e- } \\
\text { cargo de } \\
\text { controle e } \\
\text { rastreamento } \\
\text { de cargas e } \\
\text { entregas. }\end{array}$ & $\begin{array}{c}\text { A cargo das } \\
\text { transportadoras }\end{array}$ & $\begin{array}{l}\text { - Celular } \\
\text { equipado com } \\
\text { GPS. Capaz } \\
\text { de estabelecer } \\
\text { rotas entre } \\
\text { dois pontos, } \\
\text { receber e } \\
\text { enviar } \\
\text { informações, } \\
\text { etc. } \\
\text { RFID para } \\
\text { monitoramento } \\
\text { e rastreamento } \\
\text { dos caminhões } \\
\text { dentro do CD } \\
\text { do cliente. }\end{array}$ \\
\hline $\begin{array}{l}\text { Sistemas de } \\
\text { informação }\end{array}$ & $\begin{array}{c}\text { Composto de } \\
\text { duas partes: } \\
\text { exportação e } \\
\text { importação. } \\
\text { Cada parte tem } \\
\text { vários módulos } \\
\text { que apóiam o } \\
\text { desenvolvimento } \\
\text { das atividades. } \\
\text { Desenvolvido } \\
\text { internamente }\end{array}$ & $\begin{array}{c}\text { Sistema Órbita: } \\
\text { possui vários } \\
\text { módulos, entre } \\
\text { eles: “pedido via } \\
\text { web" e } \\
\text { “gerenciador de } \\
\text { campanha”, DPR } \\
\text { que controla o } \\
\text { fornecimento dos } \\
\text { produtos. } \\
\text { Desenvolvido } \\
\text { internamente }\end{array}$ & - & $\begin{array}{c}\text { Sistema Fiscal } \\
\text { Logístico } \\
\text { (SFL) que } \\
\text { executa a parte } \\
\text { fiscal. } \\
\text { Desenvolvido } \\
\text { internamente }\end{array}$ & $\begin{array}{l}\text { - Leitor de } \\
\text { infravermelho } \\
\text { adaptado ao } \\
\text { telefone } \\
\text { celular. } \\
\text { - Sistema de } \\
\text { controle e } \\
\text { gestão das } \\
\text { operações de } \\
\text { malotes. } \\
\text { - Palmtop para } \\
\text { o entregador } \\
\text { dar baixa na } \\
\text { correspondên } \\
\text { cia quando } \\
\text { entregue }\end{array}$ \\
\hline $\begin{array}{c}\text { Business } \\
\text { Intelligence } \\
\text { (BI) }\end{array}$ & $\begin{array}{c}\text { Desenvolveu } \\
\text { internamente } \\
\text { algumas } \\
\text { funcionalidades } \\
\text { do sistema que } \\
\text { permitem } \\
\text { analisar e } \\
\text { disponibilizar os } \\
\text { resultados para o } \\
\text { gerenciamento. }\end{array}$ & $\begin{array}{c}\text { Trata as } \\
\text { informações } \\
\text { coletadas na } \\
\text { entrega e produz } \\
\text { relatórios } \\
\text { estatísticos. } \\
\text { Desenvolvido } \\
\text { internamente. }\end{array}$ & - & - & $\begin{array}{c}\text { Organiza as } \\
\text { informações, } \\
\text { analisa e } \\
\text { disponibiliza os } \\
\text { resultados } \\
\text { permitindo o } \\
\text { gerenciamento. } \\
\text { Adquirido no } \\
\text { mercado. }\end{array}$ \\
\hline $\begin{array}{c}\text { Em } \\
\text { implantação }\end{array}$ & & $\begin{array}{l}\text { Módulo VMI do } \\
\text { Sistema Órbita } \\
\text { com informação } \\
\text { sobre os } \\
\text { estoques, a } \\
\text { demanda e o } \\
\text { consumo efetivo } \\
\text { nas lojas para } \\
\text { fornecedores. }\end{array}$ & $\begin{array}{c}\text { Software para } \\
\text { consolidação das } \\
\text { cargas } \\
\text { Adquirido no } \\
\text { mercado }\end{array}$ & $\begin{array}{c}\text { Pesquisando no } \\
\text { mercado para } \\
\text { adquirir um } \\
\text { novo TMS. }\end{array}$ & - \\
\hline
\end{tabular}




\begin{tabular}{|c|c|c|c|c|c|}
\hline \multicolumn{6}{|c|}{ Premissa 1.2} \\
\hline Interna & OL 1 & OL 2 & OL 3 & OL 4 & OL 5 \\
\hline Metas & $\begin{array}{l}\text { Flexibilidade e } \\
\text { Eficácia }\end{array}$ & $\begin{array}{l}\text { Flexibilidade e } \\
\text { Eficácia }\end{array}$ & $\begin{array}{l}\text { Flexibilidade e } \\
\text { Eficácia }\end{array}$ & $\begin{array}{c}\text { Flexibilidade e } \\
\text { Eficácia }\end{array}$ & $\begin{array}{c}\text { Flexibilidade e } \\
\text { Eficácia }\end{array}$ \\
\hline Alinhamento & $\begin{array}{c}\text { Transformação } \\
\text { Tecnológica }\end{array}$ & $\begin{array}{l}\text { Transformação } \\
\text { Tecnológica }\end{array}$ & $\begin{array}{c}\text { Transformação } \\
\text { Tecnológica }\end{array}$ & $\begin{array}{l}\text { Nível de } \\
\text { Serviço }\end{array}$ & $\begin{array}{c}\text { Transformação } \\
\text { Tecnológica }\end{array}$ \\
\hline $\begin{array}{c}\text { Grid } \\
\text { Estratégico }\end{array}$ & Fábrica & Estratégico & Estratégico & Fábrica & Estratégico \\
\hline $\begin{array}{l}\text { Mercado } \\
\text { Atendido }\end{array}$ & & & & & \\
\hline $\begin{array}{l}\text { Complexidade } \\
\text { Logística }\end{array}$ & $\begin{array}{c}\text { Clientes com } \\
\text { diferentes níveis } \\
\text { de complexidade }\end{array}$ & $\begin{array}{l}\text { Um único cliente } \\
\text { com elevada } \\
\text { complexidade }\end{array}$ & $\begin{array}{c}\text { Clientes com } \\
\text { diferentes níveis } \\
\text { de complexidade }\end{array}$ & $\begin{array}{c}\text { Clientes com } \\
\text { diferentes } \\
\text { níveis de } \\
\text { complexidade }\end{array}$ & $\begin{array}{l}\text { Clientes com } \\
\text { diferentes } \\
\text { níveis de } \\
\text { complexidade }\end{array}$ \\
\hline $\begin{array}{l}\text { Políticas de } \\
\text { produção }\end{array}$ & $\begin{array}{l}\text { Atua no ciclo de } \\
\text { manufatura de } \\
\text { um único cliente }\end{array}$ & $\begin{array}{c}\text { Não atua no ciclo } \\
\text { de apoio à } \\
\text { manufatura }\end{array}$ & $\begin{array}{l}\text { Atua no ciclo de } \\
\text { apoio à } \\
\text { manufatura de } \\
\text { três clientes }\end{array}$ & $\begin{array}{c}\text { Atua no ciclo } \\
\text { de apoio à } \\
\text { manufatura de } \\
\text { diversos } \\
\text { clientes } \\
\end{array}$ & $\begin{array}{l}\text { Atua no ciclo } \\
\text { de apoio à } \\
\text { manufatura de } \\
\text { diversos } \\
\text { clientes } \\
\end{array}$ \\
\hline \multicolumn{6}{|c|}{ Proposição 1} \\
\hline $\begin{array}{l}\text { Customização } \\
\text { dos aplicativos }\end{array}$ & Sim & Sim & Sim & $\begin{array}{l}\text { Sim, mas para } \\
\text { adequação ao } \\
\text { WMS mundial }\end{array}$ & Sim \\
\hline \multicolumn{6}{|c|}{ Proposição 2} \\
\hline $\begin{array}{l}\text { Complexidade } \\
\text { logística } \\
\text { versus setor de } \\
\text { atuação } \\
\end{array}$ & $\begin{array}{l}\text { Não existem } \\
\text { diferenças entre } \\
\text { os setores }\end{array}$ & $\begin{array}{l}\text { Não existem } \\
\text { elementos para } \\
\text { análise }\end{array}$ & $\begin{array}{l}\text { Não existem } \\
\text { diferenças entre } \\
\text { os setores }\end{array}$ & $\begin{array}{c}\text { Não existem } \\
\text { diferenças } \\
\text { entre os setores }\end{array}$ & $\begin{array}{c}\text { Não existem } \\
\text { diferenças entre } \\
\text { os setores }\end{array}$ \\
\hline \multicolumn{6}{|c|}{ Proposição 3} \\
\hline $\begin{array}{l}\text { Políticas de } \\
\text { produção } \\
\text { versus papel } \\
\text { da TI } \\
\end{array}$ & $\begin{array}{l}\text { Não existem } \\
\text { elementos para } \\
\text { análise }\end{array}$ & $\begin{array}{l}\text { Não existem } \\
\text { elementos para } \\
\text { análise }\end{array}$ & $\begin{array}{l}\text { Importância da } \\
\text { TI é a mesma }\end{array}$ & $\begin{array}{l}\text { Importância da } \\
\text { TI é a mesma }\end{array}$ & $\begin{array}{l}\text { Importância da } \\
\text { TI é a mesma }\end{array}$ \\
\hline
\end{tabular}

Fonte: elaborado pelo autor (2008).

O quadro 9 abaixo analisa a proposição 4 , relativa ao estabelecimento das redes de valor, para os operadores logísticos pesquisados. 
Quadro 9 - TI no estabelecimento das redes de valor

\begin{tabular}{|c|c|c|c|c|c|}
\hline \multicolumn{6}{|c|}{ Proposição 4} \\
\hline Redes de Valor & OL 1 & OL 2 & OL 3 & OL 4 & OL 5 \\
\hline Integração & $\begin{array}{l}\text { - “A” plena } \\
\text { - Clientes: } \\
\text { pode ser } \\
\text { plena. } \\
\text { - Armadores: } \\
\text { OL 1 } \\
\text { atualiza e } \\
\text { capta } \\
\text { informação } \\
\text { - Receita } \\
\text { Federal: OL } \\
1 \text { atualiza e } \\
\text { capta } \\
\text { informação }\end{array}$ & $\begin{array}{l}\text { - Cliente: plena } \\
\text { - Fornecedores: } \\
\text { parcial, mas } \\
\text { evoluindo para } \\
\text { plena. }\end{array}$ & $\begin{array}{l}\text { - Clientes: plena } \\
\text { (EDI sobre redes } \\
\text { privadas) } \\
\text { - Transportadoras: } \\
\text { plena }\end{array}$ & $\begin{array}{c}\text { Níveis variados. } \\
\text { Capaz de } \\
\text { estabelecer } \\
\text { integração plena, } \\
\text { mas depende do } \\
\text { desenvolvimento } \\
\text { tecnológico dos } \\
\text { agentes (clientes } \\
\text { e } \\
\text { transportadoras) }\end{array}$ & $\begin{array}{c}\text { Não há } \\
\text { integração }\end{array}$ \\
\hline Coordenação & Operador "A" & OL 2 & Clientes & Clientes & $\begin{array}{l}\text { Não se aplica. } \\
\text { Sincronização } \\
\text { dos fluxos no } \\
\text { ambiente } \\
\text { interno. } \\
\end{array}$ \\
\hline $\begin{array}{c}\text { Estabelecimento } \\
\text { de parâmetro e } \\
\text { regulamentações }\end{array}$ & $\begin{array}{l}\text { Determinado } \\
\text { pelos clientes }\end{array}$ & OL 2 & $\begin{array}{l}\text { Determinado } \\
\text { pelos clientes }\end{array}$ & $\begin{array}{l}\text { Determinado } \\
\text { pelos clientes }\end{array}$ & $\begin{array}{l}\text { Determinado } \\
\text { pelos clientes }\end{array}$ \\
\hline $\begin{array}{l}\text { Parcerias de } \\
\text { longo prazo }\end{array}$ & $\begin{array}{c}\text { Operador } \\
\text { logístico "A" }\end{array}$ & Rede fast-food & Transportadoras & - & $\begin{array}{l}\text { Desenvolvedor } \\
\text { de software }\end{array}$ \\
\hline
\end{tabular}

Fonte: elaborado pelo autor (2008).

A seguir, serão detalhados os principais pontos apresentados nos quadros 8 e 9 para os casos analisados.

\subsubsection{Processo logístico e atividades dos operadores}

Quanto ao processo logístico, OL 1 atua nos três ciclos executando um serviço completo de terceirização logística na exportação e importação. OL 3 e OL 4 também atuam nos três ciclos realizando as atividades de armazenagem, gestão do transporte e da cadeia de suprimentos, e na logística interna. OL 2 atua nos ciclos de distribuição e suprimentos realizando a compra, armazenagem e distribuição de todos os produtos secos, resfriados e congelados utilizados pelo seu cliente. E, finalmente, OL 5 opera no ciclo de apoio à 
manufatura executando as atividades de movimentação e armazenagem de produtos, materiais, componentes e peças semi-acabadas.

\subsubsection{Fluxo de informação e TI nos operadores}

No que se refere às tecnologias de informação adotadas pelos operadores:

- OL 2, OL 3 e OL 5 possuem sistemas ERP adquiridos no mercado. No caso de OL 2 e OL 3, os sistemas foram, ao longo do tempo, customizados para atender as necessidades das empresas.

- Com exceção de OL 1, todos os operadores possuem WMS. No caso de OL 2, o operador utiliza somente parte de um WMS adquirido no mercado. Nos demais operadores, o WMS foi especialmente desenvolvido por empresas de software para atender suas necessidades. OL 4 utiliza dois WMS: o adotado pela empresa em todo o mundo e o herdado de uma das empresas adquirida pelo grupo. Finalmente, OL 5, que em alguns casos, opera utilizando o WMS do cliente.

- Somente OL 3 e OL 4 utilizam TMS. No caso de OL 3, o sistema foi adquirido no mercado. Já o sistema de OL 4 foi desenvolvido internamente para que pudesse se adequar ao WMS mundial.

- Quanto a tecnologia embarcada nos caminhões, no caso de OL 4, como opera com transportadoras com níveis variados de desenvolvimento tecnológico, nem todas possuem este sistema. Mas, nas demais, todos os caminhões são equipados com GPS para rastreamento e roteirização. Cada operador adota um tipo de receptor: OL 2 utiliza, no momento, Palm-top, mas está mudando para tecnologia Bluetooth, OL 5 utiliza aparelho celular e, OL 3, o computador de bordo. No caso particular de OL 3, como tem grande preocupação com a segurança, todos os caminhões são equipados também com um software para controle e rastreamento de suas cargas. Finalmente, OL 5 vem utilizando RFID no armazém de um grande fabricante de bebidas.

- Quanto a outros sistemas de informação, todos foram desenvolvidos internamente e dão suporte às atividades de cada operador. OL 1 utiliza um sistema de apoio à exportação e importação; OL 2 o "Sistema Órbita", integrado ao seu ERP e que é o diferencial de seu negócio; OL 4 o "Sistema Fiscal Logístico" que executa a parte fiscal e de documentação substituindo o sistema ERP e, finalmente, OL 5, cujas atividades são mais diversificadas que a dos demais operadores, o sistema de controle de gestão da correspondência interna e leitor infravermelho que pode ser adaptado ao aparelho celular. 
- Quanto aos aplicativos de Business Intelligence, estes softwares permitem, a partir de um grande volume de dados, extrair informações e transformá-las em conhecimento. Entre as informações extraídas por OL 2, por exemplo, estão previsão de vendas, recebimento de pedidos, controle de estoques próprios e dos fornecedores, relatório de vendas por lojas, caixas entregues por rota, tempo de permanência do caminhão no restaurantes, etc. OL 5 analisa indicadores como metas em cada cliente, produtividade, etc.

- Quanto aos sistemas em implantação, OL 2 está desenvolvendo um módulo VMI com informações para seus fornecedores, OL 3 está implantando um software para consolidação de cargas adquirido no mercado, e OL 4 está buscando no mercado um novo TMS.

\subsubsection{Análise do papel da TI no apoio às atividades desenvolvidas}

O papel da TI no apoio as atividades desenvolvidas pode ser analisado por meio do posicionamento estratégico do operador. E o posicionamento estratégico pode ser compreendido por meio de duas perspectivas: interna e do mercado atendido (BERGLUND, 1997).

Com relação à perspectiva interna:

Todos os operadores têm com meta atingir a flexibilidade - capacidade para se adequar a diferentes situações e parceiros - e eficácia - adicionar o máximo de valor ao processo logístico por meio de qualidade e diferenciação. A TI tem, portanto, papel central (BOWERSOX; CLOSS; STANK, 1999).

- No OL 1, o sistema de informação utilizado vem possibilitando a disponibilização e troca das informações com seus clientes e parceiro "A", dando apoio a execução integral do processo de exportação e importação e a sua atuação mundial, contribuindo para a qualidade dos serviços e facilitando a customização e adaptação do operador aos diferentes clientes e oportunidades.

- No caso de OL 2, a flexibilidade diz respeito exclusivamente a adequação a novas situações, uma vez que opera com um único cliente obedecendo padrões rígidos. O "Sistema Órbita" vem dando suporte às atividades desenvolvidas pelo operador possibilitando um maior controle dos processos logísticos, e permitindo a inovação por meio dos módulos como "pedidos via web" e "gerenciador de campanhas". Além de 
melhorar o desempenho e o controle, e de reduzir custos, a TI vem contribuindo para o crescimento da empresa que vem ampliando seus mercados.

- O OL 3, além de uma gestão eficiente dos fluxos e estoques, procura se diferenciar por meio do desenvolvimento de processos e da disponibilização das informações para seus clientes. Os sistemas que utiliza - ERP, WMS, TMS - dão acesso às informações e suporte a qualquer processo desenvolvido pelo operador. Para garantir a segurança, aspecto crítico para este operador, utiliza um sistema de tracking. Quanto a flexibilidade, os sistemas foram construídos, ainda, para se adaptar a qualquer infraestrutura de rede e se integrar aos sistemas de seus clientes e fornecedores.

- No OL 4, as tecnologias de informação utilizadas pelo operador - TMS, SFL, e o WMS herdado - foram desenvolvidas para complementar as funcionalidades do sistema WMS PROLOGS, adotado pela empresa em todo o mundo. O PROLOGS é um sistema bastante flexível, com capacidade de se comunicar com diversos ERPs. A transferência eletrônica de informação pode ser realizada de diversas maneiras, garantindo o atendimento de qualquer cliente com qualquer nível tecnológico. Além da flexibilidade, as tecnologias de informação vêm contribuindo para a diferenciação do operador, apoiando o desenvolvimento de processos e permitindo a disponibilização das informações para seus clientes.

- O OL 5 utiliza, para desenvolver suas atividades básicas, um WMS. Mas, seu diferencial está no aporte das tecnologias que dão suporte ao desenvolvimento do processo logístico dos clientes, agregando maior valor à operação. Incluem-se nesta categoria o leitor de infravermelho que pode ser acoplado ao celular, o sistema de gestão da correspondência interna e o RFID para controle do tráfego dos caminhões dentro do armazém. Flexibilidade, para este operador, está relacionada a sua capacidade de, a partir da identificação das necessidades de seus clientes, fornecer as soluções logísticas adequadas e as ferramentas de TI apropriadas.

A contribuição da TI para a competitividade do processo logístico exige alinhamento entre a estratégia do negócio e da tecnologia (HENDERSON; VENKATRAMAN, 1993).

- Para OL 1, OL 2, OL 3 e OL 5 a estratégia do negócio determinou a estratégia de TI adotada pelos operadores que, por sua vez, exigiu o estabelecimento de infra-estrutura de TI e processos adequados. Desta forma, estes operadores enquadram-se no alinhamento denominado de "Transformação Tecnológica".

- No caso de OL 4, a estratégia de TI foi determinada pela matriz da empresa que adotou o mesmo software em todo o mundo, e obrigou o operador a desenvolver sistemas 
periféricos para cobrir suas deficiências. Assim, a estratégia de TI resultou em uma nova estrutura de TI, afetando a estrutura de negócios (Alinhamento Nível de Serviço). Pode-se constatar que a TI é eficaz, trazendo para o operador vantagens competitivas.

Finalmente, analisando a importância das aplicações de TI, presentes e futuras, para o operador logístico pode-se concluir que (MCFARLAN, 1984):

- As aplicações atuais de TI contribuem para o sucesso dos OL 1 e OL 4. Mas, no horizonte de planejamento considerado pelos entrevistados, não foram identificadas pressões por novas aplicações de TI. OL 1 prevê apenas atualizações de seu sistema e OL 4 a adoção de um novo TMS. Estes dois operadores podem ser enquadrados, portanto, no quadrante "Fábrica".

- As aplicações de TI, presentes e futuras, são fundamentais para a estratégia dos OL 2, OL 3 e OL 5. Os sistemas atualmente utilizados pelos três operadores são fundamentais para o desenvolvimento de seus processos logísticos e estão previstas a implantação de novos sistemas. Podem ser enquadrados, portanto, no quadrante "Estratégico".

\section{Com relação à perspectiva do mercado atendido}

- Todos os operadores, com exceção de OL 2, afirmaram empregar os mesmos sistemas para todos os clientes, qualquer que seja o setor de atuação. Qualquer que seja o setor do cliente, o processo logístico é igual e envolve as mesmas atividades. Portanto, são utilizadas as mesmas tecnologias. As particularidades do setor podem exigir diferentes formas de organização das informações. Nestes casos, os operadores customizam as interfaces, disponibilizando as informações no formato adequado. No caso de OL 2, como atende um único cliente do setor de alimentos, não há elementos para confirmar ou refutar a proposição.

- Com relação à política de produção, os três operadores que atuam no ciclo logístico de apoio à manufatura (OL 3, OL 4 e OL 5) afirmaram que a TI tem a mesma importância nas políticas de produção pull ou push. Para OL 3 "o que pode mudar é a freqüência na entrega de material que deve ser maior nas políticas pull”. No caso de OL 1 e OL 2, por não atuarem no abastecimento de linhas de produção, não foi possível extrair elementos para a análise da proposição. 


\subsubsection{A TI como base da gestão integrada da logística e do estabelecimento das redes} de valor.

No que se refere à integração entre os agentes, com exceção de OL 5 por suas particularidades, todos os operadores têm capacidade de manter integração plena com seus clientes. Já quanto aos fornecedores, somente OL 2 vem buscando uma maior integração. OL 1 também está plenamente integrado ao seu parceiro, operador logístico "A", OL 3 às, também suas parceiras, empresas de transporte e OL 4, quando possível, também integra-se às transportadoras.

Finalmente, o único operador que coordena o processo logístico e estabelece os parâmetros e regulamentações é OL 2. Nos demais, estas atribuições estão a cargo dos clientes.

\section{XXX}

A primeira parte deste capítulo 7 descreveu, brevemente, a indústria logística. $\mathrm{Na}$ segunda parte foi feita a análise individual de cada um dos cinco casos estudados e, em seguida, a análise cruzada, identificando as semelhanças e diferenças existentes entre eles. Foi possível assim analisar cada caso de acordo com as premissas e verificar cada uma das proposições, quando sua aceitação ou não.

A seguir serão apresentadas as conclusões finais, buscando responder as questões propostas, confirmar ou refutar as proposições iniciais, formular novas proposições e apontar possibilidades para o desenvolvimento de novos estudos. 


\section{CONCLUSÃO}

A pesquisa tinha como objetivos compreender como a TI vem sendo utilizada nos processos logísticos e como contribui para o estabelecimento das redes de valor. Duas questões fundamentaram o desenvolvimento do estudo.

1. Como a TI é utilizada pelos operadores no processo logístico?

2. Como a TI contribui para o estabelecimento das redes de valor?

Para atingir os objetivos foi realizado estudo com cinco operadores logísticos que atuavam em diferentes setores, com diferentes características, posicionamentos estratégicos e que, em conjunto, cobrissem os três ciclos do processo logístico.

- OL 1 presta serviço completo na terceirização logística dos processos de importação e exportação.

- OL 2 presta serviço em distribuição e operações logísticas exclusivamente para uma rede fast-food.

- OL 3 atua na armazenagem e na gestão do transporte e da cadeia de suprimentos especialmente nos setores automotivo, eletroeletrônico e de consumo.

- OL 4 atua na armazenagem e na gestão do transporte e da cadeia de suprimentos em empresas de todos os tamanhos e de setores variados.

- OL 5 atua na logística interna de empresas de vários setores.

OL 1 atua na logística internacional. OL 2, por atender a um único cliente, é bastante especializado. Os operadores logísticos 3 e 4 tem perfis semelhantes, mas enquanto OL 3 está focado em poucos setores, OL 4 é mais generalista. E, finalmente, OL 5 é especializado na logística interna.

Dois dos operadores têm alcance mundial e os demais atuam exclusivamente no Brasil, operam em diversos setores podendo ser classificados desde especialistas à generalistas e, em conjunto, permitem analisar os três ciclos do processo produtivo.

Os casos foram analisados individualmente, procurando consolidar as informações coletadas e ligá-las às proposições, e de forma comparativa, para identificar as semelhanças e diferenças.

A pesquisa partiu de duas premissas que nortearam o estudo e fundamentaram a análise das proposições. Considerando estas premissas como ponto de partida, as proposições foram elaboradas com o objetivo de trazer elementos que permitissem responder às questões de pesquisa. 
Os quadros 10 e 11 resumem os principais resultados verificados na pesquisa. $O$ quadro 10 aborda as premissas e as proposições 1, 2 e 3; enquanto o quadro 11 aborda a proposição 4. Em seguida, todas as proposições foram analisadas frente aos resultados coletados na pesquisa de campo e quanto a validade das proposições. 


\begin{tabular}{|c|c|c|c|c|c|c|c|c|c|}
\hline \multicolumn{10}{|c|}{ Quadro 10 - Principais Resultados (Proposições 1, 2 e 3) } \\
\hline \multirow[t]{3}{*}{$\begin{array}{c}\text { Compreender } \\
\text { como a TI é } \\
\text { utilizada pelos } \\
\text { operadores nos } \\
\text { processos } \\
\text { logísticos }\end{array}$} & $\begin{array}{c}\text { Premissa } 1.1 \\
\text { Identificar o uso } \\
\text { da TI nas } \\
\text { diversas } \\
\text { atividades }\end{array}$ & \multicolumn{2}{|c|}{ Fluxo de Informação e TI } & $\begin{array}{l}\text { Serviço } \\
\text { completo de } \\
\text { terceirização } \\
\text { logística na } \\
\text { exportação e } \\
\text { importação }\end{array}$ & $\begin{array}{l}\text { Aquisição, } \\
\text { armazenagem } \\
\text { e distribuição } \\
\text { dos produtos } \\
\text { para rede fast- } \\
\text { food }\end{array}$ & $\begin{array}{l}\text { ERP, WMS, } \\
\text { TMS, GPS, } \\
\text { Software para } \\
\text { controle e } \\
\text { rastreamento da } \\
\text { carga, Software } \\
\text { para } \\
\text { consolidação da } \\
\text { carga. }\end{array}$ & $\begin{array}{l}\text { Armazenagem, } \\
\text { gestão do } \\
\text { transporte e da } \\
\text { cadeia de } \\
\text { suprimentos e } \\
\text { logística } \\
\text { interna }\end{array}$ & 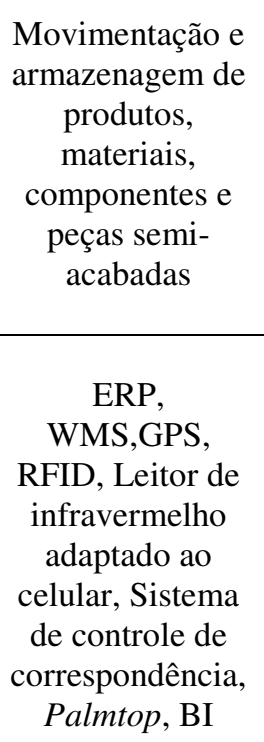 & $\begin{array}{c}\text { As } \\
\text { ferramentas } \\
\text { de TI } \\
\text { utilizadas } \\
\text { variam de } \\
\text { acordo com as } \\
\text { atividades e } \\
\text { serviços } \\
\text { oferecidos } \\
\text { que, por sua } \\
\text { vez, variam } \\
\text { de acordo } \\
\text { com o foco do } \\
\text { operador }\end{array}$ \\
\hline & \multirow{2}{*}{$\begin{array}{c}\text { Premissa } 1.2 \\
\\
\text { Analisar o papel } \\
\text { da TI no } \\
\text { desenvolvimento } \\
\text { das atividades }\end{array}$} & \multirow[t]{2}{*}{$\begin{array}{l}\text { Perspectiva } \\
\text { Interna }\end{array}$} & Alinhamento & $\begin{array}{c}\text { Transformação } \\
\text { Tecnológica }\end{array}$ & $\begin{array}{l}\text { Transformação } \\
\text { Tecnológica }\end{array}$ & $\begin{array}{c}\text { Transformação } \\
\text { Tecnológica }\end{array}$ & $\begin{array}{l}\text { Nível de } \\
\text { serviço }\end{array}$ & $\begin{array}{c}\text { Transformação } \\
\text { Tecnológica }\end{array}$ & $\begin{array}{l}\text { De forma } \\
\text { geral a TI está } \\
\text { alinhada ao } \\
\text { negócio }\end{array}$ \\
\hline & & & $\begin{array}{c}\text { Grid } \\
\text { Estratégico }\end{array}$ & Fábrica & Estratégico & Estratégico & Fábrica & Estratégico & $\begin{array}{c}\text { Impacto } \\
\text { presente em } \\
\text { todos e futuro } \\
\text { em três deles }\end{array}$ \\
\hline
\end{tabular}




\begin{tabular}{|c|c|c|c|c|c|c|c|c|c|}
\hline Objetivos & Premissa 1 & \multicolumn{2}{|c|}{ Elementos de análise } & OL 1 & OL 2 & OL 3 & OL 4 & OL 5 & Conclusão \\
\hline \multirow{6}{*}{$\begin{array}{l}\text { Compreender } \\
\text { como a TI é } \\
\text { utilizada pelos } \\
\text { operadores nos } \\
\text { processos } \\
\text { logísticos }\end{array}$} & $\begin{array}{c}\text { Premissa } 1.2 \\
\text { Analisar o papel } \\
\text { da TI no } \\
\text { desenvolvimento }\end{array}$ & Perspectiva & $\begin{array}{l}\text { Complexidade } \\
\text { logística }\end{array}$ & $\begin{array}{l}\text { Clientes com } \\
\text { diferentes } \\
\text { níveis de } \\
\text { complexidade }\end{array}$ & $\begin{array}{l}\text { Um único } \\
\text { cliente com } \\
\text { elevada } \\
\text { complexidade }\end{array}$ & $\begin{array}{l}\text { Clientes com } \\
\text { diferentes } \\
\text { níveis de } \\
\text { complexidade }\end{array}$ & $\begin{array}{l}\text { Clientes com } \\
\text { diferentes } \\
\text { níveis de } \\
\text { complexidade }\end{array}$ & $\begin{array}{c}\text { Clientes com } \\
\text { diferentes níveis } \\
\text { de complexidade }\end{array}$ & $\begin{array}{c}\text { Complexidade } \\
\text { logística } \\
\text { variada }\end{array}$ \\
\hline & das atividades & $\begin{array}{l}\text { Mercado } \\
\text { Atendido }\end{array}$ & $\begin{array}{l}\text { Políticas de } \\
\text { produção }\end{array}$ & $\begin{array}{l}\text { Atua no ciclo } \\
\text { de manufatura } \\
\text { de um único } \\
\text { cliente }\end{array}$ & $\begin{array}{c}\text { Não atua no } \\
\text { ciclo de apoio } \\
\text { à manufatura }\end{array}$ & $\begin{array}{l}\text { Atua no ciclo } \\
\text { de apoio à } \\
\text { manufatura de } \\
\text { três clientes }\end{array}$ & $\begin{array}{l}\text { Atua no ciclo } \\
\text { de apoio à } \\
\text { manufatura de } \\
\text { diversos } \\
\text { clientes }\end{array}$ & $\begin{array}{l}\text { Atua no ciclo de } \\
\text { apoio à } \\
\text { manufatura de } \\
\text { diversos clientes }\end{array}$ & $\begin{array}{l}\text { OL } 3, \text { OL } 4 \text { e } \\
\text { OL } 5 \text { atuam } \\
\text { no ciclo de } \\
\text { apoio à } \\
\text { manufatura }\end{array}$ \\
\hline & Proposições & \multicolumn{2}{|c|}{ Elementos de análise } & OL 1 & OL 2 & OL 3 & OL 4 & OL 5 & Conclusão \\
\hline & Proposição 1 & \multicolumn{2}{|c|}{$\begin{array}{l}\text { Customização dos } \\
\text { aplicativos }\end{array}$} & Sim & Sim & Sim & $\begin{array}{l}\text { Sim, mas para } \\
\text { se adequar ao } \\
\text { WMS mundial }\end{array}$ & Sim & Aceita \\
\hline & Proposição 2 & \multicolumn{2}{|c|}{$\begin{array}{l}\text { Complexidade logística } \\
\text { versus setor de atuação }\end{array}$} & $\begin{array}{c}\text { Não existem } \\
\text { diferenças } \\
\text { entre os } \\
\text { setores }\end{array}$ & $\begin{array}{l}\text { Não existem } \\
\text { elementos para } \\
\text { análise }\end{array}$ & $\begin{array}{l}\text { Não existem } \\
\text { diferenças entre } \\
\text { os setores }\end{array}$ & $\begin{array}{l}\text { Não existem } \\
\text { diferenças } \\
\text { entre os } \\
\text { setores }\end{array}$ & $\begin{array}{l}\text { Não existem } \\
\text { diferenças entre } \\
\text { os setores }\end{array}$ & Refutada \\
\hline & Proposição 3 & \multicolumn{2}{|c|}{$\begin{array}{l}\text { Políticas de produção versus } \\
\text { Papel da TI }\end{array}$} & $\begin{array}{l}\text { Não existem } \\
\text { elementos para } \\
\text { análise }\end{array}$ & $\begin{array}{l}\text { Não existem } \\
\text { elementos para } \\
\text { análise }\end{array}$ & $\begin{array}{l}\text { Importância da } \\
\text { TI é a mesma }\end{array}$ & $\begin{array}{l}\text { Importância da } \\
\text { TI é a mesma }\end{array}$ & $\begin{array}{l}\text { Importância da } \\
\text { TI é a mesma }\end{array}$ & Refutada \\
\hline
\end{tabular}

Fonte: elaborada pelo autor (2008). 


\subsection{Questão 1 - Como a TI é utilizada pelos operadores no processo logístico?}

Para responder a primeira questão de pesquisa foram mapeados os fluxos de materiais, produtos e informação entre os agentes da cadeia; identificadas as ferramentas de TI em cada área do trabalho logístico e, dentro de cada área, nas diversas atividades (Premissa 1.1). Finalmente, estes aplicativos foram analisados no desenvolvimento do processo logístico pelo operador (perspectiva interna) e no atendimento das necessidades dos clientes (perspectiva do mercado atendido) (Premissa 1.2).

O desenvolvimento da Premissa 1.1 e da primeira parte da Premissa 1.2 (perspectiva interna) são necessários para análise da Proposição 1. E o desenvolvimento da segunda parte da Premissa 1.2 (perspectiva do mercado atendido) é necessário para análise das Proposições 2 e 3.

Quanto à identificação do uso da TI nas diversas atividades (Premissa 1.1), foram encontrados três sistemas de apoio à área operacional. São eles: sistemas ERP que apóiam a parte fiscal e de documentação dos processos logísticos, sistemas para gestão dos armazéns (WMS) e, com menor freqüência, sistemas para gestão de transporte (TMS).

Outras tecnologias importantes para o processo logístico são as embarcadas nos caminhões. Destacou-se o Sistema de Posicionamento Global (GPS) para realização da roteirização e do rastreamento dos caminhões ou, no caso de OL 5, dos veículos. O roteirizador não é utilizado por todos os operadores. Foi ressaltada sua importância quando há constantes mudanças ou imprevisibilidade nas rotas de entrega.

Os equipamentos utilizados para receber o sinal dos satélites variaram de um operador para outro. OL 2 utiliza Palmtop, OL 3 o computador de bordo e, OL 5, o celular. Outras tecnologias encontradas foram: software para segurança das cargas e RFID para monitoramento e rastreamento de caminhões dentro de um CD.

As tecnologias empregadas pelos agentes nos processos operacionais são as mesmas. As diferenças ocorrem nos dispositivos para captura das informações e nas tecnologias que operam ao redor do WMS, TMS e do ERP. Estas vão além do apoio às atividades operacionais e trazem diferenciação para o processo logístico. São sistemas de informação customizados, voltados para atender as necessidades específicas de cada negócio.

Podem ser incluídos nesta categoria o sistema de apoio à exportação e importação de OL 1; o "Sistema Órbita" desenvolvido por OL 2; e o leitor de infravermelho e o sistema de controle e gestão da correspondência interna desenvolvidos por OL 5. Não há inovação 
significativa no Sistema Fiscal de OL 4 pois, na verdade, substitui funções que poderiam ser executadas por um sistema ERP.

Outra ferramenta utilizada por alguns dos operadores pesquisados são os softwares de Business Intelligence. A partir dos dados, os operadores compilam relatórios que dão suporte nas previsões, análises e na tomada de decisão.

Finalmente, verificou-se que estão em implantação um novo módulo do "Sistema Órbita" (VMI) para a integração dos fornecedores da rede fast-food e um software para consolidação das cargas nos caminhões de OL 3.

Pode-se constatar que as ferramentas de TI utilizadas variaram de acordo com as atividades e serviços oferecidos que, por sua vez, variaram de acordo com o foco do operador. OL 3 realiza armazenagem e possui um WMS. Como não atua na gestão do transporte, não utiliza TMS. OL 1, voltado para o desenvolvimento do processo logístico internacional, não possui armazéns e não faz gestão do transporte. Conseqüentemente, não utiliza soluções WMS e TMS. TMS é utilizado somente pelos operadores que realizam a gestão do transporte, como OL 3 e OL 4.

Mas, a realização das atividades de armazenagem e transporte de modo eficiente não é fator de diferenciação para os operadores. Estas atividades foram consideradas pelos operadores entrevistados como commodities. Sua execução de modo eficiente, por si só, não trás vantagens competitivas.

Quanto à análise do papel da TI no desenvolvimento das atividades dos operadores (Premissa 1.2), foram avaliadas as metas destes agentes, a ocorrência de alinhamento entre estratégia do negócio e das tecnologias e, finalmente, a importância das aplicações de TI no presente e no futuro.

Todos os operadores têm com meta atingir a flexibilidade - capacidade para se adequar a diferentes situações e parceiros - e eficácia - adicionar o máximo de valor ao processo logístico por meio de qualidade e diferenciação. A TI vem desempenhando um papel central.

Mas, para que a TI contribua para a competitividade do processo logístico é necessário haver alinhamento entre a estratégia do negócio e da tecnologia (HENDERSON; VENKATRAMAN, 1993). Com uma única exceção - OL 4 - a estratégia do negócio determinou a estratégia de TI adotada pelos operadores e, conseqüentemente, exigiu o estabelecimento de infra-estrutura de TI e processos adequados. No caso de OL 4, como a empresa adota o mesmo sistema em todo o mundo, tem menos flexibilidade para modificações em suas ferramentas. 
OL 1, OL 2, OL 3 e OL 5 enquadram-se, portanto, no alinhamento denominado por Henderson e Venkatraman (1993) de “Transformação Tecnológica”. Neste alinhamento estratégico, a TI pode ser avaliada pelo que adicionou ao produto ou serviço final da empresa. No caso de OL 1 permitiu a diferenciação do seu serviço e ampliação do escopo de atuação garantindo a integração entre o operador e seu parceiro "A". Para OL 2 permitiu o desenvolvimento do processo logístico de seu cliente de modo mais eficiente e eficaz, oferecendo novos serviços e realizando as atividades de novas formas. Para OL 3, vem viabilizando a estratégia do negócio e contribuindo para uma maior segurança das cargas. E, finalmente, para OL 5 vem apoiando o desenvolvimento de processos logísticos diferenciados.

Finalmente, analisando a importância das aplicações de TI presentes e futuras, pode-se concluir que as aplicações atuais vêm contribuindo para o desempenho de todos os operadores. As tecnologias são, entretanto, mais estratégicas para OL 2, OL 3 e OL 5 já que estão previstas a implantação de novas aplicações nas três empresas. Em OL 1 e OL 4, no horizonte de planejamento considerado pelos entrevistados, não foram identificadas pressões por novas aplicações de TI, estando previstas apenas atualizações do sistema (MCFARLAN, 1984).

\subsubsection{Análise da Proposição 1}

Considerando o exposto acima sobre a primeira questão de pesquisa, passa-se a verificar a Proposição 1 nos casos analisados.

\section{Proposição 1 - Para que o operador logístico torne-se flexível e atinja a eficácia é necessário o desenvolvimento de aplicativos customizados que atendam suas particularidades e garantam alinhamento entre os fatores externos $\mathrm{e}$ internos (BOWERSOX; DAUGHERTY, 1995; HENDERSON; VENKATRAMAN, 1993).}

No setor logístico agilidade e custo são fatores extremamente importantes, o que significa oferecer o melhor serviço possível para um dado custo (excelência logística). Portanto, além de uma gestão eficiente dos fluxos e estoques; os operadores procuram se diferenciar por meio do desenvolvimento de processos e da disponibilização das informações para seus clientes (BOWERSOX; CLOSS, 2001; BOWERSOX; CLOSS; STANK, 1999). 
Todos os operadores pesquisados têm como objetivo atingir maior eficiência na gestão dos fluxos e armazenagem dos produtos para reduzir custos. A TI atende este objetivo. Houve consenso entre os entrevistados que a TI contribui para a racionalização das tarefas e na sincronização das atividades, resultando em maior eficiência.

Mas, o emprego das tecnologias, por si só, não constitui fator de diferenciação: as tecnologias estão disponíveis e podem ser utilizadas por qualquer empresa. Todos os entrevistados concordaram com relação a este aspecto. Além de uma gestão eficiente dos fluxos e estoques, os operadores devem buscar um posicionamento estratégico que permita desenvolver operações logísticas diferenciadas, com maior valor agregado (BOWERSOX; CLOSS, 2001; BOWERSOX; CLOSS; STANK, 1999).

A vantagem competitiva vem do emprego da TI para o desenvolvimento de operações logísticas diferenciadas, com maior valor agregado. Assim, é importante compreender o negócio para utilizar a TI de forma eficaz, explorando todo o potencial da tecnologia para gerar vantagens competitivas.

Todos os operadores pesquisados buscavam, além de oferecer serviços padronizados, desenvolver soluções logísticas diferenciadas para seus clientes. O diferencial está na criação dos processos, no estabelecimento de métodos para cada tipo de operação, e na definição das tecnologias que serão adotadas para apoiá-los. Estas soluções contribuem para o desenvolvimento de operações logísticas diferenciadas, permitindo aos operadores ganhar mercado, bem como gerar novos produtos e criar novos negócios.

Há dois anos, OL 2 ampliou seu mercado de atuação e passou a operar a logística de seu cliente em toda a América Latina graças as soluções de TI implementadas. Dentre as soluções, destaca-se o "pedido via web". Este sistema foi tão bem sucedido, que está sendo adotado pelos operadores logísticos de Porto Rico, Panamá, Costa Rica, e Guatemala.

A rede fast food do México também vem mostrando interesse em adquirir o sistema e existe uma possibilidade concreta de que venha a ser adotado pela rede em todo o mundo. As oportunidades abertas pelo desenvolvimento de soluções vêm tornando a TI tão importante que, no futuro, pode se transformar em uma nova unidade de negócios.

No caso de OL 3, O WMS desenvolvido para a gestão de seus armazéns está sendo utilizado no abastecimento de linhas de produção e vai ser adotado como padrão pela empresa em outros países.

As soluções desenvolvidas por OL 5, como o leitor de infravermelho acoplado ao aparelho celular e o sistema de gestão de correspondência, vêm trazendo novos clientes e possibilitando o desenvolvimento de novos negócios. 
Muitas vezes, o atendimento às necessidades dos clientes exige o desenvolvimento de novos sistemas. É o caso de OL 5 na distribuição da correspondência interna de uma editora. E de OL 2 com o "pedido via web" e o "gerenciador de campanha". A diferenciação vem da capacidade destes agentes para desenvolver ferramentas de TI inovadoras e com potencial para melhorar as operações logísticas dos clientes.

Finalmente, os operadores entrevistados concordaram que as soluções de prateleira, de forma geral, não atendem aos seus negócios. Isto pôde ser constatado tanto nos softwares de apoio à operação - foram adquiridos no mercado, mas sofreram intenso processo de customização e, atualmente, guardam poucas características da versão original -, como também da necessidade do desenvolvimento de sistemas de informação para apoiar as particularidades do negócio de cada operador.

Esta análise indica que a Proposição 1 deve ser aceita no que diz respeito aos processos internos dos operadores. De fato, para que o operador logístico torne-se flexível e atinja a eficácia é necessário o desenvolvimento de aplicativos customizados que atendam suas particularidades e garantam alinhamento entre os fatores externos e internos. Já com relação à tecnologia embarcada nos caminhões houve clara preferência pela aquisição de pacotes de mercado.

\subsubsection{Análise das Proposições 2 e 3}

A investigação das Proposições 2 e 3 apoiou-se na segunda parte da Premissa 1.2 (perspectiva do mercado atendido).

\section{Proposição 2 - A complexidade logística e, portanto, a necessidade de aplicações de TI, são determinadas pelas características do setor.}

Dois aspectos foram analisados: relação entre as tecnologias e o setor de atuação dos clientes, e sua adequação a política de produção dos clientes.

- Quanto a complexidade logística decorrente das características do setor.

Foi constatado que quanto maior a complexidade logística do negócio, maior a necessidade de aplicações de TI (BOWERSOX; CLOSS, 2001). O abastecimento de mais de mil pontos de venda da rede fast-food foi simplificado e diminuiu a incidência de erros com a implantação do "pedido via web" por OL 2. Ou o atendimento de uma elevada movimentação 
de itens para atender operações de varejo online, por exemplo, exigiu de OL 3, para um maior controle de seus armazéns, a implantação de WMS.

A complexidade logística, entretanto, não está diretamente relacionada ao setor de atuação da empresa: é possível encontrar em um mesmo setor, empresas com diferentes níveis de complexidade. No setor de alimentos, por exemplo, o abastecimento dos restaurantes da rede fast food tem maior complexidade logística do que de uma rede de restaurantes com poucas unidades e mais concentrada geograficamente. Ou a distribuição de produtos eletroeletrônicos para o cliente final, com muitos pedidos de pequenos volumes, tem maior complexidade logística do que a distribuição para as lojas de varejo, que realiza poucos pedidos com grande volume.

Em qualquer setor, o processo logístico é o mesmo e, portanto, utiliza as mesmas aplicações de TI. Foi constatado mudanças nas necessidades dos clientes em decorrência de características do negócio. $\mathrm{O}$ operador customiza as ferramentas para atender as particularidades de cada negócio, oferecendo ao cliente as informações desejadas no formato adequado.

O setor de fármacos, por exemplo, exige cuidados especiais no manuseio dos produtos: os volumes são pequenos, têm alto valor agregado, os prazos de vencimento são críticos, utiliza embalagens especiais, etc.

Concluindo, a Proposição 2 foi refutada em todos os cinco casos analisados. Embora uma maior complexidade logística aumente a necessidade do uso de aplicações de TI, ela não está relacionada às características do setor.

\section{Proposição 3 - Se a produção está baseada nas vendas efetivamente realizadas (pull) o papel desempenhado pela TI é mais importante do que quando está baseada na expectativa de vendas (push).}

Quando a política de produção, houve concordância entre os entrevistados quanto à necessidade de articulação e coerência entre o trabalho logístico e a política de produção dos clientes. Mas, todos refutaram a idéia de que o papel desempenhado pela TI é mais importante quando a produção é baseada na expectativa de vendas do que quando se baseia nas vendas efetivamente realizadas (CHANDRACHEKAR; SCHARY, 1999). Para eles, a TI é igualmente importante nas duas políticas de produção, esteja ela baseada na demanda histórica ou na demanda gerada. Portanto, considerando os casos analisados, a Proposição 3 deve ser refutada. 
Concluindo, quanto à primeira questão deste estudo - como a TI é utilizada pelos operadores no processo logístico - a pesquisa mostrou a importância dos aplicativos customizados para estes agentes nos casos estudados. $\mathrm{O}$ desenvolvimento de aplicativos capazes de atender as particularidades de cada operador e de garantir o alinhamento entre os fatores externos e internos mostrou-se fundamental para a flexibilidade e eficácias destes agentes. A pesquisa conclui, ainda, que a utilização da TI nos processos logísticos não está relacionada às características dos diferentes setores e nem com as diferentes políticas de produção.

\subsection{Questão 2 - Como a TI contribui para o estabelecimento das redes de valor?}

Para responder a segunda questão de pesquisa foram investigados três elementos: (i) níveis de integração existentes entre os agentes, (ii) existência ou não de coordenação dos fluxos de materiais, produtos e informação e o agente coordenador, e (iii) as parcerias estabelecidas. Finalmente, buscou-se identificar as redes de valor, onde ocorre compartilhamento de informação e colaboração total entre os agentes. O quadro 11 resume os principais resultados (Proposição 4) necessários para responder a segunda questão de pesquisa. 
Quadro 11 - Principais Resultados (Proposição 4)

\begin{tabular}{|c|c|c|c|c|c|c|c|c|}
\hline Objetivos & Proposição 4 & Elementos de análise & OL 1 & OL 2 & OL 3 & OL 4 & OL 5 & Conclusão \\
\hline \multirow{4}{*}{$\begin{array}{l}\text { Compreender } \\
\text { como a TI } \\
\text { contribui para o } \\
\text { estabelecimento } \\
\text { das redes de } \\
\text { valor? }\end{array}$} & \multirow{3}{*}{$\begin{array}{l}\text { A TI está na } \\
\text { base da gestão } \\
\text { integrada da } \\
\text { logística }\end{array}$} & Integração & $\begin{array}{l}\text { Plena com } \\
\text { parceiro "A" e } \\
\text { com alguns } \\
\text { clientes }\end{array}$ & $\begin{array}{l}\text { Plena com } \\
\text { cliente e com } \\
\text { clientes dos } \\
\text { clientes. } \\
\text { Parcial com } \\
\text { fornecedores, } \\
\text { mas evoluindo } \\
\text { para plena }\end{array}$ & $\begin{array}{l}\text { Plena com } \\
\text { clientes e } \\
\text { transportadoras }\end{array}$ & $\begin{array}{l}\text { Níveis } \\
\text { variados. } \\
\text { Tem } \\
\text { capacidade } \\
\text { para } \\
\text { estabelecer } \\
\text { plena }\end{array}$ & $\begin{array}{l}\text { Não há } \\
\text { integração }\end{array}$ & \multirow{3}{*}{$\begin{array}{l}\text { Identificados } \\
\text { três níveis de } \\
\text { integração: } \\
\text { plena, parcial } \\
\text { e inexistente. } \\
\text { O papel da TI } \\
\text { é central na } \\
\text { integração } \\
\text { plena e parcial }\end{array}$} \\
\hline & & Coordenação & $\begin{array}{c}\text { Operador } \\
\text { Logístico "A" }\end{array}$ & OL 2 & Cliente & Cliente & - & \\
\hline & & Parcerias & $\begin{array}{c}\text { Operador } \\
\text { Logístico "A" }\end{array}$ & Rede fast-food & Transportadoras & - & & \\
\hline & $\begin{array}{c}\text { A gestão } \\
\text { integrada da } \\
\text { logística está na } \\
\text { base das redes } \\
\text { de valor }\end{array}$ & $\begin{array}{c}\text { Colaboração e } \\
\text { compartilhamento total de } \\
\text { informações }\end{array}$ & $\begin{array}{l}\text { Ocorre em } \\
\text { segmentos }\end{array}$ & $\begin{array}{l}\text { Ocorre em } \\
\text { segmentos. } \\
\text { Caso mais } \\
\text { próximo de } \\
\text { rede de valor. }\end{array}$ & $\begin{array}{l}\text { Ocorre em } \\
\text { segmentos }\end{array}$ & $\begin{array}{l}\text { Ocorre em } \\
\text { segmentos }\end{array}$ & - & $\begin{array}{l}\text { Identificados } \\
\text { segmentos de } \\
\text { rede de valor }\end{array}$ \\
\hline
\end{tabular}

Fonte: elaborado pelo autor (2008). 


\subsubsection{Análise da Proposição 4}

Proposição 4 - a TI está na base da gestão integrada da logística. E a gestão integrada da logística está na base do estabelecimento das redes de valor.

A figura 29 detalha como os diversos operadores estudados estão integrados a outros agentes da rede.

Figura 32 - Integração entre operadores e outros agentes da rede

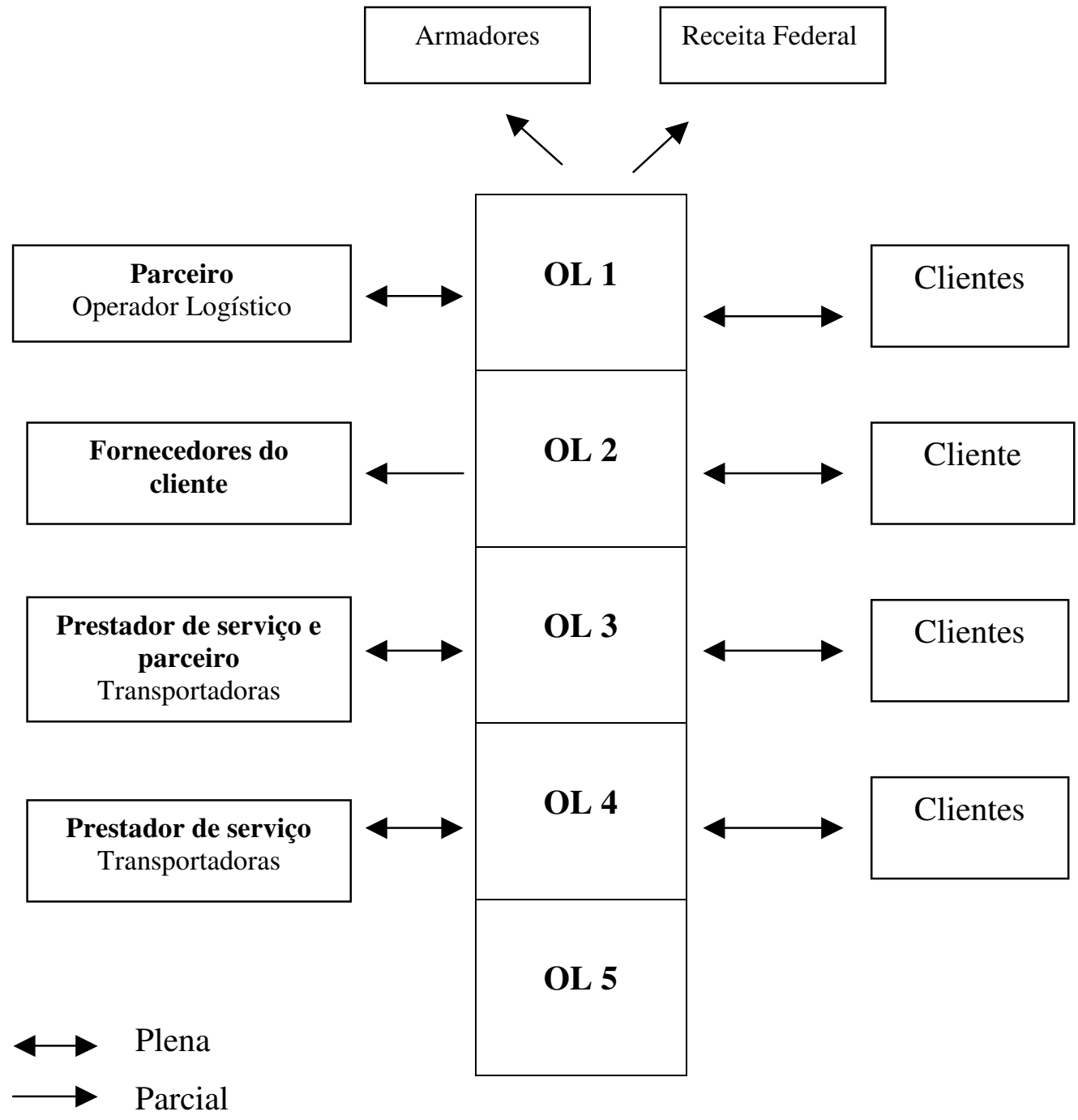

Fonte: elaborado pelo autor (2008).

Foram identificados três níveis de integração entre o operador logístico e os demais agentes: plena, parcial e inexistente. A integração é plena quando há compartilhamento total 
de informações entre os agentes, parcial quando somente um dos agentes acessa e atualiza as informações no banco de dados do outro agente e, finalmente, inexistente quando não há troca de informação por meio eletrônico.

- OL 1 está plenamente integrado ao seu parceiro, operador logístico "A" e pode estar plenamente integrado aos seus clientes. Mantém integração parcial com os armadores e com a Receita Federal, uma vez que só o operador tem acesso ao banco de dados destes agentes. A coordenação da rede cabe ao parceiro "A" ou aos clientes que também estabelecem os parâmetros e regulamentações.

- OL 2 é um caso bastante particular. Além de executar a coordenação da rede, está plenamente integrado a seu único cliente - a rede fast food - e clientes do cliente - as lojas de rede. No momento vem buscando a integração com os fornecedores de seu cliente. A codificação de material, regulamentação e determinação dos preços são estabelecidas pela rede fast food.

- OL 3 está plenamente integrado às transportadoras, até por que toda a tecnologia embarcada nos caminhões é disponibilizada pelo operador, e tem capacidade para manter integração plena com seus clientes. A coordenação e o estabelecimento de parâmetros e regulamentações são realizados pelos clientes.

- OL 4 tem capacidade para manter integração plena com clientes e com as transportadoras de acordo com o nível tecnológico e o interesse destes agentes. A coordenação e o estabelecimento de parâmetros e regulamentações são realizados pelos clientes.

- OL 5 não mantém integração com seus clientes e nem com outros agentes. Este operador atua exclusivamente na logística interna. A coordenação do ciclo logístico interno e o estabelecimento de parâmetros e regulamentações são realizados pelos clientes.

As redes de valor são estabelecidas pela integração plena entre fornecedores dos clientes, clientes, clientes dos clientes e agentes de apoio. Exigem, ainda, coordenação dos agentes e o estabelecimento de parcerias. Nos casos estudados, entretanto, foi encontrada integração plena somente entre alguns agentes. A coordenação e o estabelecimento de parcerias, com exceção de OL 2, vêm sendo desenvolvida pelos clientes.

Assim, os agentes da rede de OL 2, por suas particularidades, são os que mais se aproximam de uma rede de valor. OL 5, por executar logística interna, não pode sequer ser incluído nesta classificação. Os demais operadores - OL 1, OL 3, OL 4 - não puderam ser classificados como rede por não estarem plenamente integrados a todos os agentes.

Portanto, em relação à Proposição 4, ela deve ser parcialmente aceita, pois foram identificados três níveis de integração: plena, parcial e inexistente e o papel da TI é central na 
integração plena e parcial. No que se refere à gestão integrada da logística como base das redes de valor, foram identificados segmentos de rede de valor, mas não em todos os casos estudados.

Concluindo, quanto à segunda questão de pesquisa - como a TI contribui para o estabelecimento das redes de valor - a pesquisa mostrou que a TI contribui para a formação de redes de valor por meio da integração entre os agentes envolvidos no processo logístico.

\subsection{Propostas de um modelo para identificação dos níveis de integração externa entre os agentes}

Há várias referências na literatura ao caráter evolutivo inerente ao processo de integração (BOWERSOX, 1989, VENKATRAMAN, 1994, STEVENS, 1989). Mas não há, nestes autores, uma caracterização das etapas envolvidas na integração externa.

Stevens (1989), por exemplo, classificou a integração interna em três níveis que evoluem para o quarto e último nível onde a integração da cadeia de suprimentos é completa, envolvendo clientes, fornecedores e outros parceiros. Mas, não há um detalhamento das etapas que compõem o quarto nível.

No estudo de casos, os operadores entrevistados atuam estabelecendo elos entre os fornecedores de seus clientes, os próprios clientes e os clientes dos clientes. E, para executar suas atividades, utilizam agentes de apoio, tais como empresas de transportes (próprias ou terceirizadas), outros operadores logísticos, desenvolvedores de softwares, despachantes aduaneiros, etc. Em alguns casos ocorreu o estabelecimento de parcerias.

A figura 33 indica os diferentes níveis da integração externa entre os operadores e os agentes encontrados na pesquisa. 
Figura 33 - Agentes e níveis de integração externa dos operadores estudados

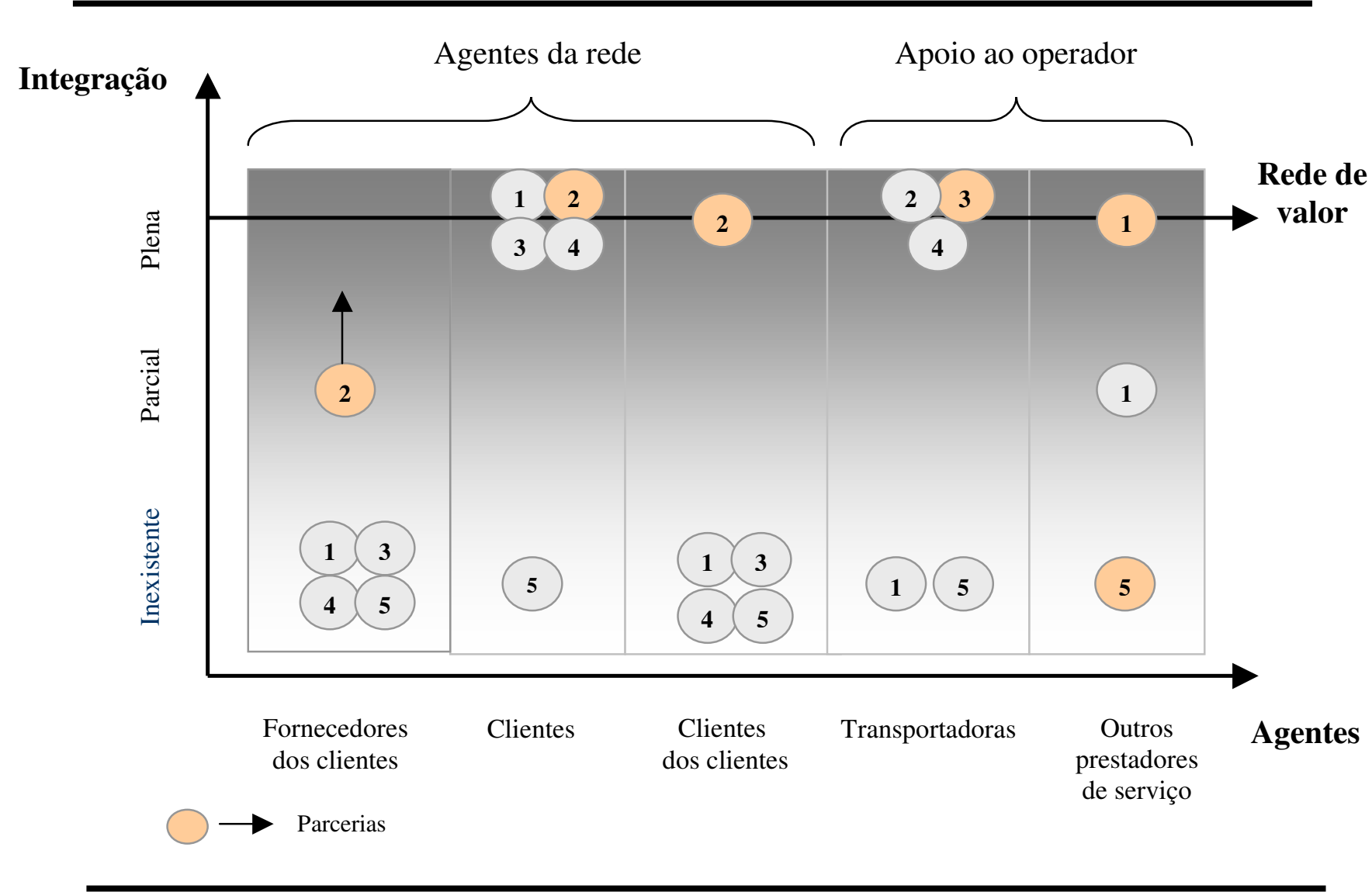

Fonte: Elaborado pelo autor (2008).

Com relação aos agentes da rede:

- OL 1, OL 2, OL 3 e OL 4 estão integrados ou tem capacidade para se integrar plenamente aos seus clientes.

- OL 2 está integrado aos clientes do seu cliente, mantém integração parcial com os fornecedores de seus clientes e está implantando um novo módulo no sistema que permitirá a integração plena com estes agentes.

Com relação aos agentes de apoio:

- OL 2, OL 3 e OL 4 mantêm integração plena com as transportadoras ressaltando que, no caso de OL 2, é proprietário.

- OL 1 está plenamente integrado ao seu parceiro "A" e parcialmente aos embarcadores e Receita Federal. OL 5 tem parceira com um desenvolvedor de softwares, mas não está integrado a este agente. Não foi citada nas entrevistas com os demais operadores a participação de outros prestadores de serviço.

Com relação ao estabelecimento de parcerias: 
- OL 1 mantém parceria com um grande operador logístico - "A" -, OL 2 com todos os agentes da rede (fornecedores, clientes e clientes dos clientes), OL 3 com as empresas de transporte e, finalmente, OL 5 é parceiro de uma empresa desenvolvedora de softwares.

Embora a integração plena e o estabelecimento de parcerias estejam limitados a alguns agentes, os segmentos onde ocorre podem ser caracterizados como rede de valor. Nestes segmentos de rede, os fluxos e estoques são administrados como um processo, ocorrendo a sincronização das diversas atividades operacionais e agregando valor para todos os agentes envolvidos. É o caso de OL 1, seus clientes e o parceiro “A”; OL 3, seus clientes e as transportadoras; e OL 4, seus clientes e as transportadoras.

\subsection{Recomendações para novos estudos}

Pelas limitações inerentes ao método utilizado - estudo de casos - este trabalho não se propõe a realizar generalizações conclusivas sobre o assunto. O objetivo era explorar e descrever os casos pesquisados e verificar de que forma permitem responder as perguntas propostas. As considerações finais, portanto, só se aplicam ao universo dos casos estudados.

A estrutura utilizada para análise dos casos baseou-se em ampla revisão bibliográfica. A revisão permitiu identificar elementos que deveriam ser explorados e autores com as abordagens mais adequadas aos objetivos da pesquisa. A estrutura desenvolvida pode ser utilizada em novos estudos de caso que pretendam investigar o uso da TI nos operadores logísticos.

O estudo dos casos permitiu, ainda, a apresentação e uma proposta de uma caracterização dos níveis de integração externa entre os operadores logísticos e os demais agentes da rede (figura 33), onde se procurou reunir os vários elementos identificados na revisão bibliográfica e na pesquisa de campo.

A caracterização proposta pode ajudar na localização e análise de segmentos de redes e, sobretudo, indicar a evolução destas estruturas em direção a uma rede de valor. Não pretende, contudo, ser uma proposta definitiva, mas apenas uma compilação dos resultados que pode dar elementos para novas pesquisas. Seriam necessárias novas pesquisas para verificar a relação de causa e efeito entre o uso da TI e o estabelecimento de redes de valor quando ocorre integração parcial ou plena.

Neste sentido, estudos voltados para o entendimento das redes em diferentes setores podem contribuir para a verificação da validade e aderência da caracterização proposta, assim como ajudar na identificação de novos elementos que a tornem mais abrangente. 
É importante ressaltar que o desenvolvimento de estudos apoiados no conceito de rede exige a identificação dos elementos estruturais (agentes, ligações, critérios de agrupamento e definição de seus limites) e análise de como estes elementos estão combinados (BRITTO, 2002).

A análise global da rede, entretanto, deve sempre partir de uma empresa foco. Isto porque cada agente tem um tipo de inserção, está ligado a diferentes parceiros por diferentes processos e pode participar de diversas cadeias. Assim, cada empresa vê a rede a partir da sua própria perspectiva (COOPER; LAMBERT; PAGH, 1997).

A pesquisa identificou, ainda, alguns aspectos interessantes e que podem ser melhor explorados em pesquisas futuras:

- De acordo com os operadores entrevistados, os clientes desejam obter serviços de alto nível com o menor custo possível. O acesso a novos processos, idéias e tecnologias também foi apontado de forma recorrente como um dos fatores de diferenciação.

- Os operadores vêm contribuindo para a disseminação da tecnologia para os outros agentes. OL 2, por exemplo, vem introduzindo novas soluções para seu cliente e também para seus fornecedores; OL 3 para seus fornecedores e parceiros - as transportadoras - e, OL 5; para seus clientes.

Outro campo bastante promissor e pouco estudado é a logística no setor de serviços: este setor é bastante complexo, inclui atividades diversificadas e com características específicas. Suas complexidades e particularidades tornam seu processo logístico bastante peculiar e com grande potencial para o desenvolvimento de inovações, tanto nos processos como nas tecnologias empregadas. Assim, podem ser de grande valor pesquisas que ajudem a compreender a logística neste setor em suas inúmeras dimensões, visando estruturar e desenvolver conceitos e metodologias (VILLELA; LIMA JR, 2006).

Finalmente, cabe ressaltar a carência - tanto no Brasil como no exterior - de estudos abordando aspectos específicos do setor logístico e, mais ainda, de pesquisas explorando questões a partir do ponto de vista dos operadores. A maioria dos trabalhos fornece uma visão ampla do setor e tem foco nos seus usuários (MALONI; CARTER, 2006).

A carência de pesquisas com estas abordagens aponta possibilidades para 0 desenvolvimento de novos estudos, entre eles, pesquisas voltadas para o entendimento dos processos logísticos em uma indústria em particular, para a análise dos serviços logísticos e abordando tópicos específicos, como características dos negócios, particularidades dos produtos e dos operadores logísticos, e o papel das tecnologias para estes agentes e para os processos logísticos. Inserem-se nesta linha pesquisas buscando compreender quais as 
ferramentas de TI utilizadas no Brasil pelos operadores logísticos (survey) e como atuam as empresas desenvolvedoras de aplicativos para o setor logístico (estudo de casos). 


\section{REFERÊNCIAS BIBLIOGRÁFICAS}

ABRANCZUK, A.A.: Os Relacionamentos na Cadeia de Suprimentos sob o Paradigma da Desintegração Vertical de Processos: um estudo de caso, 2001, Dissertação (Mestrado), Escola Politécnica, USP, São Paulo, 2001.

ALLEN, N.: “Ten Years on”, Logistics Europe, v. 11, n 1, p. 29-32, Jan/fev 2003.

APPLEGATE, L.; AUSTIN, R.; MCFARLAN, F.: Corporate Information Strategy and Management, 6th ed. McGraw-Hill, 2003.

AROSO, R.: "Software de Supply Chain Management: definições e principais funcionalidades”, <http://www.centrodelogistica.com.br/new/fs-bibliografia.htm>, 2003. Acesso em: 10 de outubro de 2006.

ASHENBAUM, B.; MALTZ, A.B.; RABINOVICH, E.: "Studies of Trends in Third-Party Logistics Usage: What Can We Conclude?", Transportation Journal, v. 44, n 3, p. 39-50, 2005.

ASSUMPÇÃO, M.R.P.: "Reflexão para a Gestão Tecnológica em Cadeias de Suprimentos", Revista Gestão e Produção, v.10, n.3 p. 345-361, dezembro 2003.

BADE, D.J.; MUELLER, J.K.: "New for the Millennium: 4PL", Transportation and Distribution, v. 40, p.78-80, 1999.

BALlOU, R.H.: Gerenciamento da Cadeia de Suprimentos: planejamento, organização e logística empresarial, Porto Alegre: Bookman, $4^{\mathrm{a}}$ edição, 2001.

BALLOU, R.H.: "The Evolution and Future of Logistics and Supply Chain Management" European Business Review, vol. 19; nº, p. 332 - 348, 2007.

BARROS, M.C.: "WMS no Gerenciamento de Depósitos, Armazéns e Centros de distribuição", Boletim Informativo - gestão e tecnologia industrial, n. 26, Instituto de Educação Tecnológica, Rio de Janeiro, <http://www.ietec.com.br/ietec/cursos/area_gestao_e_tec_industrial/2005/08/04/2005_08_04 _0001.2xt/materia_clipping/2005_08_04_0164.2xt/dtml_boletim_interna>. Acesso em: 03 de março de 2004.

BENBASAT, D.K.; GOLDSTEIN, M.: "The Case Research Strategy in Studies of Information Systems", MIS Quartely, v. 11 n 3, p. 369-386, 1987. 
BERGLUND, M.: Third-party Logistics Providers towards a Conceptual Strategic Model, Tek. Lic. Thesis No. 642, Linköping University, 1997.

BERGLUND, M; VAN LAARLOVEN, P.; SHARMAN, G.; WANDEL, S.: “Third-party Logistics: is there a future?" International Journal of Logistics Management; v. 10, $\mathrm{n}^{\mathrm{o}} 1$, p. 59-70, 1999.

BERTO, R.M.V.S.; NAKANO, D.N.: "Metodologia de Pesquisa e a Engenharia da Produção", in XVIII Encontro Nacional de Engenharia de Produção (ENEGEP) e IV International Congress of Industrial Engenieering (ICIE), Niterói, RJ, 1998.

BOLUMOLE, Y.A.: "The Supply Chain Role of Third-party Logistics Providers", International Journal of Logistics Management; ABI/INFORM Global, v. 12, $\mathrm{n}^{\mathrm{o}} 2$; p. 87, 2001.

BONOMA, T.V.: "Case Research in Marketing: opportunities, problems, and a process", Journal of Marketing Research, v. 22, p. 178 - 193, may 1985.

BOVET, D. ; MARTHA, J.: Redes de valor, São Paulo: Negócio Editora, 2001.

BOWERSOX, D. J.: "Logistics in the Integrated Enterprise", The Annual Conference of the Council of Logistics Management, St. Louis, MO. 1989.

BOWERSOX, J.D.; DAUGHERTY, P.J.: "Logistics Paradigms: the impact of information technology”, Journal of Business Logistics, v. 16, n. 1, p. 65-80, 1995.

BOWERSOX, D.J.; CLOSS, D J.; STANK, T.P.: 21st Century Logistics: making supply chain integration a reality, Oak Brooks: Council of Logistics Management, 1999.

BOWERSOX, J.D.; CLOSS, D.J.: Logística Empresarial: o processo de integração da cadeia de suprimentos, São Paulo: Editora Atlas, 2001.

BOYD, H.W.; WESTFALL, R.: "Pesquisa Mercadológica: texto e casos", São Paulo: Fundação Getúlio Vargas, 1979.

BRITTO, J.: "Cooperação Interindustrial e Redes de Empresas", Economia Industrial: fundamentos teóricos e práticos no Brasil, org. David Kupfer e Lia Hasenclever, Editora Campus, 2002.

BROWN, I.; RUSSEL, J.: "Radio Frequency Identification Techonology: na exploratory Study on Adoption in the South African Retail Sector", International Journal of Information Management, v. 27, $\mathrm{n}^{\circ}$ 4, p. 250 - 265, 2007. 
BRYMAN, A.: Research methods and organization studies, London: Uniwin, 1989.

CARVALHO, M.M.; LAURINDO, F.J.B.: Estratégia para a Competitividade, São Paulo: Editora Futura, 2003.

CHANDRASHEKAR, A.; SCHARY, P.B.: "Toward the Virtual Supply Chain: the convergence of IT and organization”. International Journal of Logistics Management, vol. 10, no 2; p. 27-39, 1999.

CHEN, M., YANG, T., CHIA, H.: "Evaluating the Supply Chain Performance of IT- based Inter-enterprise Collaboration". Information \& Management, vol. 2, nº 44, p. 524 - 534, 2007.

CHIZZOTTI, A.: Pesquisa em ciências humanas e sociais, São Paulo: Editora Cortez, $5^{\text {a }}$ edição 2001.

CHOPRA, S.; MEINDL P.: Supply Chain Management: strategy, planning and operation, New Jersey: Prentice Hall, $4^{\text {a }}$ edição, 2001.

CHOW, G.; GRITTA, R.: "The Growth and Development of the US Third Party Logistics Industry", <http://www.infochain.org/quarterly/Sp02/Chow.html>, 2002. Acesso em: 15 de maio de 2005.

CLAVER, E.; GONZALEZ, R.; LOPES, J.: "An Analysis of Research in Information Systems (1981 - 1997)", Information \& Management, v. 34, nº 7, p. 181-195, 2000.

CLOSS, D.J.; SAVITSKIE, K.: "International and External Logistics Information Techonology Integration". The International Journal of Logistics Management, vol. 14, $\mathrm{n}^{\circ} 1$, p. $63-76,2003$.

COATES, T.T.; MCDERMOTT C.M.: "An Exploratory Analysis of New Competencies: a resource based view perspective", Journal of Operations Management, v.20, nº 5, p. 435-450, 2002.

COHEN, M. A.; MALLIK, S.: "Global Supply Chains: research and applications", Production and Operations Management, v.6, nº.3, p. 193-210, 1997.

COUNCIL OF SUPPLY CHAIN MANAGEMENTE PROFESSIONALS: <http://cscmp.org> COOPER, M. C.; LAMBERT, D. M.; PAGH J.D.: "Supply Chain Management: more than a new name for logistics", The International Journal of Logistics Management, v. 8, $\mathrm{n}^{\circ} .1, \mathrm{p} .1$ $14,1997$. 
CRESWELL, J.W.: Research Design: qualitative and quantitative approaches, London: Sage, 1994.

CRISTOPHER, M.: Logística e Gerenciamento da Cadeia de Suprimentos: estratégias para a redução de custos e melhoria dos serviços, São Paulo: Editora Pioneira, 1997.

CROXTON, K. L.; GARCIA-DASTUGUE, S. J. ; LAMBERT, D. M. ; ROGERS, D. S.: "The Supply Chain Management Process", The International Journal of Logistics Management, v.12, n.2, p.13-36, 2001.

DAVENPORT, T.H.; SHORT J.: "The New Industrial Engineering: information technology and business process redesign", Sloan Management Review, v. 31, n 4, p. 11-27, Summer 1990.

DAVENPORT, T. H.: Reengenharia de Processos, Rio de Janeiro: Editora Campus, 1994.

DAVENPORT, T.H.; BROOKS, D.B.: "Enterprise Systems and the Supply Chain”, Journal of Enterprise Information Management, v. 17, nº 1, p. 8-19, 2004.

DAVIS, T.: "Effective Supply Chain Management", Operations Management and Research, v. 34, nº 4 , p. 35-46, Summer, 1993.

DEMARIA, M.: O Operador de Transporte Multimodal como Fator de Otimização da Logística, Dissertação (Mestrado), Universidade Federal de Santa Catarina, Programa de pósgraduação em Engenharia de Produção, Florianópolis, 2004.

DONOVAN, J.J.: "Beyond Chief Information Officer to Network Manager". Harvard Business Review, v. 66, nº 5, p. 134-140, Sep/Oct, 1988.

DRUCKER, P.: The Essential Drucker, Butterworh-Heinemann, Oxford, UK, 2001.

DURLACHER : Durlacher Research: mobile commerce report, $<$ http://www.durlacher.com/research/res-reports.asp<, 2001. Acesso em: 01 de julho de 2004. EDWARDS, P.; PETERS, M.; SHARMAN, G.: "The Effectiveness of Information Systems in Supporting the Extended Supply Chain”, Journal of Business Logistics, v.22, nº1, p. 1-27, 2001.

EISENHARDT, K.M.: "Building Theories from Case Study Research", Academy of Management Review, v. 14, $\mathrm{n}^{\circ} .4$, p. 532- 550, 1989.

ENNS, S.T.; SUWANRUJI, P.: Distribution Planning and Control: an Experimental Comparison of DRP and Order Point Replenishment Strategies, Dept. of Mechanical and 
Manufacturing Engineering, University of Calgary, Calgary, AB, Canada, <http://www.sba.muohio.edu/abas/2000/P-3722_Enns.pdf>, 2000. Acesso em: 18 de agosto de 2006.

FACHIN, O.: Fundamentos da Metodologia, São Paulo: Editora Saraiva, 2001.

FAWCETT, S.E.; CLINTON, S.R.: "Enhancing Logistics Performance to Improve the Competitiveness of Manufacturing Organizations", Transportation Journal, v. 37, n. 1, p. 1828, Arlington, 1997.

FIGUEIREDO, L.A.: A Indústria de Prestação de Serviços Logísticos e o Modelo de Negócio ASP: perspectivas e tendências no mercado brasileiro, Tese de Doutoramento, Universidade Federal de Santa Catarina, Engenharia de Produção e Sistemas, Florianópolis, outubro de 2005 .

FLEURY, P.F.; WANKE, P.; FIGUEIREDO, K.F. (org.): Logística Empresarial: a perspectiva brasileira, São Paulo: Editora Atlas, 2000.

FLEURY, P.F.; RIBEIRO, A.: “A indústria de operadores logísticos no exterior”, <http://www.centrodelogistica.com.br>, 2001a. Acesso em: 20 de maio de 2007.

FLEURY, P.F.; RIBEIRO, A.: “A Indústria de Prestadores de Serviços logísticos no Brasil: caracterizando os principais operadores", Encontro Anual da ANPAD, 27, Campinas, 2001b.

FLEURY, P.F.: "Gestão Estratégica do Transporte", <http://www.centrodelogistica.com.br>, 2002. Acesso em: 20 de maio de 2007.

GAO, L.; QI, E.: "Study on Cooperative Logistic Information System According to Supply Chain Management", Automation and Logistics, IEEE International Conference, p. 2576 2579,2007

GHOSHAL, S.E.; GRATTON, L.: "Integrating the Enterprise", MIT Sloan Management Review, v. 44, no 1, p. $31-38$, fall 2002.

GRAHAM, G.; HARDAKER, G.: "Supply Chain Management across the Internet", International Journal of Physical Distribution \& Logistics Management, v. 30, nº 3/4, p. 286 295, MCB University Press, 2000.

GUNASEKARAN, A.; NGAI, E.W.T.: "Supply Chain Management: Theory and Applications Information Systems in Supply Chain Integration and Management", European Journal of Operational Research, vol. 159, nº 2, p. 269 - 295, 2004. 
GUNASEKARAN, A.; NGAI E.W.T.: "Information Systems in Supply Chain Integration and Management", European Journal of Operational Research, v. 39, n' 2, p. 269 - 295, November 2003.

HAMMER, M.: “Reenginnering Work: don't automate, obliterate”, Harvard Business Review, Boston, July 1990.

HARTLEY, J.F.: "Case Studies in Organizational Research", Qualitative methods in organizational research: a practical guide, Sage: Editora London, p. 208- 229, 1994.

HENDERSON, J.C.; VENKATRAMAN, N.: "Strategic Alignment: leveraging information technology for transforming organization”, IBM Systems Journal. V. 32, nº 1, p. 4 - 16, 1993.

HERTZ, S.; ALFREDSON, M.: "Strategic Development of Third Party Logistics Providers", Industrial Marketing Management, v.32, p. 139 - 149, 2003.

HUMPHREY, J.; SCHMITZ, H.: "How Does Insertion in Global Value Chains Affect Upgrading in Industrial Clusters?" Institute of Development Studies, University of Sussex, Brighton, United Kingdon, 2000.

IVERSENA, J.; NGWENYAMAB, O.: "Problems in measuring effectiveness in Software Process Improvement: a Longitudinal Study of Organizational", Internationl Journal of Information Technology, vol. 26, nº 1, p. $30-43,2006$.

KANAKAMEDALA, K.; RAMSDELL, G.; SRIVATSAN, V.: "Getting Supply Chain Software Right”, The Mckinsey Quartely, n 1, p. 78 - 85, 2003.

KLAUS, H. ROSEMANN, M.; GABLE, G.G.: "What is ERP?", Information Systems Frontiers, v. 2, no. 2, p. $141-162,2000$.

KLEPPNER, D.: "Beyond Discovery: the Global Positioning System" Nacional Academy of Sciences, < http://www.beyonddiscovery.org/content/view.article.asp?a=458>, 1997. Acesso em 10 de abril de 2008.

LAI, F.; ZHAO, X.; WAN, Q.: "Taxonomy of Information Techonology Strategy and its Impacto on the Performance of Third-party Logisitcs in China", International Journal of Production Research, Vol. 45; nº 10, p. 2195 - 2218, 2007.

LA LONDE, B.; MALTZ, A.B.: "Some Propositions about Outsourcing the Logistics Function", International Journal of Logistics Management, v. 3, nº 1, p. 1 - 11, 1992. 
LAMBERT, D.M.; EMMELHAINZ, M.A.; GARDNER, J.T.: "Developing and Implementing Supply Chain Partnerships", The International Journal of Logistics Management. v. 9, n. 2, p. 1 - 17, 1996.

LAMBERT, D.M.; COOPER, M.C.; PAGH, J.D.: Supply Chain Management: implementation issues and research opportunities, The International Journal of Logistics Management, v. 9, n. 8, p. 1 - 19, Florida, 1998.

LAMBERT, D.M.; STOCK, J.R.; ELLRAM, L.M.: Fundamentals of Logistics Management, London: IRWIN McGraw-Hill, 1998.

LAMBERT, M.D.; GARCIA-DASTUGUE, S.; CROXTON K.L.: “An Evaluation of ProcessOriented Supply Chain Management Frameworks”, Journal of Business Logistics, v. 26, n. 1, p. $25-51,2005$.

LANGLEY. C.J.; ALLEN, G.R.; TYNDALL, G.R.: “Third-Party Logistics Study Results and Findings of the 2002”, Seventh Annual Study, <http://www.ryder.com/pdf/b_3pl_2002_survey.pdf>, 2003. Acesso em: 02 de julho de 2005.

LAUDON, K.C.; LAUDON, J.P.: Management Information Systems: managing the digital firm. New Jersey: Prentice Hall, $8^{\mathrm{a}}$ edição, 2004.

LAURINDO, F.J.B.: Tecnologia da Informação: eficácia nas organizações, São Paulo: Editora Futura, 2002.

LAURINDO, F.J.B.; CARAVALHO, M.M.; SCHNECK, P.P.; SHIMIZO, T.: Selecionando uma Aplicação de Tecnologia da Informação com Enfoque na Eficácia: um estudo de casos de um sistema para PCP, São Carlos: Gestão \& Produção, v. 9, no 3, dezembro de 2002. <http://www.scielo.br/scielo.php?pid=S0104-530X2002000300011\&script=sci_arttext>, Acesso em 5 de fevereiro de 2008.

LAURINDO, F.J.B.; MESQUITA, M.A.: "Material Requirements Planning: 25 anos de História - Uma Revisão do Passado e Prospecção do Futuro". São Carlos: Gestão \& Produção, v.7, n³, dezembro de 2000. <http://www.scielo.br/scielo.php?pid=S0104530X2000000300009\&script=sci_arttext $>$. Acesso em 5 de fevereiro de 2008.

LEWIS, I.; TALALAYEVSKY, A.: "Third-Part Logistics: leveraging information technology", Journal of business logistics, v. 21, nº 2, p. 173 - 185, 2000.

LIMA, M. P.: “O Custeio do Transporte Rodoviário", <http://www.centrodelogistica.com.br>, 2004. Acesso em: 23 de maio de 2007. 
LIEB, R.: What's the Future for Third-party Logistics? Supply Chain Management Review, v. $2, \mathrm{n}^{\circ} 1$, p. $71-79,1998$.

LIEB, R.; BENTZ, B.A.: "The Use of Third-Party Logistics Services by Large American Manufactures: the 2004 survey", Transportation Journal, v. 44, n 2, 2005.

LUNDBERG, H.; SCHÖNSTRÖM, M.: "Segmentation of the Third Party Logistics Market: basead on logistical requirements", Thesis no 2001:25, School of Economics and Comercial Law, Göteborg University, 2001.

MALONI, M.J.; CARTER, C.R.: "Opportunities for research in third-party logistics", Transportation Journal, v. 45, n 2, p. 23 - 28, 2006.

MARKIDES C.C.: “A dynamic view of strategy”, Sloan Management Review, v. 40, n 3, p. 55 - 63, Spring 1999.

MATTAR, F. N.: Pesquisa de Marketing, São Paulo: Editora Atlas, 1996.

MCFARLAN, W.E.: "Information technology changes the way you compete", Harvard Business Review, v. 62, n 3, p. 98 - 103, May/June 1984.

MENTZER, J.T.; DEWITT, W.; KEEBLER, J.; MIN, S.: "Defining Supply Chain Management". Journal of business Logistics. v. 22, nº 2, p. 1- 25, 2001.

MENTZER, J.T.; MIN, S.; BOBBITT, M.: "Toward a Unified Theory of Logistics", International Journal of Physical Distribution \& Logistics Management, vol. 34, $\mathrm{n}^{\circ}$ 8, p. 606 $-627,2004$.

MIGUEL, P.A.C.: "Estudo de Caso na Engenharia de Produção: Estruturação e Recomendações para sua Condução" São Paulo: Produção, v.17, nº 1, p. 216 - 229, jan/abr 2007.

MINISTÉRIO DO DESENVOLVIMENTO, INDÚSTRIA E COMÉRCIO EXTERIOR: <http://www.aprendendoaexportar.com.br>, 2007. Acesso em: 2 de dezembro de 2007.

MINTZBERG, H.; AHLSTRAND, B.; LAMPEL, J.: Safári de Estratégia: um roteiro pela selva do planejamento estratégico, Porto Alegre: Bookman, 2000.

NARASIMHAN, R.; KIM, S.W.: "Information System Utilization Strategy for Supply Chain Integration”, Journal of business logistics; v. 22, nº 2, p. 51 - 75, 2001. 
NAZÁRIO, P.: "A Importância de Sistemas de Informação para a Competitividade Logística", COOPEAD, Rio de Janeiro, <http://www.centrodelogística.com.br>, 2004. Acesso em 10 de Janeiro de 2005.

NAZARIO, P.; ABRAHÃO, F.A.: Terceirização Estruturada: o uso do RFI - Request for Information - como ferramenta de seleção de operadores logísticos, COOPEAD, Rio de Janeiro, <http://www.centrodelogística.com.br>, 2002. Acesso em 15 de janeiro de 2005.

NEELANKAVIL, F.: Computer Simulation and Modeling, John Wily \& Sons, Great Britain, 1987.

NOLAN, R.L.: "Managing the Crises in Data Processing", Harvard Business Review, v. 57, no 2, p. 115 - 126, Mar/Apr, 1979.

NOLAN, R.L.; MCFARLAN, W.E.: "Information Technology and the Board of Directors", Harvard Business Review, v. 83, nº 10, p. 96 - 106, October, 2005.

NOVAES, A.G.; DETONI, M.M.L.: "ASP: the Fourth-Party Counterparts in the Evolving Logistics Industry" 3rd IFIP Working Conference on Infrastructures for Virtual Enterprises, Portugal, 2002.

O`BRIEN, J.A.: Sistemas de Informação e as Decisões Gerenciais na Era da Internet. São Pualo: Editora Saraiva, 1ª edição, 2002.

PATTON, E.; APPELBAUM, S.H.: The Case for Case Studies in Management Research, Management Research News, v. 26, n. 5, 60-71, 2003.

PERSSON, G.; VIRUM, H.: "Growth Strategies for Logistics Service Providers: a case study". International Journal of Logistics Managemen, v. 12, nº 1, p. 53 - 64, 2001.

PORTER, M.E.: "How Competitive Forces Shape Strategy", Harvard Business Review, v. 57, n 2 , p. 137- 145, Nov/Dec 1979.

PORTER, M.E.: “What Is Strategy?”, Harvard Business Review, p. 61- 78, Nov/Dec 1996.

PORTER, M.E.: “Competição: estratégias competitivas essenciais”, Harvard Business Review Book, $5^{\text {a }}$ edição, p. 27 - 45, São Paulo: Editora Campus, 1999.

PORTER, M.E.: “Strategy and the Internet”, Harvard Business Review, p. 63 - 78, Mar 2001. PORTER, M.E.; MILLAR, V.E.: "How Information Gives you Competitive Advantage", Harvard Business Review, v. 63, n. 4, p. 149 - 160, Jul./Aug 1985. 
PESSÔA, M.S.P.; NOGUEIRA, R.: Gestão do Conhecimento como Integrador de Soluções ERP em Ambiente de Produção, Fortaleza: XXVI ENEGEP, <http://www.abepro.org.br/biblioteca/ENEGEP2006_TR530353_8185.pdf>, outubro de 2006. Acesso em: 2 de fevereiro de 2008.

RAHMAN, Z.: "Internet Based Supply Chain Management: using the Internet to revolutionize your business", International Journal of Information Management, Elsevier, v. 23, p. $493-505,2003$.

RAINBIRD M.: "Demand and Supply Chains: the value catalyst", International Journal of Phisical Distribution and Logistics Management, v. 34, nº 3/4, p. 230 - 250, 2004.

RAYPORT, J.F.; SVIOKLA J.J.: "Exploiting the virtual value chain", Harvard Business Review, p. 75 - 85, Nov/Dec 1995.

REICHERT, M.; DADAM, P.: "A Framework for Dynamic Changes in Workflow Management Systems", 8th Internacional Conference on Database and Expert Systems Applications (DEXA-97), Toulouse, France, 1997.

REYES, P.M.; RAISINGHANI, M.S.; SINGH, M.: "Global Supply Chain Management in the Telecommunications Industry: the role of Information Technology in integration of supply chain entities", Journal of Global Information Technology Management, v. 5, nº. 2, p. 48 67, 2002.

ROCKART, J.F.: "Chief Executives Define their Own Data Needs", Harvard Business Review, v. 57, nº 2, p. 81- 92, Mar/Apr 1979.

RUTNER, S.; LANGLEY JR, C.J.: "Logistics Value: definition, process and measurement", International Journal of Logistics Management; v. 11, $\mathrm{n}^{\mathrm{o}}$ 2; p. 73 - 82, 2000.

SAUVAGE, T.: “Technological Potential of Logistics Service Providers and Relationship Dynamics", Document de recherche no 2002-01, Laboratoire Orleanais de Gestion, Faculté de Droit d'Economie et de Gestion, 2002.

SEKARAN, U.: Research Methods for Managers: a skill-building approach, New York: Wiley and Sons, 1984.

SELLTIZ, C.: Métodos de Pesquisa nas Relações Sociais, São Paulo: Editora Pedagógica e Universitária, 1974. 
SHORE, B.: "Information Sharing in Global Supply Chain Systems", Journal of Global Information Technology Management, v. 4, nº 3, p. 27 - 35, 2001.

SIMATUPANG, T.M.; SRIDHARAN, R.: "The Collaborative Supply Chain: a Scheme for Information Sharing and Incentive Alignment", International Journal of Logistics Management, vol. 8, nº 3, p. 289 - 308, 2002.

SINK, H.L.; LANGLEY, J.C.: "A Managerial Framework for the Acquisition of Third-Party Logistics Services", Journal of Business Logistics, Oak Brooks, v. 18, n. 2, p. 163 - 189, 1997.

SKJOTT-LARSEN, T.: "Developing Logistics Competencies through Third Party Logistics Relationships", International Journal of Operations \& Production Management, v. 24, n. 2, 2004.

SLACK, N.: Administração da Produção, São Paulo: Editora Atlas, 1997.

SPENS, K.M.; BASK, A.H.: "Developing a Framework for Supply Chain Management", International Journal of Logistics Management, v.13, nº 1, p. 73 - 88, 2002.

STANK, T.P.; KELLER, S.B.; CLOSS, D.J.: "Performance Benefits of Supply Chain Logistical Integration", Transportation Journal, v. 41, nº. 2/3, p. 32 - 46, 2001.

STEVENS, G.C.: "Integration of the Supply Chain", International Journal of Physical Distribution and Logistics Management, v. 19, nº 8, p. 3 - 8, 1989.

SWAMINATHAN, J. M.; SMITH, S. F.; SADEH, N.M.: "Modeling Supply Chain Dynamics: a multiagent approach", Decision Sciences, v. 29, n 3, p. 607 - 632, Atlanta, USA, 1998.

SZUPROWICZ, B.O.: "Implementing Enterprise Portals: Integration Strategies for Intranet, Extranet, and Internet Resources" (Paperback), Computer Technology Research Corp., Charleston, SC, 2000.

TRIVINÕS, A.N.S.: Introdução à pesquisa em ciências sociais: a pesquisa qualitativa em educação (o positivismo, a fenomenologia, e o marxismo), São Paulo: Editora Atlas, 1987.

TURBAN E.; REINER R.K.; POTTER R.E.: Administração de Tecnologia da Informação: teoria e prática. $4^{\mathrm{a}}$ edição, Rio de Janeiro: Editora Elvesier, 2003.

TURBAN, E.; LEE, J.; KING, D.; CHUNG, M.: Electronic Commerce: a managerial perspective; $2^{\mathrm{a}}$ edição, New Jersey: Pearson Education, 2002. 
VANHARANTA, H.; BREITE, R.: "Formulating of the Supply Chain Management Method in the Internet Environment: a view of point of decision support", Human \& organizational issues in the digital enterprise, HAAMAHA 9th International Conference, Human aspects of advanced manufacturing: agility and hybrid automation, p. 302 - 313, Galway, Ireland, 2004. VASCONCELOS, M.C.R.L.; NASCIMENTO, R.M.E.: "Estratégia de Relacionamento entre os Membros da Cadeia Produtiva no Brasil: reflexões sobre o tema", Revista Gestão e Produção, v.12, nº.3, p.393 - 404, set/dez 2005.

VENKATRAMAN, N.: "IT Enabled Business Transformation: from automation to business scope redefinition", Sloan Management Review, Winter 1994.

VENKATRAMAN, N.; HENDERSON, J.C.: "Real Strategy for Virtual Organization”, Sloan Management Review, v. 40, nº. 1, p 33 - 48, Fall 1998.

VILLELA, T.M.A; LIMA JR, O.F.: "Identificação de Atributos para a Análise do Desempenho de Redes Logísticas no Setor de Serviços” Fortaleza: XXVI Encontro Nacional de Engenharia de Produção (ENEGEP), <http://www.abepro.org.br/biblioteca/ENEGEP2006_TR450302_8658.pdf>, Acesso em 20/04/2008.

WALKER R.J.; MURPHY, G.C.; FREEMAN-BENSON, B.; WRIGHT, D.; SWANSON, D.; ISAAK, J.: Visualizing Dynamic Software System Information through High-level Models in Proceedings of the Conference on Object-Oriented Programming Systems, Languages, and Applications (OOPSLA), p. 271-283, Vancouver, BC, New York, NY: ACM Press, $<$ http://citesser.ist.psu.edu/walker98visualizing.htm>, 1998. Acesso em: 30 de Janeiro de 2004.

WANGA, E.T.G.; LINA, C.C.; JIANBG, J.J.; KLEINC, G.: "Improving Enterprise Resource Planning (ERP) Fit to Organizational Process Through Knowledge Transfer", International Journal of Information Management, vol. 27, nº 3, p. 200 - 212, 2007.

WANKE, P.: “Aspectos Econômicos e Tecnológicos das Cadeias de Suprimentos e suas Implicações Gerenciais", COPPEAD, Rio de Janeiro, <http://www.centrodelogistica.com.br>, 2003. Acesso em: 15 de julho de 2005.

WANKE, P.: "Uma Revisão dos Programas de Resposta Rápida: ECR, CRP, VMI, CPFR, JIT II", COPPEAD, Rio de Janeiro, <http://www.centrodelogistica.com.br>, 2004. Acesso em: 15 de julho de 2005 . 
WEILL, P.; SUBRAMANI M.; BROADBENT M.: "Building IT Infrastructure for Strategic Agility”, MIT Sloan Management Review, v. 44, n. 1, Fall 2002.

WELTY, C.: "DLs for DLs: description logics for Digital Libraries". International Workshop for Description Logics, Trento, Itália, 1998, <http://citeseer.ist.psu.edu/17297.html>. Acesso em: 10 de maio de 2005.

WILLIAMS, L.L., NIBBS, A.; IRBY, D.: "Logistics Integration: the effect of information technology, team composition, and corporate competitive positioning", Journal of Business Logistics, v.18, nº. 2, p. $31-41,1997$.

WHITEA, A.; DANIELB E.M.; MOHDZAINC M.: "The Role of Emergente Information Techonologies and Systems in Enabling Supply Chain Agility", International Journal of Information Management, vol. 25. n 5, p. 396 - 410, 2005.

YIN, R.K.: "Case Study Research: design and methods", $2^{\text {nd }}$ edition, Sage: Thousand Oaks, CA, EUA, 1994. 


\begin{abstract}
APÊNDICE 1
Artigo publicado na Third International Conference on Production Research Americas'

Region 2006
\end{abstract}

The strategic use of IT in an international logistics company

\author{
Regina Meyer Branski \\ Instituto de Economia, University of Campinas; Production Engineering Dept. Polytechnic \\ Engineering School, University of São Paulo - branski@eco.unicamp.br
}

\title{
Fernando José Barbin Laurindo, Associate Professor
}

Production Engineering Dept.Polytechnic Engineering School, University of São Paulo fjblau@usp.br

\begin{abstract}
Since the early 1980's, the corporate approach to logistics has changed. A growing number of companies has moved on to conceive logistics not merely as an operational activity, as a costs center, but, rather, as a strategic activity, a potential source of competitive advantage. Logistics conceived as a strategic weapon results from a combination of its growing complexity with an intensive use of information technologies (IT). Technology affords the possibility of devising an optimal project for a logistics system and to provide an integrated and efficient management of its several components. The purpose of this paper is to investigate, through a case study, how IT has contributed to the performance of a Brazilian company doing business as an international logistics operator and, specifically, how this company has been resorting to IT so as to obtain a strategic and innovative position, and to increase its market share. The results obtained in this study offer to logistics operators information on technology applicable to their businesses and on how to manage and exploit them adequately and put them to strategic use.
\end{abstract}

Keywords: Information technology, logistic, logistics operators, strategy 


\section{Introduction and purposes}

Since the early 1980's, a growing number of companies has come to consider logistics as a strategic activity (Fleury, 2000). An intensive use of information technologies (IT) ensures an optimal tuning of the logistics system and an integrated management of its several components. In this new scenario, organizations in all industries are outsourcing their logistics operations to specialized companies.

The purpose of this paper is to investigate, through a case study, how IT has contributed to the good performance of a Brazilian company - here named " $\mathrm{A}$ " - that conducts business as an international logistics operator, and, specially, how company A is using IT to secure an innovative strategic position and to increase its market share. Initially, several concepts are involved in this discussion: strategy, value chain, IT and logistics. Thereafter, the case study will be presented.

\section{Theoretical framework}

\subsection{Strategy}

Strategy involves planning and performance over time, and in a consistent manner, of an action plan that will bring competitive advantages to the business (Carvalho \& Laurindo, 2003). A company acquires competitive advantages when it performs better than its competitors and is able to retain this advantage over time (Porter, 1996).

Porter (1996) classifies competitive advantages as being associated to:

- Cost: a company produces at a lower cost than its competitors

- Differentiation: a company provides greater value to customers.

Cost and product differentiation are the basic components of competitive advantage. They reflect the manner whereby all the activities the company carries out are performed. Performing activities in a manner that is more efficient than that of competitors ensures cost advantages to the company. Differentiation, in turn, is the result of a selection of the activities and of the form in which they are carried out.

An important concept for analyzing how activities affect costs and the value delivered to buyers is the value chain. It shows how a company can create competitive advantages and retain them over time. 


\subsection{Value chain}

A value chain is a structure that describes the several activities required for processing and sending the products or services to the final client. Each activity is a value activity (Porter \& Millar, 1985).

The value generated by the company is measured by the price that buyers are willing to pay for products or services. In order to ensure profit, this value must exceed the cost of performing the activities required to process the product.

The authors emphasize the links existing between the several value activities. These links become evident when a form of performing an activity affects the costs or the performance of the other activities and are important in securing competitive advantages.

The logistics function acts on the links with the purpose of setting an appropriate flow of materials and finished products among the several activities. IT provides efficient integration and coordination mechanisms. Therefore, logistics and IT are important elements in ensuring competitive advantages to a company.

\subsection{Logistics}

Logistics plans, implements and controls the flows and inventories of raw materials, products in process and finished products, services and information, from origin and up to final consumption (Rutner \& Langley, 2000).

Logistics link the company to its suppliers and to its customers. The relationships existing between the activities and their logical connections are known as "cycles of logistic activities'.

The structure of these cycles provides the logics for combining all logistic elements, and is the basis for implementing integrated logistics. Integrated logistics is the management of flows and inventories as a process, giving utmost priority to the efficiency of the chain considered as a whole (Bowersox \& Closs, 2001).

The supply or entry logistics cycle (Figure 1) serves the purpose of ensuring stable and continuous production conditions. It begins with the selection of sources of supplies, followed by the placing of the order and expedition, transportation and receipt. 


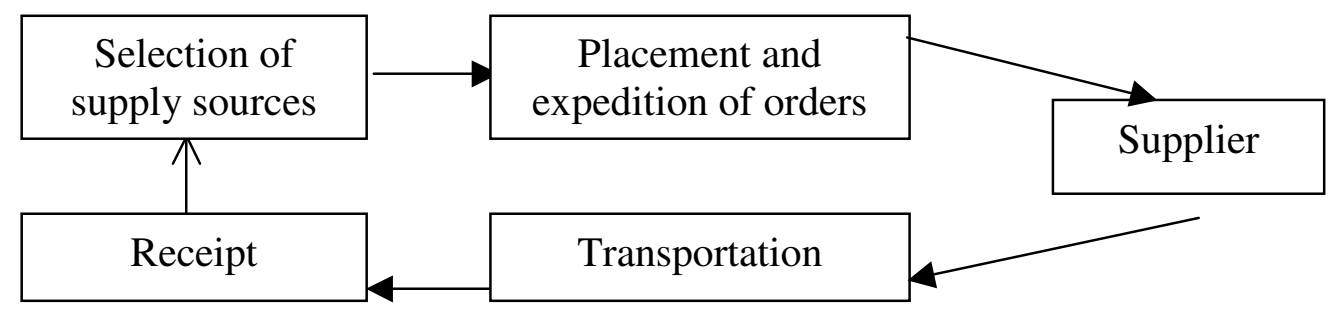

Figure 1: Activities of the supply cycle/Bowersox \& Closs (2001:59)

The physical distribution or exit logistics cycle (Figure 2) intends to make the products available to the clients. This includes the processing of client orders and the delivery of the goods. The following activities are involved: transmission, processing and sorting of orders, transportation of goods and delivery to the client.

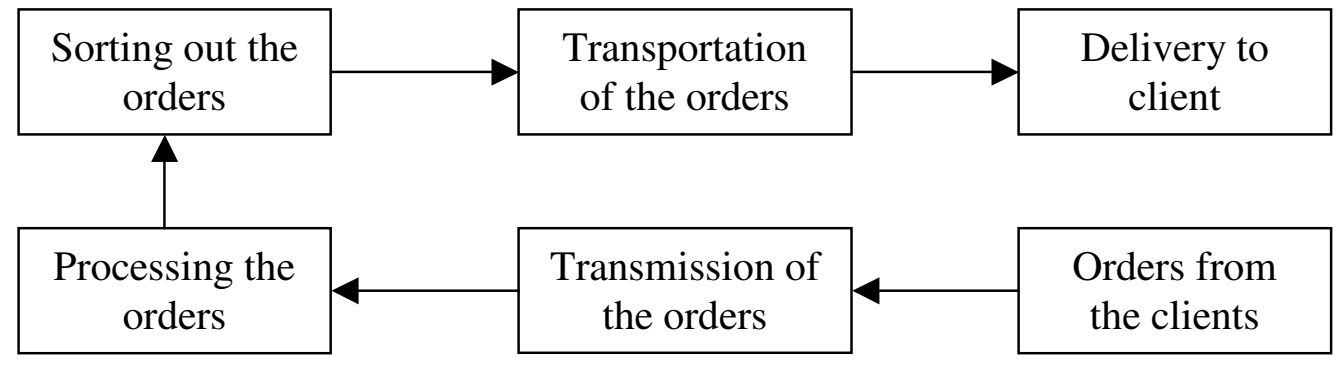

Figure 2: Activities of physical distribution cycle/Bowersox \& Closs (2001:57)

Logistics activities make use of and generate large volumes of information to be processed and transmitted to the partners. At this point, IT plays a strategic role.

\subsection{Information Technology}

The IT concept covers a vast range of convergent and related technologies that process the information generated and used by companies. Thus, "it involves not only computers, but also data recognition equipment, communication technologies, factory automation and other modes of hardware and services" (Porter, 1999).

IT establishes the links that make it possible to integrate the business processes beyond the boundaries of the company. It provides efficient mechanisms for coordinating 
several organizations, allowing partner companies to operate in an integrated way, as if part of a single organization (Evans \& Wurster, 2000).

Some of the information technologies applied to logistics are presented in the table 1. An information system is a collection of IT components organized for a specific purpose (Lewis \& Talalayevsky, 2000).

Table 1: Logistic information systems

\begin{tabular}{|c|c|}
\hline Technology & Function \\
\hline $\begin{array}{l}\text { Warehouse } \\
\text { Management System } \\
\text { (WMS) }\end{array}$ & $\begin{array}{l}\text { Controls and traces the movement of the inventories in the } \\
\text { warehouses, from reception to expedition. Checks availabilities } \\
\text { and records exit when an order is carried out. Manages the use of } \\
\text { space and labor. }\end{array}$ \\
\hline $\begin{array}{c}\text { Radiofrequency } \\
\text { Identification (RFID) }\end{array}$ & $\begin{array}{l}\text { Allows wireless communication for data reading and } \\
\text { transmission. Controls the positioning of products in the chain, } \\
\text { with the use of traceable labels. }\end{array}$ \\
\hline Fleet Tracing & $\begin{array}{l}\text { Locates immediately movable assets by mans of satellite or cell- } \\
\text { phone based technology. }\end{array}$ \\
\hline Bar Code & $\begin{array}{l}\text { Identifies products by means of a standardized system which } \\
\text { facilitates data collection. }\end{array}$ \\
\hline $\begin{array}{c}\text { Electronic Data } \\
\text { Interchange (EDI) }\end{array}$ & Electronic transmission of documents. \\
\hline $\begin{array}{l}\text { Vendor Managed } \\
\text { Inventory (VMI) }\end{array}$ & $\begin{array}{l}\text { Allows vendors to control client product needs, thus ensuring } \\
\text { remittances in the appropriate amounts and time limits. When the } \\
\text { inventory attains a pre-determined level, this system will } \\
\text { automatically generate an order. }\end{array}$ \\
\hline $\begin{array}{l}\text { Tracing/Tracking } \\
\text { System }\end{array}$ & $\begin{array}{l}\text { Clients can check the status of procedures, major information, } \\
\text { track their orders and verify possible problems. }\end{array}$ \\
\hline E-procurement & chase proced \\
\hline
\end{tabular}

Porter (2001) claims that IT can generate competitive advantages in three different manners:

- Offering new ways of overcoming competitor performance

- Creating new businesses

- Changing the structure of an industry and, consequently, competition patterns. 
The structure of an industry is defined "by five competitive forces: the power of the buyers, the power of the suppliers, the threat represented by new competitors, the threat represented by substitute products and the rivalry among the current competitors." (Porter,1999:95).

The five forces, when combined, define how economic value is divided between companies of a given industry, on one hand, and, on the other, consumers, suppliers, distributors, substitutes and new entrants. IT can alter the structure of a given sector since it is capable of modifying the relations between these five forces (McFarlan, 1984).

Bowersox \& Daugherty (1995) discuss the relations that exist among the strategic positioning of a company, its goals, its internal and external organizational structures, and the role of IT.

When a company's strategy is to reduce costs and attract a price sensitive market sector, it will attempt to achieve the best result possible with the resources available. As a rule, such companies will present a centralized structure and resort to a variety of suppliers so as to ensure, from the resulting competition, the flow of supplies at the lowest price. The role played by IT in this strategy is to provide the required support.

When a company's strategy is to add as much value as possible, it will search for quality and will strive to differentiate its products, carrying out its activities better than its competitors do. As a rule, such companies adopt moderate centralization and formalization procedures, and establish long term relationships based on mutual cooperation and on the sharing of information with selected partners. Here the role played by IT is intrinsically strategic.

Finally, the authors discuss companies whose strategy is to adapt to varying conditions and to exploit new opportunities. This option calls for a flexible approach, since a flexible company will have a greater potential to create new products or services for its clients.

Such companies generally adopt a decentralized structure and a low level of formalization. Externally, they develop long term cooperative relationships. Their strategic alliances aim at maximizing their ability to respond to market variations and to consumer demands. The role of IT is strategic.

\subsection{Logistics operators}

Many companies have adopted the strategy to outsource their logistic operations. A logistics operator is a services provider that conducts logistic activities for other companies. Logistics operators conduct part of the activities that represent the entry and exit logistics of 
the Porter \& Millar (1985) value chain, or their equivalents, viz. the physical supply and distribution cycles described by Bowersox \& Closs (2001). They do not take part in the internal activities of companies.

The relevant activities can be combined in a number of different manners. The several combinations result in a given cost and in a given service level. Efficient logistics operators are those able to provide rapid response, variance and minimum inventories, consolidation of movements, flexibility, quality and differentiation (Bowersox \& Closs, 2001).

Outsourcing of logistics requires an intense exchange of information and mutual reliance between the partners (Bolumole, 2001). Outsourced companies must be able to obtain and process information in an efficient manner, and here IT plays a central role.

\section{Case study}

Case study is an important tool to evaluate the uses of IT, since this is a dynamic but as yet little explored field of knowledge. Its conclusions, however, cannot be generalized (Claver et al, 2000; Yin, 1994). The company selected for this study is active in the logistics business and has undergone important changes as a result of its use of IT.

\subsection{Company "A"}

"A" is a Brazilian company operating in international logistics. Over the last five years, it has grown at an average rate of $20 \%$ a year, against an average market growth of only $5 \%$. It has 340 employees stationed in 12 offices throughout Brazil. The company is capable of offering a fully computer-based integrated logistic service.

When it was first organized in 1987, it operated solely as a custom's broker. As such, its activities were limited to preparing documents and performing the bureaucratic procedures required for importation and exportation transactions.

In 1990, it began to operate as an international freight forwarder, contracting space in vessels and aircraft for the purpose of sending and receiving goods. In order to ensure the feasibility of this new activity, it set up partnerships with other agents in several countries. Nevertheless, they did not represent a network, each operating in isolation.

In 1991, "A" established an exclusive partnership with a major international logistics operator - company "B" - which controls 1,000 business points spread over 168 countries. At this point, "A" became a part of a wide and well structure network of operators, with a 
worldwide scope of action. In 1994, it set up a land carrier company and several warehouses. Its strategy to expand its scope of business is evident.

Despite a strong interaction among the several activities of "A", they were performed in an isolated way, and were therefore inconsistent with the concept of logistics. Computers were used only to operate the software "A" purchased on the market in support of the importation and exportation process.

The role of IT in the company began to change in 1995, when a major telecom client demanded that its service providers integrate their work in its corporate system. "A" had to link in to the private network of this client in order to receive and send information. The exchange of information in these proprietary systems required the use of networked terminals and the adoption of the Electronic Data Interchange (EDI) concept.

In order to adapt to this new situation "A" decided to internalize IT, and retained a specialized professional. Thereafter, the information system at "A" was developed in modules. Each module performs a specific function, always aiming at an integration of information. The first modules were: document generation, shipment management and accounting.

In 1999, the order management module was developed. This module identifies a purchase need in the client system and carries out the entire process, from placing the order with the supplier up to the delivery of the goods to the purchaser.

Finally, the supervision module was developed, encompassing all other modules and ensuring the management of the entire process. Through supervision, the client is able to access information related to its purchase or delivery order.

The Internet has been essential to the strategic positioning of " $\mathrm{A}$ ". The opening of its corporate systems, allowing clients to access the information relevant to their cases and intensifying electronic information exchange only became possible thanks to the dissemination of the Internet.

"A" is currently changing its platform to a technology fully geared to the Internet. It intends to convert its system into a tool for managing importation and exportation information, and make this tool available on the market.

\subsection{Activities, processes and value chain}

The activities conducted by "A" involve cargo consolidation, customs clearance, land, air and sea transportation, international freight, door-to-door, handling, storage, client 
purchase needs management and process administration. The company has its own fleet of trucks for land transportation, maintains warehouses at certain strategic points and has set up the entire infrastructure to export or import any product. It is therefore capacitated to offer a thorough logistics service.

The business process at " $\mathrm{A}$ " is complex and involves a large number of partners, suppliers and several services providers. Suppliers include shipping companies, airlines and carriers. It also uses the services of other logistics operators, customs brokers and warehouses.

Its clients include companies from all branches of industry, and especially major supermarket networks, pharmaceutical corporations, heavy machinery manufacturers and cosmetics. The company is also able to provide services to other customs brokers or logistics operators.

Under an export assignment, "A" manages the purchase needs and client orders, picks up the products at the source and transports them by land to the port or airport where they are to be shipped. It carries out the customs clearance procedures, retains the appropriate carrier, clears the product at destination and, finally, transports the product to the final purchaser. It can also offer storage and provide all the logistics involved in performing the tasks, thereby ensuring efficiency and speed. The clients can monitor the status of their purchases on the Internet. An importation assignment follows the same procedure.

The following figure (Figure 3) illustrates the company's value chain:

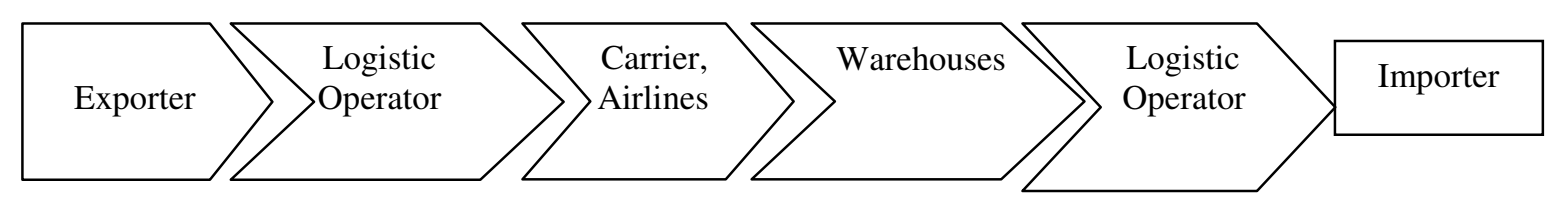

Figure 3: Value Chain of logistics operators

The fundamental concern of " $\mathrm{A}$ " is to understand the client's procedure, render it consistent with its own procedure, suggest improvements and select the IT tools required to carry out the assignment. The company takes into account the specificities of each client and attempts at designing the best solution. "A" considers flexibility to be its major differential factor. 


\subsection{Organizational structure}

The company "A" strategic policy is to offer its client a maximum of added value, total process control and the ability to adapt to different situations and needs. Consequently, its goals are differentiation and flexibility.

Its internal structure is fully integrated, decentralized and not very formal. In this way, it is able to be creative and agile in facing new situations, without being bound by unbending rules.

Its relationships with its external partners are cooperative and conceived of as longterm. Information sharing is an essential element in the conduction of its activities and its strategic alliances always seek to ensure fast adaptation to market variations and consumer demands.

The IT solutions adopted have made "A" become an agile and flexible company, allowing a speedy adaptation to different situations and requirements.

\subsection{Sector structure}

TI is strategic to the activities of logistics operators because it is able to alter all five competitive forces that make up the sector structure:

- Generate new products: logistics operator is a new business concept, made feasible by the use of IT. Furthermore, the possibility to access and format data in different manners and to articulate externally with partners, clients and suppliers represents a fertile ground for the appearance of new products in this branch of business.

- Power of suppliers and clients: although " $\mathrm{A}$ " is a small company, most of its clients and suppliers are major companies of the most varied branches. These partners usually impose solutions and standards to the other links of the chain. Therefore, "A" must have the flexibility to adapt to different needs and requirements.

- Alter the competitive bases: IT has not only reduced the cost of logistics but has also provided flexibility in its performance, thus ensuring greater efficiency and speed.

- Establish entry barriers: although the cost of the use of networks has been markedly reduced with the Internet, the command of the technology and the inter-partner tuning required in this field of business are not easily copied, a circumstance that effectively places entry barriers for new competitors. 


\subsection{Contribution of IT to strategy}

"A" considers IT to be a tool capable of differentiating its services in comparison with competitors, thus ensuring competitive advantages. In fact, there is an intense flow of information associated with its activities, in which IT plays a strategic role. The company believes it is using the most advanced technology available on the market.

IT is centrally organized within the company. The management of equipment, the decision as to which systems are to be developed and how, and the actual development of the systems are concentrated with the IT team. This team produces applications and provides support for internal and external users, as well as network and hardware maintenance services.

There is an intense use of IT, supporting the company in the performance of its internal and external activities, and allowing it to adapt to different partners and situations, besides contributing to quality and to a differentiation in the services offered.

Company "A" offers its clients several IT solutions, e.g.: network connection, external communication, radio-transmitters, access to shared data banks, managerial reports. It is often part of its clients' value chain, with an on-line follow up of the ordering and purchase management.

Table 2 below describes the strategic goals of the company and the IT applications that forward such goals. 
Table 2: Strategic goals and uses of IT

\begin{tabular}{|c|c|}
\hline Strategic goals & Uses of IT \\
\hline $\begin{array}{c}\text { Maintain a transparent relationship with its } \\
\text { partners, offering full control over } \\
\text { transactions and allowing access to updated } \\
\text { information at any time. }\end{array}$ & RFID, Tracing - Tracking System, Bar \\
Code, Fleet tracking
\end{tabular}

Although IT is a strategic tool, "A" does not possess formal mechanisms for assessing IT. Its investment policy in this field is governed by its market perception, adapting itself to client needs and seeking to coordinate IT and business strategies.

\section{Conclusions}

The goal of this paper was to investigate the role of IT in the development of the strategy of an international logistics operator. IT is central to the development of its activities and information-intensive processes, and to ensure the flexibility required to adapt to many different partners.

The strategic role of IT is clear: the adoption of the new technology generated competitive gains for the company as a consequence of its differentiation in the services offered and of the extension of its scope. IT also allows the creation of new businesses that may bring to market its importation and exportation information management system. 
Future studies should encompass a greater number of logistics operators in order to deepen the analyses presented in this paper.

\section{REFERENCES}

APPLEGATE, L \& AUSTIN, R, MCFARLAN, F, Corporate Information Strategy and Management, 6th ed. McGraw-Hill, 2003.

ASSUMPÇÃO, M.R.P. "Reflexão para a gestão tecnológica em cadeias de suprimento", Revista Gestão e Produção, v.10, n.3 p.345-361, dez. 2003.

BALLOU, R.H. Gerenciamento da cadeia de suprimentos: planejamento, organização e logística empresarial. Porto Alegre. Bookman, 4ª edição, 1999.

Berglund et al. "Third-party logistics: Is there a future?" International Journal of Logistics Management; vol. 10, n.1, pg. 59 - 62, 1999.

BOLUMOLE, Y.A. The supply chain role of third-party logistics providers, International Journal of Logistics Management; 12, 2; ABI/INFORM Global, pág. 87, 2001.

BOWERSOX, J.D. \& DAUGHERTY, P.J. Logistics paradigms: the impact of information technology. Journal of Business Logisitcs. Vol.16, nº 1, p. 65-80, 1995.

CARVALHO, M.M \& LAURINDO, F.J.B. "Estratégia para a competitividade", Editora Futura. São Paulo, 2003.

CHANDRASHEKAR, A. \& SCHARY, P.B. "Toward the Virtual Supply Chain: the convergence of IT and Organization" International Journal of Logistics Management, v.10,n.2,p.27-39, 1999.

DONOVAN, J.J. "Beyond chief information officer to network manager". Harvard Business Review, v. 66, n. 5, p. 134-140, Sept./Oct. 1988.

FLEURY, P.F. \& WANKE, P. FIGUEIREDO, K.F (org.); Logística empresarial: a perspective brasileira, Ed. Atlas, São Paulo, 2002.

HENDERSON, J.C. \& VENKATRAMAN, N. "Strategic alignment: leveraging information technology for transforming organizations”. IBM Systems Journal. V. 32, n. 1, p. 4-16, 1993.

LEWIS, I. \& TALALAYEVSKY, A. Third-part logistics: leveraging information technology. Journal of business logistics, vol.21, nº 2 pág. 173-185, 2000.

MARKIDES C. C. “A Dynamic view of strategy”. Sloan Management Review, Spring, 1999. MCFARLAN, W.F. "Information technology changes the way you compete". Harvard Business Review, v.62, n. 3, p. 98-103, May/June 1984 
NOLAN, R. L. "Managing the crises in data processing". Harvard Business Review, v. 57, n.2, p. 115-126, Mar/Apr. 1979.

PORTER, M.E. "How competitive forces shape strategy". Harvard Business Review, p. 137145, Nov/Dec, 1979.

; What is Strategy? Harvard Business Review, p.61-78, Nov-Dec, 1996

; MILLAR, V.E. "How information gives you competitive advantage". Harvard Business Review, v. 63, n. 4, p. 149-160, Jul./Aug. 1985.

."Strategy and the Internet". Harvard Business Review, p. 63-78, Mar. 2001.

ROCKART, J.F. "Chief executives define their own data needs". Harvard Business Review, v. 57, n. 2, p.81-92, Mar./Apr. 1979.

RUTNER; LANGLEY. Logistics value: definition, process and measurement. International Journal of Logistics Management;; 11, 2; pg. 73. 2000.

SHORE, B.; "Information sharing in global supply chain systems". Journal of Global Information Technology Management; v.4, n. 3; pg.27 - 35, 2001.

TURBAN E. \& REINER R.K.; POTTER R.E.; Administração de tecnologia da informação: teoria e prática., $4^{\mathrm{a}}$ edição, Rio de Janeiro, Elvesier, 2003.

TURBAN et al.; Electronic Commerce: a managerial perspective; $2^{\mathrm{a}}$ edição, Pearson Education; New Jersey, EUA, 2002.

WILLIAMS et al. "Logistics integration: the effect of TI, team composition, and corporate competitive positioning"; Journal of Business Logistics, vol.18, n.2, 1997.

YIN, R.K. "Case study research: design and methods", Applied Social Research Methods Series, Sage, EUA, 1994. 


\section{APÊNDICE 2 \\ Roteiro de Entrevista}

\section{Identificação do respondente}

\begin{tabular}{|ll}
\hline 1. & Nome: \\
\hline 2. & E-mail: \\
\hline 3. & Cargo atual: \\
\hline 4. & Formação: \\
\hline 5. & Tempo de experiência profissional: \\
\hline 6. & Tempo de experiência no cargo atual:
\end{tabular}

\section{Informações sobre a Empresa}

\begin{tabular}{|ll|}
\hline 1. & Nome: \\
\hline 2. & Ano de fundação: \\
\hline 3. & Faturamento anual \\
\hline 4. & Número total de funcionários: \\
\hline 5. & Número de funcionários da área de TI \\
\hline 6. & Quantos níveis hierárquicos existem na organização? \\
\hline 7. & Em qual nível hierárquico está o responsável pela TI na empresa? \\
\hline 8. & Unidades da empresa \\
\hline 9. & Atividades desenvolvidas em cada unidade \\
\hline 10. & Região de atuação: Brasil: Sul - Sudeste - Centro Oeste - Nordeste - Norte \\
\hline 11. & Atuação internacional: \\
\end{tabular}

\section{Histórico da empresa}

1. Pequeno histórico da empresa:

2. Origem da empresa:

3. Unidades de negócio: 
4 Estrutura ou rede logística

\begin{tabular}{|l|l|}
\hline $\begin{array}{c}\text { Armazéns ou Centros de } \\
\text { Distribuição }\end{array}$ & \\
\hline- Dedicados & \\
\hline- Compartilhados & \\
\hline Frota terrestre & \\
\hline Frota aérea & \\
\hline Frota marítima & \\
\hline
\end{tabular}

5 Clientes, parceiros e fornecedores

\begin{tabular}{|l|l|l|}
\hline \multicolumn{1}{|c|}{ Setor de atuação dos clientes } & Sim & Não \\
\hline 1. Atacado e comércio exterior & & \\
\hline 2. Varejo & & \\
\hline 3. Alimentos e bebidas & & \\
\hline 4. Eletroeletrônico & & \\
\hline 5. Farmacêutico & & \\
\hline 6. Higiene e Cosmético & & \\
\hline 7. Limpeza & & \\
\hline 8. Automotivo & & \\
\hline 9. Informática e Telecomunicação & & \\
\hline 10. Alimentos & & \\
\hline 11. Material Mecânico & & \\
\hline 12. Material elétrico & & \\
\hline 13. Química e Petroquímica & & \\
\hline 14. Plástico e borracha & & \\
\hline 15. Confecção e têxteis & & \\
\hline 16. Papel e celulose & & \\
\hline 17. Serviços & & \\
\hline 18. Siderurgia e metalurgia & & \\
\hline 19. Outros (quais?) & & \\
& & \\
\hline
\end{tabular}




\begin{tabular}{|l|l|l|}
\hline Setor de atuação dos fornecedores e parceiros & Fornecedores & Parceiros \\
\hline 1. Transporte terrestre & & \\
\hline 2. Transporte aéreo & & \\
\hline 3. Transporte marítimo & & \\
\hline 4. Transporte ferroviário & & \\
\hline 5. Courier & & \\
\hline 6. Empresas de armazenagem & & \\
\hline 7. Despachantes aduaneiros & & \\
\hline 8. Prestadores de serviços & & \\
\hline 9. Fornecimento e desenvolvimento de TI & & \\
\hline 10. Consultoria para projetos & & \\
\hline 11. Outros operadores logísticos & & \\
\hline 12. Outros (quais?) & & \\
\hline
\end{tabular}

\section{Processo logístico: fluxos de produtos e informação}

\subsection{Fluxos de materiais e produtos: atividades e tarefas desenvolvidas}

6.1.1 Descreva o fluxo logístico dos materiais e produtos executado pela empresa.

6.1.2 Existem diferenças significativas nos fluxos de materiais e produtos nos diferentes setores atendidos pela empresa? E nas diferentes empresas do mesmo setor?

6.1.3 Você atribuiria estas diferenças a quais fatores?

- Características do setor

- Posicionamento estratégico

- Políticas de produção do cliente 
6.1.4 Atividades desenvolvidas pelo operador

\begin{tabular}{|c|c|c|}
\hline A. Armazenagem, manuseio e embalagem & Sim & No futuro \\
\hline Recebimento e conferência física, quantitativa e documental & & \\
\hline Controle de qualidade na entrada & & \\
\hline Controle e responsabilidade pelas avarias & & \\
\hline Executa unitização (paletização e conteinerização) & & \\
\hline Separação e retirada dos paletes vazios & & \\
\hline Consolidação & & \\
\hline Desconsolidação & & \\
\hline Identificação dos produtos e etiquetagem & & \\
\hline Separação dos pedidos (pick) & & \\
\hline Embalagem ( pack) & & \\
\hline Montagem de kits & & \\
\hline Troca de etiquetas e manuais (nacionalização) & & \\
\hline Armazenagem seca, refrigerada ou alfandegada & & \\
\hline Transferência de produto para centros de distribuição & & \\
\hline Abastecimento de gôndolas & & \\
\hline Retirada de devoluções (logística reversa) & & \\
\hline Peças de reposição e serviços de suporte & & \\
\hline Abastecimento de gôndolas & & \\
\hline Cross docking & & \\
\hline B. Estoque & & \\
\hline $\begin{array}{l}\text { Gestão do estoque (controla quantidades, localização e valores do } \\
\text { estoque do cliente) }\end{array}$ & & \\
\hline $\begin{array}{l}\text { Apoio no estabelecimento da política de gestão dos estoques dos } \\
\text { clientes }\end{array}$ & & \\
\hline C. Transporte & & \\
\hline Transporte Rodoviário & & \\
\hline Transporte aéreo & & \\
\hline Transporte ferroviário & & \\
\hline Transporte marítimo & & \\
\hline Embarque, remessa, consolidação e realocação de carga & & \\
\hline Gerenciamento do transporte intermodal & & \\
\hline
\end{tabular}




\begin{tabular}{|c|c|c|}
\hline C. Transporte & Sim & No futuro \\
\hline \multicolumn{3}{|l|}{ Entrega just in time } \\
\hline \multicolumn{3}{|l|}{ Milk run } \\
\hline \multicolumn{3}{|l|}{ Porta a porta } \\
\hline \multicolumn{3}{|l|}{ Serviço expresso (Courier) } \\
\hline \multicolumn{3}{|c|}{ Emissão de relatório de acompanhamento do nível de serviço. } \\
\hline \multicolumn{3}{|c|}{ C.1 No caso de terceirização do serviço de transporte } \\
\hline \multicolumn{3}{|c|}{ Seleção e contratação de transportadoras } \\
\hline \multicolumn{3}{|l|}{ Negociação do serviço } \\
\hline \multicolumn{3}{|c|}{ Pesquisa periódica do valor dos fretes } \\
\hline \multicolumn{3}{|c|}{ Conferencia e realização do pagamento de fretes } \\
\hline \multicolumn{3}{|l|}{ Coordenação das transportadoras } \\
\hline \multicolumn{3}{|c|}{ Avaliação e controle do desempenho das transportadoras } \\
\hline \multicolumn{3}{|c|}{ D. Atividades de apoio á produção } \\
\hline \multicolumn{3}{|l|}{ Kanban } \\
\hline \multicolumn{3}{|c|}{ Sequenciamento e abastecimento de linhas de produção (just-in-time) } \\
\hline \multicolumn{3}{|l|}{ Preparação de kits de produção } \\
\hline \multicolumn{3}{|c|}{ Abastecimento de linha de montagem (sequenciamento) } \\
\hline \multicolumn{3}{|l|}{ E. Atuação internacional } \\
\hline \multicolumn{3}{|l|}{ Desembaraço aduaneiro } \\
\hline \multicolumn{3}{|c|}{ Operações portuárias e frete internacional } \\
\hline \multicolumn{3}{|l|}{ Armazenagem alfandegada } \\
\hline \multicolumn{3}{|c|}{ Assessoria e consultoria em comércio internacional } \\
\hline \multicolumn{3}{|l|}{ G. Serviços de informação } \\
\hline \multicolumn{3}{|l|}{ Gestão de informações logísticas } \\
\hline \multicolumn{3}{|c|}{ Planejamento e adequação da rede logística aos clientes } \\
\hline \multicolumn{3}{|c|}{ Desenvolvimento de projetos e/ou soluções logísticas } \\
\hline \multicolumn{3}{|l|}{ Coordenação das transportadoras } \\
\hline \multicolumn{3}{|c|}{ Emissão de relatórios estatísticos e gerenciais } \\
\hline \multicolumn{3}{|c|}{ Monitoramento do desempenho logístico } \\
\hline \multicolumn{3}{|l|}{ Realização de projeções } \\
\hline \multicolumn{3}{|l|}{ Estudo de viabilidade } \\
\hline Assessoria e consultoria fiscal & & \\
\hline
\end{tabular}




\section{2 - Fluxos de informação}

6.2.1 Histórico de utilização da TI na empresa

6.2.2 A empresa desenvolve sistemas customizados ou adquire no mercado?

6.2.3 Como é o processo de decisão quanto ao desenvolvimento ou compra de novos aplicativos?

6.2.4 Descrição do fluxo das informações e como é atendido pela TI

- Que processos estão cobertos pela TI na empresa?

- Quais aplicações de TI são utilizadas?

6.2.5 A TI vem contribuindo para que a empresa obtivesse:

\begin{tabular}{|l|l|l|l|}
\hline & Não & Sim & $\begin{array}{c}\text { Em } \\
\text { termos }\end{array}$ \\
\hline Redução de custos & & & \\
\hline Diferenciação dos produtos e serviços & & & \\
\hline Rapidez nos fluxos de produtos e serviços & & & \\
\hline Velocidade de resposta & & & \\
\hline Variância mínima & & & \\
\hline Estoque mínimo & & & \\
\hline Consolidação da movimentação & & & \\
\hline Flexibilidade & & & \\
\hline Qualidade & & & \\
\hline Apoio ao ciclo de vida & & & \\
\hline Ampliação da clientela & & & \\
\hline Ampliação do mercado & & \\
\hline
\end{tabular}

6.2.6 O uso da TI permitiu o desenvolvimento de novos produtos ou serviços? E de novos negócios? Quais?

6.2.7 Em sua opinião, a empresa vem contribuindo para a adoção e disseminação do uso da TI junto a seus clientes e parceiros? 


\section{Contribuição da TI para o estabelecimento de redes de valor}

Quanto à rede logística (clientes, fornecedores e parceiros):

7.1 As informações são compartilhadas entre os agentes? Qual o grau? (todos os agentes ou parte deles?). Como?

7.2 Há sincronização dos fluxos de material, produtos e informação entre os parceiros (coordenação)? Como?

7.3 Há parâmetros ou regulamentações que devem ser seguidos pelos agentes da rede, tais como codificação de materiais e produtos e/ou práticas de automação e gestão? Quem estabelece as diretrizes?

7.4 A empresa mantém parcerias de longo prazo com os agentes da rede? Quais? 